Szegedi Tudományegyetem

Természettudományi és Informatikai Kar

Földtudományok Doktori Iskola

Gazdaság- és Társadalomföldrajz Tanszék

\title{
A KLASZTERESEDÉSI FOLYAMATOK SIKERESSÉGÉNEK ÉS PROBLEMATIKÁJÁNAK VIZSGÁLATA A DÉL-ALFÖLDI RÉGIÓ PÉLDÁJÁN
}

Doktori (Ph.D.) értekezés

Berkecz-Kovács Lívia

Témavezető:

Dr. Mészáros Rezső

akadémikus egyetemi tanár, Professor Emeritus

Szeged

2019 


\section{TARTALOMJEGYZÉK}

BEVEZETÉS

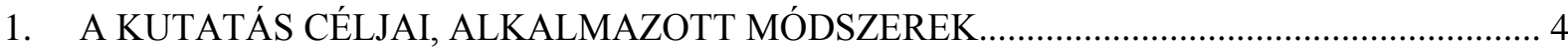

1.1. A kutatás indokoltsága, főbb céljai, hipotézisei .................................................................... 4

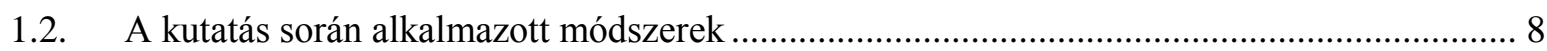

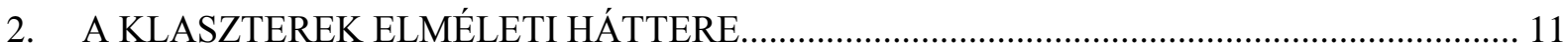

2.1. A klaszterek fogalma, csoportosítása és hozzáadott értéke ................................................ 11

2.2. A földrajzi koncentráció, kapcsolati közelség és a bizalom szerepe a klaszterekben ........... 16

2.3. Klaszterek szerepe az innovációs folyamatokban és a tudáshálózatokban ........................... 19

2.4. A klaszter együttmüködések szereplői, szervezeti háttér, szervezeti kultúra szerepe............ 23

2.5. A klaszterek sikerességének alapfeltételei, a klaszterek fenntarthatósága ............................ 26

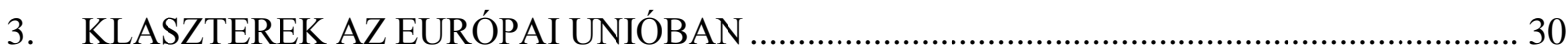

3.1. Klaszterek az Európai Unió politikáiban és támogatási rendszerében ................................... 30

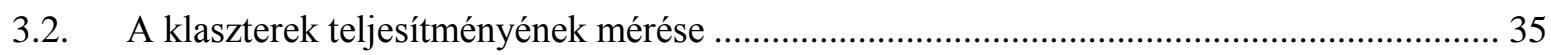

3.3. A klaszterprogramok átalakulása, új fókuszpontok kialakulása.......................................... 38

3.4. A klasztermenedzsment szervezetek szerepe és kihívásai ................................................... 40

4. KLASZTEREK MAGYARORSZÁGON ÉS A DÉL-ALFÖLDI RÉGIÓBAN ......................... 43

4.1. Klasztertámogatási rendszer Magyarországon 2000 és 2013 között.................................... 43

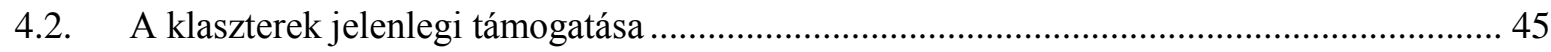

4.3. A klaszterek földrajzi jellemzöi, teljesítménye …................................................................. 49

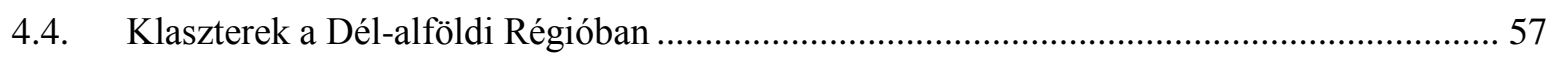

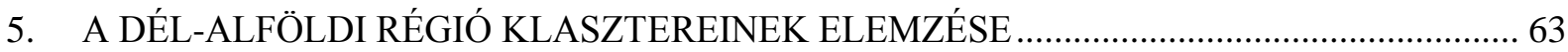

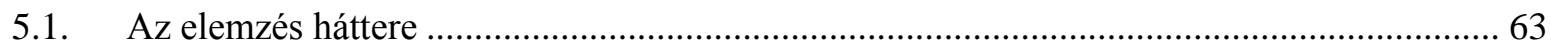

5.2. A klaszterek létrejöttének háttere, a klaszterek sikerkritériumai......................................... 67

5.3. A klaszterek hozzáadott értéke, a klaszteren belüli szolgáltatások fejlődése.......................... 73

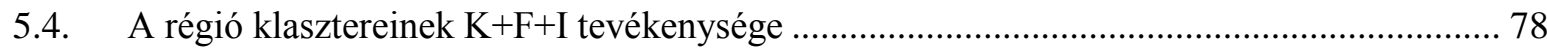

5.5. A klaszterek finanszírozása, pénzügyi és szakmai fenntarthatósága, jövőbeni fejlődése ..... 86

6. A SZOFTVERIPARI INNOVÁCIÓS PÓLUS KLASZTER SIKERESSÉGÉNEK ELEMZÉSE91

6.1. Az alapvető „,sikerkritériumok” érvényesülése a klaszterben ............................................ 92

6.2. A Szoftveripari Innovációs Pólus Klaszter hozzáadott értéke a klasztertagok számára ....... 95

6.3. $\mathrm{K}+\mathrm{F}+\mathrm{I}$ tevékenységek, tudásátadás a klaszteren belül ...................................................... 96

6.4. A klaszter pénzügyi és szakmai fenntarthatósága, jövőbeni célok, nemzetközi trendek ...... 98

6.5. Esettanulmány eredményei, legfontosabb megállapítások................................................ 100

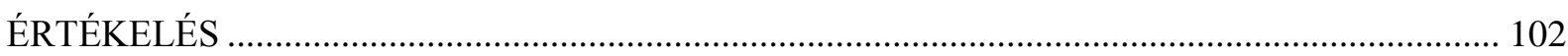

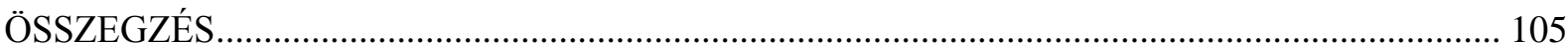

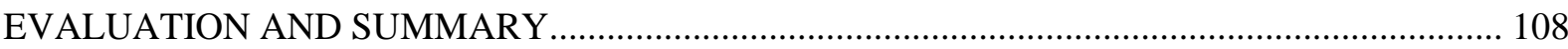

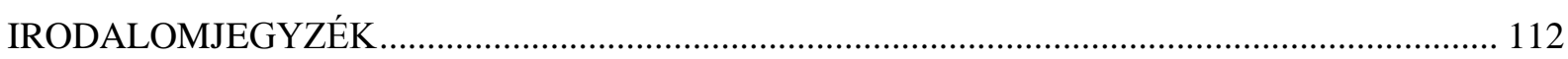

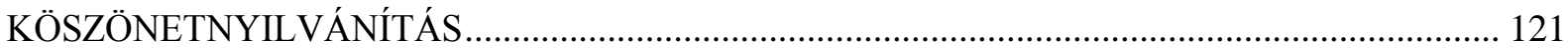

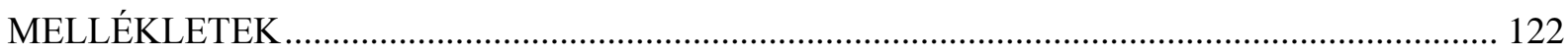




\section{BEVEZETÉS}

A klaszterekkel kapcsolatos elméleti kutatások alapjai egészen Alfred Marshallig nyúlnak vissza, aki a gazdasági területek földrajzi koncentrációjának és az iparági körzetek társadalmi és kulturális hatásainak vizsgálatával hívta fel a témára a figyelmet (Marshall, A. 1920). Azóta számos megközelítés és kutatási irány jelent meg a közgazdaságtanban és a gazdaságföldrajzban a térbeli koncentrálódás, gazdasági hálózatok, klaszterek vizsgálatával kapcsolatban. Ennek köszönhetően a klaszterek elméleti háttere rendkívül gazdag, különféle megközelítések, definíciók állnak rendelkezésünkre a neoklasszikus közgazdaságtan koncepciójától kezdve, Porter munkásságán át egészen a regionális tudományok képviselőinek álláspontjáig (PORTER, M. E 1990, Krugman, P. 1991, STORPER, M. 1995, ENRIGHT, M.J. 1996, MCCANN, P. 2008). A nézőpontok változatossága különféle csoportosításokat és sokszor szinonimaként használt megnevezéseket is magával hozott a klaszteres jellegü együttmüködésekre, úgy mint agglomerációs gazdaságok, iparági körzetek, hálózatok, növekedési pólusok, helyi termelési rendszerek (CRUZ, S.- TEXIERA, A. 2009).

Az elméleti irányzatok mellett az egyre fokozódó globális versenyben a klaszterek kitüntetett szerepét és népszerüségét olyan világszerte sikeresen müködő példák is megerősítették, mint az olaszországi iparági körzetek, a Szilícium völgy, vagy akár Baden-Würtenberg autóiparának sikere (BeCATtini, G. 1989, Longhi, C. - KeEBle, D. 2000, LENGYEL, I. 2010). Az egyes országok eltérő gazdasági, társadalmi jellemzőihez és vállalkozói kultúrájához igazodva Európa szerte is különböző típusú klaszterek alakultak ki (WISE, E. - JOHANSSON, C. 2012).

A klaszterek hozzájárulnak a vállalkozások termelékenységének javulásához, az üzleti és innovációs együttmüködések és a tudástranszfer folyamatok ösztönzéséhez, ezáltal a területfejlesztés, a regionális gazdaságfejlesztés és innovációs politikák hatékony eszközei lehetnek (Porter, M. E. - Sölvell, Ö. 1998, IsAKSEN, A. - HAuge, E. 2002, LengYel, I. 2010, KeTEls, C. et al. 2013, Delgado, M. et al. 2014).

A klasszikus értelemben vett regionális iparági klaszterek kialakulásához az egyes agglomerációs és szinergikus hatások révén egyfajta öngerjesztő és önfenntartó folyamat vezet. Természetesen ez a folyamat a gazdaságfejlesztési és vállalkozásfejlesztési politika által tudatosan ösztönözhető, illetve felgyorsítható (GROSZ, A. 2006). A klaszterorientált politikának kiemelt jelentősége van a fejlődő, illetve a periférikus térségek esetében, hiszen itt fokozottan jelentkeznek azok a negatív tényezők, amelyek hátráltatják az öngerjesztő folyamatokat és a klaszterek alulról jövő kezdeményezésként történő kialakulását (GROSZ, A. 2006). Ennek megfelelően a 2000-es évek elejétől az Európai Unió egyre nagyobb hangsúlyt fektetett a klaszterek ösztönzésére, megjelent annak innovációs politikájában és intézményi rendszerében, valamint az egyes tagországok is sorra építették be a saját területfejlesztési, regionális, gazdaságfejlesztési és innovációs szakpolitikáikba a klaszterfejlesztési intézkedéseket (HIGH LEVEL ADVISORY GROUP ON CluSTERS 2007, EURÓPAI KÖZÖSSÉGEK BIZOTTSÁGA 2008/A). Jelenleg közel 2.000 klaszter müködik az Európai Unióban, a foglalkoztatottak $38 \%$-át magában foglalva, melyböl 150 világszínvonalúnak tekinthető a foglalkoztatást, a méretet és a specializációt tekintve. A felmérések szerint a klaszterek jelenléte és müködése pozitív hatással van a foglalkoztatásra, a bérekre és az üzleti környezetre, továbbá a klaszterekbe tömörült vállalatok magasabb termelékenységet és innovációs teljesítményt értek el a nem klaszterben müködőekhez képest (KETELS, C. SERGIY, P. 2016).

A 2007-2013-as programozási időszak a Magyarországi klaszteresedési folyamatoknak is nagy lendületet adott, köszönhetően a többlépcsős klaszterfejlesztési programoknak. Ebben az időszakban kétszáz feletti nagyságrendben alakultak induló együttmüködések és a fejlődő 
klaszterek tevékenysége is számos ponton észlelhető volt a gazdaságfejlesztési és innovációs programokban. A nagy mennyiségü pályázati forrás segítségével a klaszterfejlesztési programok vezetői meg kívánták teremteni az alapját egy önfenntartó klaszteres ökoszisztéma kialakulásához és az olyan kiemelkedő növekedési és innovációs potenciállal rendelkező professzionális klaszterek megerősödéséhez, amelyek nemzetközi szintü sikereikkel hozzájárulnak az ország versenyképességéhez.

A klaszteresedési folyamatok tudatos ösztönzését követően nemzetközi szinten egyre nagyobb figyelem irányult a klaszterek hatékonyságának és sikerességének elemzésére, azok feltörekvő iparágakban betöltött szerepének vagy a klasztermenedzsment tevékenységének és jelentőségének vizsgálatára (MEIER ZU KÖCKER, G. - MÜLlER, L. 2015, IZSAK, K. et al. 2016). A 2000-es évek elejétől Magyarországon is egyre népszerübb kutatási területté vált a klaszteresedés hátterének és lehetőségeinek vizsgálata (LENGYEL, I. 2002, GROSZ, A. 2005, PATIK, R. 2007, SZANyI, M. 2008, VAS, Zs. B. 2009). Később már hazai szinten is a hatékonysági kérdések kerültek elötérbe és az elmúlt években a klaszterfejlesztési programok irányítóinak közremüködésével született néhány elemzés is, arra irányulóan, hogy a támogatások milyen rövid távú hatásokat fejtettek ki és milyen számban és területi jellemzőkkel alakultak ki a klaszterek (HoRvÁTH, M. et al. 2013, COLOSSEUM BUDAPEST KFT. 2015). Annak vizsgálatára azonban még viszonylag kevés kutatás irányult, hogy ezek a kezdeményezések mennyire tekinthetőek sikeresnek és akár további fejlesztési folyamatok eredményeként mennyiben járulhatnak hozzá a vállalkozások és a régiók versenyképességének és innovációs kapacitásának növekedéséhez. Ennek a kérdésnek a megválaszolásához kíván a dolgozatom részben hozzájárulni, azzal, hogy megpróbálja a Délalföldi Régióban müködő klaszterek sikerességét különböző szempontok szerint megközelítve értékelni és felhívni a figyelmet azokra fejlesztési területekre, amelyek a továbbiakban hozzájárulhatnak ezekhez a folyamatokhoz.

A dolgozat hat fö szerkezeti egységre tagolódik. A dolgozat első fejezete a kutatás indokoltságát, fó céljait és kérdéseit, továbbá a kutatás során alkalmazott tudományos módszertant mutatja be. Ezt követően a klaszterek kialakulásának és fejlödésének elméleti hátterét ismertetem, a klaszteres terminológia és különböző megközelítések csoportosításától kezdődően a klaszterek innovációs rendszerekben betöltött szerepén át egészen a működés, szervezeti, kulturális és finanszírozási háttér konkrét elméleti kérdéseivel bezárólag. A dolgozat harmadik fejezete az Európai Unió klasztertámogatási és minősítési rendszereiről ad áttekintést, kiemelt tekintettel az elmúlt időszakban tapasztalható kihívásokra és új fejlesztési irányokra. Ezt követően a negyedik fejezetben a hazai klaszteresedési folyamatok és klaszterfejlesztési programok fó lépéseire és számszerüsíthető eredményeire fókuszálok, a fejezet végén leszükítve azt a Dél-alföldi Régió klasztereinek jellemzőire. A dolgozat ötödik fejezetében a kvalitatív kutatásom eredményeit ismertetem a fejezet első pontjában megfogalmazott négy részkérdésnek megfelelő tematikai tagolásban. Először a régióban müködő klaszterek alapvető sikerességi kritériumait vizsgálom, majd azok hozzáadott értékét és innovációs teljesítményét igyekszem értékelni, végül a fenntarthatóság különböző szempontjait elemzem. Az értekezés utolsó fejezetében egy klaszteres esettanulmány segítségével mutatom be a klaszterek eredményességének vizsgálata mögött rejlő legfőbb kérdéseket és motívumokat. A dolgozatot végül a kutatási eredmények értékelésével és néhány javaslat megfogalmazásával, majd az összegzéssel zárom. 


\section{A KUTATÁS CÉLJAI, ALKALMAZOTT MÓDSZEREK}

\subsection{A kutatás indokoltsága, főbb céljai, hipotézisei}

Az intenzív klaszterfejlesztési programoknak köszönhetően Magyarországon több, mint 200 klaszterkezdeményezés jött létre 2007 és 2013 között, melyek nagy része a támogatási források megszünésével megrekedt az induló fázisban. Az érettebb fejlődési szakaszba jutó klaszterek közül jelenleg 26 olyan minösített (akkreditált) nemzetközi jelentőségü, magas foglalkoztatási és innovációs hatással rendelkező klaszter müködik, melyeknek nagy fejlödési potenciált tulajdonítottak a szakértők. A Dél-alföldi Régiónak kiemelkedő szerepe volt ezen folyamatokban, hiszen a 2000-es évek elejétől kezdve 51 klaszter alakult a régióban, melyből 36 regionális fejlesztési támogatásban részesült és ennek eredményeként 9 jutott el a minősítési szakaszig. A 2007-2013-as programozási időszakban rendelkezésre álló gazdaságfejlesztési és kutatás-fejlesztési pályázatokban is kiemelkedően szerepeltek a régió klaszterei, így számos közös projekttel és fejlesztéssel igyekeztek megalapozni és megszilárdítani az együttmüködéseket (HORVÁTH, M. et al. 2013, COLOSSEUM BUDAPEST KFT. 2015).

A klaszterfejlesztési programok hatására kialakult „,klaszteralapítási láz” egy viszonylag negatív megítélést is eredményezett a klaszterek fogalmával kapcsolatban, hiszen a gyorsan megalakuló klaszterek egy részét kizárólag az elérhető támogatási források motiválták és a források megszünésével eltủntek. Felmerül a kérdés, hogy a klaszteresedési folyamatok eredményeként létrejött nagyszámú együttmüködések legalább egy része hosszú távon is képes lesz-e fennmaradni és olyan gazdasági értelemben vett „csúcsklaszterekké” válni, amelyek hozzájárulnak a régió és az ország versenyképességének növekedéséhez. Ezen folyamatok hatékony támogatásához a gazdaságfejlesztési programok irányítóinak mélyebben szükséges megismerniük a klaszterek müködését és motivációit, továbbá feltárniuk azokat az erösségeket és gyengeségeket, amelyek a sikerükhöz vagy akár épp sikertelenségükhöz vezettek.

A dolgozatom fő célja a klaszteresedési folyamatok sikerességének és problematikájának vizsgálata a Dél-alföldi Régió példáján keresztül bemutatva.

Az elemzésem mintaterületének a Dél-alföldi Régiót, mint területi egységet választottam ki, hiszen ez a régió kiemelkedő teljesítményt mutatott a klaszteresedési folyamatok szempontjából és munkám során is ezen régió klasztereit volt alkalmam mélyebben megismerni, továbbá úgy vélem a fejlődési útvonalat és a legfőbb problémákat jól be lehet mutatni ezen a földrajzi léptéken keresztül.

A téma indokoltsága és a bemutatott problémafelvetés alapján a fentiek alapján a dolgozatomban arra a fö kérdésre kerestem a választ, hogy az elmúlt 10 év intenzív felülről vezérelt klaszteresedési folyamatainak hatására létrejött klaszterek sikeresnek mondhatóak-e és így hosszú távon is a régió fejlődésének meghatározó szereplőivé válhatnak.

A klaszterekkel kapcsolatos kutatásom során a régióban müködő klaszterek sikerességét a szakirodalmi háttér elemzése alapján 4 fó témakör mentén vizsgáltam a sikeresség alapfeltételeinek meglététől kezdve, a klaszteres elönyökön és az innovációs tevékenységeken túl, azok hosszú távú pénzügyi és szakmai fenntarthatóságáig. Azokat a klasztereket tekintem tehát a kutatásom szempontjából sikeresnek, amelyeknek mind a négy területen sikerült elöre lépniük és jelentős eredményeket felmutatniuk.

A kutatásom fő kérdése, tehát az alábbi négy kérdéssel egészíthető ki: 
- A támogatásoknak köszönhetően a régió klaszterei kialakították-e a sikeres müködéshez szükséges alapfeltételeket?

- A Dél-alföldi Régió klaszterei kihasználják és kamatoztatják-e a klaszteres együttműködésekből származó előnyöket és mekkora hozzáadott értéket képviselnek a klasztertagjaik számára?

- Mennyire innovatívak Dél-alföldi Régióban müködő klaszterek?

- Az elmúlt évek fejlesztései és működési tapasztalatai révén a Dél-alföldi Régióban létrejött klasztereknek sikerült-e stabil pénzügyi és szakmai növekedési pályára lépniük, így önfenntartóvá válhat-e a tevékenységük?

A fenti kérdések megválaszolása mellett a dolgozatomban igyekszem rávilágítani, hogy melyek azok a területek, amelyeken a klasztereknek változásra, további fejlesztésre, célzott külső vagy belső beavatkozásra van szükségük.

A disszertáció fő célja és kérdései alapján az alábbi hipotéziseket fogalmaztam meg:

\section{Hipotézis}

A klaszterek sikeres müködése mögött számos kulcsfontosságú tényező áll. A különböző kutatások, többféle megközelítésböl, de mégis hasonló következtetésekre jutottak ezen kulcstényezőket illetően (ANDERSSON, T. et al. 2004, IzSAK, K. et al. 2016, KETELS, C. 2017 , HoRVÁTH, M. et al. 2013). A sikeres müködés mögött azonosított kulcstényezök között is van néhány olyan alapvető fontosságú, amelyek megléte szinte minden klaszter esetében szükséges ahhoz, hogy a hosszú távú együttmüködés biztos alapokra épüljön. Kutatásomban ilyen alapfeltételeknek tekintem a földrajzi koncentrációt és specializációt, a megfelelő klaszterméretet és változatos összetételt, a tagok közötti együttműködési dinamika és kölcsönös bizalom meglétét, a közös szakmai háttér és célok kialakítását, valamint az ezt támogató professzionális menedzsment szervezetet. Magyarországon a 2007 és 2013 között zajló komplex klaszterfejlesztési program révén több, mint 200 induló és fejlődő klaszter került támogatásra közel 8 Milliárd forint felhasználásával. Ezeket a forrásokat célzottan a sikeres együttmüködések alapfeltételeinek kialakítására kapták a klaszterek, tehát a tagok bevonására, a klaszterstratégia, közös célok és szervezeti keretek kidolgozására, az egymás megismerését és a bizalom megteremtését támogató tevékenységekre, a klasztermenedzsment kialakítására, továbbá a közös tevékenységek, fejlesztések elindítására. Az így létrejött és megerösödött klaszterek nagyjából 1/4-e a Dél-alföldi Régióban található, mely az országos átlagot nézve kiemelkedőnek számít (NGM GFP HÁT Nemzetközis és Klaszter Osztály, 2014). Ezek alapján a kutatásom első hipotézisként azt a felvetést vizsgáltam meg, amely szerint:

\section{Az elmúlt évek intenzív klaszterfejlesztési támogatásainak köszönhetően a Dél-alföldi Régió klaszterei rendelkeznek a sikeres müködéshez szükséges alapfeltételekkel.}

\section{Hipotézis}

A klaszterekben megvalósuló együttmüködések minden résztvevő számára egyértelmüen definiálható előnyökkel szolgálnak, mely előnyök fenntartása és fokozása, alapvető jelentőségü a klaszterek sikerességének vizsgálatakor. A klasztertagok csak akkor lesznek hajlandóak ezekbe az együttmüködésekbe energiát és egyéb erőforrásokat fektetni, ha az hosszú távon megtérül a számukra. A klaszterek által nyújtott előnyök igen sokfélék és összetettek és akár résztvevőnként is eltérőek lehetnek. A tagok a térbeli koncentrálódás és kooperáció révén például költségmegtakarítást érhetnek el a közösen igénybevett erőforrások vagy beszerzések által, gyorsabban és könnyebben jutnak a számukra értékes piaci tudáshoz, információkhoz, továbbá a klasztertagok körében megvalósult közös fejlesztések, projektek is további értéket teremthetnek a számukra. (PORTER, M.E. 1998, COOKE, P. 2001, ENRIGHT, M. J. 2003, Delgado, M. ET AL. 2014). Ezen előnyök fokozásához a klasztermenedzsment 
szervezetek is számos tevékenyéggel és célzott szolgáltatással igyekeznek hozzájárulni. A klasztertagok számára nyújtott speciális szolgáltatások kulcsfontosságú eszközei az együttmüködések ösztönzésének és megfelelő kombinációjuk jó hatással lehet a klaszterben müködő szervezetek teljesítményére és ezáltal a klaszter egészének sikerességére (NERGER, M. et al. 2014., Christensen, T. et al. 2012, KeTELS, C. et al. 2013). Legföbb tevékenységeik a kölcsönös bizalom és közös klasztertudat felépítésére, a kutatás-fejlesztési és innovációs tevékenységek ösztönzésére és különbözö üzletfejlesztési feladatokra, közös piaci megjelenésekre és a nemzetközi kapcsolatok ápolására irányulnak. A Dél-alföldi Régióban létrehozott klaszterek az elnyert pályázati források nagy részét a klaszteres előnyök pontos egyértelmü definiálására és stratégiába foglalására, továbbá az ezen előnyök fokozására irányuló menedzsment tevékenységek és szolgáltatások fejlesztésére fordították és a közel 10 éves müködésük során számos tapasztalat gyült össze ezen a területen, így a kutatásom során az alábbi hipotézist állítottam fel:

A Dél-alföldi Régió klaszterei kihasználják a klaszteres együttmüködésekböl származó elönyöket, jelentős hozzáadott értéket képviselnek a klasztertagjaik számára, mely elönyök erösítésében a klasztermenedzsment szervezeteknek nagy szerepe van.

\section{Hipotézis}

A klaszterek sikerességében fontos szerepe van az innovációnak A klaszteres együttmüködések jelentős szerepet játszanak a vállalatok közötti és a térségekben lezajló innovációs folyamatokban, a regionális gazdaságfejlesztés és az innováció ösztönzésének egyik meghatározó eszközeként (PorTER, M.E. 1998, IsAKSEN, A. - HAUGE, E. 2002, ENRight M. J. 2003, Delgado, M. et al. 2014). A klaszter összekapcsolja az innováció szempontjából legfontosabb szereplöket a gazdasági, a tudományos és a kormányzati szféra képviselőit (ETZKOWITZ, H. - LEYDESDORFF, L. 2000). Közös fórumot és lehetőséget biztosít a személyes találkozásokra, felgyorsítja az információáramlást, a tudás, különösen a rejtett tudás átadását, rugalmasabb és gyorsabb problémamegoldást, alacsonyabb költségeket és kevesebb bizonytalanságot eredményez. A kooperáció és a közösen megvalósított fejlesztések, projektek hozzájárulnak a különbözö szereplök közötti interakciók hiányából adódó innovációs szakadékok áthidalásához, valamint az egyetemi szférában megtermelt tudás piaci környezetben történő alkalmazásához (KETELS, C. et al. 2013). Az innovációt támogató környezet vonzóvá válik a külső befektetők, pénzügyi intézmények számára is, így a klaszterek révén a magas kockázatú költséges kutatás-fejlesztési tevékenységekhez szükséges pénzügyi források, pályázati pénzek, kockázati tőke elérhetősége is javul. A támogató és tudás-intenzív környezetben könnyebben alakulnak ki és fejlődnek az új, innovatív start-up és spin-off vállalkozások (COOKE, P. 2001). A klaszterek tehát kedvező környezet teremtenek az innovációnak, hiszen rendelkezésre áll a megfelelő tudásbázis és a tudásáramlást és tapasztalatcserét támogató egyéb tényezők, ezáltal a klaszterek az innováció, a növekedés és versenyképesség hatékony eszközeivé válhatnak. Regionális viszonylatban a Közép-Magyarországi régió kiemelkedő teljesítménye után a Dél-alföldi Régió előkelő helyen szerepel a régiók listáján a rendelkezésre álló kutatás-fejlesztési hátteret, $\mathrm{K}+\mathrm{F}$ erőforrások, $\mathrm{K}+\mathrm{F}$ ráfordítások és a létrejött szabadalmak tekintve. A régióban a kutatási tevékenységek nagyfokú területi koncentrációja tapasztalható, melyben nagy szerepe van a szegedi tudásközpontnak és a Szegedi Tudományegyetemnek (KSH 2013, 2017). A régióban létrejött klaszterek közel fele Csongrád megyéhez és ezen belül is Szegedhez köthető. A Szegedi Tudományegyetem pedig a létrejött klaszterek több, mint $40 \%$-ában részt vesz teljes jogú vagy pártoló tagként. Ezen kívül a régió további tudományos és kutatási központjai is bevonásra kerültek a klaszterek müködésébe. A régióban müködő klaszterek iparági, szakterületi megoszlását tekintve jól illeszkednek a Nemzeti Intelligens Szakosodási Stratégiában meghatározott megyei és országos prioritásokhoz, szakterületekhez (Nemzeti Intelligens Szakosodási Stratégia 2014). A magas innovációs és exportpotenciállal rendelkező 
Akkreditált klaszterek létrejöttében is kiemelkedő a régió helyzete, mivel a létrejött 36 Akkreditált klaszter 1/4-e a Dél-alföldi Régióhoz köthető. Ezen klaszterek és tagjaik 2007 és 2013 között jelentős összegü forrásokat hívtak le a kutatás-fejlesztési tevékenységeikre és nagy számban valósítottak meg innovációs projekteket (Pénzügyminisztérium, GFP HÁT, Nemzetközi és Klaszter Osztály 2014). Ezek alapján a kutatásom harmadik hipotézisként azt a felvetést vizsgáltam meg, amely szerint:

A Dél-alföldi Régió klaszterei a regionális tudáscentrumok köré összpontosulnak és magukban foglalják a kutatás-fejlesztési tevékenységek legfontosabb szereplöit, ezért kiemelkedö kutatás-fejlesztési és innovációs tevékenységet folytatnak.

\section{Hipotézis}

Egy klaszter tevékenysége és müködése csak akkor tekinthető igazán sikeresnek, ha mind szakmai, mind pénzügyi szempontból is hosszútávon fenntartható. A jól müködö, versenyképes klaszterek esetében is fontos, hogy nyomon kövessék a legújabb iparági, szakmai és klaszteres irányokat, trendeket és ezekhez illeszkedve rendszeresen meg tudják újítani a stratégiájukat, céljaikat és tevékenységüket. A klaszterek esetében fontos kérdés továbbá az együttműködés anyagi hátterének, finanszírozási forrásainak megteremtése, hiszen a közös szakmai munka kereteinek biztosítása, a klaszterszervezetek működése, a közös tevékenységek, megjelenések jelentős költségekkel járnak. Ezeket a költségeket a klaszterek részben belső a tagoktól kapott forrásokból és külső egyéb szervezetek által nyújtott támogatásokból fedezik. A klaszterek finanszírozási szerkezetében még nagy jelentősége van a külső támogatási forrásoknak, de az idő előrehaladtával, a hosszabb müködési múlttal rendelkező klaszterek esetében már megfigyelhető egyfajta pozitív változás és a bevételek között egyre nagyobb arányt képviselnek a klaszertagoktól és a különböző szolgáltatásból származó üzleti bevételek (KETELS, C. et al. 2013). A nemzetközi klaszteres trendek is a klaszterszervezetek külső pénzügyi támogatásoktól való függetlenedésének fontosságát és ezzel párhuzamosan a nem pénzügyi jellegü ösztönzők jelentőségét hangsúlyozzák (MEIER ZU KÖCKER, G. - MÜLLER, L. 2015). 2014- től kezdődően a hazai klaszterprogramok célzott pályázatokkal erősítették a klasztermenedzsment szervezetek piacképes szolgáltatásainak kialakítását (GINOP 2014). Mivel a régió klaszterei kiemelkedően teljesítettek a különböző klasztertevékenységeket támogató pályázatokon, melyeknek sokszor alapfeltétele volt a stratégiák és célok rendszeres aktualizálása és célzott támogatásokat kaptak a szolgáltatási portfóliójuk üzleti alapokra helyezésére, így a kutatásom során utolsóként a következő hipotézis teljesülését vizsgálom:

A Dél-alföldi Régióban létrejött klaszterek egy részének sikerült stabil pénzügyi és szakmai növekedési pályára lépniük, így a jövöben önfenntartóvá válhat a tevékenységük. 


\subsection{A kutatás során alkalmazott módszerek}

A doktori kutatásom során többféle módszert alkalmaztam annak érdekében, hogy átfogó képet kapjak a Dél-alföldi Régió klaszteresedési folyamatairól, a létrejött klaszterek sajátosságairól és a kutatási tervemben kijelölt sikertényezők vizsgálatáról.

A kutatásom legfontosabb részét a Dél-alföldi Régió klasztereinek körében végzett interjús elemzés adta. Félig strukturált interjúkat készítettem az előzetesen kiválasztott klaszterek vezetőivel és menedzsereivel, annak érdekében, hogy mélyebb és részletesebb információhoz jussak a klaszterek sikerességével kapcsolatos tényezőkre vonatkozóan, továbbá, hogy megismerjem a klasztervezetők ezekkel kapcsolatos tapasztalatait és egyéni nézőpontjait. Az interjúkat 2015 január és 2016 júliusa között 20 klaszter vezetőjével és/vagy menedzserével folytattam le.

Az elemzésbe bevont klaszterek kiválasztása során arra törekedtem, hogy olyan klaszterek vezetöit, menedzsereit vonjam be a kutatásba, amelyek:

- A régió fejlődése és versenyképessége szempontjából fontos iparágakban vagy szakterületeken müködnek. Ezeket az iparágakat, szakterületeket a Regionális Operatív Program, a Megyei Területfejlesztési Koncepciók és a Nemzeti Intelligens Szakosodási Stratégia elemzése alapján tudtam kijelölni.

- Fokozott klaszteres aktivitást mutatnak.

A klaszterek aktivitását a honlapjuk segítségével (amennyiben rendelkezésre állt), illetve a különböző célzott klaszteres rendezvényeken való részvételi aktivitással tudtam felmérni. (Megvizsgáltam a klaszterek honlapját, hogy milyen gyakran aktualizálják, tesznek közzé eseményeket, híreket, továbbá részt vettem a 2012-2015 között megrendezett legfontosabb regionális, vagy helyi klasztereknek szóló rendezvényeken és konferenciákon). Nagyjából 5 olyan eset volt, amikor a klaszter a honlap alapján még mutatott bizonyos aktivitást, az előzetes interjúegyeztetés során azonban kiderült, hogy már kizárólag csak a pályázati fenntartási kötelezettségek miatt nem szüntetik meg a klasztert, így ezeket már nem akartam bevonni az elemzésbe.

- Akkreditált klaszterek és/vagy végeznek valamilyen jellegü kutatás fejlesztési vagy innovációs tevékenységet. $\mathrm{Az}$ akkreditált klaszterek listája elérhető volt a Nemzetgazdasági Minisztérium honlapján keresztül. A további $\mathrm{K}+\mathrm{F}+\mathrm{I}$ tevékenységeket a $\mathrm{K}+\mathrm{F}$ pályázatokon nyertes szervezetek listája alapján tudtam felmérni. Ezen felül az interjúk leegyeztetése egy rövid telefonos/személyes beszélgetéssel indult, melyben külön rákérdeztem (azokban az esetekben, ahol bizonytalan voltam) a klaszter $\mathrm{K}+\mathrm{F}+\mathrm{I}$ aktivitására.

- A fentieken kívül fontosnak tartottam továbbá, hogy a klaszterek legalább 3-5 éves müködési múlttal rendelkezzenek, hiszen ennyi idő alatt már felhalmozódhatott annyi tapasztalat, ami az interjú lefolytatásához szükséges. Ez alól 1 kivételt tettem, a lézerfizika területén létrejött klaszter esetében, azonban ezt a klasztert a szakterület fontossága és a külső ajánlások miatt éreztem fontosnak bevonni a kutatásba.

Kiindulási pontnak a régióban müködő akkreditált klaszterek listáját vettem alapul, majd arra kértem az interjúalanyokat, hogy javasoljanak olyan további klasztermenedzsereket, akiket véleményük szerint még érdemes lehet bevonnom a kutatásba. Ennek eredményeként bekerült néhány olyan klaszter is a kutatásba, amely ugyan nem nyert el támogatási forrásokat, vagy nem rendelkezik akkreditációval, mégis kiemelkedő szerepe van a régióban. Az interjúalanyok körének további bővítését két okból sem láttam már szükségesnek. Egyrészről mivel a 15. interjút követően már elég sok ismétlődő motívum volt felismerhető a válaszokban és újabb nézőpontok nem jelentek meg. Másrészről nagyjából a régióban létrejött 51 klaszterből a bevont 20 volt az, aki az interjú időpontjában is aktív tevékenységet folytatott és megfelelt az általam meghatározott szempontrendszernek. 
Az interjúk nagyjából 60-90 percet vettek igénybe és az alábbi témaköröket érintették:

- A klaszter kialakulása, összetétele, földrajzi beágyazottsága.

- A klaszter belső szerkezete és müködése, klaszter menedzsment tevékenysége, erösségei, gyengeségei.

- A klaszter szolgáltatásai, a klaszterek hozzáadott értéke a tagok számára.

- A klasztereken belül megvalósuló együttmüködések, közös projektek innovációs tevékenységek.

- A klaszter finanszírozása, fenntarthatósága, jövőbeni tervek és stratégiai célok.

Az interjúk megbízhatóságát és eredményeit nagyban növelte, hogy én magam is dolgoztam klasztermenedzsment szervezetben, így talán az átlagosnál jobban ismerem a területet és személyesen is ismertem több klaszter vezetöjét. Ennek köszönhetően a legtöbb esetben gyorsan sikerült kialakítanom az interjúhoz szükséges bizalmi légkört.

Az interjúalanyok közül 16 klasztermenedzseri pozíciót tölt be a klaszterben és 4 esetben klasztervezetőnek nevezték magukat az interjúpartnerek, mely klaszterelnöki, vagy ügyvezető elnöki pozíciót jelentett. (Az elemzés során vegyesen alkalmazom a klasztermenedzser és klasztervezető megnevezéseket, melyek ebben az esetben átfogóan az interjúalanyokat jelölik). Az interjúpartnerek nagy része már több éves klasztervezetési tapasztalattal rendelkezik, mivel a klaszter megalakulása óta betöltik a pozíciójukat. Több klasztermenedzsernek ez a fő hivatása és ezen a területen képzeli el a személyes fejlődését, előmenetelét is.

Az interjúk során érintettem minden előre meghatározott kérdéscsoportot, de igyekeztem teret adni a kötetlen beszélgetésnek és az interjúvázlattól eltérő gondolatmeneteknek is. A személyes tapasztalatom alapján úgy érzem, az interjús felmérésem egyik korlátját az adja, hogy a klasztermenedzserek talán igyekeznek egy kicsit pozitívabb képet mutatni a klaszterről, hiszen annak sikeressége az ő munkájuk fokmérője is. Másrészről az interjúk leginkább csak feltárnak bizonyos jelenségeket a klaszterekkel kapcsolatban, ahhoz, hogy ezeket a jelenségeket még jobban alátámasszuk, vagy a klasztereken belüli arányát meg tudjuk adni, szükséges lenne egy széles körü, kvalitatív elemzés is a klaszterek körében. A kutatásom másik korlátját az adja, hogy az elözetes szándékaim ellenére sem sikerült a klasztertagok véleményét felmérni (alacsony válaszadási hajlandóságuk miatt) és beépíteni az eredményekbe. Az interjúk és az azokból levont következtetések nyilvánvalóan kizárólag a klasztermenedzserek véleményét és hozzáállását tükrözik, mely sok esetben eltérhet, jellemzően pozitívabb képet adhat a klaszterben résztvevő tagok véleményétől. Így viszont van néhány olyan terület, amelynél a klasztertagok elégedettségét, hozzáállását és attitüdjeit kizárólag a klasztermenedzserek szemszögéből tudtam bemutatni.

Az interjúkat jellemzően a klaszterek székhelyén, telephelyén irodájában készítettem el, így még inkább módomban állt megismerni a menedzsment munkakörülményeit, a további kollégákat, sőt volt olyan eset is, amikor a klaszter közös termékeit is megmutatták az interjúalanyok. Egy alkalommal volt, amikor a klasztermenedzser kérésére skype segítségével történt meg az interjú elkészítése. Az interjúkról hangfelvételt készítettem az interjúalanyok hozzájárulásával, így sokkal jobban tudtam figyelni arra, hogy a beszélgetés során jobban megnyíljanak az interjúalanyok.

Az interjúk kiértékelésénél sorszámokat használtam, mely sorszámok az anonimitás érdekében nem egyeznek meg a felmérésbe bevont klasztereket bemutató táblázat sorrendjével.

Az elemzés néhány kérdésénél összehasonlítási céllal alapul vettem a 2010-ben a régióban működő 17 klaszter vezetőjével készített interjús elemzés eredményeit is. A 2010-es elemzést a „Dél-alföldi Régióért” Nonprofit Kft. keretében a Magyarország-Szerbia Határon Átnyúló 
Együttmüködési Program PACCLE c. projektjének keretében folytattuk le, a régióban 2010ben működő klaszterek vezetőivel. Az összehasonlítás segítségével néhány konkrét területen azt vizsgáltam, hogy a mennyiben tudtak 5 év alatt változni vagy fejlödni a klaszteres tevékenységek és célok.

A klasztertagok gazdasági, foglalkoztatási, vagy kutatás-fejlesztési teljesítményére vonatkozóan nem állnak rendelkezésre $\mathrm{KSH}$ adatok, mivel a vállalkozásoknak a kötelező adatszolgáltatások során nem szükséges jelölniük, hogy klasztertagok vagy sem. Ilyen jellegü statisztikai adatokat csak önkéntes vagy pályázatokkal kapcsolatos kötelező adatszolgáltatás keretében lehet bekérni a klaszterekben résztvevő vállalkozásoktól, így azok csak nagyon korlátozott számban, kizárólag az akkreditált klaszterekre vonatkozóan állnak rendelkezésre. $\mathrm{Az}$ elemzésem elkészítéséhez a Pénzügyminisztérium, Gazdaságfejlesztési Programok Végrehajtásáért felelős Helyettes Államtitkárság - PM GFP HÁT) belül müködő Nemzetközi és Klaszter Osztály bocsátott rendelkezésemre néhány adatsort az országosan müködő akkreditált klaszterek teljesítményéről 2013-ra és 2018-ra vonatkozóan. Ennek segítségével néhány releváns mutató erejéig leíró statisztikai módszerekkel röviden kitértem a Délalföldi Régió akkreditált klasztereinek gazdasági és kutatási teljesítményében bekövetkezett változásokra is.

A dolgozatomban esettanulmány módszerrel egy konkrét dél-alföldi klaszter példáját részletesen is elemeztem. Az esettanulmány célja az volt, hogy a kutatásomban felállított hipotézisemet és az interjús elemzés során kirajzolódó eredményeket, jelenségeket egy konkrét előre kiválasztott klaszter segítségével részletesebben elemezzem.

Az esettanulmány alkalmas, hogy mélyebben és többféle nézőpontból be tudjam mutatni a klaszterek eredményessége mögött rejlő összefüggéseket, motivációkat, és egyfajta ,jó példaként" kerüljön bemutatásra más klaszterek vagy a klaszterekkel foglalkozó személyek, szervezetek számára. Az esettanulmány további értékét abban látom, hogy közel 10 évvel az első pályázati források megjelenése után napjainkban mutatja be egy klaszter fejlődési útvonalát, tevékenységeit, sikerességét, jövőbeni terveit, esetleges nehézségeit.

Az esettanulmányhoz felkért klasztert, az alábbi szempontok alapján választottam ki:

- Legalább 5 éve müködjön, hogy kellő tapasztalat és tudás álljon rendelkezésre a klasztermenedzsment részéröl.

- A régió egyik kiemelt és tudásintenzív (S3 stratégia alapján) tudományterületén, vagy iparágában tevékenykedjen.

- Változatos összetételü klaszter legyen, melyben kkv-k, egyetemek, egyéb szervezetek egyaránt tagok.

- Innovatív, többször akkreditált klaszter legyen.

- Jelenleg is aktívan müködjön.

Az esettanulmányhoz 3 félig strukturált interjút készítettem és a klaszteres fejlesztési tervek, stratégiák, prezentációk dokumentumelemzését végeztem el 2018-ban. Az interjúpartnerekként a klaszter menedzserét, a klaszterben résztvevő Szegedi Tudományegyetem kutatás-fejlesztési tevékenységekért és klaszterekért felelős vezetőjét, valamint a klaszterfejlesztési programok és támogatások kidolgozásáért és végrehajtásáért felelős szakértőt kértem fel. A célom az volt, hogy az interjúpartnerek különböző szempontok szerint tudják megközelíteni a kérdéseket, ezáltal változatosabb eredményeket kapjak. Az interjúkra való felkészülésként és az esettanulmány kiegészítéseként a klaszter legfontosabb fejlesztési dokumentumainak, alapító okiratának, szervezeti és működési szabályzatának és cselekvési tervének tartalomelemzését végeztem el, kiemelt figyelmet fordítva a kutatásomban megfogalmazott kérdések megválaszolásához kapcsolódó területekre. 


\section{A KLASZTEREK ELMÉLETI HÁTTERE}

A következő fejezetben áttekintést kívánok adni a klaszterek elméleti hátteréröl, a különböző tudományos irányzatok által kidolgozott megközelítésekről, a legfontosabb fejlődési fázisaikról, valamint a földrajzi és a kapcsolati közelség szerepéről ezekben az együttmüködésekben. Röviden kitérek továbbá a kutatásom szempontjából releváns kérdésekre, úgy mint a klaszter együttmüködések legfontosabb szereplöinek bemutatására, a klaszterek innovációs folyamatokban betöltött szerepére és azokra a kulcstényezőkre, amelyek meghatározhatják egy klaszter sikeres fejlődését, hosszú távú fenntarthatóságát.

\subsection{A klaszterek fogalma, csoportosítása és hozzáadott értéke}

A térbeli koncentrálódással foglalkozó tudományos irányzatok három nagyobb csoportra oszthatóak. A neoklasszikus közgazdaságtani irányzat képviselői Paul Krugman, Masahisa Fujita, Anthony Venable a gazdasági tevékenységek térbeliségét vizsgálják és véleményük szerint a centripetális erőknek köszönhetően törvényszerü a mobil gazdasági tevékenységek térbeli koncentrálódása, klaszteresedése (Krugman, P. 2000, FuJiTA, M. et al. 2000). A második csoport a gazdálkodástudományi irányzat Michael Porterrel, Michael Enrighttal és Arnoud Lagendijkkel az élén, a vállalati együttmüködések térbeliségét helyezi középpontba és az üzleti érdekek mentén magyarázza a térbeli folyamatokat (ENRIGHT, M. J. 1996, 2003, PorTER, M.E. 1998, 2000, LAGENDIJK, A. 1999). A fenti két irányzat elveit szintetizálni igyekvő regionális tudomány a regionális fejlesztést és a térbeli fejlődést helyezi a vizsgálatok fókuszába. Az irányzat legjelentősebb képviselői többek között Allen Scott, Michael Storper, Peter Dicken és Philip McCann (ScOTT, A. J. 1988, STORPER, M. 1997, DickEN, P. 2011, MCCANN, P. 2008).

Az Európai Unió négy iskolát különböztetett meg a klaszterek kialakulásával kapcsolatban: az olasz, a kaliforniai, az északi vagy skandináv iskolát és a porteri klasztermegközelítést (EUROPEAN COMMISSION 2002). Az olasz iskola esetében a fogalom alapját a Marshallig visszanyúló iparági körzetek adják. Az iparági körzetek, mint jelenségek Olaszországban honosak, hiszen itt alakult ki az a speciális szervezeti modell, amely a társadalmi-gazdasági fejlödés és a növekedés alapja. Alfred Marshall (1930) a Principles of Economics-ban az iparági körzetek legfontosabb jellemzőit és fejlödését mutatta be és nem csak a helyi gazdasági környezetbe ágyazódott üzleti kapcsolatok fontosságát hangsúlyozta, hanem a jelenség egyéb társadalmi-kulturális aspektusait is. Az iparági körzetek kialakulását három tényezőre vezette vissza, úgy mint a helyi pozitív extern hatások, az input-output kapcsolatok és a technológiai hatás, valamint a tudás túlcsordulás (MARSHALL, A. 1920). A modell 1979ben az olasz régiók sikerének eredményeként került újraértelmezésre Becattini által, aki elsőként határozta meg az ipari körzet fogalmát, mint a gazdasági teljesítményhez kapcsolódó társadalmi- területi entitást, előtérbe helyezve annak társadalmi, történelmi és kulturális jellemzöit (BECATTINI, G. 1989). Az ipari körzeteket a rugalmas specializáció és a kis- és közepes méretű vállalkozásokat magába foglaló vertikálisan integrált termelési folyamatok jellemzik (BRUSCO, S. 1992, DUSEK, T. 1999).

A kaliforniai iskola az új ipari területek növekedését elemezve a termelési értéklenc mentén kialakult vállalati együttmüködésekre helyezte a hangsúlyt, ahol az együttmüködések révén jelentős költségcsökkentés érhető el és specializált helyi munkaerő piacok alakulnak ki (SCOTT, A. J. 1988). Az északi vagy skandináv iskola szerint az innováció adja a vállalatok versenyképességének alapját, így klaszteres együttmüködések egyik fő célja a tudásgenerálás és tudásátadás, a tapasztalatok és a nem kodifikálható, tacit tudás megosztása (LuNDVALL, B. A - JOHnson, B. 1994, COOKE, P. 2001). A porteri klasztermegközelités esetében a fö hangsúly az előző három iskolával szemben kevésbé a helyspecifikus elemeken van, hanem a 
vállalati szintü versenyelőnyökön és azok forrásain. A klaszter alapját a vállalatok és intézmények közötti együttműködés és információáramlás adja (PORTER, M.E. 1990, PORTER, M.E. 1998).

A klaszterekre vonatkozó szakirodalom igen széleskörü és változatos, mind a fogalom magyarázata, mind annak eredete tekintetében. A gazdasági tevékenységek térbeli koncentrálódására is különböző kifejezések terjedtek el, például Olaszországban az iparági körzet, Franciaországban a lokális termelési rendszer, az angolszász országok és a nemzetközi gyakorlat pedig a „cluster” kifejezést használják (LENGYEL, I. - DEÁK, SZ. 2002). A klasztereknek nincs egy egységes és pontos definíciója, inkább egy olyan gyüjtőfogalomként kezelhető, amely a kulturális háttér és attitüdök, valamint a gazdasági szabályozás eltérései miatt a vállalatok és intézmények együttmüködéseinek változatos formáit foglalja magában (LENGYEL, I. 2010).

A klaszterkoncepció és a klaszter fogalom megalkotását sokan Michael E. Porter (1990) nevéhez kötik, aki szerint a klaszterek kialakulását olyan folyamatnak tekinthetjük, amely során egy szükebb földrajzi környezetben egymás közelébe települt, egyes tevékenységi területeken együttmüködő, más területeken azonban egymással versenyző cégek olyan együttmüködési hálózatot alakítanak ki egymás között, amelyekkel együttes versenyképességüket javítani tudják (PORTER, M.E. 1990, PORTER, M.E. 2000). Rosenfeld (1995) értelmezésében a klasztert olyan földrajzilag körülhatárolható koncentráció, amelyet olyan vállalatok alkotnak, akik hasonló, kapcsolódó vagy egymást kiegészítő tevékenységet végeznek, egymással aktív kommunikációt folytatnak, gyakran specializált infrastruktúrán, munkaerőpiacon és szolgáltatásokon osztoznak és közös kihívásokkal néznek szembe (RosenFeld, S. A. 1995). Enright (1996, 2003) megfogalmazásában a klasztertag vállalkozásokat és kapcsolódó szervezeteket a vásárlói-beszállítói kapcsolatok, közös infrastruktúra, közös technológiák, közös munkaeröpiac köti össze és a közös klaszterhez tartozás révén növelik a versenyképességüket, specializációjukat és az identitásukat (ENRIGHT, M. J. 1996, ENRIGHT, M. J. 2003).

Az Európai Bizottság (2003) a Porteri definícióra alapozva egy átfogó megfogalmazást alkalmaz a klaszterekre, mely szerint a klaszter olyan vállalatok és kapcsolódó intézmények csoportja, amelyek (EUROPEAN COMMISSION 2003):

- együttmüködnek és versenyeznek,

- egy vagy néhány régióban földrajzilag koncentráltan helyezkednek el,

- bizonyos közös technológiával és szakismerettel összekötött területre specializálódnak,

- tudományos alapúak, vagy hagyományosak,

- intézményesítettek, vagy nem intézményesítettek,

- pozitív hatásuk van az innovációra, a versenyképességre, a szaktudásra és információáramlásra, valamint a növekedésre.

A földrajzi közelséget tekintve a klaszterek vagy ipari körzetek úgy jellemezhetőek, hogy a helyi üzleti hálózatokba ágyazódva, a gazdasági és nem gazdasági kapcsolatok integrált és összehangolt halmaza, az üzleti vállalkozások körében és azon kívül (KEEBLE, D. WILKINSON, F. 1999, p. 299., GIULIANI, E. 2010).

A hazai kutatók közül Grosz (2004) egy elég széles körü meghatározást alkalmazott, mely szerint ,„a klaszterek az egy iparágban, egy értéklánc-rendszer mentén szervezödö, egymással egyszerre versengö és szoros együttmüködési kapcsolatokat ápoló független gazdasági szereplök és nonprofit intézmények, szervezetek olyan területileg koncentrált együttmüködési hálózata, amely jelentösen hozzájárul mind az abban résztvevök, mind az egész régió, vagy térség versenyképességének növekedéséhez" (GROSZ, A. , 2004, 274. o.). 
Patik és Deák (2005) tanulmányukban a klasztert olyan helyi/regionális húzóágazatnak tekintik, amelyekben a vállalatok munkamegosztás mellett, közös infrastruktúrát, technológiát, munkaerőbázist és tudásbázist vesznek igénybe (PATIK, R. - DEAK, Sz. 2005).

Lippert (2015) kutatásában egy hazai klasztereket vezetői szempontból leíró definíciót alkotott mely szerint a klaszter: „Különbözö vállalkozások és nonprofit szervezetek olyan jogi személyiség nélküli, de formálisan is létrejött együttmüködési formája, ahol az alapító és csatlakozó tagok, szuverenitásukat teljes mértékben megtartva az üzlet, az innováció, az információ és a támogatások szempontjai köré csoportosuló egyéni céljaikat, az összefogásban rejlö lehetöségek kihasználásával próbálják elérni. Együttmüködésüket egy tudatosan kialakitott és közösen elfogadott rendszer szerint egy választott vezetön vagy szervezeten keresztül irányitják" (LIPPERT, R. 2015, 162. o.).

Az elmúlt 15 évben a klasztereknek számos különböző szempont szerinti csoportosítása született meg. A klaszterek két alaptípusának a területi koncentráció figyelembevételével az iparági és a regionális klasztert tekintjük. Az iparági klaszter az egymással kooperáló vállalatok és a kapcsolódó intézmények, specializált szolgáltatók olyan hálózata, amely egy teljes termelési értékláncot képes lefedni, a munkamegosztás magas foka jellemzi. Többé, kevésbé koncentráltak, de a területiség itt kevésbé hangsúlyos, hiszen a szereplők gyakran akár egy teljes országot is lefedhetnek (ENRIGHT, M. J. 1996, FESER, E. J.,- BERGMAN, E. M. 1999). A regionális klaszter esetében a földrajzi közelség és a lokalizációs előnyök sokkal inkább előtérbe kerülnek, hiszen ezek a hálózatok valamilyen helyi húzóágazat vagy egy adott régió meghatározó exportképes iparága köré szerveződnek. Ebben az esetben mind a területi, mind a gazdasági koncentráció igen magas fokú (OECD 1999, FESER, E. J.,- BERGMAN, E. M. 1999). A földrajzi behatároltság szerint az iparági klasztereken belül megkülönböztetünk mega-, mezo- és mikorklasztereket, a regionális klasztereknél a térségi bázist tekintve makro-, regionális és lokális klaszterekröl beszélhetünk (LENGYEL, I. 2002).

McCann (2008) a klaszterek három típusát különítette el, a tiszta agglomerációt, az iparági komplexumot és a társadalmi hálózatokat, a klasztertagok közötti kapcsolatok, a klaszter dinamikája és a kapcsolati közelség tekintetében. A klaszterek estében sokszor keverednek ezek a típusok és csak az állapítható meg, hogy mely típus a domináns.

A tiszta agglomeráció jegyeit hordozó klaszterek esetében a versenyelönyök a vállalatok térbeli elhelyezkedéséből adódnak, nincsenek meghatározó vállalatok és a klaszteren belüli kapcsolatrendszer is folyamatosan változik (MCCANN, P. 2008). Ezen típusú klaszterek müködése inkább a nagyvárosi térségekre jellemző. Az iparági komplexumok estében a fentivel ellentétben a klaszterben megtalálhatóak a domináns helyi vállalatok, a klaszteren belüli kapcsolatok hosszú távú, stratégiai együttmüködések, melyek leginkább a tranzakciós költségek minimalizálása érdekében jöttek létre. A klaszter erősen hierarchikus és már kevésbé nyitott, mint a fenti esetben, bekerülni jelentős befektetések révén tudnak újabb vállalkozások. Az ilyen típusú klaszterek inkább a kisebb városokban jönnek létre (MCCANN, P. 2008). A társadalmi hálózatban leginkább a bizalmi kapcsolatok dominálnak, mintsem üzleti érdekek. Az azonos értékrendszer, történelmi és kulturális háttér, közös hagyományok és a személyes kapcsolatok teremtik meg az együttmüködés alapját. Ilyen társadalmi hálózatok a rugalmas specializációra építő olasz iparági körzetek, de az új high-tech klaszterek is hasonló társadalmi hálózatként értelmezhetőek, mivel azokon belül nagyon szoros kapcsolatban állnak a vállalatok és az innovációs tevékenységük is erre a kognitív közelségre épül. A vállalatok közötti együttmüködés mellett a versengés is egyaránt jelen van. Ezen hálózatok lokális vagy regionális szinten müködnek és a lokalizációs agglomerációs előnyöket hasznosítják (MCCANN, P. 2008).

Miller és szerzőtársai (2001) a vállalati együttműködéseken és az üzleti környezeten alapuló 6 klasztertípust határoztak meg, úgy mint a függőleges termelési lánc, a kapcsolódó szektorok aggregációja, regionális klaszterek, iparági körzetek, helyi hálózatok és az innovációs miliő (MiLleR, P. et al. 2001). 
Cruz és Texiera (2009) a klaszteres szakirodalom széleskörü áttekintése és elemzése révén 9 fő csoportot különített el a klaszterek megközelítésére vonatkozóan (CRUZ, S.- TEXIERA, A. 2009):

1. Agglomerációs gazdaságok, területi agglomerációs elméletek.

2. Tudásalapú elméletek: a lokalizált tanulási folyamatok, tudástúlcsordulás, tacit tudás kapcsolata a klaszterekkel.

3. Rendszer elméletek, klaszterek a regionális és nemzeti innovációs folyamatokban.

4. Ipari politikák és regionális fejlesztési politikák.

5. A klaszterek hálózati és társadalmi megközelítései.

6. Nemzetköziesedés, globális hálózatok, multinacionális vállalatok és helyi klaszterek kapcsolata.

7. A klaszterek intézményi megközelítései.

8. Módszerek és intézkedések: statisztikai adatok és módszerek a klaszteresedési folyamatok objektív magyarázatára és vizsgálatára vonatkozóan.

9. Egyéb elméletek, melyek gyakran pénzügyi jellegü és az ökológiai vonatkozásai a klaszteres megközelítéseknek.

A klaszterek életciklusainak is többféle megközelítése létezik, de a klaszterek jellemzően az indulás, a növekedés és fejlődés, az érettség, majd a hanyatlás és átalakulás különböző fázisain mennek keresztül (LENGYEL, I. 2002, MENZEL, M.P. - FORNAHL, D. 2007). Az Európai Bizottság megbízásából készült elemzésben a klaszterek fejlődésének 6 fázisát különböztették meg a szakértök: a megalakulástól és a speciális szervezeti és környezeti háttér megteremtésétől, valamint az új szervezet kialakításától kezdve, a klaszter bővülésén, a tudás és információáramlás erősödésén át egészen a klaszter hanyatlásáig vagy megújulásáig (ISAKSEN, A. - HAUGE, E. 2002).

Andersson és szerzőtársai (2004) az alábbi 5 szintet azonosították a klaszterek életciklusában (ANDERSSON, T. et al. 2004):

- Agglomeráció: Egy régióban számos vállalkozás és más szereplő van.

- Feltörekvő klaszter: A klaszteresedés első lépéseként az agglomeráció bizonyos szereplői elkezdenek egymással kooperálni az alaptevékenységük kapcsán, továbbá felismerik a kapcsolatokban rejlö közös lehetőségeket.

- Növekvő klaszter: Új szereplők jelennek meg ugyanarra vagy a kapcsolódó tevékenységekre. A szereplök között új kapcsolatok alakulnak ki. Formálisan vagy informálisan belép egy klasztermenedzser szervezet. Gyakran közös honlap, márka és megjelenés is kialakításra kerül.

- Érett klaszter: A klaszter méretében eléri a kritikus tömeget. Külső kapcsolatai fejlődnek más klaszterekkel, régiókkal. A belső dinamizmus eredményeként új vállalkozások jönnek létre (start-up, spin-off cégek, leányvállalatok).

- Átalakulás: A piacok, technológiák és egyéb folyamatok változásával a klasztereknek is változniuk kell a túlélés érdekében. Alkalmazkodniuk kell és újításokat bevezetniük, mely történhet a termékek és szolgáltatások fejlesztésével, a meglévő klaszterstruktúra és tevékenység átalakításával, vagy akár egy teljesen új klaszter alapításával.

A klaszterek müködése által elérhető előnyök igen széleskörüek és többféle szempont szerint csoportosíthatóak. A klaszterek régiók versenyképességére gyakorolt hatásai közül elsősorban a termelékenység javulása, az innovációs kapacitások növekedése és az új vállalkozások megjelenése emelhető ki (COOKE, P. 2001, LENGYEL, I. 2010). A klaszteres együttmüködések fontos szerepet játszanak a vállalatok közötti és a térségekben lezajló innovációs folyamatokban, a regionális gazdaságfejlesztés és az innováció ösztönzésének 
egyik fontos eszközeként (PorTER, M.E. 1998, IsAKSEN, A. - HAUGe, E. 2002, ENRiGHT, M. J. 2003, DELGADO, M. et al. 2014).

A földrajzi közelségből adódó előnyök vagy agglomerációs előnyök három típusa (nagyvállalati, lokalizációs és urbanizációs) közül a lokalizációs és urbanizációs előnyök tudják hatékonyan elősegíteni a klaszteresedési folyamatokat. A lokalizációs agglomerációs elönyök vagy MAR (Marshall-Arrow-Romer) extern hatások egy adott iparág vállalkozásainak térbeli közelségéből, koncentrációjából adódnak és jellemzően a specializációra épülnek. Ezen előnyök külsők a vállalatok, de belsők az adott iparág számára és inkább a kisvárosi térségekre jellemzőek. Ehhez képest az urbanizációs agglomerációs elönyök vagy Jacobs-féle extern hatások több iparág egy régióban való elhelyezkedéséböl adódnak és a nagyvárosi térségekben jellemzőek. Az előnyök külsők a vállalatok és az iparág számára is (LENGYEL, I. - RECHNITZER, J. 2004).

A klaszteres együttmüködések mögött a szereplők számára egyértelmüen definiálható üzleti érdekek húzódnak meg mivel minden résztvevő előnyöket realizál a kooperáció révén. A globális versenyben résztvevő vállalatok hajlandóak olyan együttmüködéseket kialakítani, amelyekből többet profitálnak, mint amennyi befektetést vagy kötelezettséget vállalnak ezért cserébe. A klaszterek a térbeli koncentrálódás révén elérhető lokalizációs előnyöknek köszönhetően könnyebben és gyorsabban jutnak bizonyos információkhoz, tapasztalatokhoz, speciális iparági tudáshoz, csökkenthetik a költségeiket és a kockázatukat, gyorsabban tudnak alkalmazkodni a piac változásaihoz és élvezik a helyi társadalom és intézmények támogatását (LENGYEL, I. - DEÁK, Sz. 2002). A földrajzi közelségből származó előnyök persze a klaszterektöl függetlenül is felmerülhetnek, azonban a klasztereken belül kialakul egyfajta tudatosság is a földrajzi közelség pozitív externális hatásainak kiaknázásra. Rendszeres együttműködéseket alakítanak ki erre irányulóan, melyek elősegítik a tudásgenerálási és átadási folyamatokat, kiemelt tekintettel a kódolatlan tudás átadására. (SZANYI, M. et al. 2009). A klaszterek regionális jellege az erőteljes földrajzi koncentrációból ered, azonban az információáramlás felgyorsulásával, az új technológiákkal csökken az információátadás költsége és ez kedvez a különböző interregionális és transznacionális klaszterkezdeményezéseknek is. Persze ezzel egyidejüleg továbbra is vannak olyan eröforrások és olyan előnyök, amelyek a helyhez kötöttek és erősítik a területi koncentráció jelentőségét (GROSZ, A. 2005).

A klaszterek által nyújtott előnyöket Lagendijk (1999) az alábbi három csoportra különítette el (LAGENDIJK, A. 1999):

- Az első, miszerint megerősödik a vállalatok versenyképessége a lokális szinergiahatásoknak köszönhetően.

- Másrészt a munkamegosztás és specializáció révén javul a résztvevők termelékenysége.

- A harmadik csoportba a helyi kapcsolatokhoz kötődő elönyök tartoznak, miszerint ezekben a vállalatokban egyre inkább megerösödik a helyi identitástudat és nem csak érintetté, de partnerekké is válnak a lokális gazdasági vagy társadalmi problémák megoldásában.

Porter (1998) szerint a versenyelőnyöknek kétféle csoportja létezik a költségelőnyök és a stratégiai pozicionálásból származó elönyök. Költségmegtakarítás adódhat a közösen igénybevett erőforrások, a közösen üzemeltetett infrastruktúra vagy a közös beszerzések révén Másrészről további előnyök származhatnak a szereplők közötti információ- és tudásmegosztásból a közös fejlesztések, projektek eredményeként. Ehhez a szereplöknek tisztában kell lenniük saját és klasztertársaik erősségeivel és olyan kiegészítő kompetenciák kialakítására kell törekedniük, melynek segítségével specializált tevékenységeket tudnak 
végezni és ezáltal újabb piacokat elérni. Az együttmüködések eredményeként minden résztvevőnek világosan kimutatható üzleti elönyöket és közös célokat kell elérnie (PORTER, M.E. 1998).

Lippert (2015) elemzése szerint a klasztertagok közvetlen motivációja alapvetően négy fő témakör köré összpontosul (LIPPERT, R. 2015):

> Az első a termelékenységgel, hatékonysággal, gazdaságosabb müködéssel kapcsolatos célok.

$>$ A második a könnyebb és hatékonyabb tudáshoz, ismerethez, információhoz jutás a klaszteren belül.

$>$ A harmadik terület az innovációs és $\mathrm{K}+\mathrm{F}$ lehetőségek hatékonyabb kiaknázási lehetősége.

$>$ A negyedik pedig a támogatási forrásokhoz való könnyebb hozzájutás lehetősége.

A fenti áttekintés alapján látható, hogy a klaszterek elméleti háttere igen összetett és változatos, számos megközelítést és csoportosítási elvet foglal magában és a klaszterek kialakulása mögött húzódó gazdasági és társadalmi érdekek, motivációk is többféle szempontból közelíthetőek meg. Ez alapján nehéz pontosan meghatározni a klaszterek fogalmának lényegét. Összefoglalóan és a legelterjedtebb definíciók alapján olyan meghatározott iparágak, vagy szakterületek köré szerveződő együttmüködési hálózatok, amelyek meghatározó szereplői a vállalkozások, de kapcsolódnak hozzá különböző oktatási, kutatási szereplők, nonprofit szervezetek, egyéb kiszolgáló intézmények, és amelyek hozzájárulnak a tagjaik versenyképességének növeléséhez és tágabb értelemben az érintett térség gazdasági fejlődéséhez. Az együttmüködésből származó elönyök igen széleskörüek lehetnek a konkrét pénzben mérhető gazdasági előnyöktől kezdve egészen a speciális információkhoz vagy tudáshoz való hozzáférésig, vagy a stratégiai értelemben fontos partnerekkel való kapcsolatokig. A motivációk akár szereplőnként is változhatnak, a legfőbb szempont azonban az, hogy az együttmüködésből származó előnyök, hosszú távon meghaladják a klasztertagok számára az együttműködés kapcsán felmerült ráfordításaik értékét.

\subsection{A földrajzi koncentráció, kapcsolati közelség és a bizalom szerepe a klaszterekben}

A klaszteresedés földrajzi dimenziója a vállalkozások területi koncentrációjából adódik. A globális gazdaság és a globális folyamatok erősödésével azonban megkérdőjeleződhet a klaszterek földrajzi vonatkozásának jelentősége. A globalizáció föbb gazdasági folyamataink eredményeként megjelenő új gazdasági térben a globális vállalatok intenzív tevékenysége és a termelési tevékenységek térbeli dekoncentrációja figyelhető meg. A térbeli dekoncentrációval párhuzamosan azonban bizonyos tevékenységek (döntéshozatal, magas hozzáadott értékü, nagy termelékenységü, stratégiai területek) erőteljes területi koncentrálódása révén a tartós vállalati versenyelönyök lokális forrásai egyre inkább előtérbe kerültek. A globális gazdaságban a vállalatok versenyképességének alapját a helyi üzleti környezetük biztosítja (LENGYel, I. - DEÁK, Sz. 2002). Porter (1998) ezt a jelenséget a globális-lokális paradoxon elméletével magyarázta, mely szerint a globális folyamatok erősödésével a vállalatok globális stratégiákat dolgoznak ki, azonban az adott iparág vezető cégei nagyon koncentráltan helyezkednek el, azokon a területeken, ahol a lokális környezet a legkedvezőbb feltételeket nyújtja a számukra. A klaszteres együttmüködések révén a vállalkozások jobban tudnak alkalmazkodni a globális verseny kihívásaihoz és sikeresebbek tudnak lenni, így 
kiemelt szerepük van a regionális fejlesztési stratégiákban (PORTER, M.E., 1998). A globális folyamatok erősödésével a földrajzi közelség jelentősége is átalakult. A közelség szerepe felértékelödött a személyes kapcsolatok révén elérhetö tudás-és információátadás és a közös értékekre, informális kapcsolatokra épülö együttmüködések, például klaszterek esetében is. (NAGY, E. 2009, PÁL, V.- Boros L. 2010). Mára a gazdaságföldrajzban és a klaszterekkel kapcsolatos kutatásokban is egyre nagyobb figyelmet szentelnek a kapcsolatok jelentőségének és a térbeli közelség mellett a szervezetek közötti kapcsolatok és a tudásáramlás elemzésére helyeződött a hangsúly (BoGGS, J. S. - RANTISI, N. M. 2003, Boschma, R. 2005, Giuliani, E. 2007, Giuliani, E. 2010, Ter Wal, A. L. J.-Boschma, R. 2009). A gazdaságföldrajzban először Manuel Castells (1996) vizsgálta a vállalkozások versenyképessége szempontjából a térbeli elhelyezkedés mellett a kapcsolatok jelentőségét. Az információs és kommunikációs technológia gyors fejlődése és a hálózati gazdaság, mint új társadalmi forma, az információs társadalom kialakulásához vezetett, mely társadalomban a valós tér helyett egyre nagyobb jelentősége van a hálózatokhoz köthető „áramlások terének” (CASTELLS, M. 1996). Az infokommunikációs technológiák fejlődése egy új fogalom a kibertér fogalmát is magával hozta. A kibertérnek vagy más néven virtuális térnek nagy hatása van a társadalmi viszonyok és kapcsolatok alakulására (MÉSZÁROS, R. 2008). Az információs technológiák használata és a globalizáció eredményeként a fizikai tér szerepe egyre inkább visszaszorul és a helyébe lépő hálózatok adnak új keretet a társadalmi folyamatoknak (PINTÉR, R. 2007).

Napjainkban már számtalan példa áll rendelkezésre, arra vonatkozóan, hogy egymástól távoli szereplök sikeresen müködnek együtt, mivel a hálózati együttmüködések révén a távolságok több esetben leküzdhetőek. Az infokommunikációs technológiák fejlödésével, a virtuális térben a távolság fogalma is átértékelödik és a kapcsolati tér vonatkozásában inkább azon múlik a távolság, hogy valakivel kapcsolatba tudunk-e kerülni vagy sem (MÉSZÁros, R., 2010). A közelség (proximity) fogalmának tehát egyre meghatározóbb szerepe van a tudás és különösen a rejtett (tacit) tudás átadásában, a bizalmi kapcsolatok, a közös szakmai nyelvezet, valamint a kollektív tanulási folyamatok kialakításában. A kapcsolati közelség a szervezetek azon képessége, hogy mennyire tudják a tagjaik közötti interakciókat elösegíteni. (BosCHMA, R. 2005, TorRe, A. - RALlet, A. 2005, LengYel, I. 2010). A földrajzi közelségen túl, a kapcsolati közelségnek is fokozott szerepe van a klaszteres együttmüködésekben. A kapcsolati közelségnek több olyan dimenziója van, amely hozzájárul az innovációs miliő kialakulásához. A hatékony együttmüködéshez egyre inkább szükség van olyan nem számszerüsíthető tényezőkre, mint a kölcsönös bizalom, a speciális tudásbázis, a kapcsolati tőke és a társadalmi-kulturális háttér. Az interaktív, kollektív tanulás folyamatában a tapasztalatok és a tudás megosztásában a kapcsolati térnek jelentős szerepe van, hiszen hozzájárul a tudás terjedéséhez, valamint az innováció és az innovatív kapcsolatrendszerek kialakulásához (VAS, ZS. B. 2009, GROSZ, A. - RECHNITZER, J. 2005).

Boschma (2005) a kapcsolati közelség négy típusát különbözteti meg, köztük a kognitív, szervezeti, intézményi és társadalmi közelséget.

- A kognitív közelség esetében a szereplők hasonló tudásbázissal rendelkeznek, a hasonló ismeretek segítségével a tudás, a tapasztalatok és szakmai információk megosztása sokkal hatékonyabb az együttmüködés során. A kognitív közelség egyik speciális formája a technológia közelség esetén, a speciális technológia teremti meg az együttmüködés és kölcsönös tanulás lehetöségét. A túl erős kognitív közelség azonban káros is lehet, hiszen a túlságosan hasonló tudás már negatív hatással lehet a közös együttmüködésre, innovációra, hiszen a szereplök nem tudnak mit tanulni egymástól.

- Intézményi közelséget a közös törvényi vagy jogszabályi háttér, továbbá a közös nyelv, kultúra és szokások teremtik meg. A hasonló üzleti környezet révén a szereplök könnyebben tudnak együttmüködni és az intézményi közelség hozzájárul az interaktív 
tanuláshoz. A túl erős intézményi közelség azonban egyfajta negatív bezáródási folyamatot is eredményezhet.

- A szervezeti közelség a kapcsolatok szorosságát jelenti a szervezeten belül, vagy a szervezetek között. Az erősebb szervezeti közelség serkenti az innovációt, hiszen csökkenti a bizonytalanságot. A szervezeti közelség túlzottan magas mértéke kedvezőtlenül hat a rugalmasságra.

- A társadalmi közelség a bizalomra épülő személyes kapcsolatokat, ismeretségeket jelenti. A társadalmi közelség erőteljesen támogatja a tudás és különösen a rejtett tudás átadását, azonban ebben az esetben is a túlzott bizalom negatív hatással is lehet az együttmüködésre (BosCHMA, R. 2005).

A kapcsolati közelség kapcsán Torre (2008) azonban kiemeli, hogy a szereplök közötti nagy földrajzi távolságok esetén a kapcsolati közelség csak abban az esetben tud igazán hatékony lenni, ha már néhány korábbi személyes találkozás erősíti azt (TORRE, A. 2008). Ezeknek a személyes találkozásoknak föként a kapcsolatok kialakulásának kezdetén van nagyobb jelentősége. A nagyon erős kapcsolati közelség és a helyi kapcsolatokra és a hallgatólagos ismeretekre való túlzott mértékü támaszkodás azonban negatív hatással is lehet az együttmüködésre, hiszen a szereplök elhanyagolják a külső kapcsolataikat és túlságosan a bevált gyakorlatokra és belső információkra építenek, mely egyfajta bezáródási (lock-in) hatást eredményezhet (MARTIN, R. - SUNLEY, P. 2001, BosCHMA, R. 2005).

A földrajzi közelség és a kognitív közelség tehát kölcsönösen támogatják egymást, hiszen a földrajzi közelség segít a kognitív szempontból távoli szereplök például kutatók közötti kapcsolatok kialakulását. Másrészről némi kognitív távolság szükséges az interaktív tanulás és innováció ösztönzéséhez. A fiatalabb cégeknél és a kevésbé erős technológiai tudással rendelkezők esetében a földrajzi közelség segít a kognitív távolság leküzdésében. A kisebb vállalkozások esetében a földrajzi és kognitív távolság jól kiegészítik egymást, hiszen míg ezek a cégek jól beilleszkednek a technológiailag hasonló cégek regionális klaszterébe, jelentős távolsági kapcsolatokat tartanak fenn más cégekkel. A földrajzi közelség segít továbbá az intézményi távolság leküzdésében, tehát az egyetemi-ipari kapcsolatok is könnyebben alakulnak ki, ha a cégek és az egyetemek földrajzilag közel állnak egymáshoz (Singh, J. 2005, Ponds, R. et al. 2007, BRoEKEL, T., - BoschmA, R. 2016).

Ter Wal és Boschma (2009) a triadikus lezárás jelentőségét is kiemelték a hálózatok kapcsán, tehát, hogy nagyobb valószínüséggel jön létre kapcsolat két olyan szereplö között, akik egy közös harmadik szereplövel is kapcsolatban állnak, vagyis a partnerek, partnereivel való együttmüködésnek nagyobb esélye van (TER WAL, A. L. J.-BOSCHMA, R. 2009). Juhász és Lengyel (2018) azonban megállapították, hogy a triadikus lezárás és a földrajzi közelség növelik ugyan a kötések létrehozásának valószínüségét, de nem befolyásolják a kötés tartósságát (JuHÁsz, S. - LENGYEL, B. 2017). Guliani és szerzőtársai 2018-ban egy alulteljesítő tudáshálózat vizsgálata kapcsán pedig arra a következtetésre jutottak, hogy a helyi társadalmi és intézményi kapcsolatok biztosíthatják egy klaszter túlélését, de nem feltétlenül elégségesek a klaszter fejlődéséhez (GULIANI, E. et al. 2018).

A földrajzi és kapcsolati közelség egyaránt hozzájárul a partnerek közötti együttmüködések elmélyüléséhez és a kölcsönös bizalom kialakulásához. A bizalom pedig a klaszterek létrejöttének és fejlödésének egyik kulcstényezője, hiszen a sikeres szervezeti együttmüködések egyik nagyon fontos kulcstényezője. A kölcsönös bizalom megkönnyíti a kapcsolatok kialakítását, a felek közti kommunikációt és a tranzakciós költségek csökkenését is eredményezheti (LANE, C. 1998, ANDERsson, T. et al. 2004, OleKALNS, M. - SMITH, P. L., 2005). A bizalom olyan pozitív attitüd vagy hozzáállás valakihez, amely sokszor múltbéli tapasztalatokon, közös kapcsolatokon vagy háttéren alapul (GAMBETTA, D. 1988). Az 
együttmüködések esetében annak a szintjét jelenti, hogy a partnerek mennyiben érzik úgy, hogy megbízhatnak a másik szavában, ígéreteiben. A hosszú távú kapcsolatokhoz nyilvánvalóan magasabb bizalmi szint szükséges (SIN, L.Y.M. et al, 2005).

A bizalom gazdasági oldalról történő megközelítésének több irányzata is van. A hiten alapuló megközelítés, a kockázati oldalról történő megközelítés és az ehhez kapcsolódó bizalom hiányából eredő megközelítés. A hiten alapuló megközelítésben a bizalom a hit és várakozások összessége, arra vonatkozóan, hogy az üzleti partnerek a megállapodás szerint fognak cselekedni (DONEY, M. P. et al 1998). A kockázati oldalról történő megközelítés azt feltételezi, hogy a másik félnek is érdeke a megbízhatóság, az ígéreteinek megtartása. Ebben a megközelítésben a bizalomnak nagyobb jelentősége van olyan esetekben, ahol a kockázat mértéke is magasabb. A harmadik megközelítés pedig kifejezetten abból indul ki, hogy milyen károkat okozhat a bizalom hiánya (KUMAR, N. 1996).

Mivel a gazdasági cselekvéseket és eredményeket jelentősen befolyásolják a szereplők személyes kapcsolatai és a kapcsolati háló egészének szerkezete, magukban a klaszterekben is nagy szerepe van a korábbi személyes kapcsolatoknak és az ezeken alapuló ajánlásoknak (GRANOVETTER, M. 2005). A klaszterek müködéséhez szükséges bizalom megteremtését nagyban segítheti, ha az együttmüködések alapját korábbi üzleti vagy személyes kapcsolatok biztosítják, továbbá, ha a tagok személyes ajánlások révén kerülnek be az együttmüködésbe.

A klaszterek számos módon igyekeznek a bizalmi kapcsolataikat erősíteni és a meglévő erös bizalmi viszonyokat fenntartani. A bizalom megteremtéshez fontos, hogy partnerek minél jobban megismerjék egymást és a közös üzleti tranzakciók, projektek révén pozitív tapasztalatokat szerezzenek. A bizalom fenntartása érdekében a klasztereknek egyensúlyt kell elérniük verseny és együttmüködés között és igyekezniük kell elkerülni, hogy a tagok bármilyen módon visszaéljenek a klaszterben megszerzett piaci információkkal a saját érdekeik mentén (ANDERSSON, T. et al. 2004).

A fentiek alapján láthatjuk, hogy a klaszter együttmüködések, olyan speciális vállalati együttmüködések, ahol az együttmüködésböl származó előnyök nem kizárólag a földrajzi közelségböl adódnak. Az utóbbi néhány évtizedben felgyorsuló infokommunikációs fejlődésnek és a tudásalapú kapcsolatok speciális jellegének köszönhetően a klaszterek kapcsán a közelség más típusai is előtérbe kerültek, mely a közelség szerepének átértékelődését is eredményezte. A földrajzi közelség ugyan nem veszítette el a jelentőségét, de a klaszterek vizsgálata során már kiemelt figyelmet kell fordítani az együttmüködések kapcsolati térben való vizsgálatára is, hiszen a kapcsolati közelség nagyban hozzájárulhat a partnerek közötti együttmüködések elmélyüléséhez és az együttmüködéshez elengedhetetlen kölcsönös bizalom kialakulásához.

\subsection{Klaszterek szerepe az innovációs folyamatokban és a tudáshálózatokban}

Az innováció fogalmával először Schumpeter (1912) révén ismerkedhettünk meg és ez képezte alapját a későbbi innovációs elméleteknek is. Az ő elmélete szerint az innováció valamilyen új javak, termelési eljárások, piacok, beszerzési források vagy szervezet kialakítását jelenti (SCHUMPETER, J.A. 1912). A későbbiekben az innováció értelmezése egyre kiszélesedett és már nem csak egy lineáris, egymástól elszigetelt, egymást követő tevékenységek folyamataként értelmezhető, de sokkal inkább elterjedtek a nyílt és 
horizontális megközelítések. Lundvall (1992) értelmezésében az innováció már egy komplex interaktív tanulási folyamatként jelenik meg, ahol az innovációs folyamat fázisai közötti hatékony kapcsolat kialakítása és fenntartása szükséges, melyet Kline és Rosenberg (1986) visszacsatolásos lánc modellje is megerősít (LundVALL, B.A. 1992, KLINE S.J. - RosenBERG, N. 1986). Az OECD (2005) széles körben elfogadott definíciója alapján „Az innováció új, vagy jelentösen javitott termék (áru vagy szolgáltatás) vagy eljárás, új marketing-módszer, vagy új szervezési, szervezeti módszer bevezetése az üzleti gyakorlatban, munkahelyi szervezetben, vagy a külső kapcsolatokban”(OECD 2005). Az innováció mindenekelött a tudástermelő, tudáshasznosító és tudásközvetítő szereplők közötti regionális szintü interakciók eredménye (EUROPEAN COMISSION 2007). Az innováció tehát egy olyan interaktív fejlödési folyamat, amely megköveteli a szereplök közötti folyamatos kommunikációt és együttmüködést (TöDTLING, F. - TRIPPL, M. 2005).

A piaci verseny intenzitásának növekedésével az innovativitás már inkább a piacon maradás alapfeltétele, mintsem igazi versenyelőny a vállalatok számára, hiszen az innovációk száma dinamikusan növekszik, azonban ezáltal az előállított szellemi alkotások hasznosítása egyre nagyobb kihívássá válik az innovációs szereplők számára. (SZABÓ, K. - HÁMORI, B. 2006, BUZÁS, N. - PRÓNAY, Sz. 2013). Az innovációs kényszer megköveteli az együttmúködést a tudásteremtési folyamatban résztvevő más szereplőkkel. Ennek köszönhetően a vállalkozások egyre gyakrabban müködnek együtt más vállalkozásokkal, egyetemekkel, kutatóintézetekkel. $\mathrm{Az}$ együttmüködések révén könnyebben jutnak információhoz, a hiányzó technológiai szaktudáshoz, esetleg forráshoz, és a nemzetközi innovációs áramlásba is könnyebben be tudnak kapcsolódni. Ez egyszerre csökkentheti a $\mathrm{K}+\mathrm{F}+\mathrm{I}$ folyamatokhoz kapcsolódó rendkívül magas költségeket és bizonytalanságot. A vállalatok a szükséges kompetenciákat és erőforrásokat gyakran kívülröl a technológia transzfer kapcsolataik és a hálózatok révén szerzik meg. A tudás már nem a vállalatok egyéni szintjén jelenik meg, a tudásteremtési és átadási folyamatok már inkább a hálózatok szintjén zajlanak, mintsem elszigetelten a vállalkozásoknál (BUZÁs, N. 2005b). A vállalkozások és az egyéb innovációs szereplők ezért a versenyképességük megtartása érdekében hálózatokba tömörülnek. Az így kialakuló hálózati gazdaság a tudásalapú gazdaság egyik sajátos megjelenési formája (DINYA, L. 2008). A kapcsolatok tartalma és milyensége rendkívül nagy hatással van a gazdasági teljesítményre, de önmagukban nem a hálózatosodás javítja a klaszterek teljesítményét, hanem az értékes, tudásbővítő kapcsolatok megléte a klaszteren belül. A tudásalapú hálózatok tehát valóban pozitív hatással lehetnek a regionális gazdasági fejlődésre, hiszen ezen hálózatokban magasabb a jól teljesítő vállalkozások aránya. Fontos tehát annak megértése, hogy mely tényezők segítik ezen tudásalapú hálózatok kialakulását és ezek mennyiben vállalkozás vagy területspecifikus tényezők (GIULIANI, E. 2010). Guliani a klaszterek mögött húzódó hálózatok jellemzőit vizsgálva kétféle eltérő struktúrával rendelkező hálózattípust különböztetett meg: az üzleti hálózatokat és a tudáshálózatokat. Az üzleti hálózatok a cégek közötti interakciókon, a piaci-, társadalmi- és intézményi kapcsolatokon alapulnak és a klaszterek esetében szinte automatikusan alakulnak ki. Az üzleti hálózatok nagyon sokfélék lehetnek, fontos szerepük van a helyi tudás terjedésében, túlcsordulásában. Kialakulásukat olyan piaci interakciók segítik elö, mint például a szolgáltatások és termékek kereskedelme, közös konzorciumokban való részvétel, munkaeröpiaci kapcsolatok, ipari fórumokon, eseményeken való közös részvétel stb. A tudáshálózatok azonban olyan hálózatok, amelyek valamilyen komplex technológiai probléma megoldására irányulnak és az innovációhoz kapcsolódó tudás átadása révén kötik össze a vállalkozásokat (GIULIANI, E. 2010). A tudáshálózat tehát a problémamegoldás révén megvalósuló informális tudásátadásra épül a helyi szakemberek és vállalkozók között. A tudáshálózatok szerkezetileg is különbözőek, mely különbség abban rejlik, hogy míg az üzleti hálózatok átfogóak, összekapcsolva meglehetősen homogén módon a klaszter szinte teljes egészét, a tudáshálózatok ehhez képest kevésbé sürüek, szelektívebbek és a hálózaton belüli kapcsolatok eloszlása is jóval egyenlőtlenebb. A tudáshálózatoknak 
nagyobb hatása van a vállalkozások teljesítményére, mint az üzleti hálózatoknak (GIULIANI, E. 2010). A tudáshálózatokban csak korlátozott számú helyi szereplő vesz részt. A tudás a vállalkozások egy szük körében áramlik, mely vállalkozásokat magas innovációs teljesítmény és fejlett abszorpciós képesség jellemez. Számos olyan vállalkozás lehet, akik a földrajzi közelség és az üzleti hálózatban való részvétel ellenére, nem vesz részt a kapcsolódó tudáshálózat müködésében. A vállalkozások közötti földrajzi és kognitív közelség azonban nem jelenti automatikusan a tudásalapú kapcsolatok létrejöttét, ilyen jellegü kapcsolatok gyakran a nem helyi cégekkel alakulnak ki. (GIUliani, E. - BELL, M. 2005 BosCHMA, R.-TeR WAL, A. L. J. 2007).

A globalizációs folyamatok erősödése és a tudásalapú gazdaság elötérbe kerülése egyre inkább felértékeli a földrajzi koncentrációk jelentőségét (KRUGMAN, P. 2000), hiszen a globalizáció eredményezte új gazdasági trendek ellenére az innováció korántsem tekinthető globálisnak, vagyis határok nélkülinek. Éppen ellenkezőleg az innováció valójában egy olyan lokalizált jelenség, amely nagymértékben függ azoktól a forrásoktól, amelyek erősen helyfüggőek, bizonyos helyeken koncentrálódnak és máshol nem reprodukálhatók. Az innovációs folyamatoknál tehát előnyt jelent a térbeli közelség, hiszen hatékonyabb és gyorsabb a kommunikáció az innovációs szereplők között, ezáltal javul a probléma megoldási képesség, csökkenthető a technológiai bizonytalanság. Az úgynevezett rejtett vagy más néven tacit tudás átadásában nagy szerepe van a személyes kapcsolatoknak és a földrajzi közelségnek (Porter, M. E. - Sölvell, Ö. 1998, Lengyel, I. - DEÁK, Sz. 2002). A tudásalapú cégek horizontális kutatás-fejlesztési kapcsolatai az innovációs folyamat bonyolultságából adódóan és a tacit tudás átadásának speciális jellegének köszönhetően egyre több személyes kommunikációt igényelnek (LONGHI, C. - KEEBLE, D. 2000). A globális gazdaságban érzékelhető állandó innovációs versenykényszer arra ösztönzi a klasztereket, hogy egyre inkább a tudásalapú kapcsolatok előmozdítására törekedjenek és ez hosszú távon biztosíthatja a klaszterek helyét a térségek fejlesztésében (BUZÁs, N. 2000).

Az innováció a szereplők széles körének részvételével zajlik, mivel az egyes vállalkozások nem elszigetelten végeznek innovációs tevékenységet, hanem közben kapcsolatba lépnek más vállalkozásokkal, egyetemekkel, kutatóintézetekkel, különböző kormányzati és finanszírozási intézményekkel. Sőt azt is mondhatjuk, hogy az innovációs folyamatok a különböző szereplőkkel való interakciók révén fejlődnek. Ezek az interakciók történhetnek regionális vagy nemzeti szinten, a regionális és nemzeti innovációs rendszerekbe ágyazódva (BRESCHI, S. - MALERBA, F. 2005). Az innovációs folyamatokat számos tényező befolyásolja, és különböző intézményi és politikai keretrendszerben alakulnak ki, amelyek együttesen tekinthetők innovációs rendszernek. A regionális innovációs rendszerek magukban foglalják az adott régió $\mathrm{K}+\mathrm{F}$ szereplöit, innovatív vállalkozásait, egyetemeit, kutatóintézeteit, továbbá a technológiatranszfert támogató hídképző szervezeteket, a kapcsolódó regionális politikákat, $\mathrm{K}+\mathrm{F}$ ösztönzőket, de tágabb értelmezésben még a termelési, oktatási, pénzügyi és marketing rendszereket is, amelyek mind hozzájárulhatnak a tudás termelésén keresztül az innovációs folyamathoz. (INZELT, A. 1998, DöRY, T. 2000, LONGHI, C. - KEEBLE, D. 2000). Ebben az összefüggésben úgy tünik, hogy az innováció kevésbé az egyes vállalatok terméke, hanem inkább tekinthető a hálózatba szervezett intézményi és politikai keretrendszerek eredményének (KLINE, S.J. - ROSENBERG, N. 1986). A klaszterek a szektorális és a regionális innovációs rendszerekhez egyaránt szorosan kapcsolódnak, az innovációs rendszerek részeinek tekinthetőek, azokba beágyazódva müködnek. Egyfajta megközelítésböl a klaszterek maguk is felfoghatóak egyfajta szektorális innovációs rendszerekként A regionális innovációs rendszerek számos más az innováció szempontjából fontos szereplőt és több klasztert is magukba tömörítenek (TÖDTLING, F. - TRIPPL, M. 2008, WiXTED, B. 2009). 
Az alábbi 1. ábra jól szemlélteti, hogy Vas (2014) szerint „A klaszterek a nemzeti, regionális, szektorális és technológiai innovációs rendszerek keresztmetszetében, de akár azok határain túlnyúlva, a globális innovációs rendszerben jellemezhetöek” (VAS, Zs. B. 2014, 57. oldal).

\section{1. ábra Klaszterek az innovációs rendszerek keresztmetszetében}

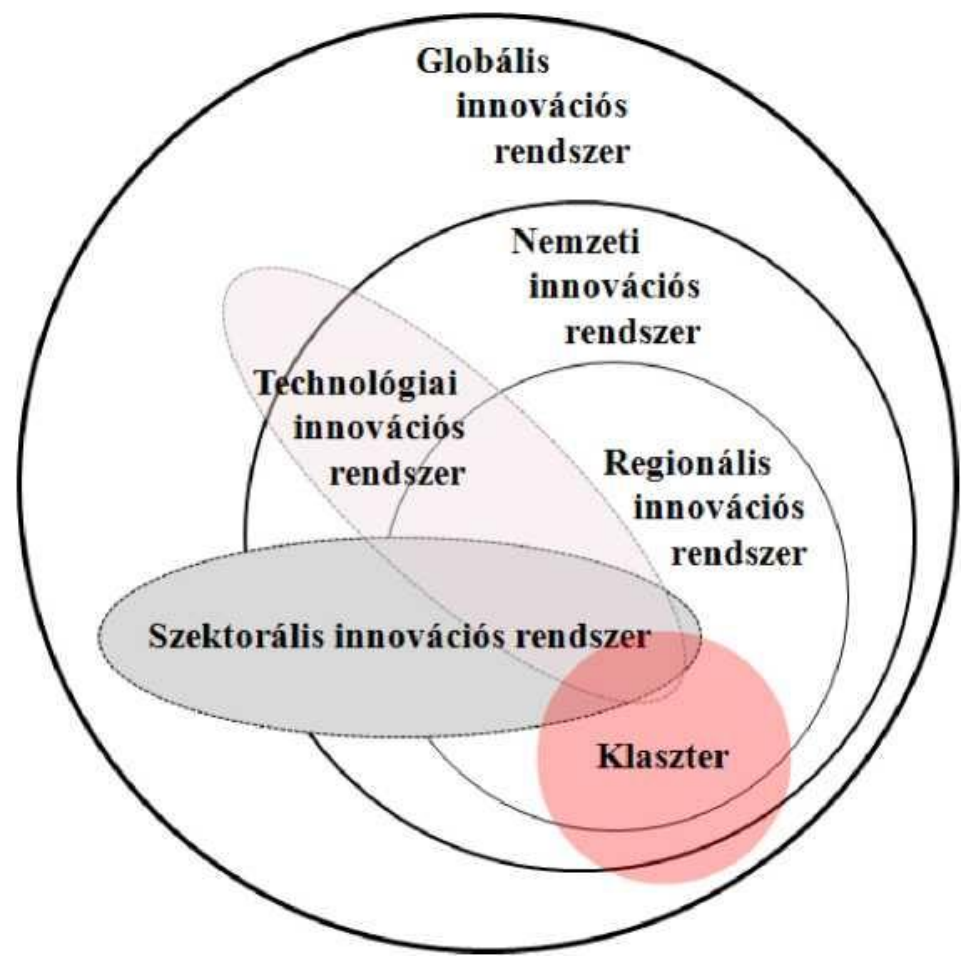

Forrás: VAS, Zs. B. 2014, 43. oldal

A klaszterek régiók versenyképességére gyakorolt hatásai közül elsősorban a termelékenység javulása, az innovációs kapacitások növekedése és az új innovatív vállalkozások megjelenése emelhető ki (COOKE, P. 2001). A klasztereken belül könnyebben valósul meg az innováció, hiszen magukban foglalják és a közös háttér és célok révén hatékonyan kapcsolják össze a Triple Helix innovációs modell legfontosabb szereplöit a tudományos, a gazdasági és a kormányzati szféra képviselöit (ETZKOWITZ, H. - LEYDESDORFF, L. 2000). A klaszterek közös fórumot teremtenek az oktatási, kutatási intézmények, valamint a vállalkozások számára és egy olyan innovációt támogató környezetet biztosítanak, ahol a résztvevők véleményt és információt cserélnek, közös projekteket valósítanak meg, és ezáltal hozzájárulnak a különböző szereplök közötti interakciók hiányából adódó innovációs szakadék áthidalásához, valamint az egyetemi szférában megtermelt tudás piaci környezetben történő alkalmazásához (KETELS, C. et al. 2012). Közelebb hozzák egymáshoz az innovációs szereplöket, megkönnyítik a köztük való kommunikációt, a tagok tanulhatnak egymástól és egyfajta húzóerőt gyakorolnak egymásra. A legfontosabb tudáscentrumok közelsége, nagyobb rálátást biztosít az új kutatási irányokra, javítja a költséges kutatás-fejlesztési erőforrások elérhetőségét és hozzájárul a tudás, különösen a hallgatólagos tacit tudás átadásához. A tudásátadás szempontjából kulcsfontosságú szakképzett személyzet toborzása és bevonása is könnyebbé válik. Az innovációt támogató környezet vonzóvá válik a külső befektetők, pénzügyi intézmények számára is, így a klaszterek révén a magas kockázatú költséges kutatás-fejlesztési tevékenységekhez szükséges pénzügyi források, pályázati pénzek, kockázati tőke elérhetősége is javul. A támogató és tudás-intenzív környezetben könnyebben alakulnak ki és fejlödnek az új, innovatív start-up és spin-off vállalkozások is (COOKE, P. 2001). A legfontosabb innovációs szereplök szervezett keretek között zajló együttmüködése 
nem csak a résztvevők versenyképességét javítja, de a tudástermelö régiók kialakulásához is hozzájárul (LENGYEL, B. 2005).

Mivel a vállalkozások versenyképessége szempontjából is egyre inkább elötérbe kerül az innováció jelentősége, nem meglepő, hogy a klaszterek sikerének is egyik fontos tényezőjeként kell tekintenünk a klasztereken belül megvalósuló innovációs folyamatokra. A klaszterek rendelkeznek a tudásteremtési, tudás átadási és hasznosítási folyamatokhoz szükséges feltételekkel, hiszen jellemzően a legfontosabb tudáscentrumok köré szerveződnek, magukban foglalják a meghatározó innovációs szereplőket, a földrajzi és kapcsolati közelség révén megfelelő légkört és színteret biztosítanak a tudásalapú együttmüködésekhez és nem utolsó sorban az innovációs folyamatokhoz szükséges pénzügyi erőforrásokat is hatékonyabban tudják biztosítani az együttmüködések révén.

\subsection{A klaszter együttmüködések szereplői, szervezeti háttér, szervezeti kultúra szerepe}

A klaszterek ugyan alapvetően vállalkozói együttmüködések, de a kis-és középvállalkozásokon (kkv-ken) túl számos további szereplőt is magukban foglalnak, úgy mint az egyetemek, kutatási intézmények, multinacionális vállalatok, pénzügyi szereplők, különböző önkormányzatok, kamarák, egyesületek. Minden szereplőnek megvannak a maga feladatai és motivációi az együttmüködésben.

A klaszterekben való részvétel a vállalkozások részéről komoly nyitottságot és szemléletformálást igényel, hiszen ezen együttmüködések legfőbb mozgatórugója a tudás és információk egymás közötti megosztása. Természetesen ez korántsem azt jelenti, hogy a vállalkozások minden szereplővel megosztják az üzleti titkaikat és technológiai újításaikat, de olyan stratégiai együttmüködéseket alakítanak ki, amelyekben az egymással megosztott információ, a közös teljesítmény javulása kellőképpen biztosítja az egyéni előnyöket is.

A hagyományos iparágak mellett a technológia intenzív iparágakban is egyre jobban a növekedés motorjává váltak a kis-és középvállalkozások (KEEBLE, D. - WILKINSON, F. 2000). A high-technológiai vállalkozások jelentősen innovatívabbak és gyakrabban valósítanak meg radikális technológiai innovációt, nemzetközi vagy globális piacokon végzik tevékenységüket, nagyobb valószínüséggel müködnek együtt más cégekkel és szervezetek és sokkal nagyobb arányban alkalmazzák a magasan képzett és magas jövedelmü szakmai, tudományos és menedzsment személyzetet (KEEBLE, D. - WiLKINSON, F. 2000). Az ezekben az iparágakban fontos versenyképességi tényezők a technológiai változás és az innováció azonban jelentős $\mathrm{K}+\mathrm{F}$ erőforrásokat igényel, amely erőforrások jellemzően a nagyobb cégekben összpontosulnak. A klaszterekben a kkv-k mellett a multinacionális vállalatoknak is nagy szerepe van. Ezek a cégek nagy érdeklődést mutatnak az európai csúcstechnológiai kkv-kkal való együttmüködés iránt, akár úgy hogy korai szakaszban befektetnek az ilyen jellegü start-up cégekbe, vagy szoros együttmüködésben, közös klaszterekben dolgoznak azokkal (Longhi, C. - Keeble, D. 2000). A kkv-k esetében sokszor nem áll rendelkezésre az innovációhoz szükséges technológiai vagy pénzügyi háttér, viszont sokkal rugalmasabbak és intenzívebb a tudás előállítási képességük. A multinacionális vállalatok ezzel szemben rendelkeznek a szükséges piaci információkkal, kutatási kapacitásokkal és finanszírozási forrásokkal, de a szervezet mérete és a hierarchikus, lassú döntéshozatal miatt az innovációs tevékenységük belső korlátokba ütközik. Az eltérő szervezeti adottságok és kultúra a szinergikus hatások kiaknázás révén megteremti a klaszterekben való együttmüködés alapját. A kkv-k számára tehát a multinacionális vállalatokkal való együttmüködés révén lehetőség nyílik a multinacionális vállalat beszállítójává válni, csatlakozni a vállalat fejlesztési irányaihoz, innovációs elképzeléseihez, valamint a közös innovációs tevékenység révén 
finanszírozási forrásokat és kapcsolatokat szerezni az ötleteik megvalósításához, piacra viteléhez (Kocsis, A. 2012). A multinacionális vállalatok jelenléte a fentieken kívül javíthatja a klaszter egészének ismertségét és hírnevét, azonban a lassú, nehézkes döntéshozatala és a szervezeti rugalmatlansága révén meg is nehezítheti a klaszterben folyó tevékenységeket.

A tudásintenzív klaszterekben nagy szerepe van az egyetemeknek, főiskoláknak, kutatási intézményeknek az általuk megtermelt tudás és annak piacosítása révén. Az egyetemek jellemzően az alap- és alkalmazott kutatási feladatokban vesznek részt, de arra is számos példa van, hogy a konkrét technológiai problémák megoldására irányul az együttmüködés (ANDERSSON, T. et al. 2004). Az egyetemeken jelentős K+F kapacitások, szakképzett kutatók, értékes tudományos müszerpark áll rendelkezésre és az elmúlt időszakban egyre nagyobb szemléletváltás következett be az egyetemi szakembergárda hozzáállásában. Felismerték, hogy a szerepük már túlmutat a hagyományos oktatási és kutatási feladatokon és az itt megtermelt piacképes tudás gyakorlatba történő átültetésében, a létrehozott szellemi alkotások piacosításában is hatékonyan részt kell venniük. Ezt nevezik az egyetem harmadik missziójának (LUKOVICS, M. 2005, VILMÁNYI, M. 2011). A vállalkozások ezzel párhuzamosan belátták, hogy a $\mathrm{K}+\mathrm{F}+\mathrm{I}$ tevékenységeiket nem feltétlenül tudják házon belül megoldani és az egyetemi szféra felé való nyitás új lehetőségeket tartogat a számukra.

A klaszteresedés rámutat az úgynevezett hídképző intézmények jelentőségére, akik nagy szerepet játszanak a vállalkozások közötti kapcsolatok kialakításában, a tudás teremtő és a tudást piaci alapon alkalmazó szervezetek közötti rés kitöltésében. A klaszterfejlesztési politikák alapelvei között a pénzügyi támogatások mellett előtérbe kerültek a tudás előállító és hasznosító szereplők közötti kapcsolatokat támogatni képes szereplők, úgynevezett „brókerek” vagy „clusterpreneur”-ek szerepe (ANDERSSON, T. et al. 2004). Ezek a személyek többféle kompetenciával rendelkeznek (pl. facilitálási, elemzési, kapcsolatépítési) és képesek elösegíteni a klaszteren belüli együttmüködések sikerét, szinergiák kialakulását azzal, hogy ismerik a klaszteren belüli szereplöket és hatékonyan tudják öket összekapcsolni. Ezen szereplök sok esetben nem egyedül, hanem egy csapattal, háttérintézménnyel végzik a tevékenységeiket, akár a klasztermenedzsmenten belül, vagy azon kívül (ANDERSSON, T. et al. 2004).

A klaszter sikerességét meghatározza a klasztermenedzsment szervezet szakértelme, felkészültsége, hozzáállása. A menedzsmentnek nagy szerepe van az együttmüködésekhez szükséges bizalmi kapcsolatok kialakításában és erősítésében, a tudástermelési és átadási folyamatok előremozdításában valamint a klasztereken belül fellépő információs akadályok elhárításában (SASS, M. - SZANYI, M. 2009, Buhl, C. M. - KÖCKER, G. M. 2009). A klasztermenedzsment szervezetek különböző formában müködnek a nonprofit szervezetektől, a közintézményéken át a gazdasági társaságokig. A klaszterekben részt vevő vállalkozásoknak és egyéb innovációs szereplőknek hatékony, professzionális és személyre szabott szolgáltatásokra van szüksége, a klaszter nyújtotta előnyök maximális kihasználása érdekében. A hatékony, professzionális klasztermenedzsment szervezetek kritikus fontosságúak az üzleti támogató szolgáltatások minőségének növelése és a klaszterkezdeményezések önfenntartóvá válása szempontjából (EUROPEAN COMMISSION 2008).

A klaszterekben megvalósuló hatékony együttmüködést sokszor hátráltatja, hogy a különböző szereplők eltérő érdekrendszer, motiváció vagy szervezeti-döntéshozatali rendszer mentén működnek. A szervezetek közötti együttmüködéseket a helyi tényezők és gazdasági rendszer hatásain túl maga a cégek mögött álló vezetési, irányítási rendszer és folyamatok is erőteljesen befolyásolják (DICKEN, P. - MALMBERG, A. 2001). Az eltérö irányítási 
rendszerek, belső motivációk sokszor akadályozó tényezőként jelenhetnek meg, mely a gyakorlatban föként a multinacionális vállalatok központosított és lassú döntéshozatali rendszerében, vagy az egyetemek rugalmatlan, hierarchikus és publikáció-orientált magatartásában figyelhető meg. Ezeket a problémákat a klaszter vezetőinek időben fel kell ismerniük és meg kell próbálniuk az eltérő érdekeket összehangolni vagy kezelni az abból adódó sajátosságokat.

Tödling és szerzőtársai (2006) egy átfogó képet adnak arról, hogy az egyes területi szintek tudáselosztásban és innovációs folyamatokban betöltött szerepe szerint milyen típusú kapcsolatok jöhetnek létre a szervezetek között. A 2 dimenzió mentén a formális és informális, továbbá az eseti vagy statikus és a dinamikus folytonos kapcsolatokat különböztettek meg. Ez alapján 4 fö kapcsolati formára hívták fel a figyelmet (TöDTLING, F. et al. 2006):

1. Piaci kapcsolatok, melyek egy konkrét technológia vagy kodifikált tudás átadására, megvásárlására vonatkoznak.

2. A helyi ismeretek, tudás átterjedése azt a folyamatot jelzi, amikor a tudás és az ismeretek az egyetemektől és a kutatási szervezetektől átterjed a cégek irányába, például a mobil munkaerő vagy az informális kapcsolatok révén. Ilyenkor a tudáscsere mögött nem áll semmilyen hivatalos szerződés vagy ellentételezés.

3. A hálózatok, melyek a piaci kapcsolatokhoz képest tartósabbak és az innovációs folyamat egyes szereplőinek interaktív kapcsolatára épülnek. A hálózatokban nem csak a különböző technológiák vagy ismeretek cseréje, de a megfelelő tudásbázis további fejlesztése és bővítése is megvalósul. Ez egy dinamikus kollektív tanulási folyamatot eredményez.

4. Innovációs miliő: $\mathrm{Az}$ innovációs hálózatok tartalmazhatnak informálisabb kapcsolatokat és együttmüködéseket is a vállalatok és szervezetek között, például az ipari körzetekben és a csúcstechnológiai régiókban. Ezek alapja a bizalom, a problémák és célok megértése, valamint a közös szabályok és viselkedési normák elfogadása. Ez a társadalmi tőke, specifikus innovatív környezetet, miliőt eredményez, melynek kulcsa az ötletek és a tudás gyors cseréje, továbbá a kollektív tanulás. Az innovatív miliő jellemzően egy adott helységhez vagy régióhoz kötődik, mivel a személyes kapcsolatok biztosítják az alapját.

A 3. 4. kategória fogalmilag különböznek az első két kategóriától. Ezek gyakran evolúciós vagy szociológiai megközelítések, érvelések, melyek túllépnek a tranzakciós költség logikáján (TöDTLING, F. et al. 2006).

A klaszter vezetésének és szervezeti kultúrájának szerepével kapcsolatos összefüggéseket Lippert (2015) kutatta és megállapította, hogy szignifikáns kapcsolat mutatható ki a klaszter vezetésére jellemző domináns szervezeti kultúra és domináns vezetői szerep, valamint a klaszter érettségi indexével jellemzett sikere között. Két olyan szervezeti kultúra van, amely hatékonyabban járul hozzá a klaszter sikeréhez, mint a többi. Ezek pedig a domináns piac és a domináns adhokrácia szervezeti kultúrák.

Az adhokrácia esetében az innováció egyfajta összetartó erő, ezért erre a szervezeti típusra a dinamizmus, a kreativitás és a nyitott gondolkodás jellemző. Mivel a hosszú távú célok között a növekedés és az új erőforrások kiemelten fontosak, a sikertényezök között is elökelő helyen szerepel az új termékek és szolgáltatások bevezetése. Az ilyen típusú szervezetek vezetőire jellemző, hogy támogatják az egyéni kezdeményezéseket, vállalkozó, újító, kreatív típusok, akik kiemelkedő jövőbelátó képességgel rendelkeznek (LIPPERT, R. 2015).

A piac típusú szervezeteket a céltudatosság, hatékonyság és eredményorientáltság jellemzi. A sikertényezők között a piaci részesedés, a nyereségesség és a tőke kiemelten fontosak. Az ügyfélközpontúsággal, az erős partneri kapcsolatokkal és a termelékenység 
javításával igyekeznek versenyelőnyt szerezni a piacon. A vezetők jellemzően nagyon célorientált és határozott típusú személyek (LIPPERT, R. 2015).

A vezető szerepeket tekintve a domináns mentor és direkor típusú vezetők hatékonyabban járulnak hozzá a klaszter sikeréhez, így a klasztervezetők esetében föként ehhez a két szerephez tartozó kompetenciák fejlesztése kívánatos.

A mentor típusú vezetők jellemzően nagyon empatikusak, akik tisztában vannak a saját- és mások igényeivel, képességeivel és nagy hangsúlyt fektetnek a dolgozóik fejlesztésére. A bizalom és a kölcsönös tisztelet nagyon fontos számukra és kommunikációjuk is nagyon hatékony. A direktor típusú személyek határozott vezetők, akik kellöen hatékonyak a jövőkép alkotásában, a célok kitüzésében, szabályok és irányelvek alkotásában. A folyamatok megfelelö tervezése, szervezése, majd ellenőrzése, a problémák azonosítása és megoldása fontos a számukra (LIPPERT, R. 2015).

A klaszteresedés és a nemzeti kultúra összefüggéseit Ábrahám és szerzőtársai (2010) vizsgálták és megállapították, hogy a létezik kapcsolat a nemzeti kultúra és a tudásorientált klaszteresedettség között. Két kulturális tényező a bizonytalanságkerülés és jövőorientáció kultúraváltozója mutat pozitív kapcsolatot a tudásorientált klaszterek elterjedtségével. A jövőorientáció a tudásintenzív klaszterek esetében főként a hosszú távú tervezés lényegességét, a jövőbe, vagyis az innovációba való befektetés fontosságát mutatja, míg a bizonytalanságkerülés a klaszteres együttmüködések révén elérhető kockázatcsökkentéssel hozható összefüggésbe (ÁBRAHÁM, Zs. et al. 2010).

A klaszterek több különböző típusú, eltérő célokkal, szervezeti kultúrával, működési struktúrával rendelkező szervezetet foglalnak magukban, így azok sikeréhez meg kell ismerni és érteni a szereplők eltérő motivációit, szervezeti jellemzőit, döntéshozatali rendszerét és ehhez alkalmazkodva kell a lehető leghatékonyabb együttmüködést kialakítani. Ez sokszor nehéz folyamat és nagy felelősség hárul a klaszterek vezetöire és a klaszter menedzsment szervezetekre. Többek között ezért is került az elmúlt évtizedben a klaszterek irányítása és menedzsmentje a klaszteres elemzések és fejlesztések fókuszába, hiszen a professzionális klaszter menedzsment szervezetek nagyban meghatározhatják és előmozdíthatják egy klaszter hosszú távú sikerességét.

\subsection{A klaszterek sikerességének alapfeltételei, a klaszterek fenntarthatósága}

A klaszterek sikeres müködése mögött számos kulcsfontosságú tényező áll. Vannak olyan alapfeltételek, amelyek nagy része a legtöbb klaszter esetében azonosítható. Andersson és szerzőtársai a Klaszterpolitikák Fehér Könyvében az alábbi hét kulcstényezőt emelte (ANDERSSON, T. et al. 2004):

1. A földrajzi koncentráció már a kezdetektől a klaszterek fogalmának központi elemeként szerepelt. Napjainkban ugyan egyre több megközelítés megkérdőjelezi a fizikai közelség fontosságát, azonban mind az olyan kemény tényezők, mint a külső méretgazdaságosság, mind az olyan puha tényezők, mint a társadalmi töke és a tanulási folyamatok is azt indokolják, hogy a földrajzi közelség még mindig a klaszter koncepció egyik fontos tényezője maradjon.

2. Specializáció: A klaszterek szakterületüket tekintve jellemzően egy olyan alaptevékenység köré koncentrálódnak, amelyhez minden szereplő tud kapcsolódni. Persze a specializáció jellege nem feltétlenül korlátozódik egy ágazatra, sőt az alaptevékenység köré épülve gyakran alakulnak ki szektoron átívelö együttmüködések a klaszterekben. 
3. Változatos összetétel: A klaszterek nem csak cégekböl állnak, de az együttmüködésbe bevonódnak a legfontosabb tudományos szereplők, egyetemek, kutatóintézetek, kapcsolódó szövetségek, hatóságok, pénzügyi intézmények is.

4. Verseny és együttmüködés: Az egymással bizonyos területeken együttmüködö és más területeken versengő vállalkozások közötti kapcsolatok adják a klaszter dinamikáját. Az együttműködésből és információcseréből származó előnyök meghaladják az ezek kapcsán felmerült költségeket. A versenyhelyzet pedig jobb teljesítmény elérésére ösztönzi a szereplöket.

5. Kritikus tömeg: Annak érdekében, hogy kialakuljon a klaszter hatékony müködéséhez szükséges belső dinamika, a klaszterben szereplő szervezetek számának el kell érnie egy bizonyos kritikus tömeget.

6. A klaszter életciklus: A klaszterek nem ideiglenes rövid távú jelenségek, hanem hosszú távú perspektívát kínálnak az együttmüködésre, így az idő múlásával van egyfajta irányuk és belső stabilitásuk és az életciklusukat tekintve is több fejlödési szakaszon haladnak keresztül.

7. Innováció: Az együttműködések révén elérhető technológiai, szervezeti változások, innovációt ösztönző tényezők nagy jelentőséggel bírnak a klaszterek által kínált elönyök megteremtésében.

A fenti lista tekinthető talán az egyik legszélesebb körünek a tényezők számát tekintve, más szerzők is nagyjából hasonló eredményekre jutottak a vizsgálataik során.

Izsák és szerzőtársai (2016) a Smart guide to cluster policy c. dokumentumban a fentiekhez hasonlóan, a kritikus tömeg, a kapcsolódó iparágak jelenléte, a helyi, lokális tényezők, továbbá a kapcsolatok és bizalom fontosságára hívták fel a figyelmet (IZSAK, K. et al. 2016). Ketels 2017-es munkájában is a kapcsolódó iparágak és méretgazdaságosság, földrajzi közelség, együttmüködés, valamint a kritikus tömeg fontosságát emelte ki, mint a klaszterek kulcsdimenzióit (KETELS, C. 2017). Egy Horváth és szerzőtársai által 2013-ban összeállított magyarországi klasztereket vizsgáló tanulmány a fenti tényezőkön túl még a profi klasztermenedzsment szerepét emelte ki, mint a sikerességhez szükséges alapfeltételt HORVÁTH, M. et al. 2013).

A fentieken túl a klaszterek sikeressége szempontjából fontos a klaszterek hosszú távú pénzügyi stabilitása és fenntarthatósága. A klaszterek müködése ugyanis általában jelentős költségekkel jár, melyek közül az egyik legjelentősebb tétel a külön erre a célra szakosodott klasztermenedzsment fenntartása, müködtetése. A klasztermenedzsment szervezet költségei között értjük a béreket, szakértői díjakat, adminisztratív és marketing költségeket, továbbá a klaszteren belüli rendezvények, találkozók megszervezésének, lebonyolításával kapcsolatos kiadások. Ezen felül nyilván plusz kiadást jelent egy-egy célirányos képzés vagy tanácsadás, továbbá a nemzetközi szakmai vásárokon, kiállításokon való megjelenés is.

A klaszter költségeinek finanszírozása jellemzően az alábbi forrásokból valósul meg:

- A klasztertagok által fizetendő egyszeri vagy rendszeres pénzügyi hozzájárulásokból, ami jellemzően éves tagdíjat jelent.

- Szolgáltatási díjakból származó bevételek, melyek a klaszter által külső szervezetek számára nyújtott szolgáltatások ellenértékét jelenti.

- Külső források bevonása, melyek általában valamilyen pályázati forrást jelentenek.

Ezek a bevételi források változatás formákban jelennek meg a klasztereknél, de összességében elmondható, hogy a klaszterek nagy része még nagyobb részt külső pályázati forrásokból finanszírozzák a tevékenységüket és csak kisebb mértékben jelennek meg a szolgáltatási bevételek a bevételi források között. Egy 2013-ban lefolytatott klaszteres felmérés alapján a klaszterek finanszírozásában a külső források (nemzetközi, nemzeti és regionális/lokális források) aránya 54 \%, míg a külső szolgáltatásokból származó bevételek 
csak $8 \%$-ot, a tagdíjakból származó bevételek pedig 26 \%-ot tesznek ki (KETELS, C. et al 2013).

A klasztertagok által fizetendő tagdíj nagysága klaszterenként változó és számos esetben akár klasztertagonként is eltérő lehet, illeszkedve annak méretéhez, vagy szervezeti formájához. A klaszter finanszírozása szempontjából a klaszter összetételének és ezen belül is a nagyvállalatoknak fontos szerepe van, hiszen sokszor ők biztosítják a müködéshez szükséges források nagy részét. A klaszterek hosszú távú finanszírozása és fenntarthatósága szempontjából fontos, hogy a tagdíj mértéke megfelelően legyen meghatározva és arányban álljon azokkal az anyagi és nem anyagi természetü előnyökkel, amelyekhez cserébe jutnak tagok. A túl magas tagdíj elriaszthatja a kis -és középvállalkozásokat, azonban egyfajta eszközként is szolgálhat, a kizárólag a pályázati források iránt érdeklődő, vagy inaktív klasztertagok kiszürésére. A túl alacsony tagdíj veszélye viszont, hogy nem biztosítja a klaszter müködtetésével kapcsolatos költségeket (SZANYI, M. 2008).

A fenntarthatóság szempontjából fontos bevételi lehetőséget jelentenek a klasztereknek a klasztermenedzsment által a külső piaci szereplők számára nyújtott szolgáltatások. Ehhez azonban egy felkészült, jól képzett menedzsmentre van szükség, akik nem csak a saját klasztertagjaik számára képesek értéket közvetíteni, de piacképes, eladható tudással is rendelkeznek. A klaszterek szempontjából nyilvánvalóan ez a finanszírozási forma lenne a legideálisabb, azonban a fent felsorolt források közül talán ez az egyik legnehezebben megszerezhető. Magyarországon erre csak nagyon kevés jól müködő példát találunk (HORVÁTH, M. et al. 2013).

A klaszterek finanszírozási szerkezetében, föként Magyarországon az elmúlt években nagyon nagy arányt képviseltek a külső, európai uniós és állami támogatások. Ez azonban több szempontból is aggályos. Egyrészről mivel nem biztosítja, hogy csak olyan klaszterek jöjjenek létre, amelyek hosszú távon, piaci körülmények között is megállják a helyüket, kvázi piactorzító hatásuk van. Másrészről pedig ezek a források végesek, tehát a kizárólag a pályázati pénzeknek köszönhetően létrejött és müködő klaszterek, nagy valószínüséggel nagyon hamar megszünnek vagy passzívvá válnak a források elmaradásával. A legfontosabb szempont tehát, hogy olyan tagösszetételt, müködési struktúrát és finanszírozási szerkezetet alakítsanak ki maguknak a klaszterek, amelyekkel hosszú távon nem csak fennmaradni, de akár fejlődni is tudnak.

Az európai uniós támogatási rendszerében már felismerték a pénzügyi források piactorzító jellegét és egyre inkább előtérbe kerültek a nem anyagi jellegü ösztönzők, a klaszterek részére nyújtott tanácsadások, képzések, egyéb szolgáltatások. Ezek közvetlenül nehezen számszerüsíthetőek, mégis hatékonyan elö tudják mozdítani egy klaszter versenyképességét, de nyilván csak azokét, akik a támogatások nélkül is megállnák a piaci környezetben a helyüket (MEIER ZU KÖCKER, G. - MÜLLER, L. 2015).

A klaszterek sikeres müködéséhez és önfenntartóvá válásához szükség van egy minimális taglétszámra, vagy kritikus tömegre, amely biztosítja az együttmüködésből származó előnyök hatékony kihasználását és a klaszter további fejlödését. Szanyi (2008) úgy véli, hogy Magyarországon a klasztereknek a müködésüket 3 éven belül a külső támogatások folyamatos csökkentése mellett, a klasztertagdíjakból és a szolgáltatási díjakból kellene fedezniük, melyhez a klasztereknek el kell érniük a finanszírozási szempontból is fontos kritikus tömeget. Ez a kritikus tömeg számos klaszterspecifikus tényezőtől függ és akár a különbözö ágazatokban is eltérő lehet (SZANYI, M. 2008).

Lukács (2013) kutatásaiban szintén arra kereste a választ, hogy hogyan válhatnának hosszú távon fenntarthatóvá a klaszterek és hogy mekkora egy adott klaszter „kritikus tömege” vagyis mi az a ,legkisebb fenntartható klaszter-méret, amely legelöször biztositja a térbeli 
közelségböl és a szereplök megfelelö számából adódó hozadékok (pozitív extern hatások és dinamikus agglomerációs elönyök) megjelenését” (LUKÁCS, A. 2013, 10. oldal)

Munkája során kidolgozott egy klaszter-fenntarthatósági modellt, amely a Magyarországon müködő klaszter-kezdeményezések kritikus tömegének beazonosítására alkalmazható, és amely gazdaság-matematikai modell összekapcsolja a klaszterek legfontosabb sikertényezőt, köztük a finanszírozási struktúrát, a klaszter méretét és fenntarthatóságát.

A modell szerint a klaszter finanszírozási szempontból akkor tekinthető hosszú távon fenntarthatónak, ha teljesül az alábbi feltétel:

$$
J \cdot\left(m_{I}-t_{J}-s_{J}\right)+I \cdot\left(m_{I}-t_{I}\right) \leq g \cdot \bar{M} \cdot \operatorname{Pr}\left(\mathrm{j}_{\mathrm{g}}, \mathrm{i}_{\mathrm{g}}\right)
$$

ahol,

J: a klaszterben müködő produktív tagok

I: a klaszterben müködő improduktív tagok

$m_{I}:$ Az improduktív tagok éves forrásigénye

$m_{J:}$ A produktív tagok éves forrásigénye

$t_{J}$ : A produktív tagok éves tagdíjának nagysága

$t_{I}:$ Az improduktív tagok éves tagdíjának nagysága

$s_{J}:$ A szolgáltatásnyújtásból realizált jövedelmek

nagysága g: A klaszteren belül alakult projektcsapatok száma

A projektcsapatokban $j_{g}$ és $i_{g}$ produktív és improduktív klasztertag vesz részt

$\bar{M}$ : A pályázatíró csoportok által éves szinten átlagosan elnyert pénzösszeg

$\operatorname{Pr}\left(\mathrm{j}_{\mathrm{g}}, \mathrm{i}_{\mathrm{g}}\right)$ : Annak a valószínüsége, hogy az egyes csapatok mekkora eséllyel nyernek az általuk benyújtott pályázattal.

Modelljében a fentiekhez hasonlóan a legfontosabb bevételi forrásként a tagdíjak, pályázati források és a külső szolgáltatásnyújtásból származó jövedelmek jelennek meg. Véleménye szerint a magyarországi klaszterek nagy része túlságosan függ a külső forrásoktól, a közös $\mathrm{K}+\mathrm{F}+\mathrm{I}$ tevékenységük nem eléggé hatékony és nem rendelkeznek azzal a klaszter taglétszámmal és szerkezettel, ami biztosítaná a klaszter hosszú távú fenntarthatóságát (LUKÁCS, A. 2013).

A klaszterek sikerességét és hosszú távú fenntarthatóságát vizsgálva megállapíthatjuk, hogy van néhány olyan tényezö, amelyek nem minden esetben jelentenek garanciát a klaszterek eredményes müködéséhez, de jelenlétük alapvetően szükséges a klaszterek müködéséhez. Ilyen alapfeltételek a földrajzi közelség, a klaszterek megfelelő és változatos összetétele, a tagok közötti együttmüködési dinamika és kölcsönös bizalom kialakulása, a közös szakmai háttér és célok és az ezt támogató professzionális menedzsment háttér megléte. Ezen alapfeltételeken túl még a sikeresség kulcsát jelenthetik a klaszteren belül megvalósuló innovációs tevékenységek és a hosszú pénzügyi távú fenntarthatóságot biztosító anyagi források megléte. 


\section{KLASZTEREK AZ EURÓPAI UNIÓBAN}

A klaszterek kialakulása egy hosszú folyamat, amelyet számos tényező akadályozhat, és amely folyamat célzott gazdaságpolitikával tudatosan ösztönözhetö. Különösen nagy jelentősége van ennek a perifériás térségekben, ahol az akadályozó tényezők nagyon nagy számban vannak jelen. Az Európai Unió is viszonylag korán felismerte a klaszterekben rejlő lehetőségeket és a klaszterek célzott támogatása már az 1990-es években megjelent mind az Európai Unió szintjén mind az egyes tagországokban, de a 2000-es évek elejétől még intenzívebbé és célzottabbá váltak a klaszterfejlesztési politikák és programok. Az unió számos politikájában megjelentek a klaszterekkel kapcsolatos célok, ajánlások és egyre több klaszterprogram indult el, különböző intézmények, szövetségek jöttek létre, a klaszterpolitikákban megfogalmazott célok és ajánlások végrehajtása érdekében. A 20072013-as programozási időszak a pénzügyi források tekintetében is nagyon intenzív időszak volt, uniós és nemzeti szinten egyaránt számos program ösztönözte az induló és a fejlődő klaszter (GIULIANI, E. 2010) együttmüködéseket, míg 2014-től már sokkal koncentráltabbá váltak ezek a támogatások és a fókusz inkább a világszínvonalú klaszterek fejlesztésére helyeződött át.

Az alábbi fejezetben azt kívánom röviden összefoglalni, hogyan jelennek meg a klaszterek az Európai Unió politikáiban és milyen klaszteres programok, támogató intézmények jöttek létre az elmúlt bő egy évtizedben. A klaszterek teljesítményének és eredményességének mérésére kialakult gyakorlatok közül is bemutatok néhányat, továbbá az utolsó két alfejezetben a klaszterprogramokban tapasztalható változásokra és a klaszter menedzsment szervezetek kiemelkedő szerepére és kihívásaira szeretném felhívni a figyelmet.

\subsection{Klaszterek az Európai Unió politikáiban és támogatási rendszerében}

A klaszterpolitika révén a politikai döntéshozók új klaszterek kialakulását és meglévő klaszterek növekedésének felgyorsítását vagy újratervezését kívánják elérni, a klaszterek számára kedvező feltételeket biztosításával. A klaszterpolitikák igen széleskörüek, hiszen vannak kifejezetten a klaszterek közvetlen fejlesztésére irányuló politikák, de ide sorolhatjuk azon politikákat is például gazdaságpolitika, oktatáspolitika vagy innovációs politika, amelyek hatással vannak a klaszterben müködő szervezetekre és a köztük való együttmüködésre. A Klaszterpolitikák Fehér Könyvében Andersson és szerzőtársai (2004) a különféle beavatkozási politikákat többféle csoportra osztják. Ilyen kategóriaként azonosítják a bróker politikákat, amelyek a klaszterekben részt vevő különféle érdekelt felek közötti párbeszéd és együttmüködés keretrendszerének erősítését támogatják és nem az egyes szereplöket. Ennek eszközei lehetnek például a különböző kompetencia központok, ipari parkok, inkubátorházak. A keresletoldali politikák az állami megrendelések és közbeszerzések révén tudják ösztönözni a klasztereket, bár ezt a területet sok egyéb szabályozás is köti. A képzési politikák olyan készségek és kompetenciák fejlesztésére irányulnak, amelyek nélkülözhetetlenek a kkv-k hatékony együttmüködéséhez. A nemzetközi kapcsolatok kialakulását támogató intézkedések a külföldi és belföldi szereplők közötti együttmüködéseket kívánják megkönnyíteni például a kommunikációs és közlekedési rendszer fejlesztésével, vagy a tudás és a külföldi müködő tőke áramlását akadályozó tényezők kiküszöbölése révén. Végül ide sorolhatjuk a különböző keretpolitikák szerepét is, hiszen olyan szélesebb keretfeltételek is befolyásolják klaszterek sikerét, mint a makrogazdasági stabilitás, a jól működő piacok szerepe, a kommunikációs és közlekedési infrastruktúra, az oktatás, de akár társadalmi tőke és a bizalom támogatását célzó intézkedések is (ANDERSSON, T. et al. 2004). 
A klaszteres politikák végrehajtása több szinten valósul meg, történhet lokális, vagy regionális szinten, de az egyes országok, makrorégiók és maga az Európai Unió is több klaszterekre összpontosító programokat indítottak. A szövetségi berendezkedésü államokban a klaszterpolitika kidolgozása és végrehajtása általában regionális szinten történik ezért a célok és eszközök gyakran különböznek régiónként. Az olyan országokban, mint például Olaszország, Spanyolország, Németország és Belgium nincs egységes szintü nemzeti klaszterpolitika, a klaszterpolitika regionálisan meghatározott. Bizonyos országok, mint például Dánia, Franciaország, Hollandia, Portugália és az Egyesült Királyság viszont többékevésbé elkülönült nemzeti klaszterpolitikával rendelkezik (ISAKSEN, A. - HAUGE, E. 2002, KETELS, C. 2004). A célzott klaszterpolitikák igen költségesek és kockázatokat is lehetnek, hiszen torzíthatnak bizonyos természetes alkalmazkodási folyamatokat, illetve nagy felelősség a döntéshozók részéről megtalálni a megfelelően hatékony eszközöket a klaszterek fejlesztésére. A klaszterek fejlesztését célzó programok azon intézkedéseket, finanszírozási forrásokat foglalják magukba, melyeknek célja a klaszterek létrehozása, erősítése, a klaszterek közötti kapcsolatok ösztönzése. A programok végrehajtása különböző minisztériumokban, innovációs ügynökségekben, vagy külön erre a célra létrehozott intézményekben, szervezetekben valósul meg (ANDERSSON, T. et al. 2004).

Az Európai Unió szintjén már az 1990-es évek vége óta léteznek explicit klaszterpolitikai programok, melyek a klaszterek innovációs kapacitását és versenyképességét hivatottak előmozdítani. Az Európai Bizottság különféle klaszter- és innovációs politikai eszközöket biztosít a különböző föigazgatóságok közremüködésével. A klaszterekhez köthető intézkedések és kezdeményezések végrehajtásáért jellemzően a Regionális Politika Főigazgatóság, a Belső Piaci, Ipar-, Vállalkozás- és Kkv-politikai Főigazgatóság (korábbi Vállalkozás és Ipar Főigazgatóság) és a Kutatási és Innovációs Főigazgatóságok felelősek. Az Európai Bizottság mellett a tagországok nagy része is rendelkezik önálló klaszterpolitikával, azonban a klasztereket támogató programok és eszközök még nem egységesek uniós szinten, hanem országonként eltérőek.

A klaszterpolitikáktól és klaszterprogramoktól meg kell különböztetni a klaszter kezdeményezéseket, amelyek olyan szisztematikus erőfeszítések, amelyeknek célja a klaszterek létrehozása, befolyásolása, fejlesztése. Ezek a kezdeményezések kialakulhatnak alulról jövő módón, de akár felülről koordináltan is. A klaszterkezdeményezésekben nagy számban vesznek részt gazdasági szereplők, müködésük ennek ellenére sokszor nagymértékben függ a közforrásoktól. Koordinálásukban kiemelkedő szerepe van a korábban klaszter brókereknek, vagy clusterprenuer-eknek nevezett szereplőknek, szervezeteknek, melyek jelenleg már sok esetben önálló klaszter menedzsment szervezetekké fejlődtek (KETELS, C. et al. 2013). A klaszter menedzsment szervezetek szerepére és müködésére az 3.4-es fejezetben térek ki részletesebben.

Az Európai Unió 2006-os innovációs stratégiája kiemeli azokat a versenyképességi előnyöket, amelyeket a klaszterek kínálnak a tagjaik számára, mely szerint a közös klaszterhez tartozás az üzleti versenyképesség meghatározó tényezője, mivel a klaszterek segítségével felgyorsul a tudás piacra kerülése és csökken az ipar és a tudomány közötti szakadék. A klaszterek javítják továbbá a termelékenységet, vonzzák a tőkét, erősítik kutatási tevékenységet és az együttmüködéseket, továbbá a képességek fejlesztésének centrumaivá válnak (EURÓPAI KÖZÖSSÉGEK BIZOTTSÁGA 2006).

A 2008-ban elkészült Európai Klasztermemorandum az európai innovációs rendszerek klaszterek támogatásán keresztüli előremozdítását tüzte ki célul. A memorandum szerint a nemzeti és regionális szintü kormányzati politikáknak jelentős hatása lehet a klaszterek kialakulására, fejlődésére. Többek között ezért is került be a klaszterek fejlesztése a tagállamok gazdaságfejlesztési és innovációs politikájába és a Közösség ezért támogatja a 
tagállamokat a klaszterek létrehozásában. A memorandumot több mint 70 nemzeti és regionális hatóság, ügynökség írta alá (HIGH LEVEL ADVISORY GROUP ON CLUSTERS 2007).

Az Európai Bizottság 2008 októberében adott ki közleményt a klaszterekre vonatkozóan "Úton a világszínvonalú klaszterek felé az Európai Unióban: A széles körü innovációs stratégia végrehajtása" címmel, amely egy koherens megközelítést tartalmaz a még több világszínvonalú klaszter kialakulásának elősegítésére. Ennek egyik eszközeként a közleményben már megjelenik az Európai Klaszterpolitikai Csoport (European Cluster Policy Group) létrehozása, mely a „klaszterekkel foglalkozó magas szintű tanácsadó csoport” helyébe lép (EURÓPAI KÖZÖSSÉGEK BIZOTTSÁGA 2008/A).

A Bizottság 2008-as határozata támogatja a tagállamokat a saját klaszterpolitikájuk fejlesztésében, sőt kifejezetten felkéri az országokat, hogy ültessék be a klaszterpolitikáikat a nemzeti reformprogramjuk versenyképességi pillérjébe. Ösztönzi a klaszterek közötti transznacionális együttmüködéseket és egy új kísérleti kezdeményezést indít a klaszterszervezetek kiválóságának mérésére (EURÓPAI KÖZÖSSÉGEK BIZOTTSÁGA 2008/B).

$\mathrm{Az}$ Európa 2020 Stratégia, mely az Európai Unió kutatás-fejlesztés és innovációs szakpolitika kereteit 2020-ig meghatározó növekedési és foglalkoztatási stratégiája, szintén hatékony eszköznek tekinti a klasztereket, mind a kkv-k üzleti környezetének javítása, mind az innovációs együttmüködések fokozása tekintetében. A stratégia két zázlószhajó kezdeményezése az „Innovatív Unió” és a „Iparpolitika a globalizáció korában” is célul tűzte ki a klaszterek fejlesztését (EUROPEAN COMMISSION 2010).

A klaszterek szoros kapcsolatban állnak az Európai Unió Intelligens Szakosodási Stratégiájával (Smart Specialisation Strategies, továbbiakban S3), mely a felülvizsgált Kohéziós Politikán belül az Unió innovációs és gazdaságfejlesztési politikáinak megújulásának és ötvözetének is tekinthető. A klaszterpolitikákhoz hasonlóan az S3 stratégia is a termelékenységre és az innovációra összpontosít, mint a versenyképesség kulcsfontosságú mozgatórugóira; a regionális beágyazódás elősegítése és a közelség előnyeinek kiaknázása mellett. Az intelligens szakosodás ugyanakkor nagyobb hangsúlyt fektet az egyes tudásterületek közötti tudásterjedésre, különös tekintettel a feltörekvő új piaci rések lehetőségeire és legfőbb célja a regionális gazdaságok átalakítása az egyedi, tudásalapú, új tevékenységi területeken. A klaszterek, mint a regionális innovációs ökoszisztéma potenciális elemei, sok régió számára az S3 fejlesztésének és végrehajtásának egyik kulcsfontosságú építőelemei közé tartoznak (OECD 2013, EUROPEAN COMMISSION 2013).

A Bizottság 2017. szeptemberében terjesztette elő az Európai Unió megújított iparpolitikával foglalkozó stratégiáját "Beruházás az intelligens, innovatív és fenntartható iparágakba" címmel annak érdekében, hogy segítse az európai iparágakat, hogy vezető szerepet töltsenek be az innováció, a digitalizáció és a szén-dioxid-mentesítés terén. Az iparpolitikai stratégiájában a Bizottság kiemelte, hogy lépéseket kíván tenni annak érdekében, hogy a klasztereket sokkal inkább az iparpolitika stratégiai eszközeként alkalmazzák. Hangsúlyozta továbbá, hogy az induló vállalkozásoknak és a dinamikus kkv-knak Európában olyan kedvező üzleti környezetre és innovációs ökoszisztémára van szükségük, amely segíti őket a szakképzett emberekkel, a technológiai központokkal és a támogató szervezetekkel való kapcsolatteremésben, a régión belüli és régiók között a tudás terjedésének felgyorsítása és a globális értékláncokba való bekapcsolódás érdekében (EUROPEAN COMISSION 2017/A).

Az Európa Jövőjéről szóló Fehér Könyvben felvázolt forgatókönyvek is az ipari együttmüködések megerősítését hangsúlyozták, például a csúcstechnológiai klaszterekkel folytatott további együttmüködés és az innovációra és kutatásra irányuló közös befektetések révén (EUROPEAN COMISSION 2017/B). 
Az alábbiakban azokat a legfontosabb klasztereket támogató intézményeket, szervezeteket, szövetségeket mutatom be, amelyek hozzájárulnak a klaszterpoltikákban megfogalmazott célok teljesüléséhez és a klaszterek közötti kooperációk erősítéséhez.

A klaszterekkel foglalkozó Magas Szintü Tanácsadó Csoport 2006-ban jött létre azzal a céllal, hogy európai szinten koordinálja a klaszterpolitikával kapcsolatos egyeztetéseket. A csoportnak kiemelt szerepe volt a 2008-ban elkészült Európai Klasztermemorandum kidolgozásában.

A Bizottság 2008. október 22.-ei határozata rendelkezett az Európai Klaszterpolitikai Csoport hivatalos felállításáról (2008/824/EK). A 20 fős csoport olyan politikai döntéshozókat, kutatóintézeteket- és felsőoktatási intézményeket, továbbá az üzleti szférát képviselő személyeket tömörít magában, akik releváns kompetenciákkal rendelkeznek a versenyképességi és innovációs területeken (EURÓPAI KÖZÖSSÉGEK BIZOTTSÁGA 2008/B).

A csoport 2009 tavaszán kezdte meg másfél éves megbízatását az alábbi legfontosabb célokkal és feladatokkal:

- A klaszterek létrejöttét támogató szakpolitikai eszközök megismertetése a Bizottsággal és a tagállamokkal

- A klaszterekkel kapcsolatos jó és rossz gyakorlatok bemutatása, jövőbeni kihívások, nemzetközi trendek elemzése.

- Ajánlások megfogalmazása a közösségi klaszterpolitika javítására vonatkozóan, valamint a klaszterpolitikák és eszközök közötti kapcsolódási pontok feltérképezése

- Kapcsolattartás a fontosabb klaszteres szereplökkel, szervezetekkel, köztük például az Európai Klaszterszövetséggel (DOBRONYI, T. et al. 2011).

Az Európai Klaszter Megfigyelőközpont (European Cluster Observatory) ${ }^{l}$ rendszeres elemzéseket, statisztikai információkat tesz közzé az európai klaszterekről és klaszterpolitikákról, mellyel célja, hogy támogassa a tagállamokat és a régiókat az intelligens specializációs és klaszter stratégiák kialakításában, amelyek segítenek a vállalatoknak új, globális szintű előnyöket kialakítani a feltörekvő iparágakban a klasztereken keresztül, és ezáltal erősítik a klaszterpolitikák szerepét az európai ipar fellendítésében és az Európa 2020 stratégia céljainak elérésében. Az Európai Klaszter Megfigyelöközpont eszköztára Európaszerte segíti a döntéshozókat a klaszterpolitikák kialakításában, illetve felülvizsgálatában.

Az Európai Klaszter Megfigyelőközpont többek között egy az egész EU-ra kiterjedő összehasonlító klaszter-feltérképezést nyújt a tagállamoknak, a gazdasági tevékenységek földrajzi koncentrációjának és teljesítményének ágazati és ágazatközi statisztikai elemzésével. Az úgynevezett Európai klaszterpanoráma keretében folyamatos frissített és bővített adatokat biztosítanak az európai klaszterek statisztikai szempontú értékeléséhez, feltérképezéséhez, beleértve a tíz feltörekvő iparág teljesítményét és a kulcsfontosságú versenyképességi mutatóinak korrelációs elemzését. A fentieken túl számos tevékenységet végez még a Megfigyelőközpont úgy, mint az európai klaszter-trendek, regionális ökoszisztémaeredménytábla, európai stresszteszt elkészítése. Modern klaszterpolitikai tanácsadói gyakorlatot mutat be kiválasztott demonstrációs régiókra vonatkozóan. Összefogja az európai klaszterpolitikai döntéshozókat és érdekelt feleket különböző európai klaszterkonferenciák segítségével a magas szintü klaszterpolitikai párbeszéd elérése érdekében (KETELS, C. SERGIY, P. 2016).

2006-ban a PRO INNO Europe kezdeményezés keretében a Versenyképességi és Innovációs Program (CIP) finanszírozásából az uniós szintü állandó politikai párbeszéd fenntartása

\footnotetext{
${ }^{1}$ http://ec.europa.eu/growth/smes/cluster/observatory/
} 
érdekében megalapításra került az Európai Klaszter Szövetség (European Cluster Alliance $)^{2}$, amely az egyes országok klaszterpolitikáinak és programjainak kidolgozásáért és irányításáért felelős nemzeti és regionális hatóságait magában tömörítő nyitott platform. A szövetség célja, hogy az érintett klaszterpolitikai döntéshozók és klaszterfinanszírozó ügynökségek megosszák egymással tapasztalataikat, egyesítsék erőforrásaikat a felmerülö problémák megoldásában és ezáltal csökkentsék a klaszter-kezdeményezések szétaprózottságát és segítsék a klasztertámogatási rendszerek összehangolását Európában.

A Bizottság 2009-ben hozta létre az Európai Klaszter Kiválósága Kezdeményezést (European Cluster Excellence Initiative) ${ }^{3}$ a PRO INNO Europe részeként az európai klaszterek irányításának minőségbiztosítása érdekében. A kezdeményezés a klaszterek kiválóságának megerősítését és egyre több világszínvonalú klaszter létrehozását hivatott támogatni az Európai Unióban (DOBRONYI, T. et al. 2011). A kezdeményezés keretében kidolgoztak egy klaszterminősítési módszertant és minősítési „címkét” a professzionális klasztermenedzsment fejlesztése érdekében. Olyan benchmarking módszertant fejlesztettek ki a klaszter szervezetek számára, amelyek javítják a belső irányítási folyamatot és a szolgáltatások nyújtásának hatékonyságát, továbbá egy ehhez kapcsolódó képzési anyagot is összeállítottak. A Klaszterelemzés Európai Titkársága és az Európai Klaszter Kiválósági Alapítvány biztosítja a képzéseket, a benchmarking módszer fejlesztését és a kiválósági minősítési folyamatokat. 2014-ig 35 országból 566 klaszterszervezet alkalmazta ezt a módszertant és kapta meg a klaszter kiválóság bronz címkéjét, valamint 42 szervezet nyerte el az arany minősítést.

Az Európai Klaszter Együttmúködési Platform (European Cluster Collaboration Platform) ${ }^{4}$ az Európai Bizottság támogatásával jött létre a COSME program keretén belül A platform a klaszterek közötti tapasztalatcserét, a partnerkapcsolatok felkutatását és kialakítását segíti különböző információkkal, adatbázisokkal, egyéb szolgáltatásokkal és nemzetközi klasztertalálkozók szervezésével. A megalakulása óta számos rendezvénnyel, konferenciával ösztönzi az európai klaszterek transznacionális és ágazatközi együttmüködéseit, valamint a feltörekvő iparágakat és az intelligens szakosodást érintő klaszterpartnerségeket a gazdasági növekedés és a versenyképesség fokozása jegyében. Az úgynevezett „matchmaking” találkozók például az európai és a harmadik országbeli klaszterek együttmüködéseit támogatják a kölcsönös érdeklődésre számot tartó stratégiai területeken.

A klaszterpartnerségek mozgósítására irányuló European Strategic Cluster Partnerships for smart specialisation investment (ESCP S3) kezdeményezést ${ }^{5}$ azzal a céllal indították, hogy megerősítsék az iparági részvételt és az európai dimenziót a nemzeti és regionális intelligens szakosodási stratégiák végrehajtásában. Az ESCP-S3 specifikus célja a vállalkozások, különösen a kkv-k együttmüködésének előmozdítása, valamint a klaszterek közös akcióinak és beruházási projektjeinek támogatása az intelligens szakosodás kiemelt területein. A program lehetővé teszi a klaszterekben müködő szakosodott vállalkozások és más innovációs szereplők számára a kiegészítő kompetenciákkal rendelkező partnerek megtalálását, a nemzeti, regionális és ágazati határokat átlépő értékláncok kialakítását, valamint a technológiai központokhoz való hozzáférést, különösen a kulcsfontosságú technológiák (KET) és a digitális innovációs hubok körében.

A 2007-2013-as programozási időszakban az Európai Unió számos programja támogatta a klaszterek fejlesztését, melyek folytatásai a Horizon 2020, a COSME és az Interreg Europe

\footnotetext{
${ }^{2}$ http://www.eca-tactics.eu/eca/about

${ }^{3} \mathrm{https} / / /$ ec.europa.eu/growth/industry/policy/cluster/excellence_en

${ }^{4}$ https://www.clustercollaboration.eu/

${ }^{5}$ https://ec.europa.eu/easme/en/cos-clustpartn-2017-3-02-european-strategic-cluster-partnerships-smartspecialisation-investments
} 
Programok a 2014-2020-as támogatási ciklusban is további forrásokat biztosítanak a már kialakult klaszter együttmüködések megerösítésére.

$\mathrm{Az}$ innovatív és feltörekvő iparágakban müködő klasztereket a $\mathrm{CIP}^{6}$ (Competitiveness and Innovation Framework Programme) program támogatta célzottan. A CIP folytatásaként COSME $^{7}$ (Competitiveness of Enterprises and Small and Medium-sized Enterprises) elnevezéssel az Európai Unió Vállalkozások és a KKV-k versenyképességét támogató programja $^{8} 2014-2020$ között mintegy 2,3 milliárd euró költségvetéssel négy területen segíti a kis-és középvállalkozások forrásszerzését, nemzetközi piacra jutását, versenyképességét és vállalkozói készségeinek fejlesztését. ${ }^{9}$ A Cluster Go International felhívása 2014-ben indult az európai stratégiai klaszterpartnerségek létrehozásának és fejlesztésének támogatására. A Clusters Excellence Programjának célja pedig a klasztermenedzsment megerösítése, a professzionális üzleti szolgáltatások nyújtása az európai kkv-k számára, annak érdekében, hogy minél több világszínvonalú klaszter alakuljon ki az Európai Unióban.

A klaszterek kutatás-fejlesztési és innovációs projektjei már az FP 6 (Sixth Framework Programme) és az FP 7 (Seventh Framework Programme for Research and Technological Development) programokon belül is támogatást nyerhettek. Jelenleg a Horizon 2020 az EU eddigi legnagyobb kutatási és innovációs programja támogatja az ipari és akadémiai szereplök közös kutatási együttmüködéseit. A Horizon 2020 INNOSUP ${ }^{10}$ kezdeményezése 2015 óta segíti a kkv-k innovációs potenciálján alapuló új, ágazatokon átívelő ipari értékláncok kialakítását az EU-ban, melyhez a klaszterek kedvező ökoszisztémát tudnak biztosítani és elvégzik a megfelelő koordinációs és motivációs tevékenységeket.

A kkv-k regionális és a határokon átnyúló együttmüködéseit az Európai Strukturális és Befektetési Alapok is támogatják. A nemzetközi klaszteres kezdeményezések jelentős forrásokra pályázhattak az INTERREG és INTERREG EUROPE programokból is. Az INTERREG vagy 2014-től Európai Területi Együttmüködés (ETE) ${ }^{11}$ Program keretében a tagállamok közös akciókra és tapasztalatcserére épülő határon átnyúló, transznacionális interregionális együttmüködéseket valósítanak meg. A speciális területeken müködő és tevékenykedő klaszterek további uniós programokból is kaphatnak finanszírozási forrásokat a tevékenységükre, úgy mint például a LIFE programból ami az Európai Unió környezetvédelmi, természetvédelmi, éghajlat-politikai projekteket támogató pénzügyi eszköze, vagy az Erasmus+ program az unió jelenleg futó oktatási, képzési, ifjúsági és sport programja.

\subsection{A klaszterek teljesítményének mérése}

A klaszterek teljesítményének vagy eredményességének mérése igen bonyolult és összetett folyamat, egyrészről mivel nincs egy egységes, átfogó értékelési modell, másrészről pedig a klaszterek igen sokfélék lehetnek és a teljesítményük is többféle szempontból értelmezhető, ezért annak mérésére az országok sokszor saját szempontrendszert dolgoztak ki (ANDERSSON, T. et al. 2004). Magyarországon az akkreditációs pályázat tekinthető ilyen jellegü értékelési rendszernek, melyet a következő magyarországi klaszterekről szóló fejezetben mutatok be részletesen. Az alábbiakban két olyan módszert kívánok röviden ismertetni, amelyet az

\footnotetext{
${ }^{6} \mathrm{http}: / /$ ec.europa.eu/cip/index_en.htm

${ }^{7} \mathrm{https}$ ://ec.europa.eu/growth/smes/cosme

${ }^{8} \mathrm{https} / / /$ ec.europa.eu/easme/en/cosme

${ }^{9}$ 1287/2013/EU rendelet a COSME program létrehozásáról

${ }^{10} \mathrm{http}$ ://ec.europa.eu/research/participants/portal/desktop/en/opportunities/h2020/topics/innosup-01-20162017.html

${ }^{11}$ https://ec.europa.eu/info/eu-regional-and-urban-development/cooperation-between-regions/europeanterritorial-cooperation-interreg_hu
} 
Európai Unió szintjén egységesen alkalmaznak a klaszterek értékelésére. Az első szempontrendszer az Európai Klaszter Obszervatórium átfogó értékelése kifejezetten a klaszter egészének teljesítményét kívánja megragadni, míg a második példa az Európai Klaszter Kiválósági Kezdeményezés inkább a klaszter vezetésének minőségét vizsgálja uniós szinten.

Az Európai Klaszter Obszervatórium az Európai Klaszterpanoráma keretében folyamatos (jellemzően két évente közzétett) frissített és bővített adatokat biztosít az európai klaszterek statisztikai térképezéséhez. A legutóbbi 2016-os elemzés a 2014-es Klaszterpanoráma elemzéshez képest jelentősen kibővített adatkészlettel dolgozik, ilyen például a cégszintü adatok bevezetése, mely újabb mutatók bevonását, új elemzések elvégzését teszi lehetővé (Ketels, C. - SerGiY, P. 2014). A figyelem középpontjában két új szempont került a klaszterprofilok heterogenitása és a klaszter-evolúció dinamikája. Az elemzés lehetővé teszi a klaszter- evolúció dinamikájának nyomon követését is, vagyis mennyi változás figyelhető meg idővel a klaszterek és feltörekvő iparágak gazdasági földrajzában, valamint a régiók gazdasági összetételében.

Ahogyan az alábbi 2. ábra is mutatja, a klaszterek erősségét egy összetett koncepcióval mérik, melyben szerepet kap a méret, a termelékenység és a dinamizmus mellett a specializáció is.

\section{2. ábra A klaszterek teljesítményének mérésére szolgáló mutatók}

\section{TELJESÍTMÉNY MUTATÓK}

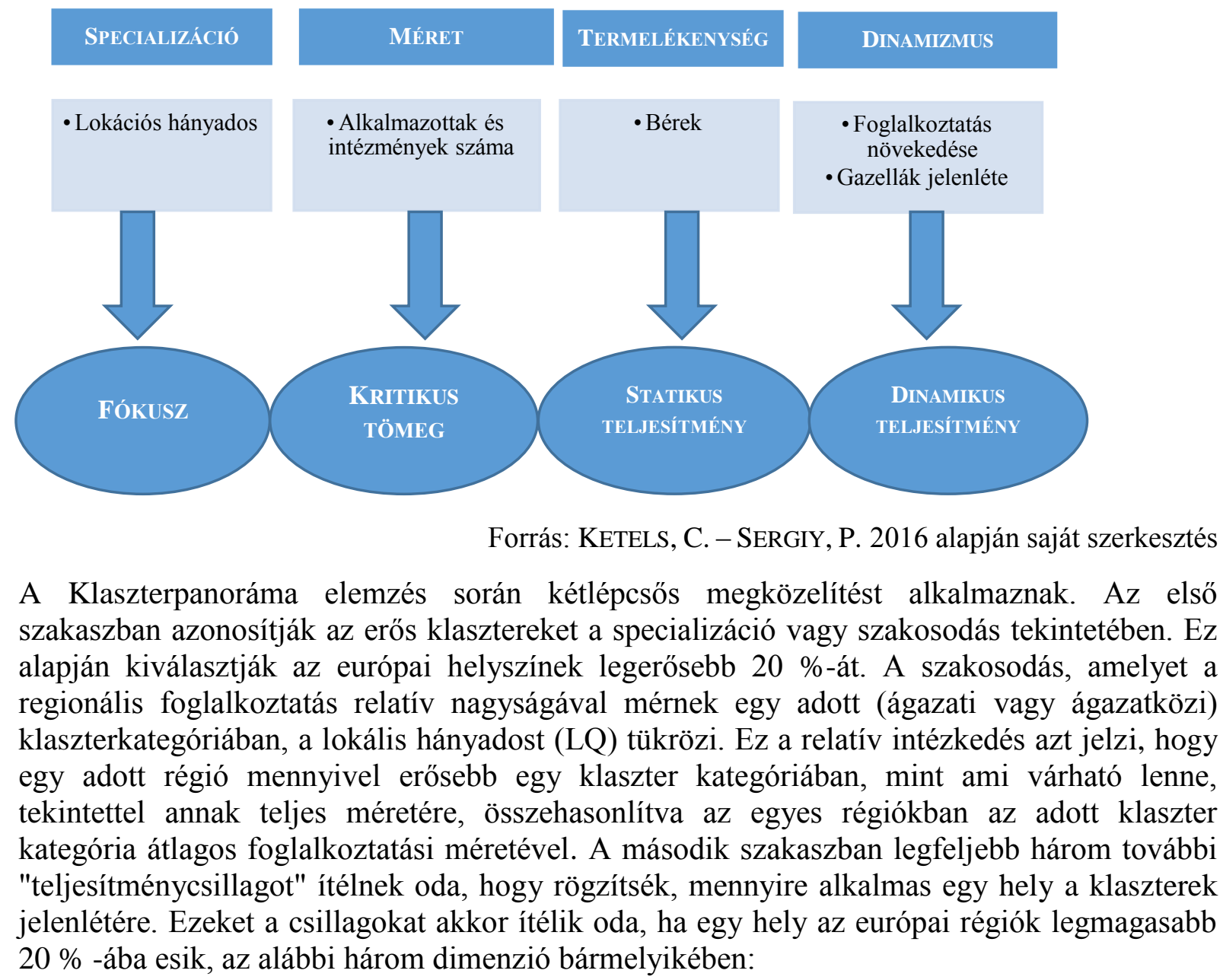


1. Abszolút méret, az alkalmazottak és a létesítmények számával mérve. Ez az intézkedés azon a megfigyelésen alapul, hogy a klaszteren belüli kapcsolatok száma exponenciálisan növekszik a résztvevők számával. Ha egy adott klaszter kategóriában a gazdasági aktivitás meghaladja a kritikus tömeg küszöbét, a klaszterhatások jelentősek lesznek.

2. Termelékenység, amelyet a regionális klaszterben fizetett bérek (a helyi költségszintekhez igazítva) segítségével mérnek. A béreket a munkaerőpiacok szerkezete és más tényezők is befolyásolnak ugyan, de erősen korrelálnak a termelékenységgel.

3. A dinamizmus, amelyet a foglalkoztatás növekedésével és a gyorsan növekvő új cégek (gazellák) jelenlétének egyszerű mértékével mérnek. Az intézkedés célja annak megragadása, hogy egy klaszter továbbra is kihasználja-e az erőteljes klaszterhatásokat a fejlődésében, vagy sem. A klasztert ugyanis gátolhatja a növekedés, mert már elérte azt a szintet, ahol a költségek nagyobbak, mint az előnyök vagy egyéb tényezők.

A két első foglalkoztatási mutató képezte alapját az első európai klaszter feltérképezés során alkalmazott "háromcsillagos" módszertannak, melyet az Európai Klaszter Obszervatórium dolgozott ki 2007-ben. A jelenleg alkalmazott legújabb mérési módszertan a 2014-es Klaszterpanoráma módszertanát követi, azzal, hogy mint új tényező kezeli a gyorsan növekvő új vállalkozásokat, úgynevezett gazellákat, a dinamizmus mérése során.

A teljesítmény mérésére szolgáló mutatókat megfelelő körültekintéssel kell kezelni, hiszen minden mutatónak van bizonyos ,gyengesége” pl. az abszolút foglalkoztatási méret az alacsony termelékenység jele is lehet, de összességében a négycsillagos klaszterek olyan kiemelkedő teljesítményt mutatnak, melyekre érdemes odafigyelni (KETELS, C. - SERGIY, P. 2016). Európában a klasztercsillagok tekintetében vannak olyan régiók, amelyek már több négy csillagos klaszterrel is rendelkeznek, úgy mint Stuttgart vagy Hamburg. Emellett számos olyan régió van, amely kiemelkedő számban ad otthont egy, két vagy háromcsillagos klasztereknek különböző iparágakban. Az alábbi 1. táblázat a vezető európai régiókat mutatja be a klasztercsillagok számát tekintve:

1. táblázat: Európa vezető régiói a klasztercsillagok tekintetében

\begin{tabular}{|c|c|c|c|c|c|c|}
\hline Régió neve & $\begin{array}{c}\text { Összes } \\
\text { csillag }\end{array}$ & $\begin{array}{c}\text { 1 csillagos } \\
\text { klaszterek }\end{array}$ & $\begin{array}{c}\text { 2 csillagos } \\
\text { klaszterek }\end{array}$ & $\begin{array}{c}\text { 3 csillagos } \\
\text { klaszterek }\end{array}$ & $\begin{array}{c}\text { 4 csillagos } \\
\text { klaszterek }\end{array}$ & $\begin{array}{c}\text { Az erôs } \\
\text { klaszterek } \\
\text { foglalkoztatási } \\
\text { aránya (\%) }\end{array}$ \\
\hline Isztambul & 101 & 3 & 31 & 12 & 0 & 58,14 \\
\hline Ober Bayern & 92 & 9 & 23 & 1 & 1 & 48,34 \\
\hline Île de France & 92 & 10 & 32 & 6 & 0 & 63,75 \\
\hline Stuttgart & 83 & 10 & 20 & 7 & 3 & 56,29 \\
\hline Lombardia & 80 & 17 & 19 & 7 & 1 & 63,65 \\
\hline Köln & 80 & 7 & 26 & 7 & 0 & 44,26 \\
\hline Darmstadt & 76 & 13 & 21 & 7 & 0 & 53,28 \\
\hline Hamburg & 73 & 13 & 14 & 8 & 2 & 67,49 \\
\hline Düsseldorf & 73 & 16 & 15 & 9 & 0 & 32,04 \\
\hline Slaskie & 72 & 15 & 25 & 1 & 1 & 61,61 \\
\hline Wielko-polskie & 72 & 13 & 25 & 3 & 0 & 56,89 \\
\hline
\end{tabular}

Forrás: KETELS, C. - SERGIY, P. 2016 alapján saját szerkesztés 
A klaszterek minősítésére vonatkozó másik uniós szinten elismert módszertan a 2009-ben létrejött Európai Klaszter Kiválósági Kezdeményezés (ECEI). Az ECEI fö célja ${ }^{12}$ az volt, hogy lehetőséget adjon a klaszterszervezetek számára, hogy értékelhessék a saját munkájukat és a szükséges területeken javítsák belső menedzsmentjüket, szolgáltatásaikat. Másrészről az ECEI képzési anyagokat és tematikát is nyújt a klasztervezetők számára, annak érdekében, hogy javítsák saját vezetői képességeiket. Az ECEI a különböző európai országok klaszterszakértői által kifejlesztett indikátorokat alkalmaz a „kiválósági státusz” értékeléséhez. A 31 mutatóból álló szempontrendszer átfogó értékelést ad a klaszter menedzsment szervezetről a szerkezet, a kormányzás, a pénzügyi alapok, a stratégia, a célok, a szolgáltatások és a megvalósítás szempontjait tekintve. Az értékelést végző klaszterelemző szakemberek nem csak a klasztermenedzsment szervezet kiválósági állapotát értékelhetik, hanem segíthetnek a javításra szoruló területek meghatározásában és a klaszter menedzserek fejlesztésében. Az ECEI által elfogadott szabványok szerinti minőségi címkézés támogathatja a klasztervezetőket az új és jobb klaszterszolgáltatások fejlesztésében, és jobb finanszírozási lehetőségek és klaszterszervezési stratégiák létrehozásában. A címke nemcsak ösztönzőleg hat a klasztermenedzserek tevékenységére a fejlődés érdekében, de a politikai döntéshozóknak, programalkotóknak is segítséget és támpontot nyújt a kiváló klaszterek azonosításában (Christensen, T. et al. 2012).

A minősítési módszertan elsősorban a klasztermenedzsment tevékenységére irányul, mégis számos indikátor esetén megjelennek olyan feltételek, amelyek a klaszter egészére (pl. összetétel, méret, koncentráció, finanszírozás stb. ) vonatkoznak.

A minősítés során alkalmazott legfőbb indikátorcsoportok a következőek:

- Klaszter összetétele

- Klaszterirányítás, vezetés, együttmüködés

- Finanszírozás

- Stratégia

- Eredményesség és elismertség

A minősítés 3 fokozatból bronz, ezüst és arany címkéből áll. A klaszterek az első alkalommal 2 évre vonatkozóan bronz minősítést szerezhetnek, melyet a 2 év után vagy elvesztenek, vagy az újabb értékelési körben a fejlődés tekintetében ezüst vagy arany minősítést kaphatnak. Az ECEI eddig 35 ország 600 klaszterszervezetét minősítette, melyből 42 szerezte meg az arany címkét (COLOSSEUM BUDAPEST KFT. 2015).

\subsection{A klaszterprogramok átalakulása, új fókuszpontok kialakulása}

Az elmúlt tíz évben egyre több elemzés irányult a klaszterek összetételében, méretében, menedzsment struktúrájában rejlő különbségekre és a sikerességük legfontosabb kulcstényezőire (LÄMMER-GAMP, T. et al. 2011, KETELS, C. et al. 2013). A klaszterprogramok indulásakor inkább a pénzügyi támogatás volt a jellemző támogatási eszköz, a nem pénzügyi jellegü ösztönzőkkel szemben, bár az anyagi jellegü segítségnyújtás önmagában nem bizonyult teljesen hatékonynak, arra vonatkozóan, hogy hosszútávon fenntartható és önmüködő klaszterszervezetek alakuljanak ki. A menedzsment szervezetek fejlesztésére

12 http://www.clusterexcellence.org/background/\#blockyui_3_17_2_60_1488397578257_4432 http://www.clusterpolisees3.eu/ClusterpoliSEEPortal/resources/cms/documents/2012.05.22_The_quality_label_a nd_indicators_for_cluster_organisations_assessment.pdf 
irányuló technikai segítségnyújtás, úgy mint képzés vagy coaching biztosítása 2012-ben még csak a programok felében került alkalmazásra, míg három évvel később már a nemzeti és regionális programok kétharmadában megjelentek az ilyen jellegü támogatási elemek (MÜller, L. et al. 2012, MEIER ZU KÖCKER, G. - MÜLLER, L. 2015).

A klaszterprogramok fejlödésével egyre több ország építette be szervesen a klaszterek támogatását az egyes szakpolitikáiba, így a klaszterprogramok ma már jól láthatóan kapcsolódnak a nemzeti vagy regionális szakosodási és innovációs stratégiákhoz. A legtöbb klaszterfejlesztési tevékenység a már létrejött és müködő klaszterek fejlesztésére és nemzetközi szinten történő megerösítésére irányul és már kevésbé cél új, induló klaszterek ösztönzése. A legfontosabb gazdasági szektorokban már létrejöttek a meghatározó szereplöket magukban tömörítő klaszterek és a fókusz egyre inkább a különböző iparágakban müködő klaszterek közötti interszektoriális együttmüködésére helyeződik át. (LÄMMER-GAMP, T.et al. 2014). A klaszterszervezeteket egyre több programban támogatják olyan specifikus üzleti szolgáltatások kialakítására, amelyek segítik a vállalkozásokat, hogy hatékonyan tudjanak szembenézni a növekvő piaci és technikai kihívásokkal, be tudjanak kapcsolódni a feltörekvő iparágakba és az ágazatközi együttmüködésekbe (CHRISTENSEN, T. et al. 2012, KERGEL, H.et al. 2014, MEIER ZU KÖCKER, G. - MÜLLER, L. 2015).

A klaszterprogramok jelenlegi céljai között a nemzetköziesedés is igen elökelö helyen szerepel és a legtöbb program célzott támogatásokkal segíti a klaszterek nemzetközi kapcsolatainak kiépítését és nemzetközi piacokon való megjelenését. A klasztermenedzsment szervezet felkészültségének és kiválóságának támogatása is sokkal inkább elötérbe került a European Cluster Excellence program minősítési rendszere által.

Az Európai Klaszter Megfigyelöközpont 2015-ben elkészült elemzése alapján tehát a klaszterprogramokban bekövetkezett legföbb változásokat és új irányokat az alábbiakban lehet összefoglalni (MEIER ZU KöCKER, G. - MÜLlER, L. 2015):

- Kevesebb dedikált forrás áll rendelkezésre a klaszterek támogatására, mivel a klasztereknek egyre inkább a regionális fejlesztési és innovációs politikák megvalósításában van szerepe és kevésbé cél már önmagában a klasztereket támogatni. Ennek a trendnek köszönhetően egyre több regionális együttmüködési forma van kialakulóban.

- Sokkal nagyobb hangsúly helyeződik a fejlett, világszínvonalú klaszterek támogatására, mint az újak létrehozására.

- Az iparági és ágazatközi együttmüködések támogatása mellett fókuszba kerültek a feltörekvő iparágakban müködő klaszterek.

- A klasztermenedzsment kiválóságának támogatása szinte minden programban megtalálható és nagyobb jelentőséget kapott az elmúlt időszakban.

- A klaszterek nemzetközivé válása továbbra is fontos eleme a programoknak és egyre több intézkedés segíti elő az ezt támogató tevékenységeket.

- Sok program elkülönült költségvetéssel rendelkezik a klasztermenedzsment szervezetek speciális támogatására irányulóan a nemzetköziesedés, klaszterközi együttmüködések, klaszter menedzsment kiválósága területeken.

- Egyre inkább elötérbe kerülnek a nem pénzügyi jellegü ösztönzők a pénzügyi támogatásokkal szemben. A nemzeti és regionális programok $75 \%$-a tartalmaz speciális technikai segítségnyújtási és tanácsadási elemeket. A spanyol "Pro-grama Catalunya Clusters" és a német "go-cluster" program például már egyre inkább az ilyen jellegü támogatásokra épül.

- A programok nagy része illeszkedik és szervesen kapcsolódik a nemzeti és regionális specializációs és innovációs stratégiákhoz.

Az európai klaszterprogramok 2016-ban készült összehasonlító értékelése is a klaszterprogramok fentiekhez hasonló jellegü változásaira mutatott rá a tervezés, a stratégiák 
és az eszközök tekintetében. A programok közös jellemzője, hogy már a kezdetektől fogva a nemzeti vagy regionális gazdaság versenyképességének növelésére összpontosítanak, de az utóbbi években a nemzeti klaszterprogramok egyre inkább a feltörekvő iparágak fejlődése és az érett klaszterek támogatása irányába mozdultak el. A legfontosabb változás, hogy az egyes programok sokkal fókuszáltabbá váltak és a meglévő érett klaszterszervezetek továbbfejlesztésére koncentrálnak, így csak korlátozott számú intézkedés támogatja az induló klaszterszervezeteket. A finanszírozás szempontjából még mindig nagy különbségek vannak az egyes országok programjai között, de egyre több esetben szerepet kap az úgynevezett technikai segítségnyújtás a klaszter-szervezetek képzése és coaching-ja érdekében A klaszterfejlesztések erősségeinek és gyengeségeinek elemzésével az intelligens klaszterpolitikai útmutató az alábbi ajánlásokat fogalmazta meg a klaszterpolitikák döntéshozói számára (IZSAK, K. et al. 2016):

- Egyedi szakosodott cégek támogatása helyett, a csoportok vagy hálózatok új tevékenységeinek támogatása a kapcsolódó iparágakban.

- Olyan stratégiai klaszter kezdeményezések támogatása, amelyek középpontjában az erősségek, kapcsolatok és az újszerü kompetenciák támogatása áll, és amelyek összhangban vannak a nemzeti / regionális intelligens szakosodási stratégiák céljaival.

- A regionális kompetenciák kiaknázása az új tevékenységi területek és feltörekvő iparágak támogatása érdekében.

- A szűk ágazati klaszterkoncepciók helyett a szektorokon átívelő szisztematikus megközelítések támogatása.

- A klaszterpolitika elszigeteltsége helyett, más szakpolitikai területek $(\mathrm{K}+\mathrm{F}$, innováció, vállalkozásfejlesztés, nemzetközi kapcsolatok) és a szereplők széles körének bevonása (vállalkozások, befektetők, akadémiai szereplők, politikai döntéshozók) a klaszterprogramok tervezése és felülvizsgálata során.

- Olyan regionális partnerségek támogatása, amelyek be tudnak kapcsolódni a nemzetközi értékláncokba, és amelyek csatlakozni tudnak az európai stratégiai klaszterpartnerségekhez.

\subsection{A klasztermenedzsment szervezetek szerepe és kihívásai}

A klaszterfejlesztési politikákban bekövetkezett változások egyre inkább a klasztermenedzsment szervezetek szerepére és jelentőségére terelik a hangsúlyt. A klaszterek indulásakor a fő cél nyilvánvalóan a megfelelő szervezeti keretek és stratégia dokumentumok, közös fejlesztési irányok és alapvető adminisztrációs szolgáltatások biztosítása volt a menedzsment szervezetek részéről. A klaszterek fejlödésével együtt azonban egyre inkább beigazolódott, hogy a klasztermenedzsmentnek sokkal nagyobb szerepe van a klaszterek sikerességében, mintsem csak az adminisztrációs háttér és információ megosztás kereteinek biztosítása (KETELS, C. et al 2013). Bár a klaszterek sikerének alapját a klasztertagok lehetőségei és a támogató keretfeltételek adják, a klaszter menedzsment szervezetek hozzájárulnak a klaszter résztvevői és a külső szereplők közötti együttmüködések kialakulásához, továbbá hatékonyabban tudják közvetíteni a klasztertagok igényeit az egyes politikai döntéshozók irányába (BuHL, C. M. - KöCKER, G. M. 2009). A menedzsment szervezet kapcsolatteremtési képességének is nagy szerepe van a klaszter sikerében, versenyképességében, innovációs teljesítményében, hiszen a menedzsment szinte napi kapcsolatban áll az egyes tagokkal, a klaszterhez kapcsolódó külső szereplőkkel, más klaszterekkel, finanszírozási intézményekkel. Ezen kapcsolatok gyakorisága és minősége pozitívan hat és a klaszter teljesítményére (KETELS, C. et al 2013).

A klasztermenedzsment szervezetek körében 2013-ban végzett felmérések alapján azonban látható, hogy a klasztermendzsment szervezetek nagyon sokat fejlődtek a 2000-es évek 
elejéhez képest. Sokkal formalizáltabban lettek, tapasztalt klasztermendzser áll az élükön, rendszeres elemzéseknek vetik alá magukat, számos szolgáltatást és tevékenységet végeznek a klaszter érdekében, melyek 3 pillér mentén foglalhatóak össze. Az elsö pillér a hálózatszervezési feladatok mellett, a kölcsönös bizalom és klaszter identitás, közös klasztertudat felépítéséről szól. A második pillér a kutatás-fejlesztési és innovációs tevékenységek ösztönzéséhez kapcsolódik, ahol a klaszterszervezetek segíthetnek az innovációs szakadékok áthidalásában, a tudásáramlás előtti akadályok megszüntetésében, egyfajta inkubátorként szolgálhatnak és hatékonyan müködnek közre a létrehozott kutatásfejlesztési eredmények piacosításában. A harmadik pillér pedig magában foglalja a tagvállalatok körében végzett üzletfejlesztési feladatokat, közös beszerzéseket, közös exportpiaci megjelenéseket és a nemzetközivé válás érdekében tett lépéseket (KETELS, C. et al 2013). A klaszterszervezetek fenti három pillér mentén nyújtott szolgáltatásai kulcsfontosságú eszközei a klaszteres együttmüködések ösztönzésének és a szolgáltatások köre és színvonala egyértelmü hatással van a klasztertagok üzleti, kutatás-fejlesztési és nemzetközi tevékenységére (CHRISTENSEN, T. et al. 2012, KETELS, C. et al. 2012). A klaszter szolgáltatások hatásaira irányuló vizsgálatok bebizonyították, hogy önmagában az egyes szolgáltatások magas intenzitása nem képes támogatni a klaszter eredményességének növekedését. A szolgáltatások mennyisége mellett nagy hangsúly van a szolgáltatásnyújtás minőségén is. A klasztertagok számára nyújtott speciális szolgáltatások megfelelö kombinációja azonban jó hatással lehet a klaszterben müködő szervezetek, vállalkozások üzleti és $\mathrm{K}+\mathrm{F}$ teljesítményére és ezáltal a klaszter megítélésére, sikerességére. A klaszterfejlesztési politikáknak és programoknak ezért minél inkább támogatniuk javasolt a klasztermenedzsment szolgáltatási portfóliójának fejlesztését, nem csak pénzügyi forrásokkal, de olyan technikai jellegü segítségnyújtással is, mint a képzések, workshopok, tapasztalatcsere és a jó gyakorlatok megismerésének biztosítása. A klaszterek szolgáltatási portfóliója nagyban függ a klasztermenedzserek kompetenciáitól, szakértelmétől és attól, hogy a menedzsment mennyire képes megismerni a klaszter résztvevőinek igényeit és szükségleteit (NERGER, M. et al. 2014).

A klaszterszervezeteknek a klaszterek tevékenységeinek és céljainak fejlődésével az alábbi kihívásokkal kell szembenézniük a tevékenységük során (NERGER, M. et al. 2014, KERGEL, H. et al. 2014):

- A menedzsmentnek egyre komplexebb szolgáltatásokat kell nyújtania, melyek hozzájárulnak a klaszterben résztvevő vállalatok, kutatóintézetek, egyetemek és más intézmények közötti tudásátadáshoz és együttmüködéshez.

- Szorosan nyomon kell követniük a legújabb technológia és az üzleti trendeket az adott klaszter szempontjából releváns ágazatokban. A trend-monitorozás támogatja a klaszter új lehetőségeinek azonosítását.

- A klaszter tevékenységét nem csak egy szük ágazati fókuszban, hanem a kapcsolódó iparágak és kompetenciák ökoszisztémájaként kell értelmezniük.

- A klaszter tagjait be kell vonni a szolgáltatások fejlesztésébe és a folyamatos kommunikáció, rendszeres találkozók segítségével nyomon kell követni a résztvevők igényeinek változását.

- A nemzetközi trendeknek megfelelően a klasztermenedzsereknek speciális szolgáltatásokat kell kialakítaniuk az ágazatközi együttmüködések elöremozdítása érdekben. Azonosítani kell a más iparágakban elérhetö lehetőségeket, majd meg kell találni a megfelelő partnereket és végül a projektfejlesztési és tudástranszfer szolgáltatások segítségével meg kell találniuk a megvalósítás leghatékonyabb módját.

- A klasztermenedzsment felkészültsége, szaktudása és tapasztalata elengedhetetlen feltétele a sikernek, hiszen nem titkári pozíciót töltenek be, sokkal inkább olyan 
tanácsadói szerepben kell, hogy müködjenek, akik figyelemmel kísérik az üzleti és iparági trendeket, konstruktív módon készítik elő a stratégiai döntéseket és hatékonyan mozgósítják a klaszterben meglévő erőforrásokat.

A fentiek alapján a klasztermenedzsment szolgáltatásainak körét, azok hatásait és a kapcsolódó kihívásokat az alábbi 3. ábra foglalja össze.

\section{3. ábra A klasztermenedzsment legfőbb szolgáltatásai és azok hatásai}

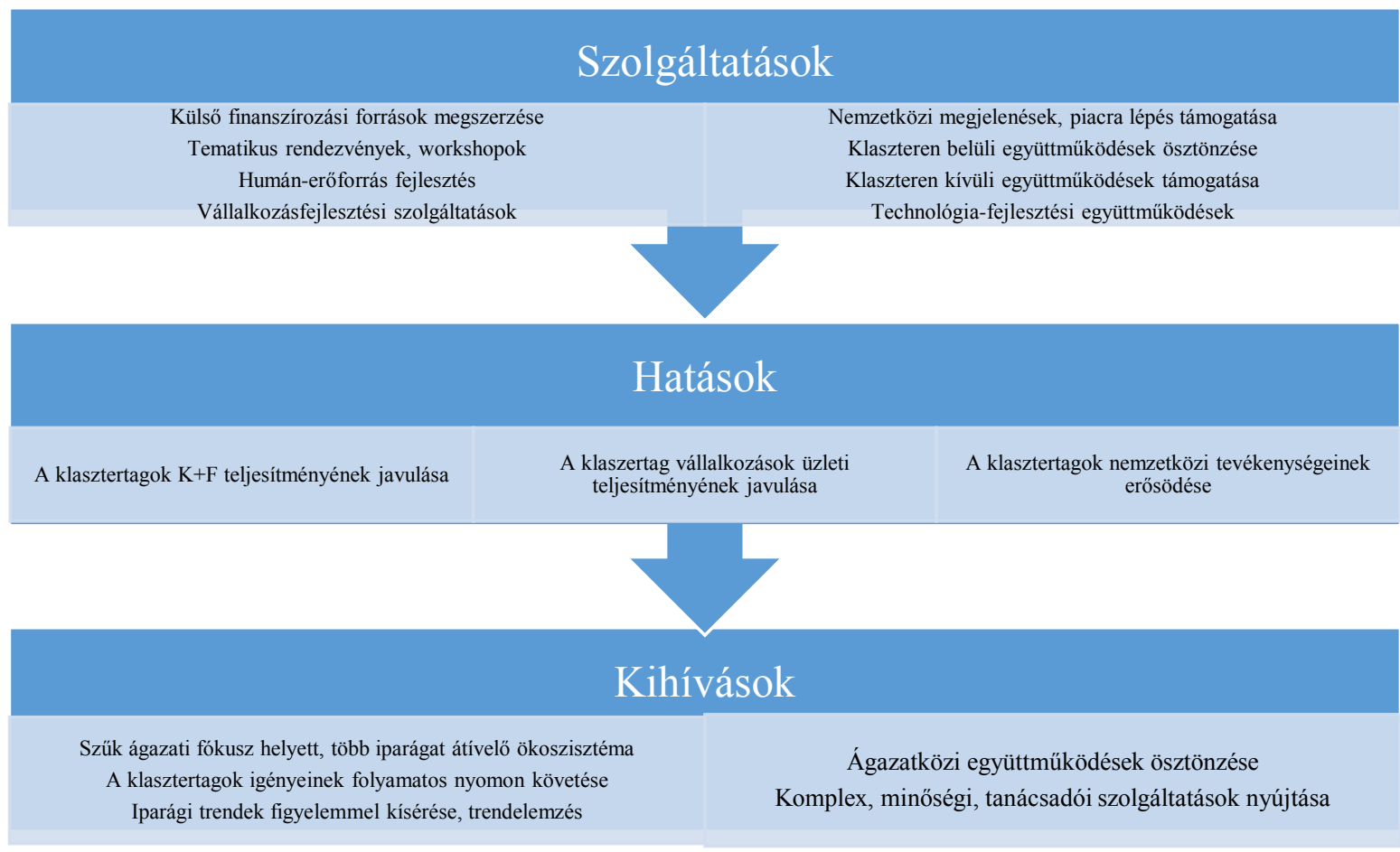

Forrás: CHRISTENSEN, T. et al. 2012, NERGER, M. et al. 2014 alapján saját szerkesztés

A 3. fejezet alapján látható, hogy a 2000-es évek eleje óta egyre átfogóbb és tudatosabb klaszterfejlesztési politika támogatja a klaszterek létrejöttét, fejlődését mind uniós mind tagországi szinten. Különböző szervezetek, intézmények, együttmüködési formák jöttek létre a klaszterek ösztönzésére. Több uniós programban megjelentek a klaszterek, mint a vállalkozói versenyképesség és innováció ösztönzésének lehetséges eszközei és ennek megfelelően egyre több pénzügyi forrás állt rendelkezésre azok fejlesztésére. A 2010-es évek elejétől kezdve a figyelem már sokkal inkább a klaszter kezdeményezések teljesítményének mérésére irányult, melyre vonatkozóan többféle módszer is kidolgozásra került nemzeti és uniós szinten egyaránt. A különböző klaszterfejlesztési programok fókuszpontjai is fokozatosan átalakultak az elmúlt években és egyre inkább a különbözö iparágakban müködö klaszterek közötti interszektoriális együttmüködések ösztönzésére és a klaszterek nem pénzügyi jellegü támogatására helyeződtek át, melyben nagy szerepe van a klasztermenedzsment szervezetek szaktudásának, tapasztalatának és erőforrásainak. 


\section{KLASZTEREK MAGYARORSZÁGON ÉS A DÉL-ALFÖLDI RÉGIÓBAN}

\subsection{Klasztertámogatási rendszer Magyarországon 2000 és 2013 között}

Magyarországon az első klaszterek a 2000-es évek elején alakultak meg az ország fejlett régióiban, jellemzően az autóiparhoz kapcsolódóan. A klaszterek kialakulását elösegítő klasztertámogatási rendszer előzményeként az 1990-es évek második felében jelentek meg olyan beszállítói programok, amelyek célja kifejezetten a vállalkozások és egyéb piaci szereplők közötti együttmüködés megteremtése és a cégek közötti beszállítói kapcsolatok fejlesztése volt. Ezt követően az I. Széchenyi Terv Regionális Gazdaságépítő Programja nyújtott célzott támogatást a klaszterkezdeményezések számára, a szervezeti rendszer és a kapcsolódó információs rendszer alapjainak kialakításához. A támogatás a klasztermenedzsment szervezet felállításához és a menedzsment által nyújtott különböző szolgáltatások (partnerkeresés, üzletember találkozók, képzések lebonyolítása) megteremtéséhez nyújtott 50\%-os támogatási intenzitású vissza nem térítendő forrást. Az első klaszteres támogatások hatására 10 klaszter jött létre különböző iparágakban úgy, mint az autóipar, fa- és bútoripar, építöipar, élelmiszeripar és textilipar (SZÉCHENYI TERV 2000). A következő lépcsőfokot az I. Nemzeti Fejlesztési Terv Gazdaság és Versenyképesség Operatív Programja jelentette 2004 és 2006 között, melynek több intézkedése is támogatta közvetlen vagy közvetett módon a vállalkozások közötti együttmüködések, hálózatok, klaszterek kialakulását (I. NEMZETI FEJLESZTÉSI TERV 2004-2006). A 2006-os év végéig alig néhány tucat klaszteres együttmüködés alakult ki és csak nagyon kevés működött valójában klaszterként. Ezek közül a legerősebbek és legismertebbek például az autóiparhoz kötődő Pannon Autóipari Klaszter, a Pannon Elektronikai Klaszter, továbbá Pannon Fa- és Bútoripari Klaszter. A Dél-alföldön textilipari, kézmüves, útépítési és turisztikai klaszter jött létre, melyek közül hosszabb távon a textiliparban és a turizmusban létrejött együttmüködések bizonyultak tartósnak.

A 2007-2013-as időszak fejlesztési programja, az Új Magyarország Fejlesztési Terv már kiemelt hangsúllyal kezelte a klaszterfejlesztést, mivel a program kidolgozói úgy vélték a sikeres nemzetközi példák alapján a klaszterek segítségével komoly gazdaságfejlesztési potenciál érhető el, ezért szükséges azok létrehozásának és megerősítésének felülről vezérelt ösztönzése. A Kormány által 2008-ban jóváhagyott Pólus Program a pólusvárosok fejlesztése mellett a gazdaságfejlesztési koncepció másik fontos pillérének tekintette a magas hozzáadott értékü, exportorientált, innovatív klaszterek támogatását. A Pólus Program és a később továbbfejlesztett Klaszterfejlesztési Program, egy többszintű komplex klaszterfejlesztési koncepciót fogalmazott meg, amelyben különböző típusú forrásokkal és tevékenységekkel kívánták támogatni a klaszterek fejlődésének egyes fázisait (PóLUS PROGRAM 2008).

A 2007-2013-as programozási időszakra vonatkozó, eredetileg 4 szintüre tervezett, de 3 szinten megvalósult klaszterfejlesztési modell a 4. ábrán láthatóan több lépcsőben és különböző eszközökkel ösztönözte a klaszterek kialakulását és megerősödését. A Regionális Operatív Programokból nagy számban támogatták a megalakulásuk előtt, illetve a fejlődési pályájuk elején járó klasztereket, majd a stabil, hosszú távú és nagy gazdasági potenciállal rendelkező együttmüködések pedig a Gazdaságfejlesztési Operatív Program forrásaiból részesültek. 


\section{4. ábra Klaszterfejlesztési modell Magyarországon 2007-2013}

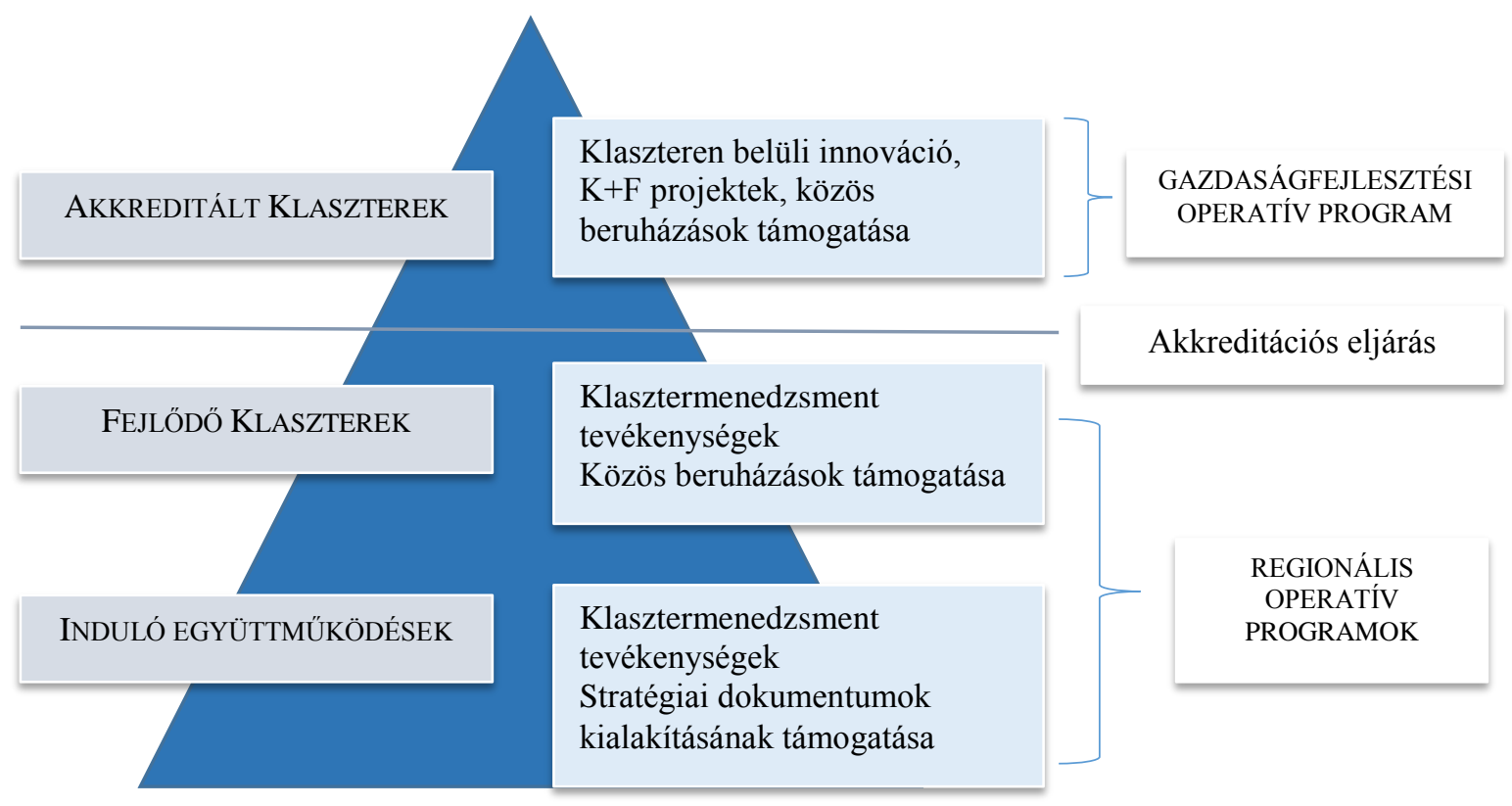

Forrás: Saját szerkesztés

Az induló klaszterekre vonatkozó regionális pályázatok célja a megfelelő számú és a régió szempontjából fontos iparágakat képviselö klaszterek kialakulásának támogatása és a tagok közötti kapcsolat és együttmüködés megerősítése volt. A Regionális Operatív Programok Klaszter menedzsment szervezetek létrehozására, megerősitésére irányuló pályázata regionális szinten támogatta a klaszterek fejlődésének első fázisát, az induló klaszterek létrehozását, a klaszterstratégia és szervezeti keretek kidolgozását és a klasztermenedzsment tevékenységek kialakítását. Célja volt, hogy elöremozdítsa a helyi vállalkozások, gazdasági szereplők, oktatási és kutatási intézmények klaszteres formában történő együttműködését és az induló kezdeményezések szervezeti és infrastrukturális hátterének megerősítését, valamint felkészítését a későbbi akkreditációs eljárásra. A tevékenységek között ennek megfelelően az új tagok felkutatását, az adminisztrációs háttér felállítását, különböző stratégiák, marketing és szervezetfejlesztési tanulmányok elkészítését, közös rendezvények, találkozók benchmarking klubok szervezését és projektgenerálást támogattak magas támogatási intenzitással. Ezt követte a klaszterfejlesztés második lépcsöje a Vállalati együttmüködés és klaszterek támogatása c. konstrukció mely még szintén regionális forrásokból, de már inkább a fejlődő klaszterek konzorciumaira és menedzsment szervezeteire irányult. A klasztermenedzsment alaptevékenységeinek támogatásán túl, a klaszterek nem $\mathrm{K}+\mathrm{F}$ jellegü közös projektjeire, beruházásaira és eszközbeszerzéseire fókuszált, az első fázisnál valamennyivel alacsonyabb támogatási intenzitás mellett (ÚJ MAGYARORSZÁG FEJLESZTÉSI TERV, 2007).

Ezt követően a klaszterfejlesztés 3. lépéseként egy központi minősítési eljárás, úgynevezett akkreditációs eljárás következett. Ennek célja, azoknak a klasztereknek a kiválasztása, amelyek magas innovációs és export teljesítményük, jelentős foglalkoztatási hatásuk és a hatékony együttmüködési tevékenységük révén jelentős fejlesztési projekteket képesek megvalósítani és nemzetközi szinten is komoly piaci potenciállal rendelkeznek. Az Akkreditált Innovációs Klaszter (AIK) címpályázat elnyerése ugyan nem járt közvetlen támogatással, de sikeres akkreditáció esetén a klaszterek és tagjaik jogosultságot nyertek el 
bizonyos pályázatokon való kizárólagos indulásra, illetve más konstrukciók esetén a kiírásban rögzített feltételek szerinti előnyre, többletpontokra tettek szert a kiválasztás során. Az akkreditációs címet pályázat útján két évre kaphatták meg a klaszterek és két év után meg kellett újítaniuk azt. Az akkreditációs cím elnyerésére irányuló pályázatban a klaszteren belül megvalósult együttmüködések, a klaszter összetétele, a klasztertag kkv-k gazdasági teljesítménye, a klaszter $\mathrm{K}+\mathrm{F}+\mathrm{I}$ teljesítménye, a klaszter stratégiája és cselekvési terve alapján értékelték az együttmüködéseket. Az akkreditációs eljárás hazai szinten komoly presztízst jelentett a címet elnyert klaszterek számára. A döntéshozók szempontjából pedig egyfajta biztosíték és kockázatcsökkentő tényezővé vált arra vonatkozóan, hogy a címet birtokló klaszterek valóban számos vállalkozást, felsőoktatási vagy kutatóintézetet és egyéb szervezetet képviselnek és az erős gazdasági és tudományos háttér biztosításával, nagy értékü és jelentőségű beruházásokat és kutatás-fejlesztési projekteket képesek megvalósítani. A hazai klaszterakkreditáció egy nagyon komplex példaértékü minősítési rendszer, azonban ennek is vannak bizonyos korlátai. Elsősorban az, hogy ez egy nemzeti szinten megalkotott és erre a szintre szóló minősítési rendszer, amelyet nagyon nehéz nemzetközi szinten elismertetni. Sajnos jelenleg még az Európai Unióban is csak néhány olyan minősítési eljárás van, amelyek széles körben elfogadottak. Az akkreditáció másik korlátját pedig abban látom, melyet a személyes interjúk is visszaigazoltak, hogy nagyon „kötött” szempontrendszerrel dolgozik, ami egyrészről persze nagyon fontos, hiszen biztosítja a rendszer objektivitását és ellenőrizhetőségét, másrészről vannak olyan speciális esetek, amelyeknél például erős, stabil háttérrel rendelkező klaszterek a szempontrendszer rugalmatlansága miatt „kizáródhatnak” az akkreditáció lehetőségéből.

A klaszterfejlesztés 3. szintjenként a Gazdaságfejlesztési Operatív Program (GOP) hatáskörébe tartozott az akkreditált, nemzetközi jelentőségü, magas foglalkoztatási és innovációs hatással rendelkező klaszterek közös kutatás-fejlesztési és innovációs projektjeinek támogatása.

Több olyan támogatási konstrukció is megjelent a programozási időszakban, amely kizárólag csak a klaszterek és tagjaik számára voltak elérhetőek. Ilyen dedikált források voltak például,

- a GOP-2011-1.2.1 - Akkreditált innovációs klaszterek közös technológiai innovációjának támogatása ${ }^{13} \mathrm{c}$. illetve,

- a GOP-2011-1.3.1/B - Vállalatok komplex technológiai innovációjának támogatása ${ }^{14}$ c. pályázatok, valamint ezek Közép-magyarországi régióra vonatkozó tükörpályázatai (KMOP -1.1.3/A és KMOP-1.1.3/C).

Ezeken felül a Gazdaságfejlesztési Operatív Program 1., 2., és 3. prioritásának pályázatai, továbbá a Közép-magyarországi Operatív Program (KMOP) 1. és 2. intézkedései keretében nyerhettek el támogatási forrásokat az Akkreditált Klaszterek tagvállalatai.

\subsection{A klaszterek jelenlegi támogatása}

A 2014-2020-as támogatási időszakban a klaszterek további támogatásának a Gazdaságfejlesztési és Innovációs Operatív Program (GINOP) ad keretet. Mivel az előző időszakban kellően nagy számban jöttek létre klaszterek az ország szinte minden területén és iparágában a megfelelő tudáscentrumok és ipari kapacitások mentén, így ebben a periódusban már nem kerül sor további induló klaszterek támogatására. A fejlesztési tevékenységek célja továbbra is a meglévő klaszterek közös tevékenységeinek és teljesítményének erősítése és ezáltal a nemzetközi szinten is látható együttmüködések előremozdítása.

\footnotetext{
${ }^{13}$ https://www.palyazat.gov.hu/doc/2916

${ }^{14}$ https://www.palyazat.gov.hu/doc/2693
} 
Az operatív program a megfelelő működési múlttal és/vagy Akkreditált Innovációs Klaszter címmel rendelkező klaszterekre kíván fókuszálni. A klaszterek támogatásának célja a klaszter menedzsment szervezetek szervezeti kereteinek javítása, továbbá a klasztertagoknak nyújtott szolgáltatások bővítése színvonalának emelése. Kiemelt cél továbbá az Akkreditált Innovációs Klaszterek és tagvállalatainak segítése az új nemzetközi piacokra történő eredményes belépés érdekében, továbbá az ezt ösztönző, nagyvállalatok és kkv-k együttműködésében megvalósuló beruházások, projektek támogatása (Gazdaságfejlesztési és Innovációs Operatív Program 2014).

A mára már egyfajta klaszteres policy-vá és nemzetközi szinten is kiemelkedő gyakorlattá vált akkreditációs eljárást 2008 óta többször felülvizsgálták, módosították, hangsúlyeltolódások voltak megfigyelhetőek. A 2016. második felében megjelent „Akkreditált Klaszter” cím elnyerésére vonatkozó AK-2016 kódszámú pályázat is hozott néhány szigorítást a pályázó szervezetekre vonatkozóan. Többek között nagyobb hangsúly esik a már korábban akkreditált klaszterek esetében az akkreditáció legutóbbi elnyerése óta történt közös projektekre, nemzetközi megjelenésekre, együttmüködésekre. A pályázatok elbírálása és a cím odaítélése során az alábbi négy fő szempont kerül részletesen értékelésre:
I. Klaszteren belüli együttmüködés
II. Klasztermenedzsment és a klaszter összetétele
III. Nemzetközi fókusz
IV. Innováció

Az Akkreditált Klaszter cím elnyerése továbbra sem jár közvetlen támogatással, hanem hasonlóan a korábbi gyakorlathoz a Gazdaságfejlesztési és Innovációs Operatív Programon belül vannak olyan pályázatok, amelyekre csak Akkreditált Klaszter pályázhat, míg más források esetében előnyt jelent az akkreditált klaszterben való tagság.

A Professzionális klaszterszervezetek minőségi szolgáltatásnyújtásának támogatása ${ }^{15}$ címü GINOP-1.3.2-15 kódszámú felhívás célja a stabil szakmai és gazdálkodási múlttal rendelkező, fejlődőképes klaszterek támogatása a klasztermenedzsment szervezetek minőségi szolgáltatásnyújtásának és nemzetközi piacra jutásának ösztönzése révén. A pályázatokon 5 és 50 millió Ft közötti támogatás nyerhetnek el a megfelelő háttérrel rendelkező menedzsment szervezetek, különböző szolgáltatások fejlesztésére, információs technológiai beruházásokra, képzésekre, a nemzetközi megjelenéshez és piacra jutáshoz szükséges tevékenységekre. A támogatása odaítélése esetén a klasztereknek bizonyos kötelező vállalásokat kell teljesíteniük, amelyek egyrészről a klasztermenedzsment szervezet létszámának vagy árbevételének növelésére irányulnak, másrészröl elvárásokat fogalmaznak meg a klasztertagság növelésére, valamint nemzetközi klaszterminősítés megszerzésére vagy nemzetközi projektben való részvételre is. Kezdetben a pályázat csak az akkreditált klaszterek számára volt elérhető, de 2017. közepétől kibővítették a pályázók körét azon, legalább 3 éve működő és 1 föt foglalkoztató klasztermenedzsment szervezetek számára, amelyek legalább 15 (minimum 1 éves tagsággal rendelkezö) klasztertag vállalatot tömörítő és a klaszter szakmai teljesítményét mérő pontozási rendszernek is megfelelő klasztert képviselnek.

A fenti dedikált forráson túl a következő gazdaságfejlesztési és $\mathrm{K}+\mathrm{F}+\mathrm{I}$ felhívások esetében jelent előnyt az akkreditált klaszter tagság a támogatási kérelem értékelésekor:

- GINOP-1.2.1-16- Mikro-, kis- és középvállalkozások termelési kapacitásainak bővítése

\footnotetext{
${ }^{15}$ https://www.palyazat.gov.hu/ginop-121-16-mikro-kis-s-kzpvllalkozsok-termelsi-kapacitsainak-bvtse-1
} 
- GINOP-1.2.2-16 - Mikro-, kis- és középvállalkozások kapacitásbővítő beruházásainak támogatása

- GINOP-1.2.3-8.3.4-16 - Mikro-, kis- és középvállalkozások kapacitásbővítő beruházásainak támogatása kombinált hiteltermék keretében ${ }^{16}$

- GINOP-1.2.6-8.3.4-16 - Élelmiszeripari középvállalatok komplex beruházásainak támogatása kombinált hiteltermékkel ${ }^{17}$

- GINOP-1.3.1-15 - Mikro-, kis- és középvállalkozások piaci megjelenésének támogatása ${ }^{18}$

- GINOP-1.3.3-16 - Beszállító mikro-, kis- és középvállalkozások és beszállítói integrátorok támogatása ${ }^{19}$

- GINOP-2.1.4-15 - Innovációs voucher ${ }^{20}$

- GINOP-2.2.1-15 - K+F versenyképességi és kiválósági együttmüködések ${ }^{21}$

A többlépcsős klaszterfejlesztési program tehát a 2014-2020-as programozási időszakban is folytatódik, csak itt már sokkal inkább a 2007-2013 között létrehozott, megerősített és minősített klaszterek további növekedésének és nemzetközi megjelenésének a támogatása a cél annak érdekében, hogy ne csak hazánkban, de nemzetközi színtéren is sikereket érjenek el és bekapcsolódjanak a különböző európai és világszínvonalú klaszteres programokba, platformokba. Az előző programozási időszak klaszterfejlesztési programjával kapcsolatban számos kritika fogalmazódott meg arra vonatkozóan, hogy túl sok klaszter létrejöttét támogatta, sokszor hasonló területeken párhuzamosan, a regionális források központi koordinációjának hiányából adódóan. További problémaként merült fel, hogy nagyon sok „forrásvadász” klaszterkezdeményezés jött létre kizárólag a pályázati pénzek lehívására. Ennek megfelelően és az új gazdaságfejlesztési prioritásokhoz igazodva, 2014-től már nem kerülnek pénzügyileg támogatásra az induló klaszterek. Ez nem azt jelenti, hogy önerőből nem alakulhatnak ki, csak nem kapnak ehhez célzott támogatást. Ennek az időszaknak a kiemelt célja a legfontosabb iparágakban meglévő magas innovációs potenciállal rendelkező klaszterek erősítése és nemzetközi láthatóvá tétele, annak érdekében, hogy olyan hazai csúcsklaszterek jöjjenek létre, amelyek megállják a helyüket a globális versenyben is. Az alábbi 5. ábra a 1990 és 2020 között rendelkezésre álló klaszterfejlesztési támogatásokat foglalja össze.

\footnotetext{
${ }^{16}$ https://www.palyazat.gov.hu/ginop-122-16-mikro-kis-s-kzpvllalkozsok-kapacitsbvt-beruhzsainak-tmogatsa-1

${ }^{17}$ https://www.palyazat.gov.hu/ginop-126-834-16-lelmiszeripari-kzpvllalatok-komplex-beruhzsainak-tmogatsakombinlt-hiteltermkkel

${ }^{18} \mathrm{https}: / /$ www.palyazat.gov.hu/doc/4463

${ }^{19} \mathrm{https} / / /$ www.palyazat.gov.hu/ginop-133-16-beszllt-mikro-kis-s-kzpvllalkozsok-s-beszllti-integrtorok-tmogatsa

${ }^{20} \mathrm{https} / / / \mathrm{www}$.palyazat.gov.hu/ginop-214-15-innovcis-voucher

${ }^{21} \mathrm{https}$ ://www.palyazat.gov.hu/doc/4516
} 


\section{5. ábra A klaszterfejlesztést támogató források Magyarországon 1990-2020 között}
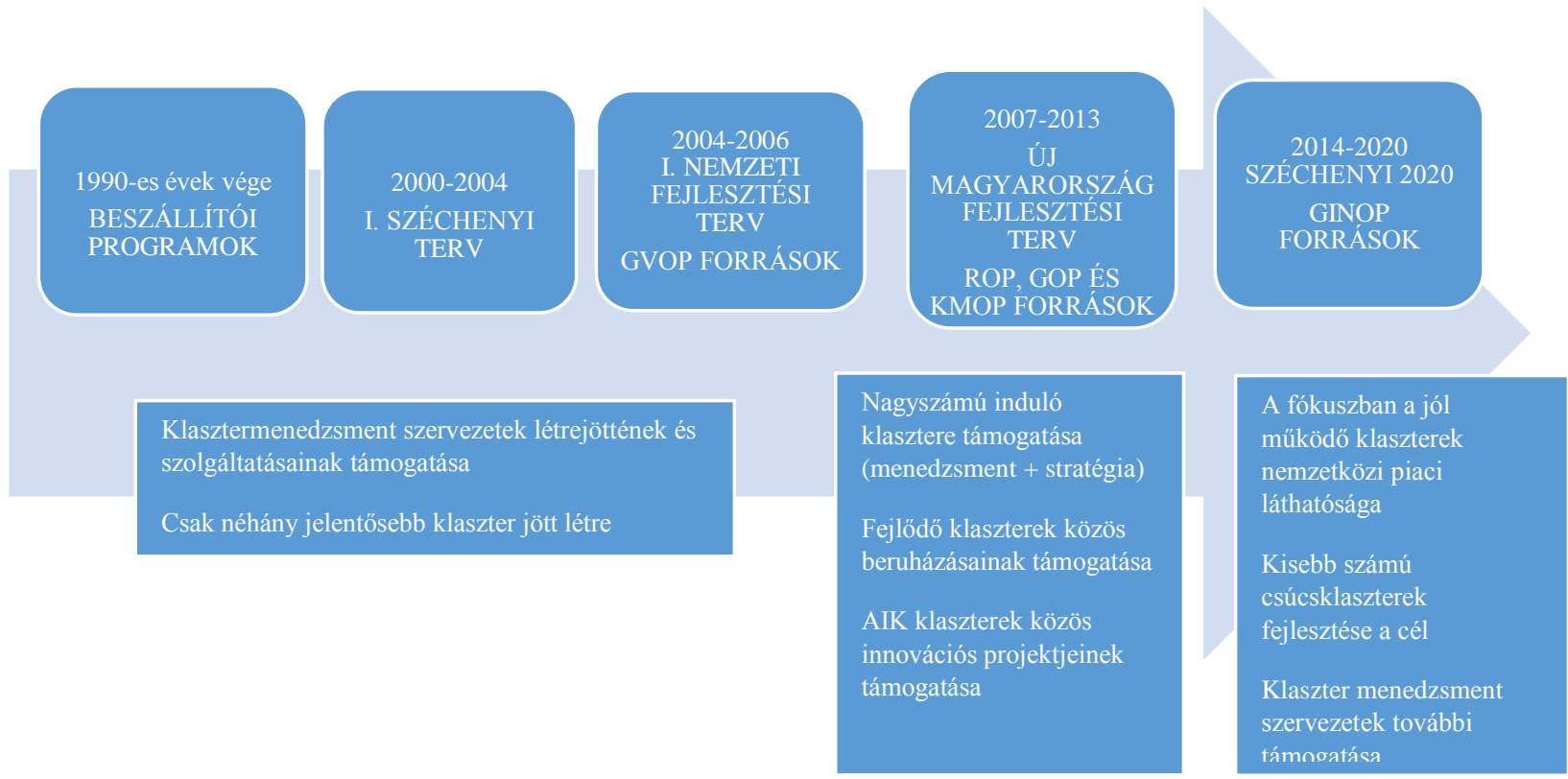

Forrás: Saját szerkesztés

Láthatjuk, hogy az 1990-es évek végétől kezdődően egyre célzottabb és koncentráltabb klasztertámogatási rendszer épült fel Magyarországon. Jellemzően a különböző programozási időszakok gazdaságfejlesztési programjai biztosították a klaszterek fejlődéséhez szükséges forrásokat. A klaszteresedési folyamatokban igazi áttörést azonban a 2007-2013-as programozási időszak forrásai hoztak. Ekkor indult meg a legintenzívebben a klaszterek létrejötte és fejlődése, melynek köszönhetően soha nem látott nagyságrendben jöttek létre a különböző régiókban a klaszterek. A viszonylagos forrásböség eredményeként azonban számos együttmüködést csak a pályázati pénzek elnyerése ösztönzött, így azok a támogatási források csökkenésével megszüntek vagy „hibernált” állapotba kerültek. Voltak azonban olyan klaszterek, akik végigmenve a klaszterfejlödés különböző szintjein, a közös stratégiák, szervezeti háttér, fejlesztések és beruházások révén, stabil együttmüködési hátteret alakítottak ki és jó eséllyel, akár hosszú távon tudnak müködni és nemzetközi szinten is láthatóvá válni. 


\subsection{A klaszterek földrajzi jellemzői, teljesítménye}

A 2007 és 2013 között zajló komplex klaszterfejlesztési program eredményeként összesen 172 induló és 38 fejlődő együttmüködés került támogatásra a Regionális Operatív Programokból közel 8 milliárd pályázati forrás bevonásával. A támogatásban részesített induló és fejlődő klaszterek regionális megoszlását a 6. ábra szemlélteti, melyböl látható, hogy a legtöbb induló, majd fejlődő együttműködés Közép-Magyarországon, ÉszakMagyarországon és a Dél-Alföldön jött létre ebben az időszakban (COLOSSEUM BUDAPEST KFT. 2015).

\section{6. ábra A támogatásban részesített induló és fejlődő klaszterek száma (db) regionális megoszlásban}

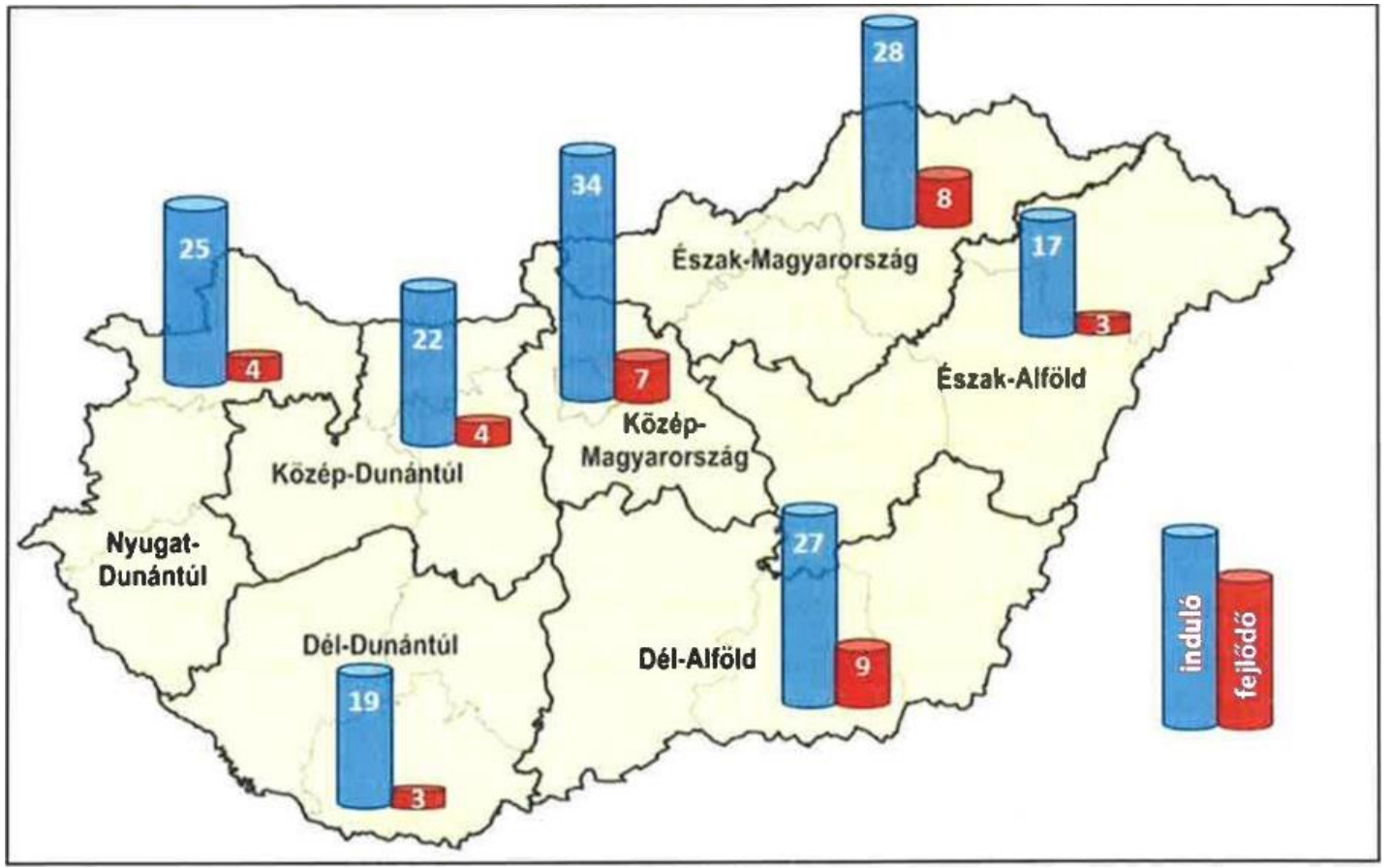

Forrás: Colosseum Budapest 2015

Az Akkreditált Klasztereket tekintve a 2007-2013-as támogatási időszakban összesen 34 klaszter nyerte el az akkreditációs címet, melyek közel 1140 vállalkozást és 117000 foglalkoztatottat tömörítettek magukba, árbevételük pedig elérte a 9,5 milliárd forintot. Az Akkreditált Klaszterek a Nemzetgazdasági Minisztérium által történő iparágankénti besorolását és területi megoszlását a 7 . ábra mutatja, miszerint a legtöbb együttmüködés a dinamikusan fejlődő infokommunikációs iparág, a nagy autóipari cégekhez kapcsolódó gépipar, jármüipar, továbbá az egészségügy területén jött létre. A földrajzi eloszlást tekintve Közép-Magyarország, Dél-Alföld, Észak-Alföld és Közép-Dunántúl jelentenek egyfajta csomósodási pontokat (NGM GFP HÁT NEMZETKÖZI ÉS KLASZTER OSZTÁLY 2014). 


\section{7. ábra Az akkreditált klaszterek iparágankénti és területi megoszlása 2015-ben}

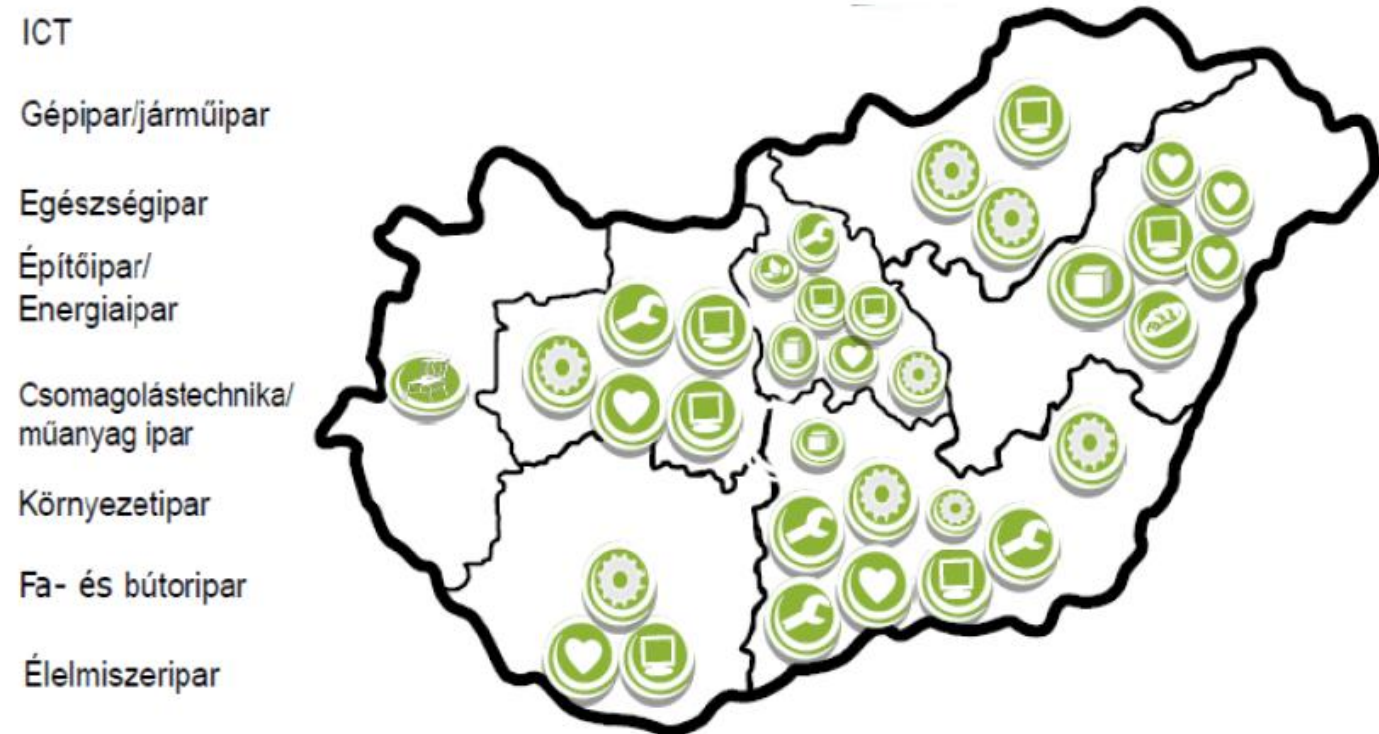

Forrás: NGM GFP HÁT, Nemzetközi és Klaszter Osztály 2014

Mivel a klaszterek 2 éves időtartamra kapják meg az akkreditált címet, így azok száma és listája is dinamikusan változó. A 2. táblázat az akkreditált klaszterek listáját, továbbá azok legfontosabb adatait mutatja 2015-re vonatkozóan.

A legtöbb akkreditált klaszter átlagosan 30-50 taggal múködik, persze vannak ennél jóval nagyobb, akár 76 tagot magukban tömörítő klaszterek is. Ez a taglétszám a Magyarországon létrejött klasztereket tekintve figyelemre méltó ugyan, de még mindig messze elmarad a nemzetközi gyakorlattól, ahol akár több száz fős, országos szintű klaszterek müködnek. A klasztertagok 90\%-a vállalkozás, melyek között több nagyvállalat és számos kis-és középvállalkozás is található és az előminősítési vagy klaszter akkreditációs eljárás elvárásainak megfelelően ezekben a klaszterekben nagymértékben koncentrálódnak az innovatív vállalkozások. Szinte minden klaszterben részt vesz továbbá valamilyen felsőoktatási intézmény, kutatóintézet, amely összetétel nagyban erősíti a kutatás-fejlesztési kooperációt és a technológia-transzfer folyamatokat a szereplők között. A klaszterek operatív irányítását és a menedzsment feladatokat külön gazdasági társaság, úgynevezett klaszter menedzsment szervezet végzi. A klaszter menedzsment szervezetek különböző szolgáltatásokkal támogatják a klasztertagokat a klaszteren belüli együttmüködés ösztönzése, az egységes hazai és nemzetközi piaci megjelenés és a forrásbevonás képesség fokozása érdekében. A 34 klaszter közül 7 klaszter müködik a központi régióban, de a legtöbb konvergencia régióbeli klaszter is számos közép-magyarországi székhelyü taggal rendelkezik, hiszen az országos lefedettség érdekében, igyekeztek bevonni az adott iparág legjelentősebb képviselöit, amelyek sok esetben Budapesten vagy Pest megyében müködnek. A földrajzilag szerteágazó tagság mellett az akkreditált klaszterek legjelentősebb kutatás-fejlesztési projektjeiket, mégis a klaszterek magját jelentő tudásközpontokban pl. (Szeged, Budapest, Debrecen, Miskolc...stb) valósították meg, ezzel is hozzájárulva ezen városok tudásteremtésben és tudásáramlásban betöltött szerepének erősödéséhez. 


\section{2. táblázat Akkreditált klaszterek listája és legfőbb adataik (az akkreditációs pályázatuk benyújtásának időpontjában)}

\begin{tabular}{|c|c|c|c|c|c|}
\hline Klaszter neve & $\begin{array}{l}\text { Tagok } \\
\text { száma } \\
\text { (db) }\end{array}$ & $\begin{array}{l}\text { Tag- } \\
\text { vállalatok } \\
\text { száma } \\
\text { (db) }\end{array}$ & $\begin{array}{l}\text { Átlagos } \\
\text { stat. } \\
\text { létszám } \\
\text { (fó) }\end{array}$ & $\begin{array}{c}\text { Éves } \\
\text { Nettó } \\
\text { árbevétel } \\
\text { (Mrd. } \\
\text { Ft.) }\end{array}$ & $\begin{array}{c}\text { Export } \\
\text { bevétel } \\
\text { (Mrd. } \\
\text { Ft) }\end{array}$ \\
\hline 3P Műanyagipari, Csomagolástechnikai, Nyomdaipari Klaszter & 28 & 25 & 1326 & 22,22 & 6,19 \\
\hline AIPA Alföldi Regionális Iparfejlesztési Klaszter & 28 & 22 & 3646 & 134,99 & 84,26 \\
\hline Alliance Informatikai és Innovációs Klaszter & 47 & 43 & 4234 & 332,54 & 175,35 \\
\hline $\begin{array}{l}\text { ArchEnerg Regionális Megújuló Energetikai és Építőipari } \\
\text { Klaszter }\end{array}$ & 60 & 59 & 6939 & 168,29 & 27,54 \\
\hline Bakony-Balaton Mechatronikai és Jármüipari Klaszter & 36 & 31 & 9009 & 360,42 & 334,18 \\
\hline Biotechnológiai Innovációs Bázis Klaszter & 23 & 20 & 280 & 7,68 & 1,07 \\
\hline $\begin{array}{l}\text { Csomagolástechnikai Innovációs és Környezetgazdálkodási } \\
\text { Klaszter }\end{array}$ & 25 & 25 & 968 & 34,07 & 24,2 \\
\hline Dél-Dunántúli Gépipari Klaszter & 21 & 19 & 2180 & 57,37 & 47,51 \\
\hline $\begin{array}{l}\text { Építőipari Kutatási Innovációs és Technológia- Transzfer } \\
\text { Klaszter }\end{array}$ & 29 & 29 & 1096 & 31,95 & 17,12 \\
\hline Észak-Alföldi Termál Klaszter & 45 & 31 & 3331 & 35,76 & 6,94 \\
\hline Észak-magyarországi Autóipari Klaszter & 73 & 66 & 11152 & 350,66 & 285,94 \\
\hline Észak-Magyarországi Informatikai Klaszter & 42 & 40 & 2811 & 166,92 & 146,44 \\
\hline Goodwill Biotechnológiai Klaszter & 28 & 25 & 688 & 16,94 & 0,66 \\
\hline Hírös Beszállítói Klaszter & 23 & 22 & 4584 & 135,91 & 122,48 \\
\hline Információmenedzsment Innovációs Klaszter & 29 & 29 & 365 & 5,58 & 0,73 \\
\hline Innoskart IKT Klaszter & 37 & 37 & 915 & 24,14 & 5,01 \\
\hline KEXPORT Klaszter & 21 & 21 & 724 & 20,54 & 4,35 \\
\hline Magyar Autóbuszgyártó Klaszter & 31 & 29 & 1251 & 24,35 & 10,05 \\
\hline Magyar Medikai Gyártók és Szolgáltatók Klaszter & 35 & 34 & 955 & 15,11 & 7,42 \\
\hline Magyar Sport- és Életmódfejlesztő Klaszter & 34 & 28 & 573 & 297,53 & 175,20 \\
\hline Magyar Üripari Klaszter & 30 & 21 & 519 & 7,42 & 3,27 \\
\hline MIÉNK Klaszter & 46 & 46 & 908 & 79,57 & 11,75 \\
\hline Mobilitás és Multimédia Klaszter & 61 & 51 & 835 & 522,78 & 51,37 \\
\hline Omnipack Első Magyar Csomagolástechnikai Klaszter & 22 & 22 & 362 & 7,88 & 2,93 \\
\hline ÖKOPolisz Klaszter & 59 & 49 & 704 & 523,19 & 66,21 \\
\hline Pannon Fa- és Bútoripari Klaszter & 45 & 37 & 358 & 41,44 & 9,83 \\
\hline Pharmagora Életminőség Klaszter & 26 & 22 & 818 & 25,64 & 8,63 \\
\hline Pharmapolis Debrecen Innovatív Gyógyszeripari Klaszter & 24 & 19 & 844 & 363,29 & 231,00 \\
\hline Pharmapolis Innovatív Élelmiszeripari Klaszter & 76 & 70 & 245 & 273,18 & 63,49 \\
\hline Rendszertudományi Innovációs Klaszter & 31 & 27 & 671 & 92,34 & 8,80 \\
\hline Sárrét Metál Klaszter & 26 & 25 & 257 & 19,44 & 13,15 \\
\hline Szilícium Mező Regionális Informatikai Klaszter & 44 & 42 & 914 & 157,64 & 130,46 \\
\hline Szoftveripari Innovációs Pólus Klaszter & 48 & 46 & 584 & 31,86 & 5,67 \\
\hline Zöld Áramlat megújuló Energetikai és Innovációs Klaszter & 28 & 28 & 786 & 153,81 & 112,12 \\
\hline Összesen & 1261 & 1140 & 116832 & 9542,44 & 2201,34 \\
\hline
\end{tabular}


Egy 2013-ban készült klaszteres vizsgálat során Horváth és szerzőtársai az akkreditált klaszterek térbeli sürüsödését vizsgálva, térben szétterülö, szatellit-körzet típusú, fővárosra koncentráló, valamint valódi regionális klasztereket azonosítottak és ez alapján egyetlen klaszter müködött a térbeli közelség elönyeit kihasználó regionális klaszterként, míg a többiek térben nagyon kiterjedtek, ezáltal nagyobb fizikai távolságokat kell áthidalniuk a müködésük során. A térben szétterülő klaszterek a biotechnológiai, élelmiszeripari, építőipari, infokommunikációs és a kreatív- és kulturális ágazatok klaszterei. Szatellit körzet típusúnak a jármüipari klasztert tekintették, a fővárosra koncentrálódóak az orvosi müszergyártó, a telekommunikációs, valamint a papír- és mủanyagipari klaszterek voltak, míg az üzleti szolgáltatások területén müködött az egyetlen regionális klaszter (HORVÁTH, M. et al. 2013).

Az Akkreditált Klaszterek beváltották az innováció ösztönzésével kapcsolatban hozzájuk füzött reményeket, hiszen összességében mintegy 200 feletti innovációs projektet valósítottak meg 2007 és 2013 között és a Gazdaságfejlesztési Operatív Program K+F prioritásában megítélt támogatások nagyjából 24\%-át az akkreditált klaszterek tagvállalatai nyerték el. Nem csak a kutatás-fejlesztés és az innováció területén mutattak fel jelentős eredményeket ezek a minősített együttmüködések, de az összes gazdaságfejlesztési célú pályázatot tekintve is kiemelkedő arányt képviselnek. Ahogyan azt a 8. ábra mutatja az Akkreditált Klaszterek tagvállalatai összesen (2013 év végégig) 127 Mrd Ft-nyi támogatást nyertek el a GOP és a KMOP gazdaságfejlesztési célú pályázataiból, melynek nagyjából $73 \%$-a K+F+I támogatás és $27 \%$-a egyéb gazdaságfejlesztési célú forrás. Az összes vállalat pályázati eredményességét a 9. ábra szemlélteti, mely szerint az összes gazdaságfejlesztési forrást elnyert vállalatok mintegy $18 \%$-a klaszter tagvállalat.

\section{8. ábra AIK Klaszterek tagvállalatai által elnyert gazdaságfejlesztési célú támogatás (Mrd Ft, 2013 novemberi adat)}

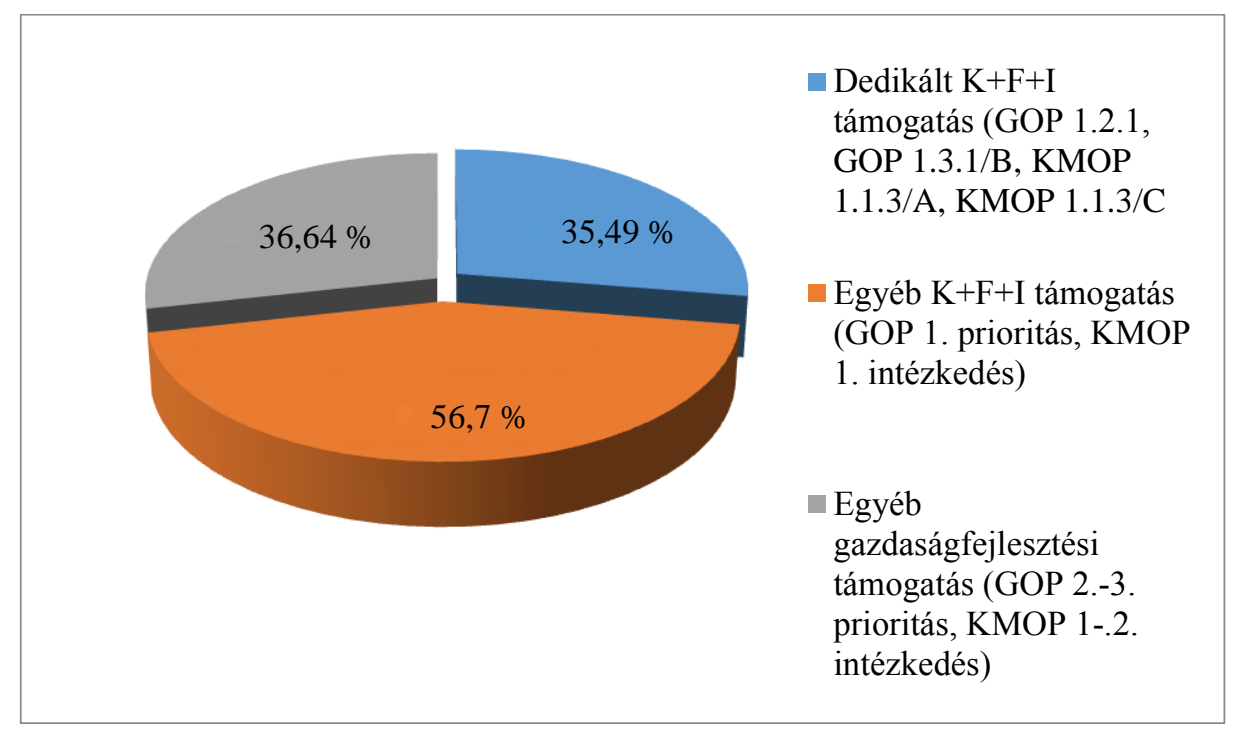

Forrás: PM GFP HÁT Nemzetközi és Klaszter Osztály adatbázisa alapján saját szerkesztés 


\section{9. ábra Klaszter-tagvállalatok által elnyert támogatás aránya a gazdaságfejlesztési pályázatokon belül $(\%, 2013$. novemberi adat $)$}

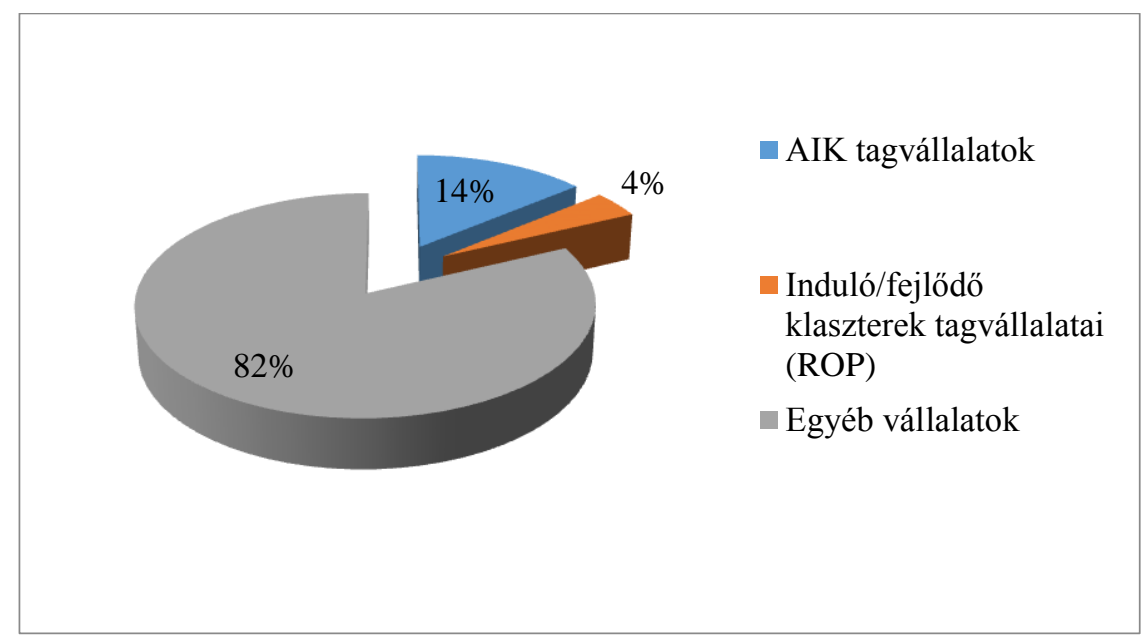

Forrás: PM GFP HÁT Nemzetközi és Klaszter Osztály adatbázisa alapján saját szerkesztés

A 2013-as gazdaságfejlesztési és $\mathrm{K}+\mathrm{F}+\mathrm{I}$ források felhasználására vonatkozó adatok (10. ábra és 11. ábra) is azt mutatják, hogy a regionális központokban jelentős arányban nyertek el forrásokat ezek az együttmüködések. Különösen igaz ez a $\mathrm{K}+\mathrm{F}+\mathrm{I}$ támogatásokra, hiszen a nagyobb tudásközpontokban ezeknek a forrásoknak átlagosan az 1/3-át nyerték el a klasztertagok, továbbá a kisebb városokban, például Székesfehérváron az akkreditált klaszter tagok forráslehívási képessége arányában igen magas volt és majdnem elérte az egyéb vállalkozásokét. A regionális központok közül Szeged teljesítményét emelném még ki, hiszen nemcsak Csongrád megye szerepelt kiemelkedően jól a gazdaságfejlesztési források lehívását illetően, de ezen belül Szeged, mint regionális tudásközpont szerepe is megerösítést nyert, hiszen a vállalkozások és köztük az Akkreditált klaszterek tagjai is igen magas arányban nyertek el különböző gazdaságfejlesztési és kutatásfejlesztési forrásokat. (NGM GFP HÁT NemZetKöZI És KlaszTer OsztÁly 2014, Colosseum BudaPest KFT. 2015).

10. ábra Az Akkreditált Innovációs Klaszter Tagvállalatok által elnyert gazdaságfejlesztési források aránya a regionális központokban (Mrd Ft, 2013 november)

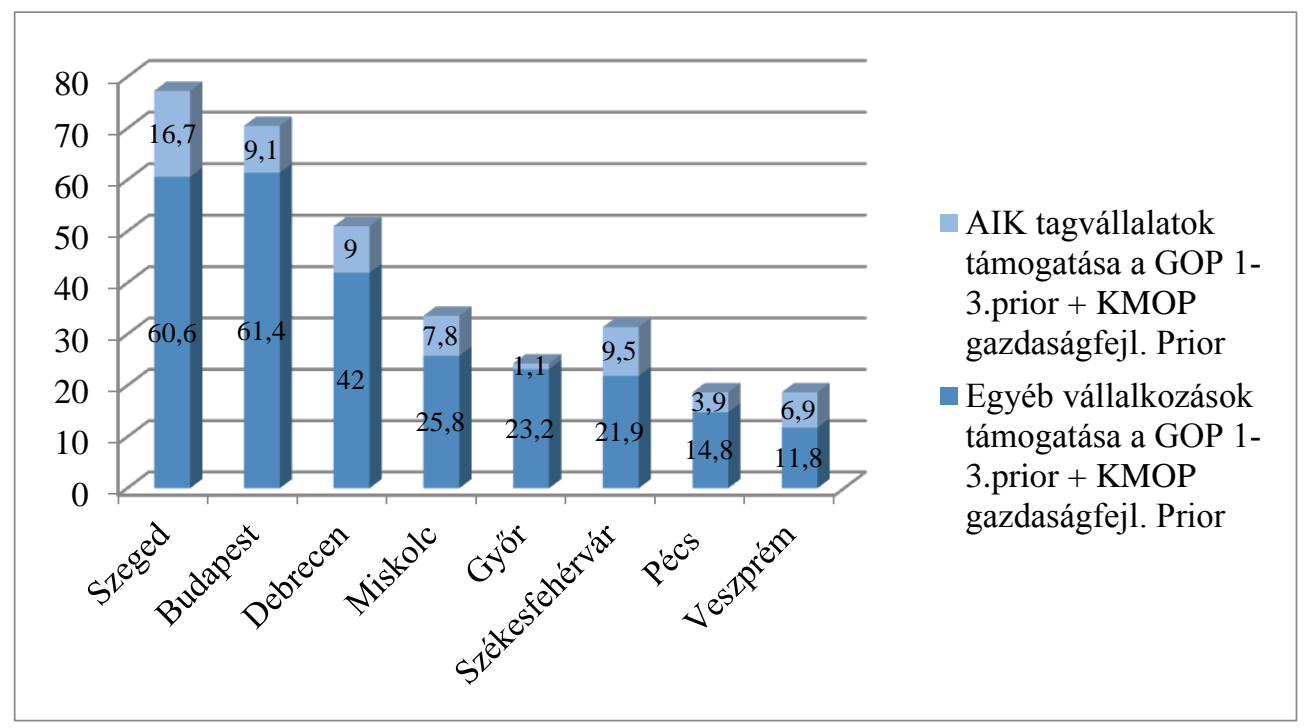

Forrás: PM GFP HÁT Nemzetközi és Klaszter Osztály adatbázisa alapján saját szerkesztés 


\section{1. ábra Az Akkreditált Innovációs Klaszter Tagvállalatok által elnyert $K+F+I$ célú források aránya a regionális központokban (Mrd Ft, 2013 november)}

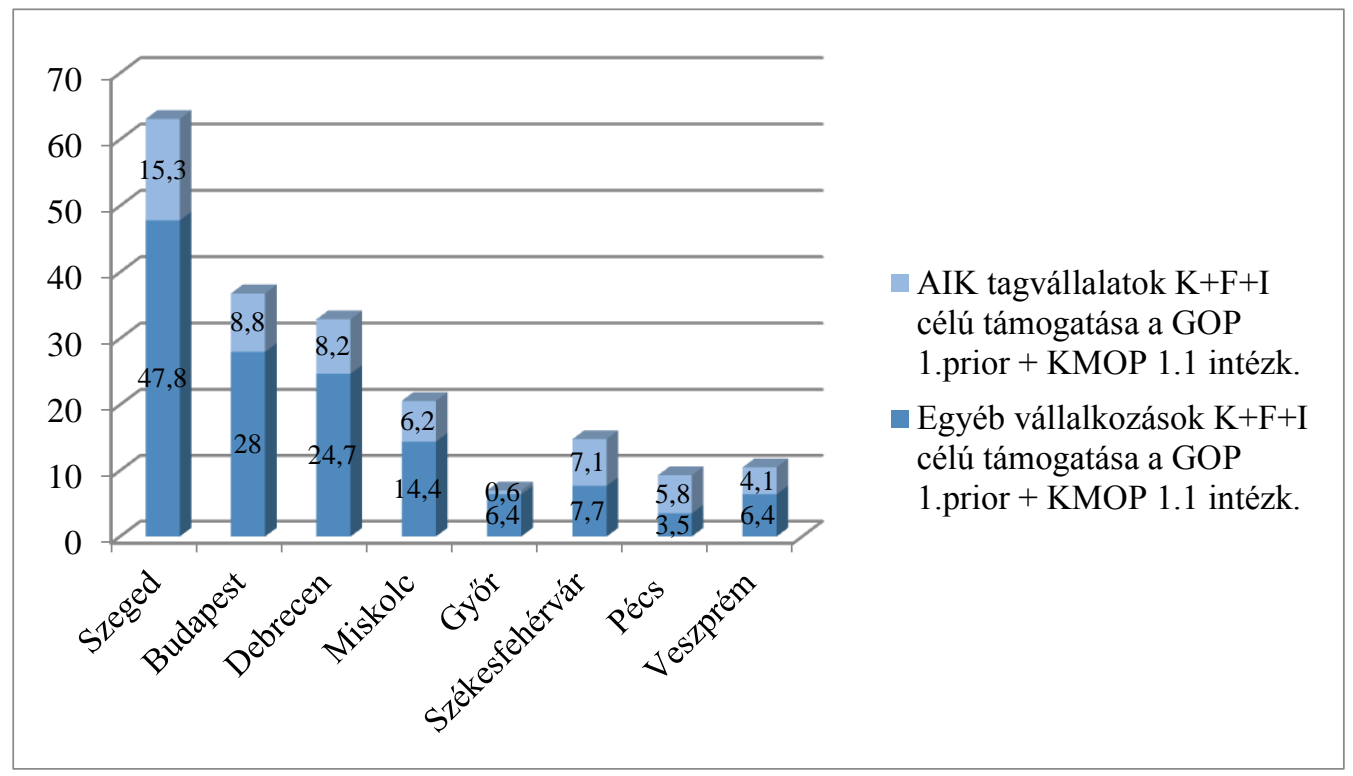

Forrás: PM GFP HÁT Nemzetközi és Klaszter Osztály adatbázisa alapján saját szerkesztés

A 2007-2013-as gazdaságfejlesztési források felhasználási sikerességét vizsgálva az is bebizonyosodott, hogy az akkreditált klaszterek és azok tagjai megbízhatóbb pályázóknak számítanak, mivel az átlagosnál nagyobb arányban valósították meg sikeresen a támogatott projekteket és számoltak el a folyósított pénzügyi támogatással. Visszaigazolást nyert ezáltal a szigorú minősítési eljárás szükségessége és eredményessége, hiszen ezekhez a klaszterekhez a jelentős gazdasági múlttal és eredményekkel rendelkező vállalkozások csatlakozhattak, illetve a klaszter menedzserek állandó és hathatós segítsége is hozzájárulhatott ehhez a sikerhez (COLOSSEUM BUDAPEST KFT. 2015).

Az Akkreditált klaszterek körében 2014-től kezdődően egy természetes koncentrálódási folyamat kezdődött meg és már két esetben is történtek összeolvadások. Az egyik esetben az INNOSKART és a PharmAgora klaszterek, a másik esetben pedig a dél-alföldi székhelyü 3P és AIPA klaszterek egyesültek. Az összeolvadások lehetőséget adnak a nemzetközi szinten is fontos ágazatok közötti együttmüködésekre és ennek köszönhetően a klaszterek nagysága és taglétszáma is egyre inkább közelít a nemzetközi szinten is vonzó mérethez. A koncentrálódási folyamatok és néhány lemorzsolódás eredményeként a korábbi 2013-as 34hez képest jelenleg 26 akkreditált klaszter müködik, amelyek átlagos taglétszáma azonban meghaladja a 2013. évi állapotot (3. táblázat). 


\section{3. táblázat Az akkreditált klaszterek legfontosabb adatai (2018-ra vonatkozóan)}

\begin{tabular}{|c|c|c|c|c|}
\hline Klaszter neve & $\begin{array}{c}\text { Tagok } \\
\text { száma } \\
\text { (db) }\end{array}$ & $\begin{array}{l}\text { Tag- } \\
\text { vállalatok } \\
\text { száma } \\
\text { (db) }\end{array}$ & $\begin{array}{c}\text { Nettó } \\
\text { árbevétel } \\
\text { (Mrd Ft) }\end{array}$ & $\begin{array}{l}\text { Export } \\
\text { bevétel } \\
\text { (Mrd Ft) }\end{array}$ \\
\hline AI3PA SMART Klaszter & 51 & 48 & 198,3 & 91,53 \\
\hline Alliance Informatikai és Innovációs Klaszter & 44 & 42 & 37,77 & 0,83 \\
\hline $\begin{array}{l}\text { Archenerg Nemzetközi Megújuló Energetikai és Építőipari } \\
\text { Innovációs Klaszter }\end{array}$ & 79 & 78 & 193,6 & 31,71 \\
\hline Biotechnológiai Innovációs Bázis Klaszter & 28 & 26 & 6,89 & 1,07 \\
\hline Dél-dunántúli Gépipari Klaszter & 27 & 24 & 82,88 & 64,11 \\
\hline Dél-dunántúli Regionális Élelmiszer Innovációs Klaszter & 27 & 24 & 93,7 & 26,16 \\
\hline Észak-magyarországi Informatikai Klaszter & 45 & 42 & 201,94 & 173,36 \\
\hline Hírös Beszállítói Klaszter & 31 & 30 & 143,25 & 111,14 \\
\hline Információmenedzsment Innovációs Klaszter & 33 & 31 & 113,88 & 1,22 \\
\hline Innoskart IKT Klaszter & 65 & 60 & 61,54 & 15,34 \\
\hline Magyar Medikai Gyártók és Szolgáltatók Klaszter & 42 & 40 & 37,18 & 16,03 \\
\hline Magyar Sport- és Életmódfejlesztő Klaszter & 31 & 26 & 293,44 & 248,18 \\
\hline MIRBEST Közép-európai Gasztroinnovációs Klaszter & 20 & 20 & 82,85 & 4,02 \\
\hline NOHAC Észak-magyarországi Autóipari Klaszter & 74 & 66 & 646,96 & 506,39 \\
\hline OMNIPACK Első Magyar Csomagolástechnikai Klaszter & 22 & 21 & 21,1 & 12,82 \\
\hline Ökopolisz Klaszter & 47 & 44 & 4272,83 & 463,12 \\
\hline Pannon Fa- és Bútoripari Akkreditált Innovációs Klaszter & 39 & 31 & 29,46 & 13,55 \\
\hline Pharmapolis Debrecen Innovatív Gyógyszeripari Klaszter & 26 & 21 & 289,96 & 248,52 \\
\hline Pharmapolis Innovatív Élelmiszeripari Klaszter & 75 & 69 & 338,15 & 93,92 \\
\hline Professio Fémipari és Szakképzési Klaszter & 24 & 21 & 138,15 & 113,02 \\
\hline Rendszertudományi Innovációs Klaszter & 27 & 23 & 137,6 & 5,34 \\
\hline Sárrét Metál Klaszter & 29 & 28 & 126,76 & 18,58 \\
\hline Szilícium Mező Regionális Informatikai Klaszter & 34 & 32 & 196,27 & 169,5 \\
\hline Szoftveripari Innovációs Pólus Klaszter & 37 & 35 & 29,68 & 6,97 \\
\hline Termál-Egészségipari Klaszter & 41 & 32 & 45,58 & 6,62 \\
\hline Víz- és Környezetgazdálkodási Klaszter & 22 & 20 & 22,59 & 1,39 \\
\hline Összesen & 1020 & 934 & 7842,31 & 2444,44 \\
\hline
\end{tabular}

Forrás: PM GFP HÁT Nemzetközi és Klaszter Osztály adatbázisa alapján saját szerkesztés 
Az akkreditált klaszterek kis-és középvállalkozás (KKV) minősítésü tagvállalatainak adatait vizsgálva (4. táblázat) látható, hogy a jelenleg müködő 26 klaszter KKV tagvállalatainak árbevétele és export árbevétele is meghaladja a 2013-ban müködö 34 klaszter ugyanezen tagvállalatainak adatait, tehát az akkreditált klaszterek körében egyfajta erösödés figyelhető meg a KKV-k gazdasági teljesítményét illetően, amely egy nagyon pozitív tendencia, hiszen a nemzetközi piacokon is versenyképes klaszterek csak erős vállalkozói bázissal tudnak müködni.

\section{4. táblázat Akkreditált klaszterek KKV tagvállalatainak gazdálkodási adatai}

\begin{tabular}{|l|l|l|l|l|}
\hline \multicolumn{5}{|c|}{ Akkreditált Klaszterek } \\
\hline & $\begin{array}{l}\text { Klaszterek } \\
\text { száma (db) }\end{array}$ & $\begin{array}{l}\text { KKV-k } \\
\text { száma (db) }\end{array}$ & $\begin{array}{l}\text { KKV-k } \\
\text { árbevétele }\end{array}$ & $\begin{array}{l}\text { KKV-k } \\
\text { export } \\
\text { árbevétele }\end{array}$ \\
\hline $\mathbf{2 0 1 3}$ & 34 & 1011 & $903,9 *$ & 228,7 \\
\hline $\mathbf{2 0 1 8}^{\mathbf{2 2}}$ & 26 & 848 & 1258,9 & 252,8 \\
\hline
\end{tabular}

Forrás: PM GFP HÁT Nemzetközi és Klaszter Osztály adatbázisa alapján saját szerkesztés

Összességében hazai szinten kiemelkedő számban jöttek létre változatos szakterületeken és iparágakban müködő klaszterek, melyek területi eloszlása néhány régió átlagosnál valamivel kiemelkedőbb szerepe mellett mégis egyenletesnek tekinthető. Az induló klaszterek egy része tovább tudott lépni a fejlődő szakaszba, jelentős értékü közös gazdaságfejlesztési és kutatási projektet megvalósítva és a létrejött klaszter együttmüködések mintegy $10 \%$-a mára már stabil vállalkozó háttérrel rendelkező, innovatív, versenyképes együttmüködésnek tekinthető.

22 A 2018. január 31-i állapot szerinti akkreditált klaszterek esetében a klaszter tagvállalatok gazdálkodási adatainál a 2015. évi adatok állnak rendelkezésre 


\subsection{Klaszterek a Dél-alföldi Régióban}

Az országos tendenciához hasonlóan a Dél-alföldi Régióban található klaszterek kialakulására is jellemző, hogy néhány egyedi esettől eltekintve, főként a különböző támogatási programok és pályázati források megjelenéséhez köthető a létrejöttük. Az első klaszter alapítási hullám, amely még jóval szerényebb volt a közelmúltban érzékelhetőhöz képest, az I. Széchenyi Terv klaszteres forrásaihoz volt köthető. Az ebben az időszakban létrejött klaszterek közül, kizárólag egy mutat ma aktív müködést a régióban. A további hálózati együttműködésre irányuló kezdeményezések valószínűleg a támogatási források megszünéséből és a közös piaci és gazdasági érdekek hiányából eredően az évek során elhaltak. A 2007-2013-as klaszterfejlesztési program támogatásai a Dél-alföldi Régióban különösen nagy lendületet adtak a klaszterek megalakulásához. A Dél-alföldi Regionális Operatív Programból 2 körben, elöször 2008-ban, majd 2011-ben kaphattak pályázati támogatást az induló és a fejlődő klaszterek. Az első hullámban 2008-ban 23 klaszter kapott forrást, föként a megalakulásra és a közös stratégiák, tervek és a közös tevékenységek elindítására. A második pályázati konstrukciót 2011-ben hirdették meg, mely további 26 újabb klaszter megjelenését, illetve fejlödését ösztönözte, illetve 4 olyan klaszter volt, aki mindkét pályázati körben részesült támogatásban.

Az országos átlagot meghaladóan összesen 51 db klaszter együttmüködés jött létre a régióban a pénzügyi forrásoknak és a klasztereket támogató üzleti környezetnek köszönhetően. Az 1. sz. mellékletben szerepeltettem a Dél-alföldi Régióban létrejött klaszterek teljes listáját, különböző színkódokkal megjelölve a támogatás évét.

A legtöbb klaszter létrejötte Szegedhez köthető és ezeken belül is kiemelkedő szerepe van az egyetem és a kutatóintézetek tudományos területeinek (szoftveripar, biotechnológia, megújuló energia, környezetipar...stb.) eredményeire épülő együttmüködéseknek. Kecskeméten és környékén a hagyományos ipar, tehát a nyomdaipar, csomagolástechnika, müanyagipar, gépipar és építőipar, továbbá az ezeket a területeket kiszolgáló fejlesztési és beszállítói tevékenységek köré épültek a klaszterek. A békéscsabai székhelyü klaszterek a gépipar, az élelmiszeripar, a logisztika, az egészségturizmus területein müködnek, míg Hódmezővásárhelyen komoly múlttal és tapasztalatokkal rendelkező hálózatok alakult ki a textilipar, gépipar és az építőipar mentén. A klaszterek a legjelentősebb tudáscentrumok és ipari termelési zónák köré szerveződtek. A klaszterek specializációi jól illeszkednek a Nemzeti Intelligens Szakosodási Stratégiában (továbbiakban S3 stratégia) megfogalmazott nemzeti prioritásokhoz (Egészséges társadalom és jólét, Fejlett jármü- és egyéb gépipari technológiák, Tiszta és megújuló energiák, Egészséges és helyi élelmiszerek, Agrárinnováció, IKT és Szolgáltatások). Lefedik továbbá a Csongrád, Bács-Kiskun és Békés megyei Területfejlesztési Koncepciókban és az S3 megyei specializációiban megjelölt intelligens technológiák és iparágak nagy részét pl. korszerü csomagolástechnikai technológiák, építőipar, fotonika, lézertechnológia, modern anyagtechnológiák, logisztika,

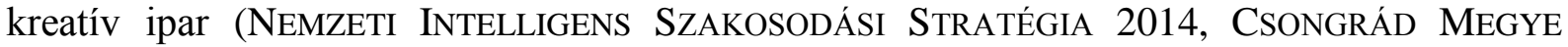

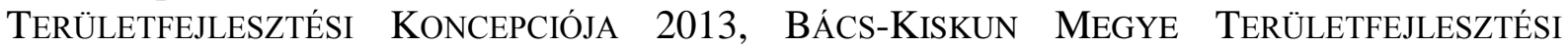
KONCEPCIÓJA 2013, BÉKÉS MEGYE TERÜLETFEJLESZTÉSI KONCEPCIÓJA 2013).

Az iparági megoszlást tekintve tehát (12. ábra) a legnagyobb számban az egészségipar, egészségturizmus, az építőipar és a jármüipar területén alakultak ki klaszterek, de ezen területek mellett kiemelkedő még az élelmiszeripar, szoftveripar, biotechnológia és az energetika is. Összességében szinte minden iparághoz, szakmai vagy tudományos területhez kapcsolódóan létrejött klaszter a régióban, sokszor akár párhuzamosan más magyarországi régiókkal. 
12. ábra A Dél-alföldi Régióban létrejött klaszterek száma iparáganként (db)

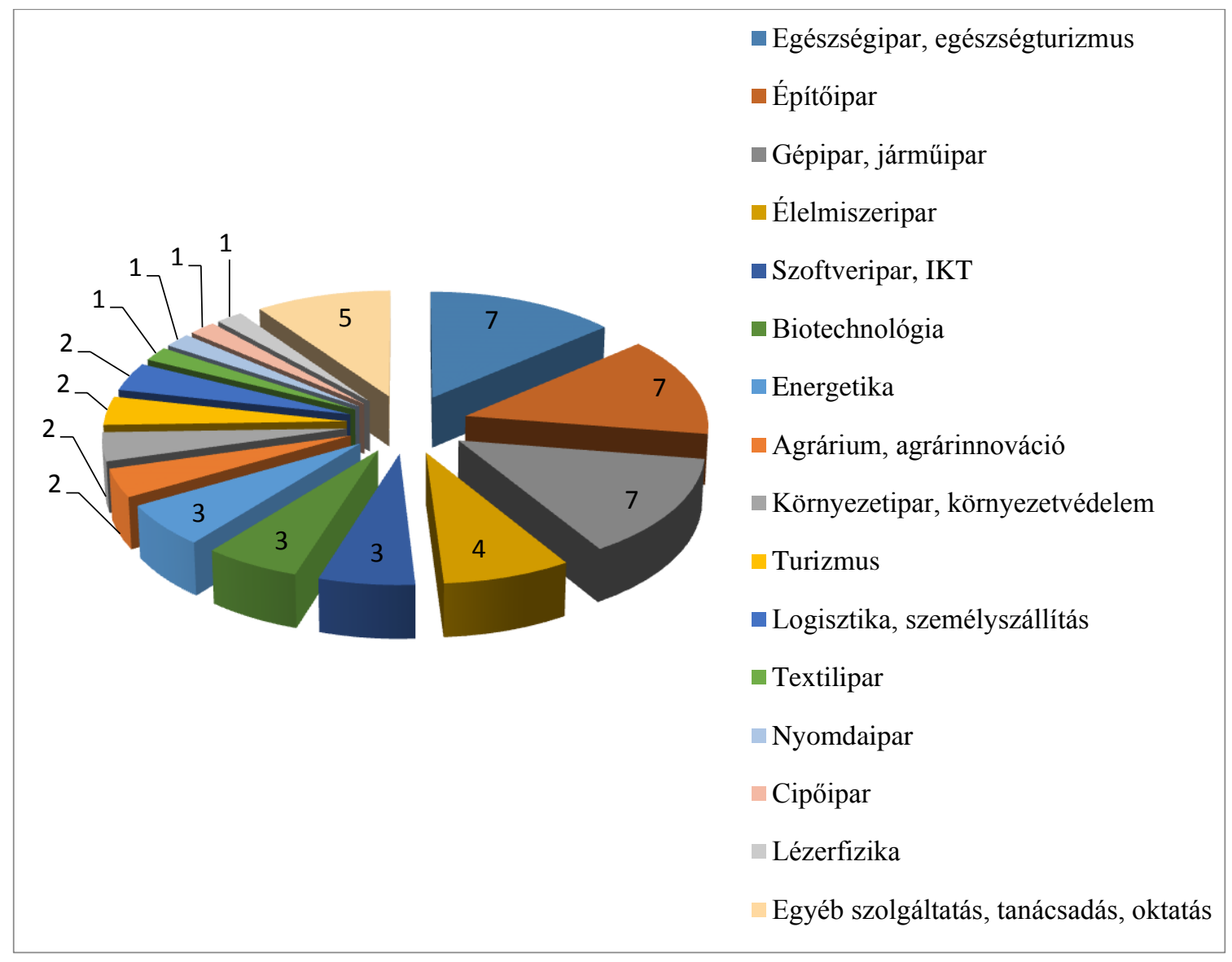

Forrás: Dél-alföldi Regionális Fejlesztési Ügynökség adatbázisa alapján saját szerkesztés

A klaszterek területi elhelyezkedése és koncentrációja is az egyes tudásközpontok kiemelkedő szerepét mutatja. A legtöbb klaszter szegedi székhellyel alakult, de Szeged mellett Kecskemét és Békéscsaba is egyfajta klaszteres csomósodási központnak számít. Ha összehasonlítjuk a klaszterek számát és elhelyezkedését a klaszter székhelye alapján kistérségenként 2010-ben és 2015-ben (13. ábra), akkor láthatjuk, hogy míg 2010-ben 29 klaszter müködött a régióban, addig 2015-re ez a szám elérte az 51-et. A térbeli megoszlás változását tekintve néhány újabb kistérségekben, városban jelentek meg klaszterek és 2015-re megkétszereződött a Szegedhez köthető hálózatok száma. 


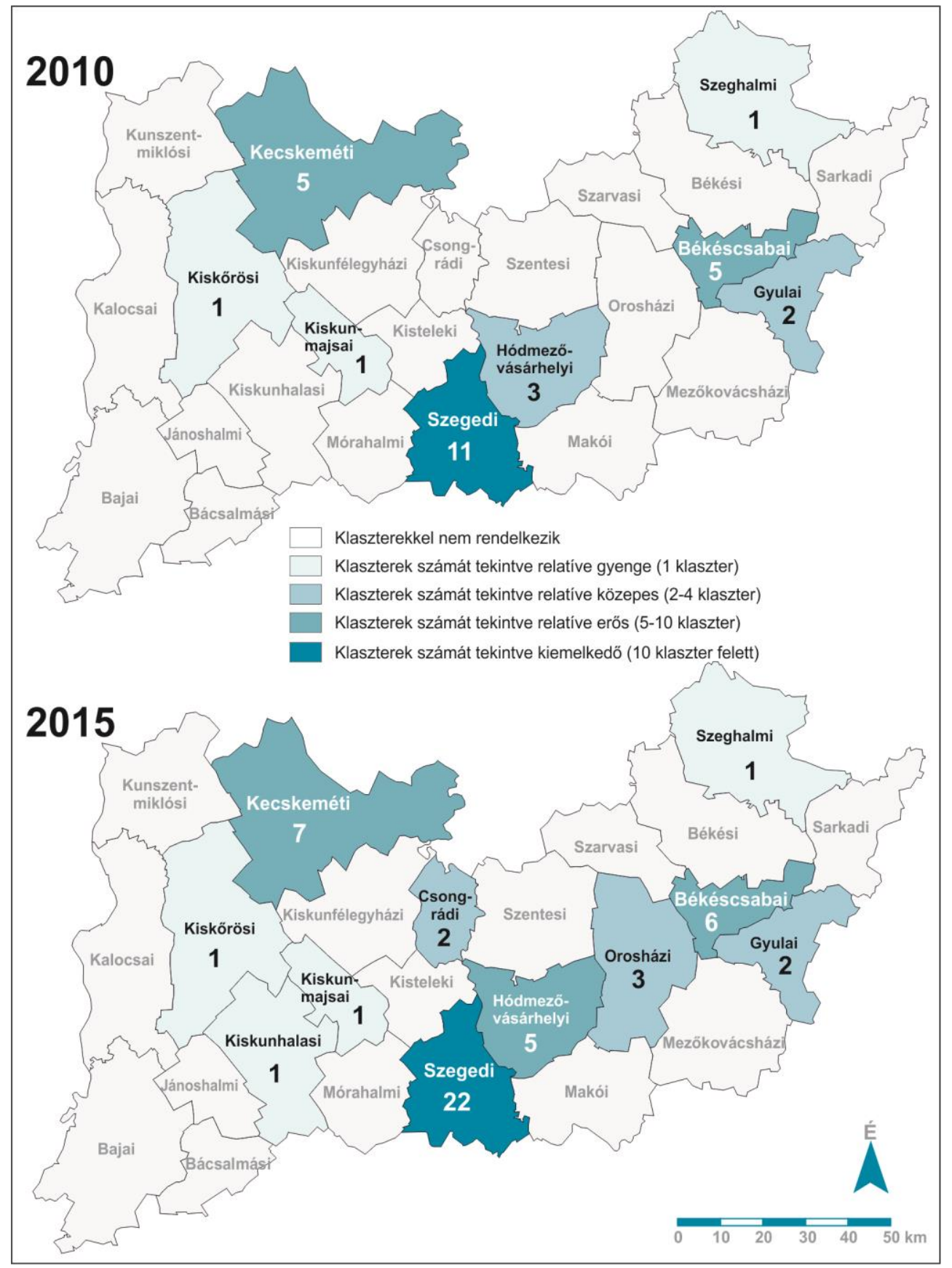

Forrás: Dél-alföldi Regionális Fejlesztési Ügynökség adatbázisa alapján saját szerkesztés

A régióban müködő klaszterek közül 2007-2013 között az alábbi 9 nyerte el az Akkreditált Innovációs Klaszter címet.

1. AIPA Klaszter

2. ArchEnerg Nemzetközi Megújuló Energetikai és Építőipari Innovációs Klaszter

3. Építőipari Kutatási, Innovációs és Technológia-Transzfer Klaszter

4. Goodwill Biotechnológiai Klaszter

5. Hírös Beszállítói Klaszter

6. MIÉNK Klaszter

7. Sárrét Metál Klaszter

8. Szoftveripari Innovációs Pólus Klaszter

9. 3P Müanyagipari, Csomagolástechnikai, Nyomdaipari Klaszter 
Az 5. táblázat a 2007-2013-as programozási időszakban a Dél-alföldi Régióban létrejött Akkreditált Innovációs Klaszterek részletes adatait mutatja be. Az adatok anonimitása érdekében a klaszterek sorszáma nem egyezik meg a fenti felsorolásban szereplő sorszámukkal. A 9 Akkreditált Innovációs Klaszter összesen 342 taggal rendelkezett és a klaszterek átlagos összetételét tekintve a tagok $86 \%$-a kis-és középvállalkozás. Minden klaszterben részt vesz nagyvállalat $(9 \%)$ és 2 akkreditált klaszter kivételével az összes klaszterben megtalálhatóak különböző felsőoktatási intézmények, egyéb kutatóintézetek, önkormányzatok (a tagok $5 \%$-át képviselve).

A régió akkreditált innovációs klasztereinek 2013.évi értékesítés nettó árbevétele $852 \mathrm{Mrd} \mathrm{Ft}$ volt, melynek 34\%-át kis-és középvállalkozások termelték. A lehetséges külpiacra lépés szempontjából fontos mutató az export értékesítés nettó árbevétele, amely a vizsgált klaszterek esetében összesen 287 Mrd Ft volt. A régió akkreditált klaszterei összesen 25331 föt foglalkoztatnak, melyből 2163 felsőfokú végzettségü. A $\mathrm{K}+\mathrm{F}+\mathrm{I}$ teljesítmény mérésére szolgáló mutatók közül láthatjuk, hogy közel 200 Mrd Ft azon vállalkozások árbevétele, akik $\mathrm{K}+\mathrm{F}$ adókedvezményt vettek igénybe 2013-ban és a klaszterek összesen 157 iparjogvédelmi oltalommal rendelkeztek, valamint 45 fö $\mathrm{PhD}$ fokozattal rendelkező személyt foglalkoztattak.

Az együttmüködés és közös kutatás-fejlesztés sikerességének fontos mutatója az elnyert innovációs támogatások nagysága. A régióban müködő akkreditált klaszterek, illetve azok tagjai $197 \mathrm{~K}+\mathrm{F}$ pályázatban vettek részt és összesen 28 Mrd Ft-nyi támogatást nyertek el a Gazdaságfejlesztési és Innovációs Operatív Program $\mathrm{K}+\mathrm{F}+\mathrm{I}$ pályázatain, amely az összes akkreditált klasztertag által lehívott forrás közel 24\%-a (NGM GFP HÁT NEMZETKÖZI ÉS KLASZTER OSZTÁLY 2014). 


\section{5. táblázat A Dél-alföldi Régió Akkreditált Innovációs Klasztereinek adatai 2013-ra vonatkozóan}

\begin{tabular}{|c|c|c|c|c|c|c|c|c|c|c|}
\hline & Klaszter-1 & Klaszter-2 & Klaszter-3 & Klaszter-4 & Klaszter-5 & Klaszter-6 & Klaszter-7 & Klaszter-8 & Klaszter-9 & Összesen \\
\hline Tagok száma (db) & 29 & 46 & 33 & 65 & 30 & 36 & 28 & 49 & 26 & 342 \\
\hline KKV tagvállalatok száma (db) & 28 & 40 & 21 & 60 & 28 & 29 & 23 & 45 & 21 & 295 \\
\hline $\begin{array}{l}\text { Mikro- kis-és középvállalkozások } \\
\text { aránya }(\%)\end{array}$ & 97 & 87 & 64 & 92 & 94 & 81 & 82 & 92 & 81 & \\
\hline $\begin{array}{l}\text { Nagyvállalatok vagy KKV-nak nem } \\
\text { minősülő vállalkozások aránya (\%) }\end{array}$ & 3 & 13 & 18 & 6 & 3 & 11 & 7 & 4 & 15 & \\
\hline $\begin{array}{l}\text { Felsőoktatási intézmények, } \\
\text { kutatóintézet, önkormányzatok, egyéb } \\
\text { tagok aránya (\%) }\end{array}$ & 0 & 0 & 18 & 2 & 3 & 8 & 11 & 4 & 4 & \\
\hline Személyi jell. ráford. 2013 (e Ft) & 4020568 & 11375933 & 17740760 & 39160634 & 4236040 & 3496804 & 3311298 & 7990242 & 20280404 & 111612683 \\
\hline Stat. létsz. 2013 (fö) & 1115 & 2565 & 3081 & 9248 & 1356 & 1239 & 805 & 1595 & 4328 & 25331 \\
\hline Értékesítés nettó árbevétele 2013 (e Ft) & 38363129 & $\begin{array}{r}154905 \\
866 \\
\end{array}$ & $\begin{array}{r}126652 \\
966 \\
\end{array}$ & $\begin{array}{r}259387 \\
038 \\
\end{array}$ & 27722071 & 61757095 & 18884077 & 31860986 & $\begin{array}{r}132749 \\
919 \\
\end{array}$ & 852283148 \\
\hline KKV-k árbevétele 2013 (e Ft) & 17090752 & 30324772 & 25596856 & $\begin{array}{r}121865 \\
400\end{array}$ & 17757573 & 17299463 & 7191215 & 31548925 & 23715744 & 292390701 \\
\hline $\begin{array}{l}\text { Export értékesítésböl származó bevétel } \\
2013 \text { (e Ft) }\end{array}$ & 17582620 & 22168547 & 72546320 & 33969778 & 16017133 & 4393785 & 946030 & 5841562 & $\begin{array}{r}113532 \\
687\end{array}$ & 286998462 \\
\hline $\begin{array}{l}\text { KKV-k export értékesítésböl származó } \\
\text { bevétele } 2013 \text { (e Ft) }\end{array}$ & 212095 & 3566640 & 1320108 & 23635262 & 9123864 & 1855910 & 576078 & 5841562 & 10955707 & 57087226 \\
\hline Közös megjelenések száma (db) & 19 & 13 & 15 & 30 & 13 & 6 & 11 & 43 & 11 & 161 \\
\hline $\begin{array}{l}\mathrm{K}+\mathrm{F} \text { adókedvezményt igénybe vett } \\
\text { vállalkozások árbevétele }(\mathrm{e} \mathrm{Ft})\end{array}$ & 21272377 & 0 & 53229536 & 995378 & 9964498 & 43226254 & 16203787 & 14641282 & 40311913 & 199845025 \\
\hline Felsőfokú végzettségủek száma (db) & 102 & 344 & 307 & 334 & 65 & 184 & 104 & 353 & 370 & 2163 \\
\hline PhD-val rendelkezök száma (db) & 1 & 0 & 11 & 4 & 0 & 4 & 11 & 12 & 2 & 45 \\
\hline Iparjogvédelmi oltalmak száma (db) & 56 & 5 & 14 & 6 & 6 & 29 & 16 & 25 & 0 & 157 \\
\hline $\mathrm{K}+\mathrm{F}$ pályázatok száma $(\mathrm{db})$ & 3 & 5 & 20 & 48 & 8 & 10 & 23 & 72 & 8 & 197 \\
\hline
\end{tabular}

Forrás: PM GFP HÁT Nemzetközi és Klaszter Osztály adatbázisa alapján saját szerkesztés 
A 2007-2013-as programozási időszak lezárása után körülbelül két évig nem állt rendelkezésre semmilyen pályázati forrás a klaszterek támogatására vonatkozóan, így ebben az időszakban számos klaszter felfüggesztette a tevékenységét. Különösen igaz ez az induló fázisban megmaradt kezdeményezésekre, hiszen ezeknek nagyon nagy százaléka nem jutott el az akkreditációs fázisig. A fejlődő klaszterek között is elindult egyfajta koncentrálódási folyamat és szakmai és méretgazdaságossági szempontok alapján több klaszterközi együttmüködés vagy akár klaszter-összeolvadás ment végbe. A fenti folyamatok eredményeként mára kevesebb, de sokkal koncentráltabb és céltudatosabb klaszter müködik a régióban. Az 51 induló klaszterből 2013 végéig 9 tudott eljutni az akkreditációs fázisig, majd az akkreditált klaszterek között is volt egyfajta lemorzsolódás, továbbá volt egy összeolvadás is és ennek eredményeként 2018-ban 5 db klaszter rendelkezik akkreditációval a régióban. Ezen kívül természetesen müködik még néhány olyan fejlett klaszter, amely bizonyos okból kifolyólag nem indult az akkreditációs címpályázaton, viszont a klaszteres tevékenységét aktívan folytatja. Az akkreditált klaszterek taglétszámára és árbevételére vonatkozó adatokat az 6 . táblázat mutatja be.

\section{6. táblázat A Dél-alföldi Régió Akkreditált Innovációs Klasztereinek adatai 2018-ban}

\begin{tabular}{|l|c|c|c|c|}
\hline \multicolumn{1}{|c|}{ Klaszter neve } & $\begin{array}{c}\text { Tagok } \\
\text { száma (db) }\end{array}$ & $\begin{array}{c}\text { Tag- } \\
\text { vállalatok } \\
\text { száma (db) }\end{array}$ & $\begin{array}{c}\text { Nettó } \\
\text { árbevétel } \\
\text { (Mrd Ft) }\end{array}$ & $\begin{array}{c}\text { Export } \\
\text { bevétel } \\
\text { (Mrd Ft) }\end{array}$ \\
\hline AI3PA SMART Klaszter & 51 & 48 & 198,3 & 91,53 \\
\hline $\begin{array}{l}\text { Archenerg Nemzetközi Megújuló Energetikai és } \\
\text { Építöipari Innovációs Klaszter }\end{array}$ & 79 & 78 & 193,6 & 31,71 \\
\hline Hírös Beszállítói Klaszter & 31 & 30 & 143,25 & 111,14 \\
\hline Sárrét Metál Klaszter & 29 & 28 & 126,76 & 18,58 \\
\hline Szoftveripari Innovációs Pólus Klaszter & 37 & 35 & 29,68 & 6,97 \\
\hline \multicolumn{1}{|c|}{ Összesen } & $\mathbf{2 2 7}$ & $\mathbf{2 1 9}$ & $\mathbf{6 9 1 , 5 9}$ & $\mathbf{2 5 9 , 9 3}$ \\
\hline
\end{tabular}

Forrás: PM GFP HÁT Nemzetközi és Klaszter Osztály adatbázisa alapján saját szerkesztés

Összességében ugyan 2013 és 2018 között 9-ről 5-re csökkent az akkreditált klaszterek száma a régióban, az országos tendenciához hasonlóan a klaszterek létszámadatai és gazdasági adatai azonban arányaiban javultak. Az export értékesítés árbevétele szinte alig csökkent a 2013-as értékhez képest és az árbevétel adatok sem arányosan kisebbek a 2013-as adatokhoz viszonyítva, amely egyrészről azt mutatja, hogy a régió innovatív klaszterei erösödtek és szépen lassan elkezdtek növekedni az elmúlt időszakban és ugyan a számuk csökkent, de inkább a magas innovációs és export teljesítménnyel rendelkező együttmüködések maradtak fent. Ezek a klaszterek már jó eséllyel hosszú távon is fent tudják tartani a tevékenységüket és a klaszterfejlesztési politika elvárásainak megfelelő országos szintü csúcsklaszterekké tudnak válni. 


\section{A DÉL-ALFÖLDI RÉGIÓ KLASZTEREINEK ELEMZÉSE}

\subsection{Az elemzés háttere}

A klaszterekkel kapcsolatos kvalitatív kutatásom során azt próbáltam vizsgálni, hogy a Délalföldi Régióban végbement klaszteresedési folyamatok mennyiben tekinthetőek sikeresnek és milyen problémák, akadályozó tényezők merültek fel a klaszterek müködése során. Ahogyan az előző fejezet is bemutattam a Dél-alföldi Régióban az elmúlt évek támogatásainak köszönhetően kellően nagy számban és változatos területeken jöttek létre azon klaszterek, amelyek magukban tömörítik a régió adott iparágainak legfontosabb gazdasági és kutatási szereplőit. Kérdés, hogy eredményesnek tekinthető-e ez az intenzív klaszteresedési folyamat és a régióban létrejött klaszterek rendelkeznek-e a sikeres müködéshez szükséges feltételekkel és hosszútávon meghatározó szereplöivé válhatnak a régió gazdaságfejlesztésének.

A szakirodalom elemzése alapján a sikeresség 4 dimenzióját határoztam meg.

1. Először azt vizsgáltam, hogy a sikeres müködéshez szükséges alapfeltételek rendelkezésre állnak-e a vizsgált klasztereknél, tehát, hogy megfelelő összetételü és müködésü klaszterek jöttek-e létre a régióban, amelyekre a későbbi fejlesztési folyamatokat építeni lehet. Az irodalmi áttekintés alapján ugyanis beigazolódott, hogy a sikeres müködés mögött azonosított kulcstényezők között is van néhány olyan alapvető fontosságú, amelyek megléte szinte minden klaszter esetében szükséges. Ilyen alapfeltételek a földrajzi koncentráció és specializáció, a megfelelő klaszterméret és összetétel, a tagok közötti együttmüködési dinamika és kölcsönös bizalom, a közös szakmai háttér és célok, valamint a professzionális menedzsment szervezet.

2. Az alapfeltételek megléte után a klaszterek által nyújtott előnyöket és hozzáadott értéket vizsgáltam, hiszen a klasztereknek olyan értéket és szolgáltatásokat kell közvetíteniük a tagjaik számára, amelyek hosszú távon biztosítják a szereplők elégedettségét és a klaszter, mint együttmüködési forma müködöképességét. Mivel a klaszterek által nyújtott elönyöket a klasztermenedzsment szervezetek számos tevékenységgel és célzott szolgáltatásokkal igyekeznek erösíteni, a klaszteres elönyök vizsgálatakor a klasztermenedzsment szervezetek szolgáltatásait is részletes elemzés alá vettem.

3. A klaszteren belüli innovációs tevékenységek minősége, meghatározhatja a klaszter egészének sikerességét, továbbá a klaszterek egy adott térség innovációs teljesítményének szempontjából is kiemelkedö szerepet tölthetnek be, ezért a létrejött klaszterek $\mathrm{K}+\mathrm{F}+\mathrm{I}$ kapcsolatait és tevékenységét is részletesen elemeztem. Megvizsgáltam továbbá, hogy a különböző innovációt ösztönző tényezők mennyiben érvényesülnek a régió klasztereinél.

4. A klaszterek sikeressége szempontjából negyedik tényezőként a klaszterek hosszú távú pénzügyi és szakmai fenntarthatóságát emeltem ki, hiszen hiába alakultak ki a megfelelő együttmüködési formák, ha azokat hosszú távon nem sikerül fenntartani. A hosszú távú stabil müködéshez azonban pénzügyi önállóságra, folyamatos szakmai megújulásra van szükség a klaszterek részéről. 
A kvalitatív elemzésemet a fent megfogalmazott 4 kérdés köré építettem fel az alábbi 14. ábrán látható módszertan szerint.

\section{4. ábra A klaszteresedési folyamatok eredményességének vizsgálatához alkalmazott módszertan a Dél-alföldi Régióban}

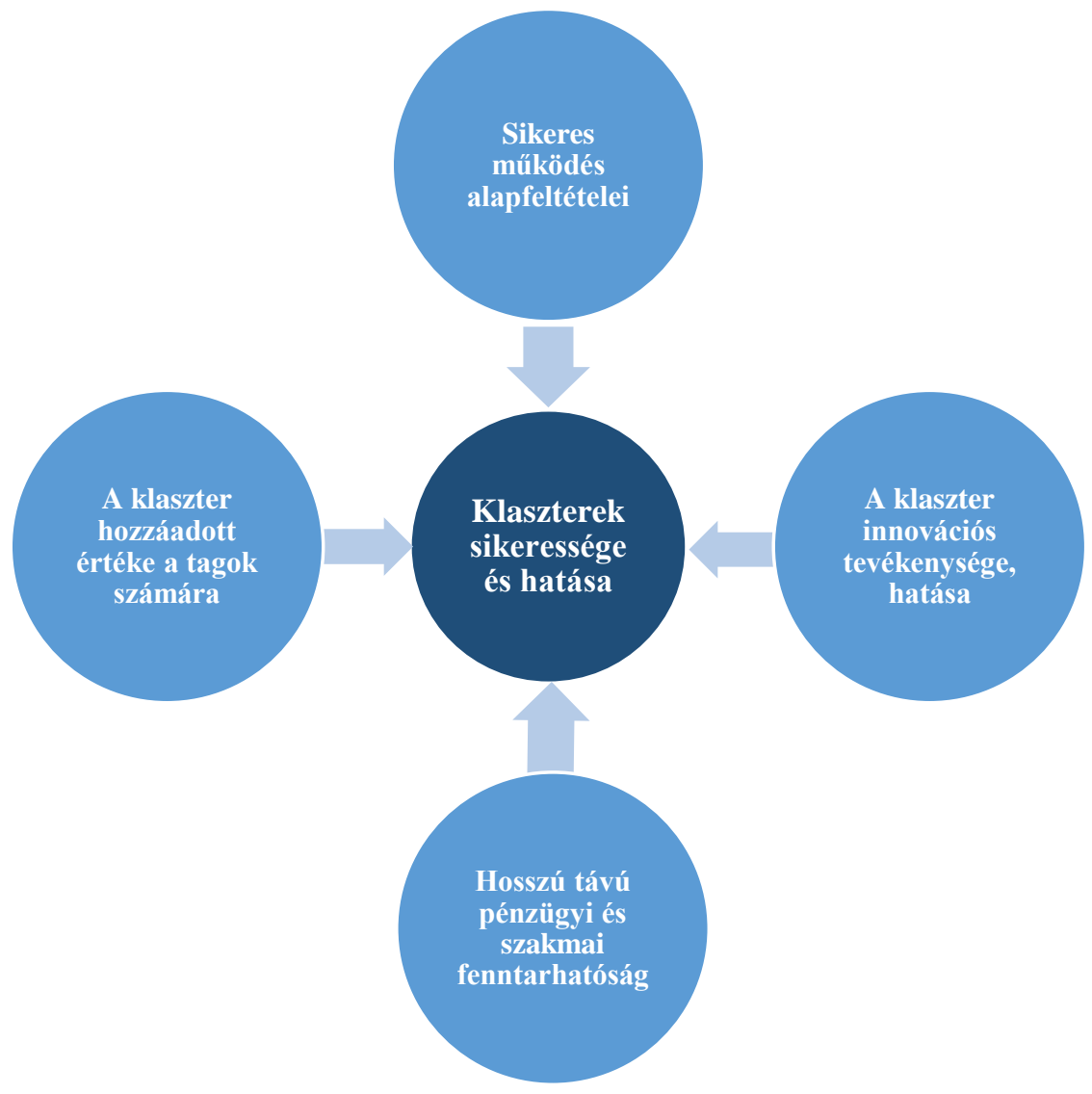

Forrás: Saját szerkesztés

Az elemzésem a régióban múködő 20 klaszter vezetőjével, klasztermenedzserével készített interjúk vizsgálatára épül. Az elemzésbe bevont klaszterek listáját az 7. táblázat mutatja be. $\mathrm{Az}$ interjúalanyok nevesítése csak a 3.sz. mellékletben történik meg, azonban az elemzés során 1-20-ig megjelölt interjúalanyokra hivatkozok, de ez a sorrend nem feleltethető meg a táblázatban megadott sorrendnek.

A bevont klaszterek közül az alábbi táblázatban megjelölt 9 rendelkezett akkreditációval az interjúkészítés időpontjában. Mivel ezen klaszterek már átestek egy szigorú minősítési eljáráson, mely alapján fejlett fázisban lévő, magas innovációs hatással rendelkező együttmüködéseknek tekinthetőek, az elemzés néhány releváns kérdésénél külön is megvizsgáltam az akkreditált és a nem akkreditált klaszterek véleményét és kiemeltem az eltérő fejlődési fázisból adódó véleménykülönbségeket. 
7. táblázat Az elemzésbe bevont klaszterek listája

\begin{tabular}{|c|c|c|c|c|}
\hline Sorszám & Klaszter neve & Iparág/szakterület & $\begin{array}{l}\text { Alapítás } \\
\text { éve }\end{array}$ & Akkreditált \\
\hline 1. & $\begin{array}{l}\text { AIPA (Alföldi Regionális } \\
\text { Iparfejlesztési) Klaszter }\end{array}$ & Jármüipar & 2010 & Igen \\
\hline 2. & $\begin{array}{l}\text { Archenerg Regionális Megújuló } \\
\text { Energetikai és Építőipari Klaszter }\end{array}$ & $\begin{array}{l}\text { Energetika, megújuló } \\
\text { energiák, építőipar }\end{array}$ & 2007 & Igen \\
\hline 3. & $\begin{array}{l}\text { Biotechnológiai és Pharmakológiai } \\
\text { Innovációs Klaszter }\end{array}$ & Biotechnológia & 2011 & Nem \\
\hline 4. & $\begin{array}{c}\text { Dél-Alföldi Regionális } \\
\text { Élelmiszerlánc-biztonsági Klaszter }\end{array}$ & $\begin{array}{l}\text { Egészségturizmus, } \\
\text { Gyógyturizmus }\end{array}$ & 2005 & Nem \\
\hline 5. & Dél-Alföldi Termál Klaszter & Élelmiszeripar & 2008 & Nem \\
\hline 6. & $\begin{array}{l}\text { Építöipari Kutatási Innovációs és } \\
\text { Technológia Transzfer Klaszter }\end{array}$ & Építőipar & 2011 & Igen \\
\hline 7. & Goodwill Biotechnológia Klaszter & $\begin{array}{l}\text { Biotechnológia, } \\
\text { gyógyszeripar }\end{array}$ & 2007 & Igen \\
\hline 8. & $\begin{array}{c}\text { Havaria Környezet- és } \\
\text { Egészségtechnológiai Klaszter }\end{array}$ & $\begin{array}{c}\text { Agrárium, élelmiszeripar, } \\
\text { megújuló energiák }\end{array}$ & 2006 & Nem \\
\hline 9. & Hírös Beszállító Klaszter & Gépipar, autóipar & 2008 & Igen \\
\hline 10. & Hód Iparos Klaszter & Gépipar & 2007 & Nem \\
\hline 11. & $\begin{array}{l}\text { Körösvölgyi Környezettechnológiai } \\
\text { Klaszter }\end{array}$ & $\begin{array}{c}\text { Környezetipar, } \\
\text { környezettechnológia }\end{array}$ & 2012 & Nem \\
\hline 12. & Magyar Klinikai Vizsgálati Klaszter & $\begin{array}{l}\text { Egészségipar, } \\
\text { gyógyszeripar }\end{array}$ & 2010 & Nem \\
\hline 13. & $\begin{array}{c}\text { Magyar Innovatív Építőipari Nyílt } \\
\text { Klaszter }\end{array}$ & Építőipar & 2012 & Igen \\
\hline 14. & $\begin{array}{c}\text { Rózsa Dél-alföldi Hungarikum } \\
\text { Klaszter }\end{array}$ & Turizmus, élelmiszeripar & 2005 & Nem \\
\hline 15. & Sárrét Metál Klaszter & Gépipar & 2008 & Igen \\
\hline 16. & STEPP Klaszter & Lézerfizika, fotonika & 2014 & Nem \\
\hline 17. & $\begin{array}{c}\text { Szoftveripari Innovációs Pólus } \\
\text { Klaszter }\end{array}$ & Informatika, szoftveripar & 2007 & Igen \\
\hline 18. & Zsótér Szolgáltató Klaszter & Szolgáltatás, tanácsadás & 2011 & Nem \\
\hline 19. & 3D Kreatív Innovációs Klaszter & Szoftverfejlesztés & 2011 & Nem \\
\hline 20. & $\begin{array}{c}\text { 3P Múanyagipari, } \\
\text { Csomagolástechnikai Nyomdaipari } \\
\text { Klaszter } \\
\end{array}$ & $\begin{array}{c}\text { Müanyagipar, } \\
\text { csomagolástechnika, } \\
\text { nyomdaipar }\end{array}$ & 2006 & Igen \\
\hline
\end{tabular}

Forrás: Saját szerkesztés

Ahogyan a fenti táblázatból is jól látszik a kutatásba bevont klaszterek között szinte minden a régióban kiemelt, megyei területfejlesztési koncepciókban és S3 stratégiában megjelölt iparág, intelligens technológia képviselteti magát. Területi eloszlásukat tekintve nagyjából tükrözik a Dél-alföldi Régióban létrejött klaszterek területi sajátosságait (15. ábra), miszerint a legtöbb megkérdezett klaszter Szegeden müködik, de emellett több klaszterrel képviselteti magát Kecskemét, Hódmezővásárhely és Gyula is. 


\section{5. ábra A megkérdezett klasztere száma kistérségenként}

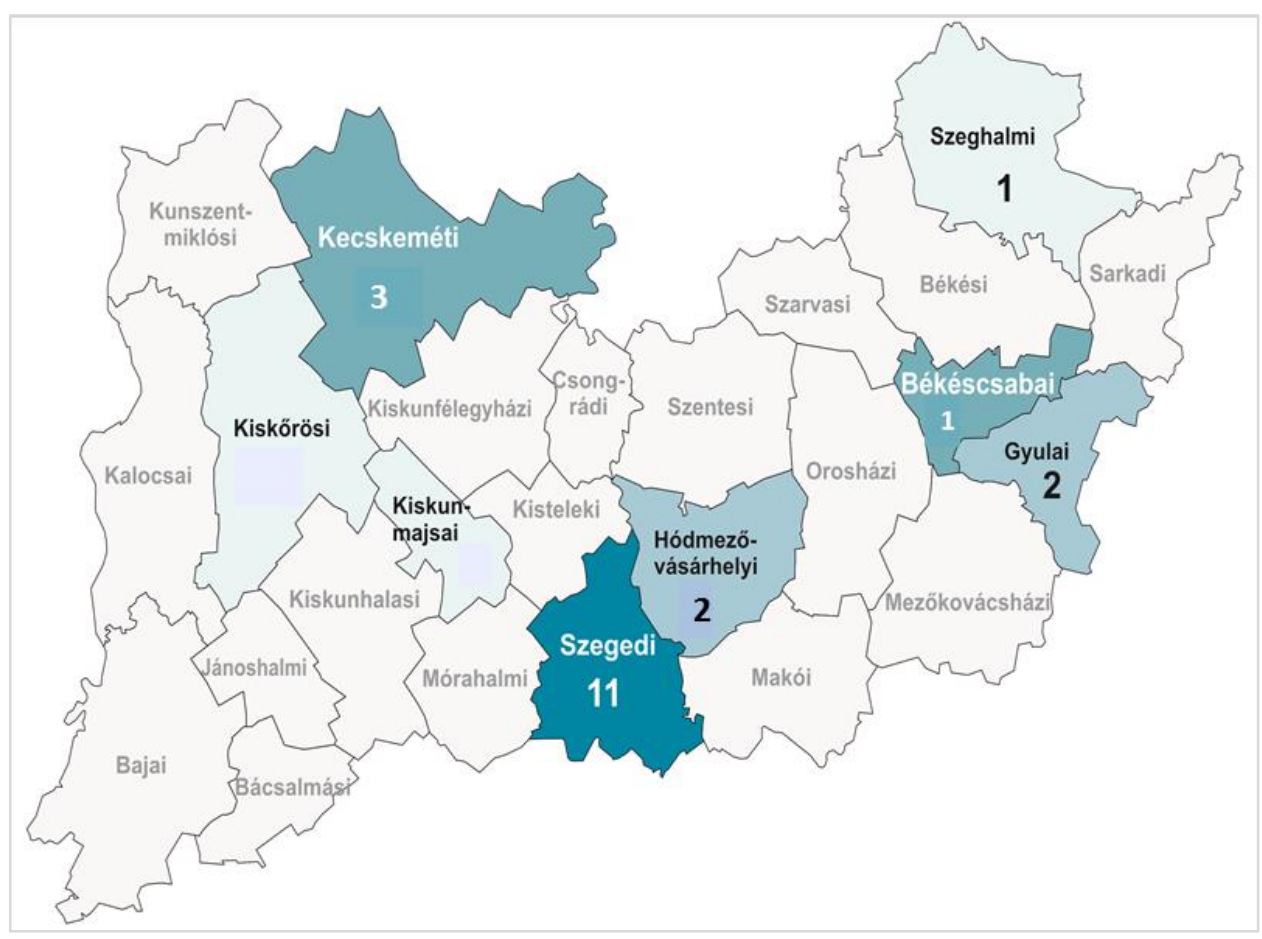

Forrás: Saját szerkesztés

Az elemzés néhány kérdésénél összehasonlítási céllal alapul vettem a 2010-ben a régióban müködő 17 klaszter vezetőjével a PACCLE Magyarország-Szerbia Határon Átnyúló Együttmüködési Projekt keretében készített interjúk eredményeit is. A 2010-es elemzésben szereplö klaszterek listáját a 8 . táblázat mutatja:

\section{8. táblázat A 2010-ben készült elemzésbe bevont klaszterek listája}

\begin{tabular}{|c|c|}
\hline & A 2010-es elemzésbe bevont klaszterek listája \\
\hline 1. & AIPA Klaszter \\
\hline 2. & Archenerg Klaszter \\
\hline 3. & Dél- alföldi Biomassza Hasznosítási Klaszter \\
\hline 4. & Dél-alföldi Fenntartható Fejlödés Szolgáltató Klaszter \\
\hline 5. & Dél-alföldi Innovációs és Tanácsadó Klaszter \\
\hline 6. & Dél-alföldi Közlekedésfejlesztési Klaszter \\
\hline 7. & Dél-alföldi Regionális Építöipari és Innovációs klaszter \\
\hline 8. & Dél-alföldi Regionális Textilipari Klaszter \\
\hline 9. & Dél-alföldi Termálenergetikai Klaszter \\
\hline 10. & Dél-alföldi Zöld Gépipari Technológia-fejlesztési Klaszter \\
\hline 11. & Építőipari-technológia Fejlesztési Klaszter \\
\hline 12. & Goodwill Biotechnológia Klaszter \\
\hline 13. & Havaria Környezet- és Egészségtechnológiai Klaszter \\
\hline 14. & Hírös Beszállító Klaszter \\
\hline 15. & Hód Iparos Klaszter \\
\hline 16. & Szoftveripari Innovációs Pólus Klaszter \\
\hline 17. & 3P Müanyagipari, Csomagolástechnikai Nyomdaipari Klaszter \\
\hline
\end{tabular}

Forrás: saját szerkesztés 
Az alábbiakban összefoglalom a kvalitatív kutatásom legfontosabb eredményeit. Az egyes részeknél, ahol lehetőség nyílik rá, kiemeltem azon elemeket, amelyeket legtöbben említenek (ismétlődő motívumokat keresve), majd a válaszok alapján a kérdéseknek megfelelöen rendszerezem és szintetizálom a legfontosabb eredményeket.

\subsection{A klaszterek létrejöttének háttere, a klaszterek sikerkritériumai}

A klaszterek sikeres müködéséhez biztos alapok szükségesek. Van néhány olyan alapfeltétel, amelyek megléte kiemelten fontos a hosszú távú eredményesség szempontjából, így a Délalföldi Régióban létrejött klaszterek esetében is megvizsgáltam ezen tényezők meglétét és erősségét. Ilyen kulcsfontosságú tényezőként azonosíthatóak a földrajzi koncentráció és specializáció, de ide tartozik még a megfelelő méret és változatos összetétel, a tagok közötti együttműködési dinamika és kölcsönös bizalom kialakulása, a közös szakmai háttér és célok és az ezt támogató professzionális menedzsment megléte is (ANDERSSON, T. et al. 2004, IzSAK, K. et al. 2016, KeTELS, C. 2017, HoRVÁTH, M. et al. 2013)

Az interjúk során megkérdezett klaszterek nagy része 2007 után, jellemzően a Pólus Program és az azt követő többlépcsős klaszter támogatási rendszer forrásainak köszönhetően jött létre és erősödött meg. A klaszterek megalakulásának hátterét általában korábbi együttmüködések, partneri kapcsolatok és közös projektek jelentették. Ezeket az együttmüködéseket bővítették ki a pályázati források megjelenésekor a legfontosabb ágazati szereplők bevonásával, a pályázatban meghatározott szakmai és adminisztratív feltételeknek megfelelöen. Az esetek nagy részében a későbbi úgynevezett klaszter gesztor szervezet ösztönözte és végezte a klaszteralapítást és jellemzően később is ezen szervezetek generálták a klaszter szakmai tevékenységeinek és együttmüködéseinek nagy részét. Az alapítás célja tekintetében a következők jelentették a legfőbb motiváló erőt:

- jó együttmüködési tapasztalatok továbbvitele,

- közös szakmai-fejlesztési célok,

- külső piacokon való együttes megjelenés,

- tudás megosztása,

- új technológiák megismerése,

- piacbővítési lehetőségek,

- közös érdekérvényesítés.

A legtöbb klaszternél kezdetben nem voltak konkrét csatlakozási feltételek. A tagjelöltek kiválasztása és bevonása során a legfontosabb szempont a klaszter céljaihoz és tevékenységeihez való illeszkedésen, a stabil piaci háttéren és a megfelelö szakmai tapasztalaton túl, a megbízhatóság volt. Ennek megfelelően gyakran valósult meg a személyes ajánláson alapuló klaszterszervezés. Minden gesztor szervezet igyekezett a legjelentősebb piaci szereplők bevonására, majd később, a támogatási források megszerzésének érdekében, a különböző pályázati és akkreditációs elvárásoknak megfelelően bővítették a klasztert, szem előtt tartva például a kis- és középvállalkozások arányát és az árbevételre vonatkozó feltételeket is.

A klaszterek sikeressége szempontjából fontos a megfelelő vállalati összetétel és létszám, továbbá, hogy a klaszter tagjai önmagukban is piacképes termékeket, szolgáltatásokat nyújtsanak. Másrészről lényeges, hogy a klasztertagok közül ne legyen túl sok inaktív, az együttmüködésben részt nem vevő szereplő (ANDERSSON, T. et al. 2004).

A megkérdezett klaszterek taglétszámukat tekintve viszonylag alacsony átlagosan 18 taggal jöttek létre és jelenleg ez a szám eléri a 32 tagot. A tagok között megkülönbözetjük a klasztertagokat és számos klaszter müködésében megjelennek az úgynevezett pártoló tagok. 
Pártoló tagként olyan szervezeteket vesznek fel, akik egyetértenek az adott klaszter céljaival, szervezeti- és múködési szabályaival, stratégiájával, de a tagsággal járó kötelezettségeket valamilyen okból kifolyólag nem tudják, vagy nem akarják teljesíteni.

Természetesen van néhány nagyobb méretü hálózat is, melyek akár 60-80 szervezettel müködnek. A bővülés a legtöbb klaszter esetében egyenletes, lassú bövülés volt, bár több klasztervezető kiemelte, hogy az akkreditációs cím és egyéb gazdaságfejlesztési pályázatok megjelenése nagy lendületet adott és ezek kapcsán jelentősebb belépési hullám volt megfigyelhetö. A kilépési indokok között föként a pályázati források elmaradása vagy a tagdíj fizetésének nehézségei szerepeltek, de ezek aránya nem volt túl jelentős.

A vizsgált klaszterek összetételét tekintve a kis- és középvállalkozások aránya átlagosan $75 \%$ körül mozog, a tagok 5\%-a nagyvállalat, míg 20\%-a egyéb szervezet, föként felsőoktatási intézmény és kutatóintézet. Minden klaszter igyekezett a legfontosabb vállalati és kutatási szereplőket bevonni az együttmüködésbe, így azok többségében részt vesz nagyvállalat vagy multinacionális szervezet, de csak két esetben tölt be meghatározó szerepet, sőt volt, ahol a müködésből és döntéshozatalból adódó nehézségek miatt kiléptették ezeket a szervezeteket és csak pártoló tagként vannak jelen a klaszter életében. Az egyetemek és kutatóintézetek aránya is igen magas $85 \%$ és ez a klaszterek egyharmadánál akár 2-3 intézmény részvételét is jelenti. Kiemelkedő szerepe van a Szegedi Tudományegyetemnek, amely számos együttmüködésben vesz részt, de megjelenik a Kecskeméti Főiskola, a Szent István Egyetem és a Bay Zoltán Kutatóintézet is. Ezen intézmények sem töltenek be domináns szerepet a klaszterek életében, jelentőségük inkább a kutatás-fejlesztési és innovációs projektek esetében meghatározó. A klaszteres együttmüködéseket irányító szervezetek főként az alapító cégek és gesztorszervezetek közül kerülnek ki és jellemzően ők határozzák meg a legfőbb stratégiai irányokat és müködési területeket. Az alapító tagok kiemelt szerepe ellenére a klasztervezetők arról számoltak, be hogy az új belépők is kifejezetten jól megtalálják a szerepüket az együttmüködésben és sokszor motiváltabbak és nagyobb erőfeszítéseket tesznek a kölcsönös elönyök kihasználása érdekében, mint a már meglévő tagok.

A tagok közötti kölcsönös bizalmi viszonynak nagyon fontos szerepe van a klaszterek létrejöttében és a későbbi sikeres együttmüködésekben, hiszen megkönnyíti a kapcsolatok kialakítását, a felek közti kommunikációt és a közös projektek zavartalan lebonyolítását (LANe, C. 1998, ANDERsson, T. et al. 2004, OleKAlns, M. - SMiTH, P. L., 2005, IZSAK, K. et al. 2016), melyet szinte kivétel nélkül minden interjúpartner megerösített. E tekintetben nagy jelentősége van a korábbi kapcsolatoknak (GAMBETTA, D. 1988), hiszen ezek a személyes vagy üzleti ismeretségek nagyban hozzájárulnak a klasztertagok közötti bizalmi viszony kialakulásához és megtartásához.

A klaszter, illetve a klasztermenedzsment szervezetek számára az egyik legfontosabb feladat a tagok közötti együttmüködési képesség fejlesztése és konkrét projektek kezdeményezése. Az érdemi együttmüködés megalapozásához nagyon fontos a bizalmi tőke kialakítása. Az interjúk alanyai kiemelten fontosnak tartották a bizalmi kapcsolatok megteremtését a klaszteren belül, melyre időt és energiát kell szánni, de ez nagyban hozzájárul a közös projektek sikeréhez. Véleményük szerint a klasztertagok közötti bizalmi viszonyt erősíti egyrészről, hogy ezek az együttmüködések a legtöbb esetben a klaszter alapítása előtti időszakra is visszanyúló kapcsolatokra épültek és ezeket bővítették ki a tagok személyes ajánlásai alapján. A 20. interjúalany ezzel kapcsolatban így fogalmazott:

„Nagy szerepe van, az elsö idökben szinte teljesen erre épült és most is erre alapozzuk a kapcsolattartást és a müködést. Erösiteni az egyéb projektben való közös együttmüködéssel szoktuk" (20.) 
A 10. interjúalany kiemelte a bizalom fontosságát a kutatás tevékenységek szempontjából is: „Nagyon magas a szerepe, nyilván a klaszter létrehozása is ilyen bizalmi kapcsolatra épült. Mivel kutatásról van szó ez mindenkinek a legféltettebb kincse. A bizalom kiépitése nagyon fontos. A bizalmatlanságot állítjuk szembe az együttmüködésböl fakadó vonzerövel. Itt a stratégiák összehangolásáról van szó. A klaszter tagvállalatai kutatási területeken vesznek részt, így ezekkel a kényes kérdésekkel tisztában vannak." (10.)

Ha nincs meg a megfelelö bizalmi légkör a tagok között, akkor nem fogják megosztani egymással a tudásukat és az információikat és akkor a klaszter közös céljai érdekében sem tudnak hatékonyan együttmüködni. Az egyik klasztervezetö kiemelte, hogy „,... fontos, hogy ki milyen környezetben szocializálódik, nemzetközi üzleti, egyetemi, vagy akár egyéb”. (14.) Ez az eltérő háttér nehezítő tényezőként jelenik meg a bizalom és a kapcsolati közelség kialakítása, fejlesztése tekintetében.

Azon klaszterek esetében, ahol nem voltak komolyabb elözményei a kooperációnak, így a tagok közötti bizalmi kötelékek még nem alakultak ki, a klasztermenedzsment szervezetek elsősorban a közös rendezvényekkel tudták elömozdítani a szükséges kapcsolatok kialakulását. Az interjúalanyok nagy része kiemelte az egymás megismerését szolgáló események és kezdeményezések jelentőségét. Azoknál a klasztereknél azonban, amelyeknél a tagok nagy része már a klaszter megalakulása előtt is ismerte egymást, illetve valósított meg közös projekteket, a klasztermenedzser legfőbb feladata a tagok igényeit, kompetenciáit ismerve a tudatos és célzott projektgenerálás. Ezen klasztervezetők legnagyobb része inkább a projektgenerálást jelölte meg, mint a bizalom további erősítésének és az együttmüködés serkentésének legfontosabb eszközét. Az akkreditált klaszterek vezetői a teljes mintán belül az átlagosnál fontosabbnak vélték a bizalom szerepét és erősítését, ami valószínü abból adódhat, hogy ezen klaszterek már több olyan kutatás-fejlesztési pályázatot bonyolítottak le közösen, amely nagyobb kockázatot és befektetést jelentett a tagok számára, és amely projektek sikeres megvalósításához nagy szükség volt a partnerek közötti bizalmi tőkére is.

A földrajzi koncentrációt és az ebböl fakadó előnyöket a klaszterek kialakulásának egyik meghatározó tényezőjeként szokták említeni. A közelségnek nagy szerepe van a személyes kapcsolatok ápolásában és a bizalmi viszony kialakításában, viszont az információs és kommunikációs technológiák fejlődésével és a klaszterek globális piacokon való megjelenésével a hangsúly egyre inkább áthelyeződött a földrajzi közelségről a kapcsolati közelség szerepére (BOSCHMA, R. 2005, TORRE, A. - RALLET, A. 2005).

A vizsgált klaszterek földrajzilag koncentráltan müködnek, hiszen a mintában szereplö klaszterek tagjainak átlagosan 70 \%-a müködik a régióban, de a régión kívüli tagokkal is nagyon szoros és jó együttmüködésben dolgoznak. A klasztervezetők véleménye szerint a földrajzi kötöttséget tekintve egy klaszternek inkább rugalmasnak kell lennie, a hosszú távú fejlődés érdekében. A második interjúalany szerint: „Ma már nincs akkora jelentösége a földrajzi kötöttségnek a technika fejlödésével" (2.)

A földrajzi közelségnek inkább a személyes kapcsolatok ápolásánál van nagyobb jelentősége, hiszen azt nagymértékben megkönnyítheti, ha egymáshoz közel müködnek a tagok. Több klasztervezető hasonlóan vélekedett, mint a 11. interjúalany: „A tapasztalatcsere esetében elöny a földrajzi közelség, a személyes találkozások miatt nyilván praktikusabb.” (11.)

A közös szakmai munka és a projektek esetében azonban nincsenek olyan nagy távolságok, amelyek áthidalása problémát okozna, így a klasztervezetök gyakran utaznak a régión kívüli tagjaikhoz és ez nem jelent számukra különösebb terhet. A 4. klasztervezető az alábbiakban fogalmazta meg: 
„..fontos, hogy területileg egymáshoz közel vagyunk, ismerjük egymást. Van szerepe, elönye a földrajzi közelségnek, egyszerüen könnyebb az együttmüködés. Másrészröl viszont a távolságok leküzdhetöek, így nem lehet területileg lekorlátozni egy klasztert.” (4.)

A megkérdezett klaszterek többsége épít a lokális elönyökre, a helyi gazdasági szereplőket, a helyi kutatási intézményeket és néhány esetben még az önkormányzatot is igyekeznek bevonni a klaszter életébe, így ez biztosítja a klaszter beágyazódását az őt körülvevő gazdasági- társadalmi környezetbe. Mindösszesen 3 klaszter nyilatkozott úgy, hogy a helyi kapcsolatok nem túl erősek és a helyi viszonyok nem befolyásolják a müködésüket, mivel tevékenységük földrajzilag független és inkább országos vagy nemzetközi színtéren zajlik. A lokális előnyöknél a legtöbben a helyi felsőoktatási és kutatóintézetekkel való kapcsolatokat emelték ki.

A klaszterek hatékony müködéséhez a klasztertagok által egységesen elfogadott rövid és hosszú távú célokra és közös stratégiára van szükség. Fontos, hogy minden tag megismerje és elfogadja a klaszter közös céljait és azok összhangban álljanak a klasztertagok egyéni törekvéseivel. Emellett lényeges, hogy a klasztertagok minél szélesebb körét sikerüljön bevonni a tervezésbe és a közös projektek megvalósításába egyaránt. A klaszterekben olyan érdekrendszer kialakítása szükséges, ahol a klasztertagok ráfordításai egyensúlyban vannak a klasztertagság révén elérhető előnyökkel. A vizsgált klaszterek vezetői legföbb tevékenységként jellemzően a tagok közötti információáramlást, közös projektek generálását és a piaci versenyben való együttes fellépést nevezték meg.

Az elmúlt években a legtöbb klaszter közös stratégiát és akciótervet dolgozott ki a konkrét együttmüködésekre vonatkozóan, illetve a pályázati támogatásokból több projektet, fejlesztést vagy akár beruházást is valósítottak meg közösen. A vizsgált klaszterek együttmüködéseit bemutató 16. ábra alapján láthatjuk, hogy szinte minden klaszter végzett kompetencia- és igényfelmérést a tagok között, mely a későbbi együttmüködéseket alapozta meg, illetve nagy részük valósított meg közös marketing tevékenységet, amely a klaszter ismertségét segíti elö. A klaszterek szintén nagy arányban (a 20 vizsgált klaszter közül 17) valósítottak meg valamilyen közös projektet, vagy közös piaci megjelenést, viszont a közös beruházásokat, eszközbeszerzéseket tekintve ez az arány már jóval alacsonyabb, hiszen ehhez jelentős saját erőt is kellett biztosítania a tagoknak. A megkérdezett klasztereknek csak fele vett részt valamilyen nemzetközi kooperációban, projektben, viszont szinte minden interjúalany kiemelte, hogy jövőbeni célként szeretné a nemzetközi együttműködések arányát növelni és ebben látják a klaszter jövőbeni fejlődési lehetőségét.

Érdekes eredmény, hogy az előzetes feltételezésem ellenére, miszerint az innovatív, exportorientált, stabil együttmüködési háttérrel rendelkező akkreditált klaszterek valószínúleg több nemzetközi projektben vettek részt, nem igazolódott be. A nemzetközi együttmüködések aránya ugyanis az ö esetükben sem volt kimagasló, tehát ezen a területen még a régió akkreditált klaszterei is további fejlesztésre szorulnak. 


\section{6. ábra A klaszterek közös tevékenységei}

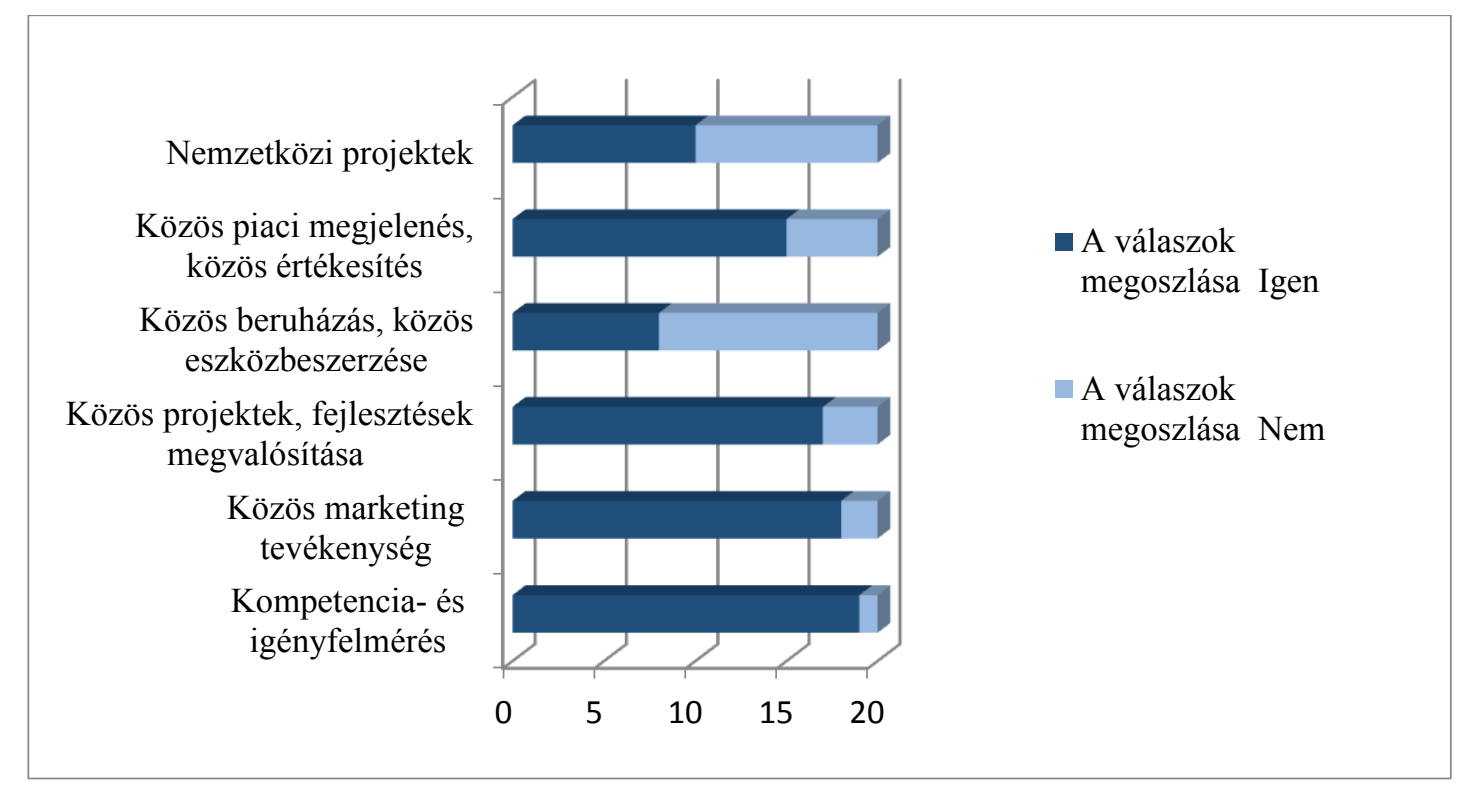

Forrás: Saját szerkesztés

Arra a kérdésre, hogy mit tartanak a klaszter legnagyobb erősségének (17. ábra) a klasztervezetők nagyobb része az erős kis- és középvállalkozó hátteret jelölte meg, míg második helyen 9 interjúpartner szerint a jelentős $\mathrm{K}+\mathrm{F}+\mathrm{I}$ tevékenységek jelentik a legnagyobb vonzerőt a tagok számára. Az erős piacvezető cégek már csak a vizsgált klaszterek egynegyedénél jelentettek igazi erősséget, hiszen sok klaszter a nagyvállalatok bevonása helyett, inkább a kis- és középvállalkozások együttmüködésére koncentrál. A nemzetközi kapcsolatok szerepe csak a klaszterek nagyon kis százalékában jelenik meg, melyre saját elmondásuk szerint is nagyobb hangsúlyt kell fektetniük a klaszteres vezetőknek. Az első két helyen szereplő erős vállalkozó háttér és az egyre fokozódó klaszteren belüli innovációs tevékenység azonban megfelelő alapot jelenthet ezen hálózatok stabil müködéséhez és hosszú távú fejlődéséhez.

\section{7. ábra A Dél-alföldi Régió klasztereinek erőssége}

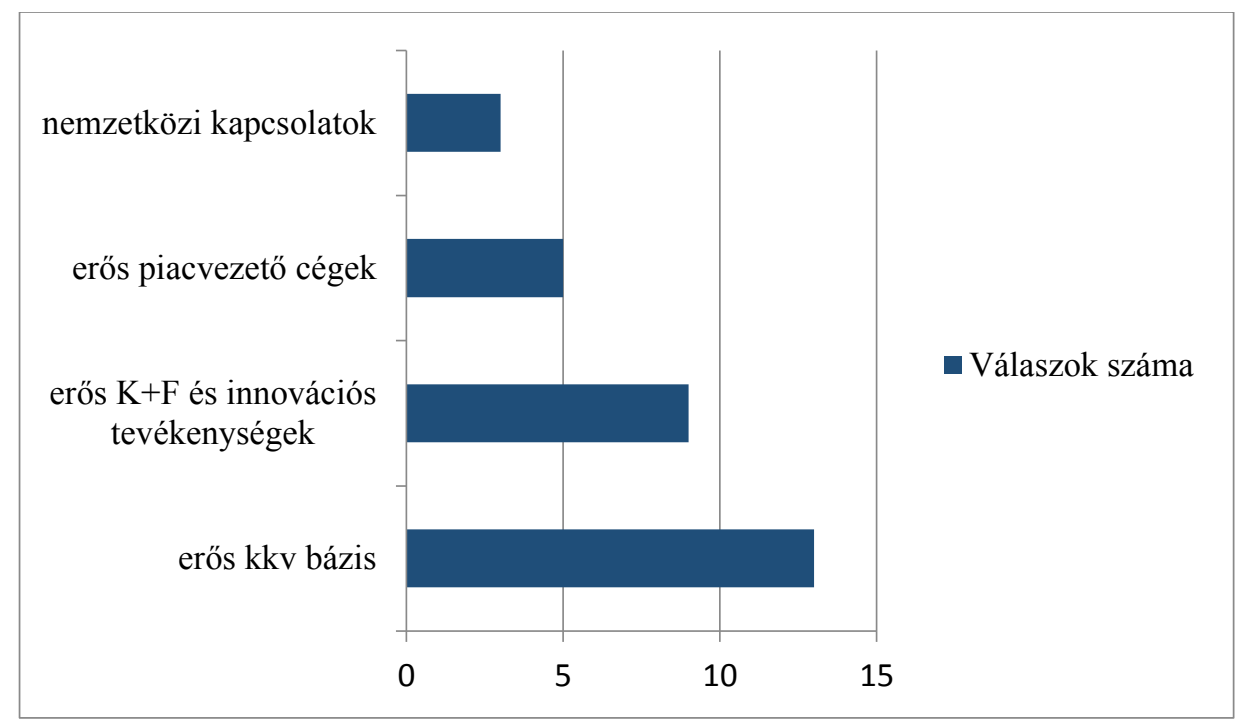

Forrás: Saját szerkesztés 
A klaszterek sikeres müködéséhez elhivatott és professzionális klasztermenedzsmentre és vezetésre van szükség. A klasztermenedzsment szervezet képes összefogni a tagokat, jól ismeri a tevékenységeiket, kompetenciáikat ezáltal hatékonyan tudja képviselni az érdekeiket és elősegíteni az együttmüködést. A klaszter menedzsment szervezet különféle szakmai, menedzsment és adminisztratív szolgáltatásokat nyújt a tagok részére, továbbá ellátja a klaszter képviseletét, valamint elősegíti a klasztertagok által közösen megalkotott stratégia megvalósítását. A menedzsmentnek nagy szerepe van a klaszter finanszírozási rendszerének kialakításában és ezáltal a hosszú távú fenntarthatóság biztosításában (EUROPEAN COMMISsiON 2008, Buhl, C. M. - Köcker, G. M. 2009).

Az elmúlt 10 év induló klasztereket támogató forrásai jellemzően a klasztermenedzsment szervezet felállítását és a klaszter müködési rendszerének kialakítását ösztönözték. Ennek köszönhetően mára már a régióban müködő klaszterek nagy része egy viszonylag egységes keretrendszerben és irányítással, továbbá több éves szakmai és menedzsment tapasztalattal működik. A vizsgált klaszterek vezetését és az együttmüködéssel kapcsolatos teendőket jellemzően 1-3 főből álló klasztermenedzsment szervezet végzi. A klasztermenedzsmentben dolgozók végzettségüket tekintve főként inkább menedzseri, de néhány esetben szakmai végzettséggel rendelkeznek. A klaszter élén jellemzően klaszter elnök vagy klaszter igazgató áll, akinek a munkáját a klasztertagok által választott klaszterbizottság, vagy klasztertanács segíti. A klasztereket érintő legfontosabb döntésekben, a stratégiai irányok meghatározásában a klaszterbizottság vagy a taggyülés dönt. A klaszterek müködését és az együttmüködés alapfeltételeit a klasztermenedzsment szervezet aktív munkája biztosítja. Emellett a tagok közötti megfelelő információáramlást a rendszeresen, jellemzően félévente, vagy negyedévente összehívott taggyülés és a különböző témákra specializálódott munkacsoport ülések biztosítják.

Hipotézis 1. Az elmúlt évek intenzív klaszterfejlesztési támogatásainak köszönhetően a Délalföldi Régió klaszterei rendelkeznek a sikeres müködéshez szükséges alapfeltételekkel.

A Dél-alföldi Régió klaszterei 2007 és 2013 között egy nagyon intenzív fejlődési folyamaton estek át, melynek eredményeként sikerült kialakítaniuk a müködéshez szükséges struktúrát, szervezeti hátteret. Első lépésként bevonták az adott iparág vagy szakterület legjelentősebb szereplöit, főként a régióból, de számos esetben akár azon túlnyúlva is. Meghatározták a közös stratégiájukat és konkrét céljaikat, kijelölték a szakterületüket, specializációjukat, továbbá a szervezeti és müködési szabályaikat. Létrejöttek az együttműködések koordinálásáért felelős klaszter irányító bizottságok és menedzsment szervezetek, melyek elindították az együttmüködést ösztönző legfontosabb tevékenységeiket, szolgáltatásaikat. A pályázati támogatásoknak köszönhetően egyre több közös projektet valósítottak meg és néhány esetben akár klaszteres beruházásokat is végrehajtottak, melyek hozzájárultak az együttmüködés alapvető szabályainak és irányainak lefektetéséhez, továbbá a kölcsönös bizalom megteremtéséhez. A klasztermenedzserek megítélése szerint erös kis-és középvállalkozói hátteret és kutatás-fejlesztési tevékenységeket alakítottak ki. Összességében tehát a régió klasztererei megteremtették az együttmüködés stabil szakmai és adminisztrációs hátterét, amely a sikeres működéshez és fejlődéshez elengedhetetlen feltétel. A sikerességi tényezők közül a kölcsönös bizalom és a konkrét együttműködések területén szükséges még további lépéseket tenniük, annak érdekében, hogy elmélyítsék és egy bizonyos szintig akár önműködővé tegyék a klaszteres tevékenységeket.

A fejezet elején bemutatott sikerességi tényezők vizsgálata alapján igazolást nyert az 1 . hipotézis, mely szerint a Dél-alföldi Régió klaszterei rendelkeznek a sikeres müködéshez szükséges alapfeltételekkel. 


\subsection{A klaszterek hozzáadott értéke, a klaszteren belüli szolgáltatások fejlődése}

A következő részben azokat a kérdéseket emeltem ki, amelyek megmutatják, hogy a régió klaszterei mekkora hozzáadott értéket képviselnek a tagjaik számára, mennyire használják ki a klaszteres együttmüködésekben rejlő előnyöket, és a klasztermenedzsment milyen szolgáltatásokkal igyekszik erősíteni ezeket.

A klaszterek az egymással bizonyos területeken együttmüködő és más területeken versengő vállalkozások, kapcsolódó intézmények, specializált szolgáltatók olyan hálózata, amely egy jól körülhatárolható iparágban vagy szakterületen müködik, és gyakran akár egy teljes termelési értékláncot is képes lefedni (EnRIGHT, M. J. 1996, ScOTT, A. J. 1988, Grosz., A. 2004). A vállalkozások közötti versengés és együttmüködés együttes jelenléte teremti meg a klaszterek fejlődéséhez szükséges belső dinamikát (ANDERSSON, T. et al. 2004).

A Dél-alföldi Régióban megkérdezett klaszterek tagjai fóként egymást kiegészítő tevékenységet végeznek és már a klaszter létrehozása idején célkitüzés volt, hogy a lehető legváltozatosabb tevékenységi körökben müködő tagokat bevonva akár egy teljes értékláncot le tudjanak fedni, ezáltal is növelve az együttmüködésből fakadó előnyöket. Mindössze három klasztervezető nyilatkozott úgy, hogy a tagok inkább versenytársai egymásnak az adott piacon, de a klaszteren belül igyekeznek megtalálni a kooperációs lehetőségeket. Azokban az esetekben, ahol inkább versengő a klaszter belső szerkezete, sokszor gondot jelent, hogy a konkurens megközelítés miatt nehezebben osztják meg egymással az információikat a résztvevők. A második interjúalany az alábbiakban fogalmazta meg ezt a kihívást:

„Inkább versenytársai egymásnak, sokszor ez problémát is jelent, mert emiatt nehezebben tudnak megnyilni. Olyan rendezvényeket próbálunk szervezni, ahol elötérbe kerül az együttgondolkodás, az innováció." (2.)

Egy másik klasztervezető ennél jóval kritikusabban nyilatkozott: „A magyar klasztereknek az az alapvetö betegsége, hogy szük piacon müködö, hasonló területtel, termékkel foglalkozó cégek tömörülése, ami befagyasztja az együttmüködést."(14.)

A klasztervezetök nagy része azonban inkább a 6 . interjúalany válaszához hasonlóan vélekedett:,,Próbáltunk egy olyan szegmenst találni, ami nem a hagyományos szemléletet tükrözi, hanem valamilyen új irányt képvisel. Azóta az élet ezt az irányt visszaigazolta. Vannak a tagok között versengök és egymást kiegészitök is vegyesen, de a klaszter törekszik a teljes értéklánc lefedésére, portfólió épitésére, azonban ehhez idő kell." (6.)

A klaszterek müködése mögött egyértelműen definiálható üzleti érdekek húzódnak meg, mivel minden résztvevő előnyöket realizál a kooperáció révén A klaszter együttmüködésekből származó elönyök igen sokfélék és összetettek. A tagok a térbeli koncentrálódás és együttmüködés révén költségmegtakarítást érhetnek el például a közösen igénybevett erőforrások vagy beszerzések által, gyorsabban és könnyebben jutnak a számukra értékes piaci tudáshoz, információkhoz, továbbá a klasztertagok körében megvalósult közös fejlesztések, projektek is értéket teremthetnek a számukra (PORTER, M.E. 1998, COOKE, P. 2001, ENRIGHT, M. J. 2003, DELGADO, M. ET AL. 2014).

Ahogyan a 18. ábra is mutatja a Dél-alföldi Régióban megkérdezett klasztermenedzserek megítélése alapján a klaszter legnagyobb hozzáadott értéke leginkább a közös $K+F$ projektek generálásában és a pályázati források megszerzésében van. A klasztervezetők több, mint fele úgy érzi, hogy ezen a két területen tudnak a legtöbbet nyújtani a klasztertagok számára. Mindezek mellett heten értékelték úgy, hogy a klaszter jelentősen hozzájárul a tagok közötti tudásmegosztáshoz, a versenyképességük növeléséhez, valamint a nemzetközi együttmüködések kialakításához és a nemzetközi piacok eléréséhez is. Tekintve ezen területek 
kiemelkedő fontosságát a klaszterek jövője és a nemzetközi klaszterfejlesztési irányok szempontjából, ez az arány viszonylag alacsonyak mondható, tehát ezeket a területeket még fejlesztenie szükséges a klaszter vezetőinek. A klasztermenedzsment szolgáltatások fontosságát és hozzáadott értékét csak egy klasztervezető ítélte említésre méltónak, szemben azzal a ténnyel, hogy szinte minden klasztermenedzsment szervezet jelentős energiákat fektet a szolgáltatások kialakításába és bővítésébe. Ez egyrészről természetesen adódhat abból is, hogy a klasztermenedzsment szolgáltatásinak egy része a többi tényező erősítésére irányul, így azt nem tartották fontosnak külön kiemelni az interjúalanyok. Másrészről viszont jelentheti azt is, hogy a szolgáltatásokat csak egyfajta addicionális előnynek tekintik a klasztermenedzserek és a klaszter igazi hozzáadott értékét nem ebben látják.

A pályázati források kapcsán a 2007-2013-as időszakban megkérdőjelezhetetlen a klaszterek forrásszerzési képességeinek jelentősége, hiszen ekkor jelentős mennyiségü pályázati támogatás állt rendelkezésre, amely komoly vonzerőt jelentett a klasztertagok számára. Felmerül azonban a kérdés, hogy a pályázati pénzek csökkenésével, ezen igen fontosnak értékelt terület nélkül is elég vonzóak lesznek-e a klaszterek ahhoz, hogy megtartsák a klasztertagjaikat, vagy akár még bővüljenek is. Valószínűleg a fókuszterületeket tudatosan át kell majd helyezni a jelenleg még kevésbé érvényesülő nemzetközi projektekre és tudásmegosztási tevékenységekre.

\section{8. ábra A klaszter hozzáadott értéke a tagjai számára}

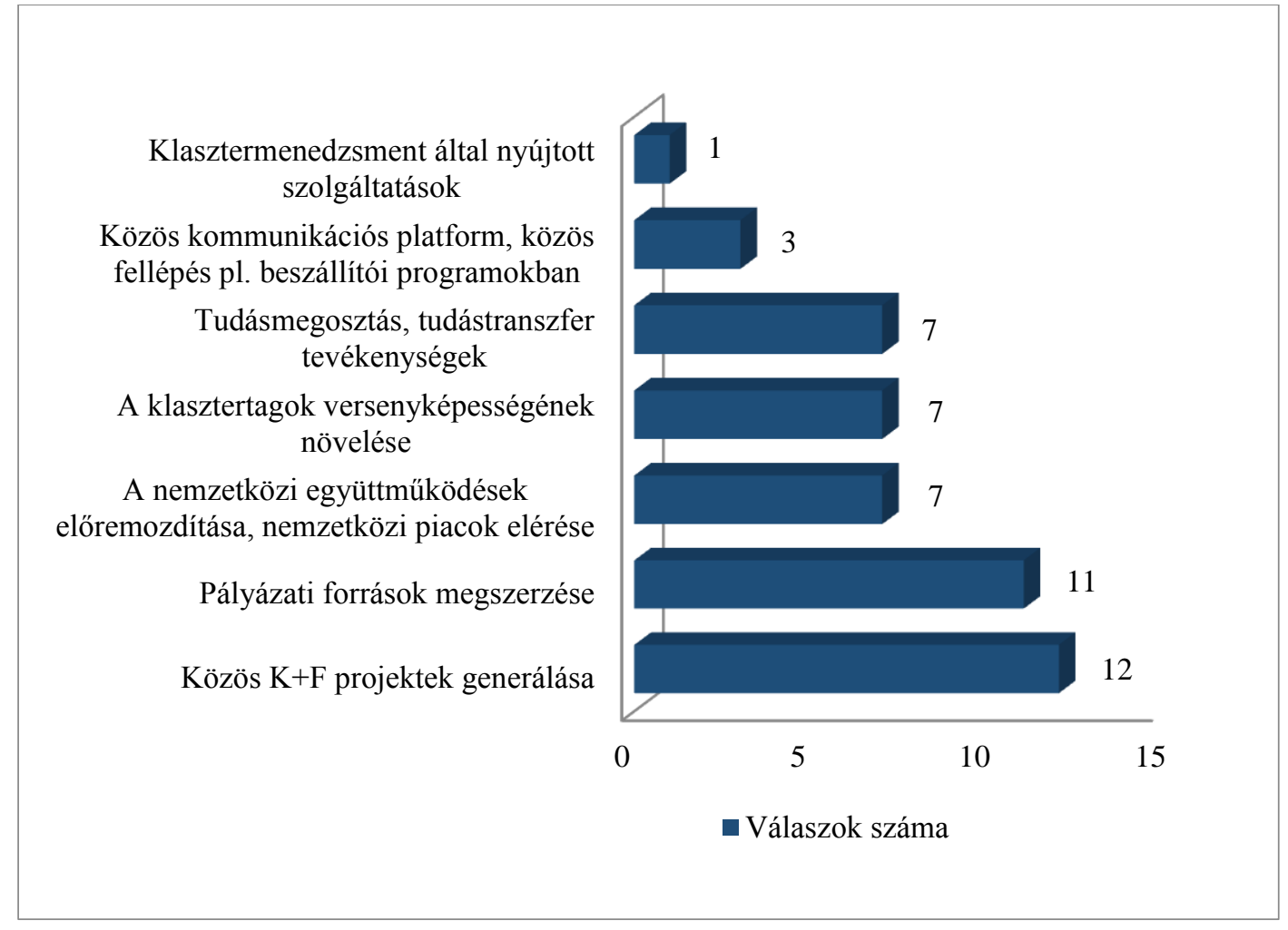

Forrás: Saját szerkesztés

A klasztermenedzsment szervezetek számos tevékenyéggel és célzott szolgáltatással járulnak hozzá a klaszteres együttmüködések révén elérhető előnyök fokozásához. A klasztertagok számára nyújtott speciális szolgáltatások kulcsfontosságú eszközei a klaszteres együttmüködések ösztönzésének és megfelelő kombinációjuk jó hatással lehet a klaszterben múködő szervezetek teljesítményére, ezáltal a klaszter sikerességére (NERGER, M. et al. 2014., Christensen, T. et al. 2012, Ketels, C. et al. 2013).

A vizsgálatba bevont klasztermenedzsment szervezetek folyamatosan fejlesztik a klasztertagok számára nyújtott szolgáltatásaikat a klasztertagok igényei és a változó piaci 
környezet tükrében. Összehasonlítva a 2010-es válaszokkal, látható, hogy a klaszterek már 2010-ben is igen széles körü, változatos szolgáltatásokat nyújtottak a szervezési és kommunikációs feladatoktól kezdve, a különböző kapcsolatépítési, tanácsadási és forrásszerzési tevékenységekig. Projektgenerálási és konferenciaszervezési feladatokat, továbbá a pályázati tanácsadás és a közös holnap kialakítására, üzemeltetésére vonatkozó tevékenységeket a klaszterszervezetek nagy többsége már 2010-ben is biztosította a tagjai számára.A 2010-es évhez képest főként a belső és külső kommunikációs tevékenységek, a szakmai és benchmarking klubok, továbbképzö programok szervezése, valamint a forrásszerzési lehetőségek feltárása terén történt pozitív előrelépés, hiszen egyre több klaszter nyújtotta ezeket a szolgáltatásokat a tagjai számára. Teljesen új tevékenységként jelent meg a külföldi kapcsolatépítés, mely az elmúlt években egyre inkább előtérbe került a klaszterek életében. A tartós versenyelőny megszerzése, illetve megtartása érdekében ugyanis a klasztereknek is eröteljesen kell koncentrálniuk a különböző exportpiacokra, valamint meg kell ismerniük a nemzetközi klaszterek sikeres müködési modelljeit. A klasztertagok számára nyújtott szolgáltatások körét 2010-ben és 2016-ban a következő 19. ábra mutatja be.

\section{9. ábra A klasztermenedzsment szervezetek által nyújtott szolgáltatások 2010-ben és 2016-ban}

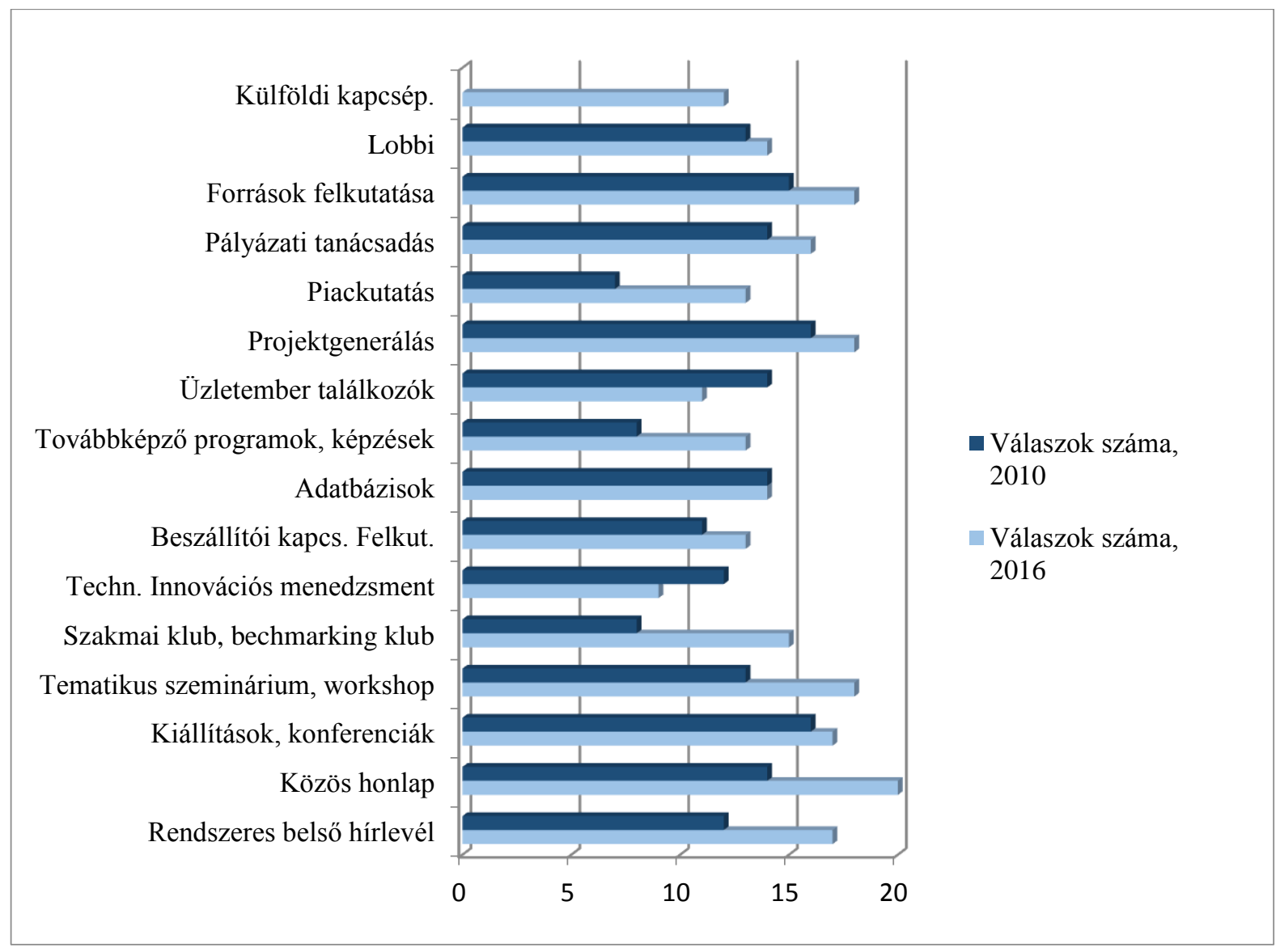

Forrás: Saját szerkesztés

A szolgáltatások számát tekintve (16 db) felmerül a kérdés, hogy valóban szükség van-e ilyen sokféle és nagyszámú szolgáltatásra és valóban mind hozzájárul-e a klaszter fejlődéséhez, illetve, hogy az összes területen hatékonyak tudnak lenni a klasztermenedzsment szervezetek. $\mathrm{Az}$ interjúpartnerek elmondták, hogy nem tervezik a szolgáltatások körének jelentősebb bővítését inkább bizonyos területekre kívánnak koncentrálni. Napjainkban a klasztermenedzserek inkább azzal a kihívással kell, hogy szembesüljenek, hogy valóban 
megtalálják a legfontosabb piaci, illetve klaszteres igényekre épülő szolgáltatásokat és inkább ezekre fókuszáljanak a saját fenntarthatóságuk érdekében.

A klasztermenedzsment szervezetek nagy része rendszeresen aláveti a saját és a klaszter egészének tevékenységét különböző értékelési eljárásoknak, melyek legfőképp a klasztertagok körében valósulnak meg és azok elégedettségét hivatottak felmérni. Ezek a felmérések fontos információt adnak a menedzsmentnek a munkájuk eredményességéről és a klaszter hozzáadott értékéről (KETELS, C. et al. 2013).

A régióban vizsgált klaszterek esetében még nem alakultak ki ilyen típusú belső monitoring rendszerek, viszont az Akkreditációs Eljárást, illetve az Európai Klaszter Kiválósági Kezdeményezést tekintik a két legfontosabb minősítési rendszernek, hiszen ezek egyfajta visszacsatolást nyújtanak mind a klaszter, mind a menedzsment teljesítményéről és iránymutatásként szolgálnak a jövöbeni fejlesztésekhez. A vizsgált klaszterek közül 9-en rendelkeztek akkreditációs címmel, illetve egy klaszter rendelkezik arany, egy ezüst és egy együttmüködés rendelkezett a Klaszter Kiválósági Kezdeményezés bronz fokozatával az interjú időpontjában.

A klasztertagok elégedettségét és a klaszterek iránt érzett elhivatottságát nagyban tükrözi a klasztertagok aktivitása, továbbá, hogy mennyire alakult ki a közös klasztertudat, melynek kiépítése és erősítése szintén a klasztermenedzsment egyik fontos feladata (ANDERSSON, T. et al. 2004, KETELS, C. et al. 2013). A kutatásba bevont klasztervezetők véleménye szerint a tagsági aktivitást tekintve, szinte minden klaszter rendelkezik kevésbé aktív szereplőkkel, akik aránya elmondásuk alapján jellemzően 20-30\% közé tehető, és amely tagok egy része idővel ki is lép a klaszter kötelékéből. Mindemellett érzékelhető volt a válaszokból, hogy a klaszteraktivitás terén is szinte minden klaszterben van egy szük réteg, jellemzően az alapító tagok, akik sokkal aktívabbak és kezdeményezőbbek a később csatlakozó társaiknál, melyek klaszterben kifejtett tevékenysége sokszor csak eseti jellegü, vagy csak egy szük területhez (pl. pályázatok) kapcsolódik. Ez az arány az akkreditált klaszterek tekintetében is hasonló, bár érdekesképpen az akkreditált klaszterek között több volt a kiugró érték. Két akkreditált klaszter esetében ugyanis az interjúpartnerek szerint elenyésző az inaktív tagok aránya, míg szintén egy akkreditált klaszter menedzsere nyilatkozott úgy, hogy a klasztertagoknak csak egy kis százaléka, körülbelül egyharmada tekinthető igazán aktív szereplőnek.

A klasztertudatra vonatkozó kérdés esetében arra kerestem a választ, mennyire gondolkodnak az egyébként önállóan müködő cégek, szervezetek „klaszteres fejjel” és mennyire jellemző, hogy kialakult egyfajta közös gondolkodásmód, esetleg közös megjelenés a klasztertagok között. Erre vonatkozóan az interjúpartnereknek 5-ös fokozatú skálán kellett megítélniük a klasztertudat erősségét, melyre általában 3-as, tehát a „közepesen erős” választ adták. Többen kiemelték, hogy a klasztertudat erőssége is nagyon eltérő a tagok között és nyilvánvalóan összefüggésben áll a szereplök aktivitásával. Ez a megkérdezettek szintjén átlagosan közepesnél gyengébb erősséget jelentett, tehát ahogyan azt a vezetők is megfogalmazták ezen a területen még nagyon sokat kell fejlődniük a klasztereknek. Külön megvizsgálva az akkreditált klaszterek vezetőinek válaszait, meglepő módon nem találtam kiemelkedő értéket, így a klasztertudat erőssége ezen együttmüködések esetében is csak közepesnek mondható. 


Hipotézis 2.: A Dél-alföldi Régió klaszterei kihasználják a klaszteres
együttmüködésekből származó elönyöket, jelentős hozzáadott értéket képviselnek a
klasztertagjaik számára, mely előnyöket erösítésében a klasztermenedzsment
szervezeteknek nagy szerepe van.

A fenti válaszok alapján megállapítható, hogy a vizsgált klaszterek igyekeznek kihasználni a klaszteres együttmüködésben rejlő előnyöket és egy olyan értéklánc mentén kialakítani a klaszter tevékenységeit, amely minden szereplő számára kölcsönös előnyöket és új piaci lehetőségeket jelent. A régió klasztereinek legnagyobb hozzáadott értéke föként a közös kutatás-fejlesztési projektek generálása és a pályázati források elérése terén kiemelkedő. Ezek a területek a jövőben azonban nagy valószínüséggel jelentősen át fognak alakulni, hiszen már jelenleg is sokkal kevesebb pályázati támogatás áll a klaszterek rendelkezésére, de célzott támogatásokra a jövőben sem lehet már számítani. A pályázati források helyett inkább a nemzetközi piacra lépés és nemzetközi kapcsolatok fontossága, továbbá a közös termékek és szolgáltatások kifejlesztése kerülhet előtérbe és annak biztosítása, hogy ezek elegendő értéket jelentsenek a klasztertagoknak a klaszterben maradáshoz.

A klasztermenedzserek számos szolgáltatással igyekeznek a klaszterben való részvétel vonzerejét növelni, mely szolgáltatások egyre inkább a nemzetközi partnerkeresés, valamint a belső és külső kommunikáció erősítése felé mutatnak, és amely szolgáltatások mennyisége helyett, inkább azok hatékonyságán (minőségén) kell, hogy erősítsenek. A régió klasztereinél még nem alakultak ki a tagok elégedettségét mérő belső értékelési eljárások és a közös klasztertudat és a klasztertagok együttmüködési aktivitása is csak közepesnek mondható.

Természetesen a fenti válaszok csak a klasztermenedzserek megítélését tükrözik és ehhez kapcsolódóan érdekes lenne a klasztertagok véleményét is megvizsgálni. Az interjúk kizárólag a klasztertagok aktivitása és a klasztertudat kérdések terén engednek következtetni a klasztertagok hozzáállására, mely területeken még a menedzserek megítélése szerint is nagyon sok fejlesztési feladat áll elöttük.

Ezek alapján a 2. hipotézis részben támasztható alá, mivel a Dél-alföldi Régió klaszterei kihasználják a klaszteres együttmüködésekből származó előnyöket és bizonyos szempontok szerint jelentős hozzáadott értéket képviselnek a klasztertagjaik számára, azonban még számos olyan terület van, amelyek fejlesztése komoly energiákat igényel a klasztermenedzserek részéről, annak érdekében, hogy a tagjaik hosszú távon elégedett és aktív részesei legyenek az együttmüködéseknek. 


\subsection{A régió klasztereinek $\mathrm{K}+\mathrm{F}+\mathrm{I}$ tevékenysége}

A klaszterek $\mathrm{K}+\mathrm{F}+\mathrm{I}$ tevékenységének vizsgálatakor az alábbi kérdésekre kerestem a választ:

- Mennyire jellemző az egyetemek, főiskolák, kutatóintézetek és a vállalkozások közötti együttmüködés a klaszteren belül? Milyen tapasztalataik vannak ezen a téren a klasztervezetőknek?

- Milyen innovációs tevékenységet végez a klaszter és mely klasztertagok kapcsolódnak be ezekbe a tevékenységekbe?

- A klasztertagok mennyire osztják meg egymással a tudásukat, az információikat?

- Mely tényezőket tartanak fontosnak a klasztervezetők az innováció szempontjából és ezek mennyire érvényesülnek a klasztereken belül?

A tudásintenzív klaszterekben nagy szerepe van az oktatási és kutatási szereplőknek, az egyetemeknek, főiskoláknak és egyéb kutatóintézeteknek az általuk megtermelt tudás és annak piacosítása révén (ANDERSSON, T. et al. 2004).

Az elemzésbe bevont klaszterek nagy részében, 20 klaszterből 18 esetben, részt vesz felsőoktatási intézmény (egyetem vagy főiskola) valamint kutatóintézet, teljes jogú, illetve három esetben pártoló tagként. A klaszterben betöltött szerepüket tekintve egy kivétellel ezek az intézmények nem számítanak domináns vagy irányító szereplőnek, hasonló súllyal és intenzitással vesznek részt a klaszterek tevékenységében, mint a vállalkozások, sőt 8 esetben inkább passzívabb szereplőnek számítanak. Arra a kérdésre, hogy mennyire jellemző az együttmüködés az oktatási és kutatási, valamint a vállalkozói szféra szereplöi között a klasztermenedzserek fele olyan konkrét területekről és tevékenységekről számolt be, amelyeknél jól tudták hasznosítani ezen intézmények erősségeit.

$\mathrm{Az}$ egyetemeknek, főiskoláknak, illetve az egyéb kutatási intézményeknek az alábbi tevékenységekben van meghatározó szerepe:

- Kutatási témák és irányok meghatározása.

- $\mathrm{K}+\mathrm{F}+\mathrm{I}$ tevékenységek megvalósítása.

- Kutatás-fejlesztéshez kapcsolódó pályázatokban való részvétel.

- Oktatás és speciális továbbképzések biztosítás a tagvállalatok számára.

- Duális képzés megvalósításában való kooperáció.

- Szolgáltatási tevékenységek: különböző mérési szolgáltatások, kutatási- és labor kapacitások, teszthelyszínek biztosítása.

A különböző cégek között megvalósuló együttmüködést sokszor befolyásolhatja, nehezítheti a szereplők eltérő motivációja vezetési, irányítási rendszere és belső folyamatai (DICKEN, P. MALMBERG, A.). Különösen igaz ez azon klaszterekre, ahol nem csak vállalkozások, de teljesen eltérő szervezeti, müködési háttérrel rendelkező egyetemek, kutatási intézmények is részt vesznek a kooperációban. Az együttműködés során tapasztalt problémákra az interjúk során is kitértek a klasztervezetők, melyek közül az egyetemeknél tapasztalható hierarchikus döntéshozatali rendszerből eredő túlzott idő- és adminisztrációs igényt fogalmazták meg legtöbben, de megemlítésre kerültek az eltérő nyelvezetből és motivációkból adódó problémák, valamint a szolgáltatások túlárazásának kérdése is.

Az egyik klasztervezető a következőképpen fogalmazott:,,Az egyetemeknél a lassúság és a nehézkesség a legnagyobb probléma. Nem csak a döntéshozatal, de a munkavégzés és az eredmények kiadása terén is." (7.)

A klasztermenedzserek szerint a klaszter egy közös fórumot biztosít a vállalkozások és a kutatási intézmények számára az együttmüködésre, a klasztermenedzserek pedig hídképző szervezetként próbálják meg ezt előremozdítani. „A kkv-k és az egyetemek nyelvezete nagyon különbözö, nem értik egymást, mi klasztermenedzserek próbálunk meg közvetíteni, kvázi „forditani”. A mi szerepünk, hogy hídképzöként kommunikációs csatorna legyünk, mivel 
mindkét fél elfogad, elfogadják a kéréseinket, javaslatainkat. Az egyetemeknél lévö tudásanyagot és potenciált próbáljuk hirdetni a kkv-k körében."- fogalmazta meg a 7. interjúalany. (7.)

Volt olyan klasztermenedzser is, aki azt emelte ki, hogy a kis-és középvállalkozásoknak is fel kell készülni az egyetemekkel való együttmüködésre és el kell érniük egy fejlettségi szintet ahhoz, hogy szoros együttmüködésben tudjanak dolgozni a kutatás terén.

„Az egyetem mellé felnőni (már csak a nagyságrendjéböl fakadóan is) igen nagy feladat, de az innovatív klaszter szakaszban már méltó partnerei lehetünk egy egyetemnek és elérhetjük annak ingerküszöbét." (10.)

A klaszterek döntő többségének volt már közös kutatás-fejlesztési projektje, hat esetben pedig a tagok inkább önállóan végeznek innovációs tevékenységet, de a klaszteren belül még nem indultak meg az ilyen irányú együttmüködések. Két akkreditált klaszter esetében olyan konkrét eredménye is lett a közös kutatás-fejlesztésnek, amely már piacon eladható termék formájában is realizálódott. Többen kiemelték az innovációs projektek kapcsán a pályázatok jelentőségét és szükségességét, mivel ezek a források nagy lendületet adtak a közös kutatásoknak, fejlesztéseknek.

A klasztermenedzserek megítélése szerint átlagosan a klasztertagok egyharmada végez valamilyen jellegü $\mathbf{K}+\mathbf{F}+\mathbf{I}$ tevékenységet, jellemzően az alapító tagok. Kivételt képez ez alól az a két technológia intenzív akkreditált klaszter, ahol az iparági sajátosságokból (gyógyszeripar, egészségipar), illetve a klaszter koncentrált összetételéböl adódóan ez az arány eléri a $80 \%$-ot.

A 2010-es elemzés során a megkérdezett klasztervezetők fele nyilatkozott úgy, hogy végez az innovációs aktivitás fokozására irányuló tevékenységeket, azonban a konkrét ilyen jellegü szolgáltatások között csak az alábbiakat sorakoztatták fel, melyek inkább csak általánosságban támogatják a $\mathrm{K}+\mathrm{F}+\mathrm{I}$ tevékenységeket:

- információnyújtás

- pályázatokhoz kapcsolódó forrástérkép, pályázat tanácsadás, pályázatkészítés

- új technológiák, legjobb gyakorlatok bemutatása

- rendezvények szervezése

Ehhez képest 2016-ban már a klasztermenedzsment szervezetek fele nyújtott célzott innováció menedzsment és technológia transzfer szolgáltatást is a klasztertagok számára, sőt volt olyan interjúalany, aki kifejezetten ezeket a tevékenységeket jelölte meg a menedzsment erősségének és legfontosabb szerepének.

Arra a kérdésre vonatkozóan, hogy jellemzően mely szervezetek végeznek innovációs tevékenységet, kik a legfőbb innovátorok a klaszteren belül, a klasztermenedzserek föként azokat a nagy cégeket emelték ki, akik egyébként is ,,innovációs nyomás alatt vannak” (5.) és elegendő tőke és kapacitás áll a rendelkezésükre. Vannak olyan területek pl. egészségipar, gyógyszeripar, szoftveripar, ahol „szinte mindenki rá van kényszerítve” (8.), így ezeken a területeken nem csak a nagy cégek, de a kis- és középvállalkozások is aktív szereplői a $\mathrm{K}+\mathrm{F}+\mathrm{I}$ projekteknek. Több esetben kiemelték továbbá a klaszter vezető cégeit, akik jellemzően az alapító körből kerülnek ki és amely vállalkozások már a kezdetekkor felismerték a kooperáció, valamint a tudásmegosztás jelentőségét az innovációs projektekben.

A hatékony innováció egyik legfontosabb feltétele a szereplők (egyetemek, vállalkozások, kutatási szervezetek stb.) közötti folyamatos kommunikáció és együttmüködés, mely hozzájárul a tudástranszfer folyamatokhoz, különösen tekintettel az innováció szempontjából kiemelten fontos rejtett vagy tacit tudás átadásához. (PORTER, M. E. - SöLVELL, Ö. 1998, TÖDTLING, F. - TRIPPL, M. 2005). Ezekben a folyamatokban kitüntetett szerepe van a klasztereknek, hiszen olyan környezetet biztosítanak, ahol a résztvevök rendszeresen 
találkoznak, kommunikálnak egymással, információt és véleményt cserélnek és közösen valósítanak meg különbözö projekteket, ezzel is hozzájárulva az innovációs szakadékok áthidalásához (KETELS, C. et al. 2012).

A tudásmegosztást és kreatív együttgondolkodást ösztönző közegnek a megteremtése a klasztermenedzserek egyik legfontosabb feladatának mondható. Ennek érdekében a megkérdezettek a szakmai és egyéb programok szükségességét emelték ki. A különböző workshopok, egyeztetések, benchmarking klubok, egymás szakmai megismerésében játszanak fontos szerepet, de a vezetők nagy hangsúlyt fektetnek az olyan típusú csapatépítő rendezvényekre is, ahol a tagok akár ,egy pohár bor mellett osztják meg egymással a gondolataikat" (19.).

Az együttmüködő partnerek között kialakult bizalmi viszonyt a klaszterek kialakulásának egyik alapfeltételeként szokták emlegetni, de a tudásátadási és innovációs folyamatokban is kiemelkedő szerepe van (ANDERSSON, T. et al. 2004), melyet az egyik interjúpartner a következőképpen fogalmazott meg: „Nagy szerepe van a bizalmi kapcsolatnak, de erre időt kell szánni, találkozni kell személyesen minél többet. A tacit tudás nem adható át másképpen. Erös személyes kapcsolatok, egymás iránti elkötelezödés a fontos. (16.)

A szakmai és a személyes bizalom egymást kell, hogy erősítsék, ezért is tartotta az egyik klasztervezetö fontosnak megjegyezni, hogy „, a bizalomi légkör mellett fontos, hogy betartsák az üzleti élet szabályait”. (19.)

A hatékony tudásmegosztás kialakulása azonban nem automatikus folyamat, időt kell szánni rá és tudatos eszközökkel folyamatosan ösztönözni kell. Ezt a klasztermenedzserek igyekeznek minél többféle módon elősegíteni, támogatni. „Az egymástól tanulás, illetve a tudásmegosztás a kezdetekben nehézkesen indult, verseny illetve piacféltés miatt. Késöbb a klasztermenedzsment cég aktív közremüködése és a közös projektek révén ez beindult és egyre inkább jellemzövé válik.” fogalmazta meg az egyik klasztervezető. (7.)

A tudásmegosztás a klasztertagok között jellemzően a klasztertalálkozókon, a szakmai rendezvényeken, benchmarking klubokon zajlik. Három klaszter esetében a tudásmegosztás és az információcsere egyelőre még leginkább csak a klasztermenedzsment szervezet közvetítésével valósul meg. A kutatás-fejlesztés során nagyon fontos a tapasztalatcsere és egymás tevékenységének, technológiájának alapos megismerése, ehhez gyakran kell találkozni és érdemes egymás tevékenyégét, annak helyszínét, körülményeit is megismerni. „A személyes kapcsolat nagyon fontos, de ehhez rengeteg idö kell. A gépiparban nagyon fontos, hogy elmenjenek a tagok egymáshoz és megismerjék a környezetet, az alkalmazott technológiát." (1.)- hangsúlyozta az egyik interjúpartner.

A tudásmegosztás és az információcsere kapcsán hét klaszter említette a közös kommunikációs felületek, platformot, adatbázisok fontosságát. Ezek segítségével, sokkal könnyebben és gyorsabban oszthatóak meg az információk, két esetben ennek elősegítése érdekében már használnak is közös kommunikációs felületet. Volt olyan klasztervezető, aki a közös fizikai infrastruktúrát, akár egy közös inkubátorház létrehozását is lényegesnek tartaná, hiszen ebben az esetben a tagok fizikai közelsége nagyban elösegítené a tudásmegosztási tevékenységeket és a közös fejlesztéseket. 
A következökben azt vizsgáltam, hogy mely tényezők azok, amelyek fontosak a klaszterek innovációs tevékenysége szempontjából és ezek közül melyeket kell erősítenie a régió klasztereinek. Erre a kérdésre csak azon klasztervezetőket kértem meg, hogy válaszoljanak, akik saját elmondásuk szerint végeznek $\mathrm{K}+\mathrm{F}+\mathrm{I}$ tevékenységet és ennek erősítése a klaszter legfontosabb céljai között szerepel. Ez alapján 13 interjúpartner töltötte ki a kérdésekhez kapcsolódó táblázatokat.

A kérdéseim 5 fö csoportra osztva 18 innovációs tevékenységeket elősegítő tényezőt foglaltak magukban.

A csoportok összefoglaló neveit és az azokhoz tartozó innovációt ösztönzö tényezöket az alábbiakban mutatom be:

„K+F eröforrások és bázis”

1. Erős egyetemi kutatás-fejlesztési erőforrások és háttér

2. Erös vállalati $\mathrm{K}+\mathrm{F}$ háttér

3. Erős specializáció valamely területen

4. A teljes innovációs értéklánc megjelenése a klaszteren belül

„K+F szolgáltatások”

5. Innováció menedzsment tevékenység a klaszteren belül

6. Külső szolgáltatások könnyebb igénybevétele (pl. technológia transzfer)

7. Innovációs források (pályázat, hitel, tőkebefektetés) könnyebb elérése

8. $\mathrm{K}+\mathrm{F}+\mathrm{I}-\mathrm{hez}$ szükséges infrastrukturális vagy humán erőforrások könnyebb igénybevétele

\section{„Tudásátadás és kollektív tanulás”}

9. Tudástranszfer tevékenység a tagok között

10. A tacit tudás könnyebb átadása a személyes kapcsolat révén

11. Kollektív tanulás a klaszteren belül

„Verseny és piacok elérése”

12. Nemzetközi piacok közös elérése

13. Gyorsabb piacra jutás a klaszter segítségével

14. Tagok közötti verseny élénkítő hatása

\section{„Együttmüködések és kockázatcsökkentés”}

15. A rendelkezésre álló $\mathrm{K}+\mathrm{F}+\mathrm{I}$ erőforrások egymás közötti megosztása

16. Egyéni kapcsolatrendszer megosztása

17. Interszektoriális együttmüködések a klaszteren belül

18. Közös kockázatvállalás a közös projektek révén

Az első kérdésem arra irányult, hogy a felsorolt innovációs tevékenységeket támogató tényezőket mennyire tartják fontosnak az interjúalanyok a klaszterek szempontjából.

Az interjúpartnerek ötfokú Likert-skálán jelölhették meg a véleményüket

1 -Egyáltalán nem fontos a klaszterek innovációs tevékenysége szempontjából.

2 - Kis mértékben fontos az innovációs tevékenységek szempontjából.

3 - Közepesen fontos a klaszterek innovációs tevékenysége szempontjából.

4 -Inkább fontos a klaszterek innovációs tevékenysége szempontjából.

5 -Teljes mértékben fontos a klaszterek innovációs tevékenysége szempontjából. 
A 20. ábra tartalmazza a megkérdezett klasztervezetők összesített válaszait csoportonként százalékos formában.

A második kérdés esetében már azt kellett megjelölniük az interjúalanyoknak, hogy ezek a tényezők mennyire erősek, mennyire érvényesülnek az adott klaszter esetében. Ebben az esetben szintén ötfokú Likert-skála segítségével súlyozhatták az adott tényezők erősségét a saját klaszterükben. (21. ábra)

1 - Egyáltalán nem érvényesül a klaszteren belül.

2 - Kis mértékben érvényesül a klaszterben.

3 - Közepesen érvényesül a klaszterben.

4 - Inkább érvényesül a klaszterben.

5-Teljes mértékben érvényesül a klaszterben.

\section{0. ábra A klaszterek innovációs tevékenységét támogató tényezők fontossága a klasztermenedzserek véleménye alapján}

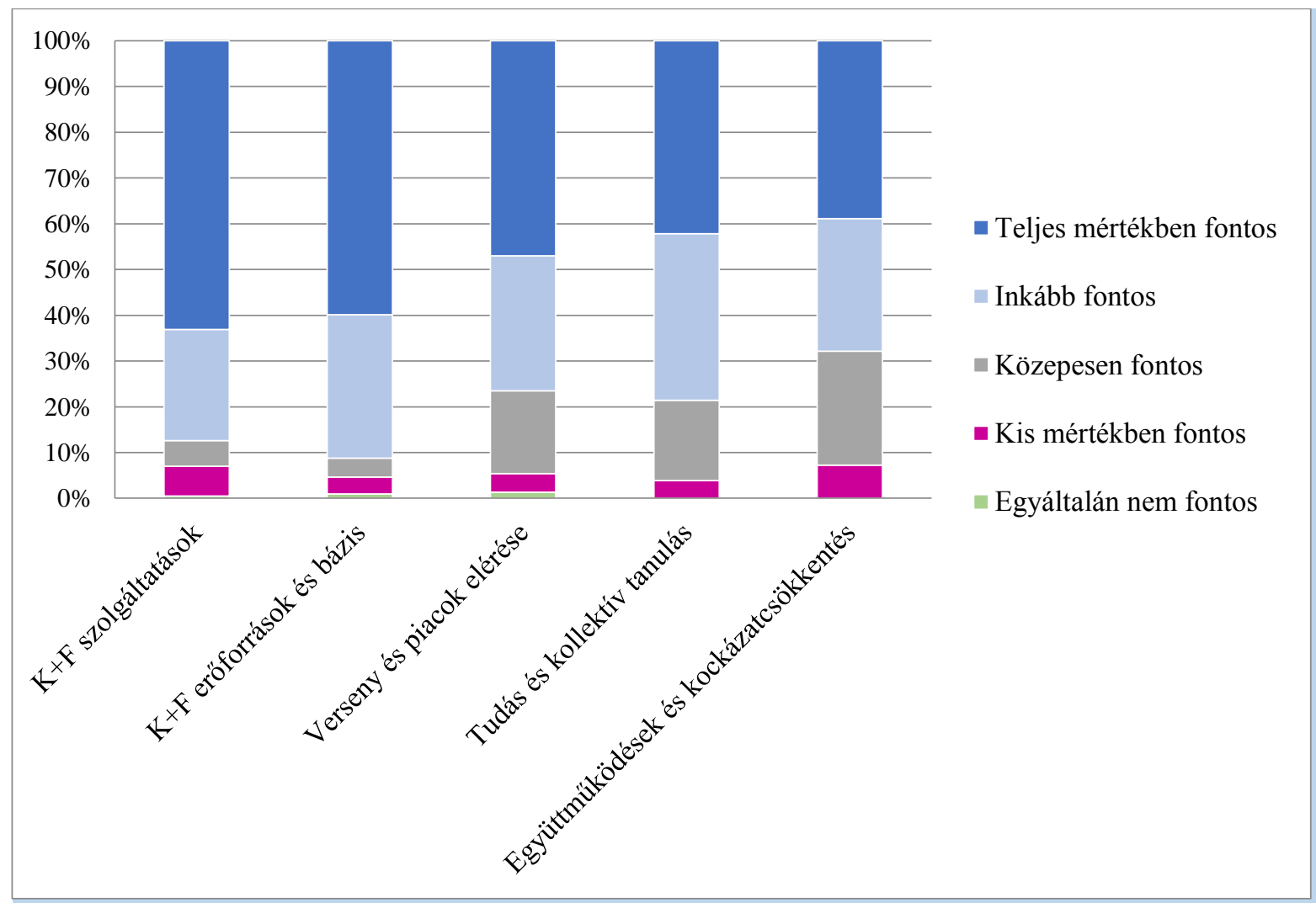

Forrás: Saját szerkesztés

Ahogyan a 20. ábra is mutatja a klaszterek az innováció szempontjából a különböző $\mathrm{K}+\mathrm{F}$ tevékenységeket támogató szolgáltatásokat és a $\mathrm{K}+\mathrm{F}$ eröforrásokat és bázist tartják a legfontosabbnak. A $K+F$ szolgáltatásokat a klasztervezetők 63,08 \%-a értékelte teljes mértékben fontosnak és $24,30 \%$-a inkább fontosnak, míg a $K+F$ eröforrások és bázis esetében 59,91\% teljes mértékben és 31,34\% inkább fontosnak tartotta az adott csoportot az innováció szempontjából. Összesítve azokat a válaszokat, amelyek szerint az adott tényező inkább fontos (4-es) és teljes mértékben fontos (5-ös) látható hogy a felsorolt innovációt támogató és erősítő csoportok közül négyet a klasztervezetők legalább 75\%-a jelentősnek ítélt meg a klaszterek innovációs tevékenysége szempontjából. A csoportokon belüli rangsorban legkevésbé fontosnak ítélt Együttmüködések és kockázatcsökkentésen belüli tényezöket is 
67,88\%-uk tartotta közepesnél fontosabbnak, tehát még ezen tényezők megléte is meghatározónak mondható az innováció szempontjából.

A második kérdés esetében, amikor azt kellett értékelniük, hogy az adott tényezök mennyire jelennek meg a saját klaszterükben, már jóval visszafogottabbak voltak a klasztervezetők. A $K+F$ eröforrások és bázis csoporton belüli tényezőket például az interjúpartnerek 67,05 \%-a jelölte meg, hogy inkább vagy teljes mértékben érvényesül a klaszterben szemben azzal, hogy 91,24\%-uk érezte ezt inkább vagy teljes mértékben fontosnak az innováció szempontjából. Hasonlóak az értékek a $K+F$ szolgáltatások esetében is, hiszen míg a klasztervezetők 87,38 \%-a jelölte meg a 4-es és 5-ös választ az innováció szempontjából, csak 57,54\%-a klaszteren belüli erősség esetében. Minden csoportnál hasonló eredményeket kapunk, tehát a klasztervezetők nagy része fontosnak értékeli az egyes tényezőket az innováció szempontjából, mégis úgy érzik, ezek a tényezők még nem érvényesülnek megfelelő súllyal a klaszterük müködésében, így ezek ösztönzésére, fejlesztésére további erőforrásokat kell allokálniuk.

\section{1. ábra A klaszterek innovációs tevékenységét támogató tényezők erőssége a klaszterekben}

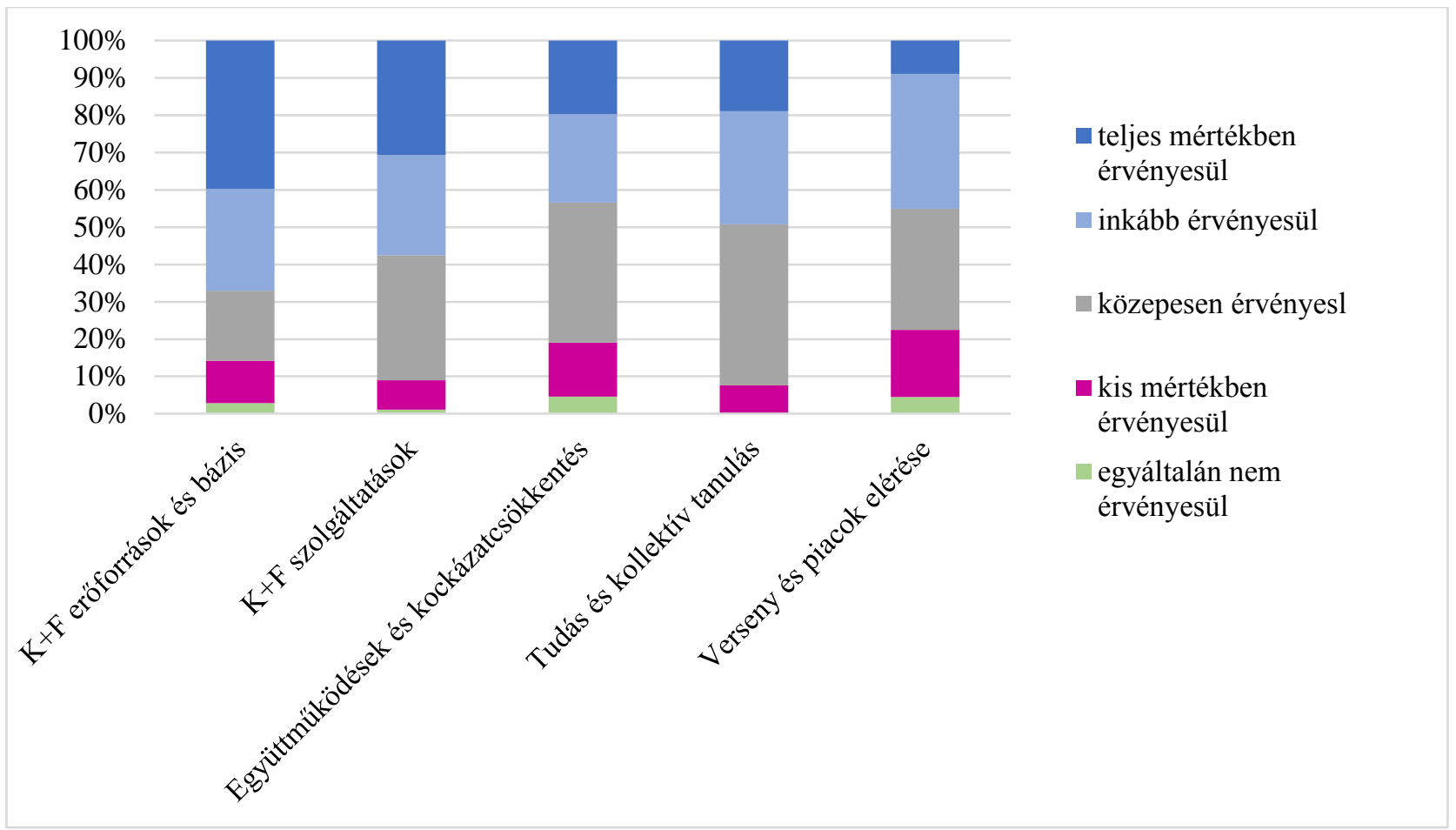

Forrás: Saját szerkesztés

A csoportokon belüli tényezők megoszlását a terjedelmi korlátok miatt csak az innováció, valamint a klaszterek szempontjából legerösebb csoportok esetében mutatom be részletesebben.

Az innováció szempontjából legerősebb csoport a $K+F$ szolgáltatások közé sorolt tényezők közül a $K+F+I$ tevékenységekhez szükséges eröforrások (infrastrukturális és humán) és a külső innovációs források könnyebb igénybevétele emelhető ki (22. ábra). Ezek alapján az általános müködési területeken felül a kutatás-fejlesztésben is megmutatkozik a külső (jellemzően pályázati) források megszerzésének jelentősége, mint a közös együttműködések egyik ,hajtóereje”.

A klaszterek szempontjából legerősebb csoport a $K+F$ erőforrások és bázis esetében az erős egyetemi $K+F$ bázis és az erős specializáció tényezők bizonyultak meghatározóbbnak a többinél (23. ábra), Ez azonban azért érdekes és részben ellentmondásos, mivel a 
klasztermenedzserek elmondása alapján az egyetemi együttmüködések még nem tekinthetőek meghatározónak a klasztereken belül, mégis az innovációs területek jelentős ösztönző tényezőként értékelik azok kutatás-fejlesztési erőforrásait.

22. ábra A K+F szolgáltatások csoporton belüli tényezők megoszlása (az innováció szempontjából)

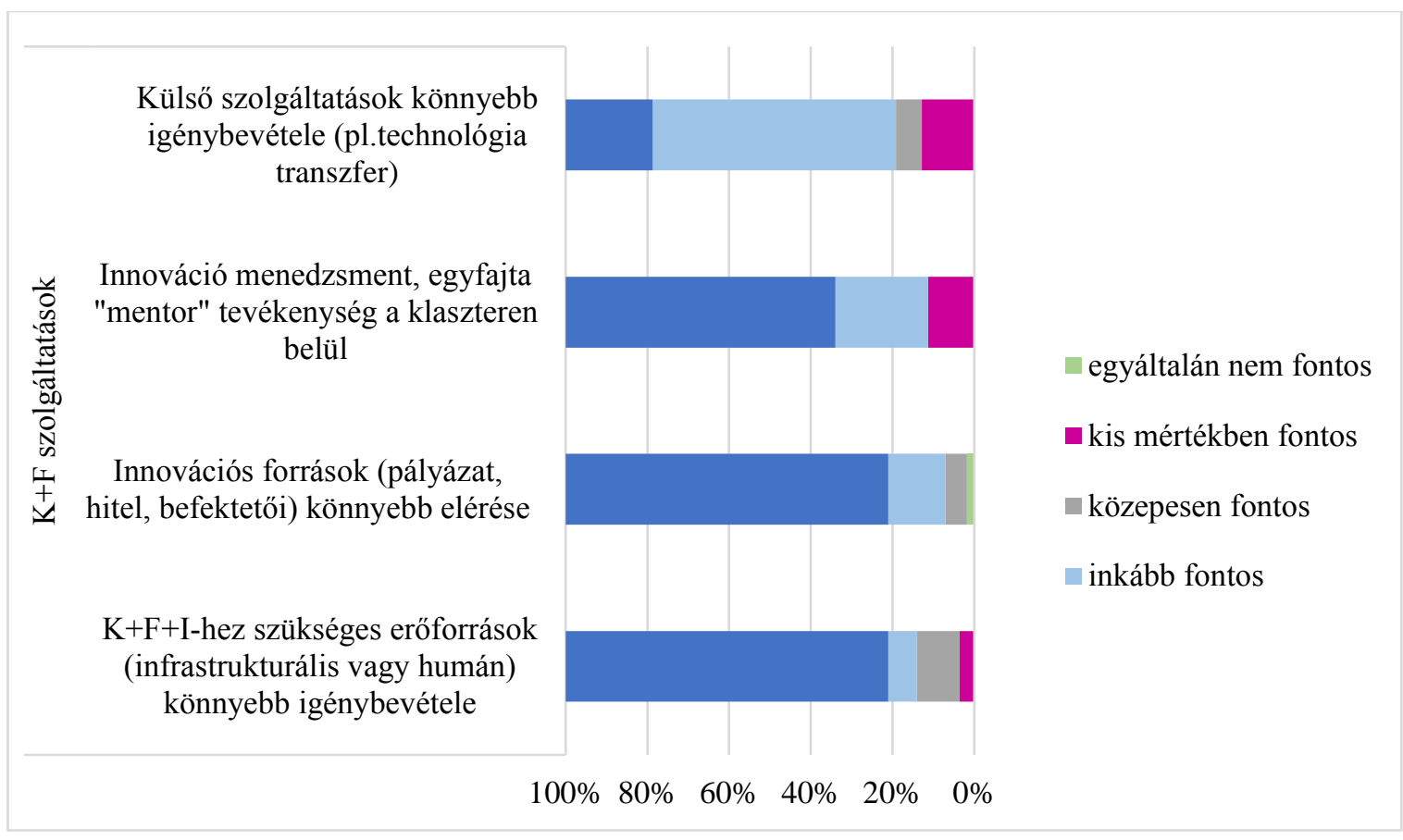

Forrás: Saját szerkesztés

\section{3. ábra A K+F erőforrások és bázis csoporton belüli tényezők megoszlása (a klaszteren} belül)

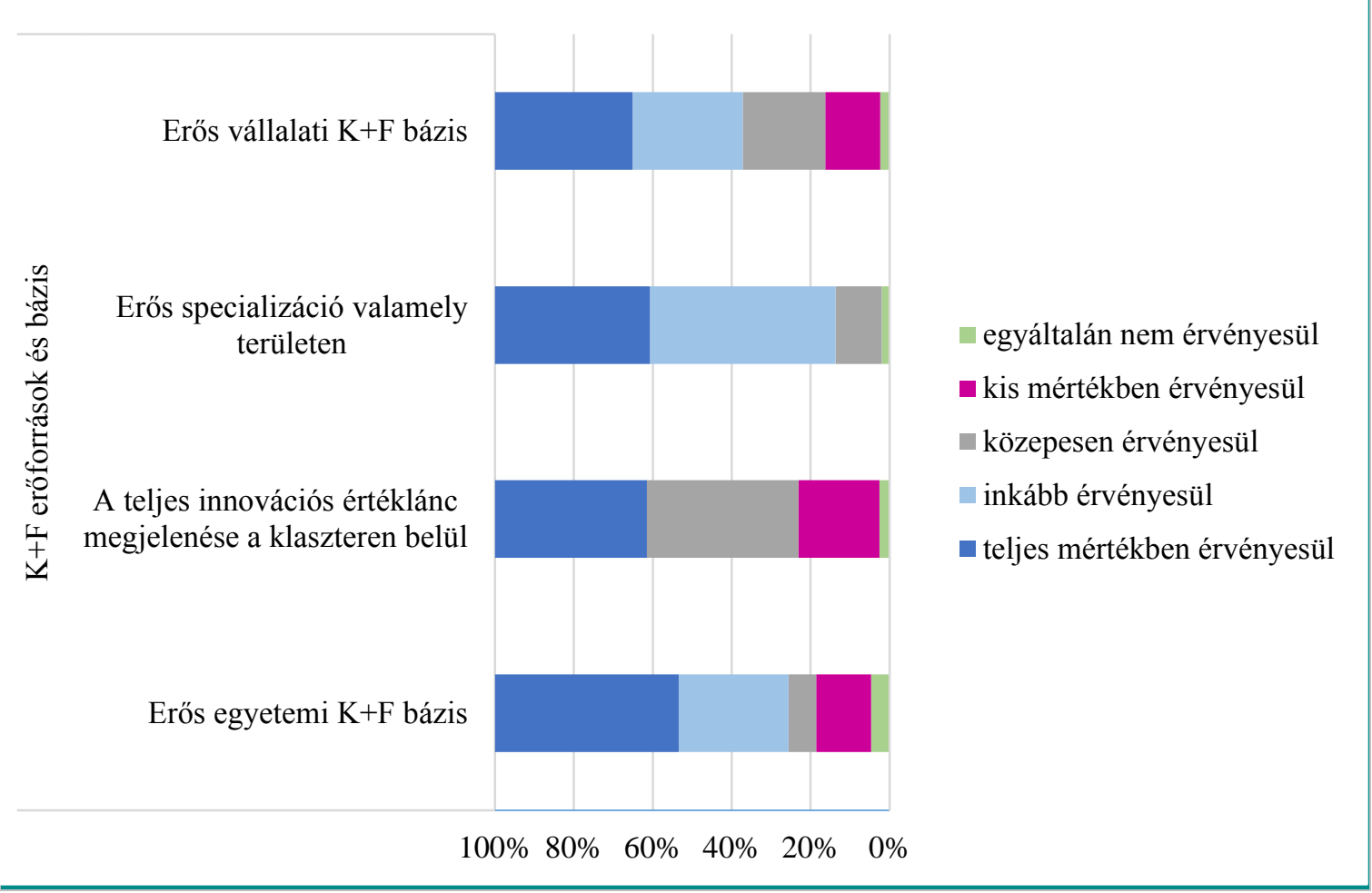


Hipotézis 3.: A Dél-alföldi Régió klaszterei a regionális tudáscentrumok köré összpontosulnak és magukban foglalják a kutatás-fejlesztési tevékenységek legfontosabb szereplőit, ezért kiemelkedő kutatás-fejlesztési és innovációs tevékenységet folytatnak.

A klaszterek $\mathrm{K}+\mathrm{F}+\mathrm{I}$ tevékenységeit vizsgálva megállapítható, hogy hazai viszonylatban, a Dél-alföldi Régióban igen magas arányban alakultak ki a tudományos és az ipari kiválósági területek köré szerveződő együttmüködések. Ezen együttműködések magukban foglalják a tudományos és vállalkozói élet legfontosabb szereplőit és egyre több közös $\mathrm{K}+\mathrm{F}$ projektet valósítanak meg. Bár az egyetemek és kutatási intézmények a klaszterek nagyon nagy részében részt vesznek teljes jogú, vagy pártoló tagként, azok szerepe nem mondható meghatározónak még akkor sem, ha a klasztermenedzserek a klaszter innovációs tevékenysége szempontjából fontosnak ítélik meg ezen szervezetek erőforrásait.

A régió klaszterei a közös innováció, a tudásmegosztás és a kollektív tanulás terén még hosszú fejlödési folyamat előtt állnak. A klasztervezetők többsége tisztában van azzal, mely tényezők támogatják az innovációs folyamatokat, azonban ezek közül még csak nagyon keveset ítélnek megfelelően erősnek a klaszterek tevékenységében.

A fentiek alapján a 3. hipotézis csak részben igazolható, mivel a Dél-alföldi Régió klaszterei valóban jelentős tudásbázisra és tudáscentrumok köré épültek, azonban azok innovációs tevékenysége gyengébb a vártnál és számos területen fejlesztést igényel. 


\subsection{A klaszterek finanszírozása, pénzügyi és szakmai fenntarthatósága, jövőbeni fejlődése}

Egy klaszter tevékenysége és müködése csak akkor tekinthetö igazán sikeresnek, ha mind szakmai, mind pénzügyi szempontból is hosszútávon fenntartható.

A klasztermenedzsment szervezetek fontos feladata az együttmüködés anyagi hátterének finanszírozási forrásainak megteremtése, hiszen a klaszterszervezetek müködése, a közös tevékenységek, megjelenések jelentős költségekkel járnak. Ezeket a költségeket a klaszterek tagdíjakból, szolgáltatási bevételekből és külső egyéb szervezetek által nyújtott támogatásokból fedezik. A klaszterek finanszírozási szerkezetében még nagy jelentősége van a külső támogatási forrásoknak, de az idő előrehaladtával, a hosszabb müködési múlttal rendelkező klaszterek esetében már megfigyelhető egyfajta pozitív változás és a bevételek között egyre nagyobb hányadot képviselnek a klasztertagoktól és a különbözö szolgáltatásokból származó üzleti bevételek (Ketels, C. et al 2013).

A vizsgálatba bevont klaszterek közül hét esetben a klaszter müködését kizárólag a tagdíjakból fedezik, ami elég magas tagdíjra enged következtetni. A szolgáltatásokat, mindössze csak 2 interjúalany említette, mint lehetséges bevételi forrást. (24. ábra)

\section{4. ábra A klaszterek finanszírozási forrásainak megoszlása (válaszok száma)}

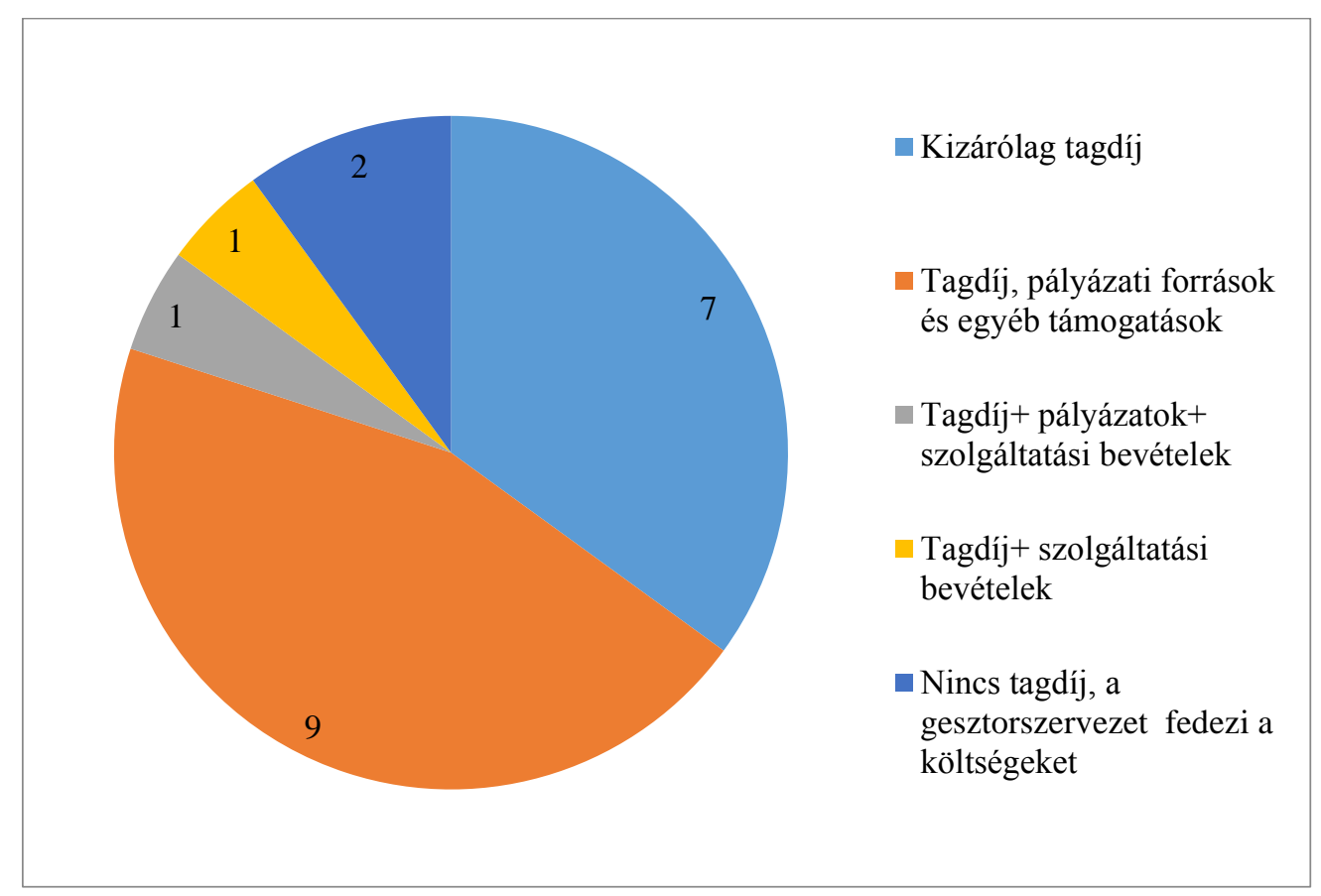

Forrás: Saját szerkesztés

A jövőbeni pénzügyi szempontú fenntarthatóságra vonatkozóan öt klasztervezető nyilatkozott úgy, hogy a pályázati támogatások nélkül a klaszter biztosan nem tudná fenntartani a tevékenységét. Az interjúpartnerek nagyobb része (15 klasztervezető) viszont úgy véli, hogy a tagdíjakból, szolgáltatási és egyéb bevételekből támogatások nélkül is képes lesz finanszírozni a müködést, de a külső források nélkül fennáll a veszélye, hogy nem tudnak fejlödni, szintet lépni, hiszen a klaszterek tevékenysége még nem vált önfenntartóvá, így szükség van a külső segítségre, mind anyagi, mind szakmai szempontból.

Az egyik klasztervezető véleménye szerint , ha a központi pályázati támogatások nem állnak rendelkezésre, akkor a klasztereknek a külföldi példák alapján kell müködniük. A tagoknak invesztálniuk kell a müködésbe, de ehhez meg megfelelö üzleti terv szükséges. Nem lehet kihagyni törzsfejlödési fázisokat, azokhoz viszont külsö forrás szükséges." (1) 
Külön megvizsgálva az akkreditált klaszterek által adott válaszokat egy kicsit árnyaltabb kép mutatkozik. Ezen klaszterek esetében a klasztermenedzsment szervezetek kevésbé építenek a külső pályázati forrásokra és nagyobb aránnyal jelennek meg a tagdíjak a bevételi szerkezetben. Ez feltételezhetően abból is adódik, hogy a fejlettebb életciklusban járó klaszterek már sokkal inkább a közös kutatás-fejlesztési projektekre helyezik a hangsúlyt és inkább ezen tevékenységek esetén vesznek igénybe külső forrásokat, továbbá a tagok is hajlandóak magasabb tagdíjat fizetni, hiszen egyértelmüen kimutathatóak az együttműködésből származó előnyök a szereplők számára. Az akkreditált klaszterek határozottabbak voltak a tekintetben is, hogy a pályázati források megszünésével a tagdíjak emelésével és külső szolgáltatásokból fedezni tudnák a klaszterszervezet és az alapvető közös tevékenységek (külső megjelenések, képzések, közös rendezvények) költségeit.

Voltak olyan klasztervezetők, akik a klaszterek fenntarthatóságát kevésbé a közvetlen pályázati forrásoktól teszik függővé, sokkal inkább a gazdasági környezettől és az egyéb támogatások pozitív hatásaitól:

„Az a klaszter, akinek gazdaságilag életképes termékei vannak, az a klaszter meg fogja állni a helyét. A nemzetközi megjelenés támogatása lenne fontos." (4)

A klaszterek pénzügyi helyzete még nem tekinthető elég stabilnak és a menedzsment számára a legnagyobb kihívást sokszor az anyagi háttér megteremtése és a folyamatos aktivitás fenntartása jelenti a klasztertagok részéről. Kizárólag a tagdíjakból történő finanszírozás viszonylag magas tagdíjat feltételez, amely esetében a klaszteres együttmüködésnek jelentős gazdasági elönyöket kell biztosítania a résztvevőknek, hiszen csak ebben az esetben fogják finanszírozni a müködés teljes költségét. A szolgáltatási bevételek generálása lehetséges megoldás lehet a klasztermenedzsment tevékenységének fenntartására, de ez egyelöre még nagyon kevés klaszter esetében valósul meg, hiszen ehhez olyan minőségü és tartalmú szolgáltatásokra van szükség, amely iránt a tagok és akár külső piaci szereplők részéről is fizetőképes kereslet mutatkozik.

„Egyértelmüen az igény alapú szolgáltatási portfolió kialakitása a fenntarthatóság záloga, amiért vállalkozói díjat kap a klaszter." (20)

A klaszterek támogatási forrásoktól való függetlenedési törekvéseit és a klasztermenedzsment tevékenységének piacról történő finanszírozásának igényét több klasztervezető is kiemelte, az egyikük az alábbi szavakkal: „Ha a kialakult kapcsolati hálót és a közös szakmai pool-ok létrehozását, a piacra jutásra, piacszerzésre lehetne használni, akkor le tudnánk válni a „köldökzsinórról”. (7.)

Az európai uniós támogatási rendszerben már felismerték a pénzügyi források piactorzító jellegét és egyre inkább előtérbe kerültek azok a nem anyagi jellegü ösztönzők pl. tanácsadások, képzések egyéb szolgáltatások, amelyek hatékonyan elő tudják mozdítani egy klaszter versenyképességét (MEIER ZU KÖCKER, G. - MÜLlER, L. 2015).

A nem pénzügyi jellegű támogatások a 2007-2013-as időszakban még nem szerepeltek a hazai klaszterfejlesztési programok eszközei között, azonban a régió klasztervezetőinek nagy többsége örömmel venné az ilyen jellegü támogatásokat és ezek közül a kapcsolatépítő események és közös kommunikációs platformok biztosítását tartották a legfontosabbnak, de a közös infrastruktúra, különböző partnerközvetítő rendezvények, kedvező kamatozású kölcsönök és a müködéssel kapcsolatos mentoring tevékenység is nagyban segítené a munkájukat. (25. ábra) 


\section{5. ábra A nem pénzügyi támogatások közül mit tartanak fontosnak a klasztervezetők}

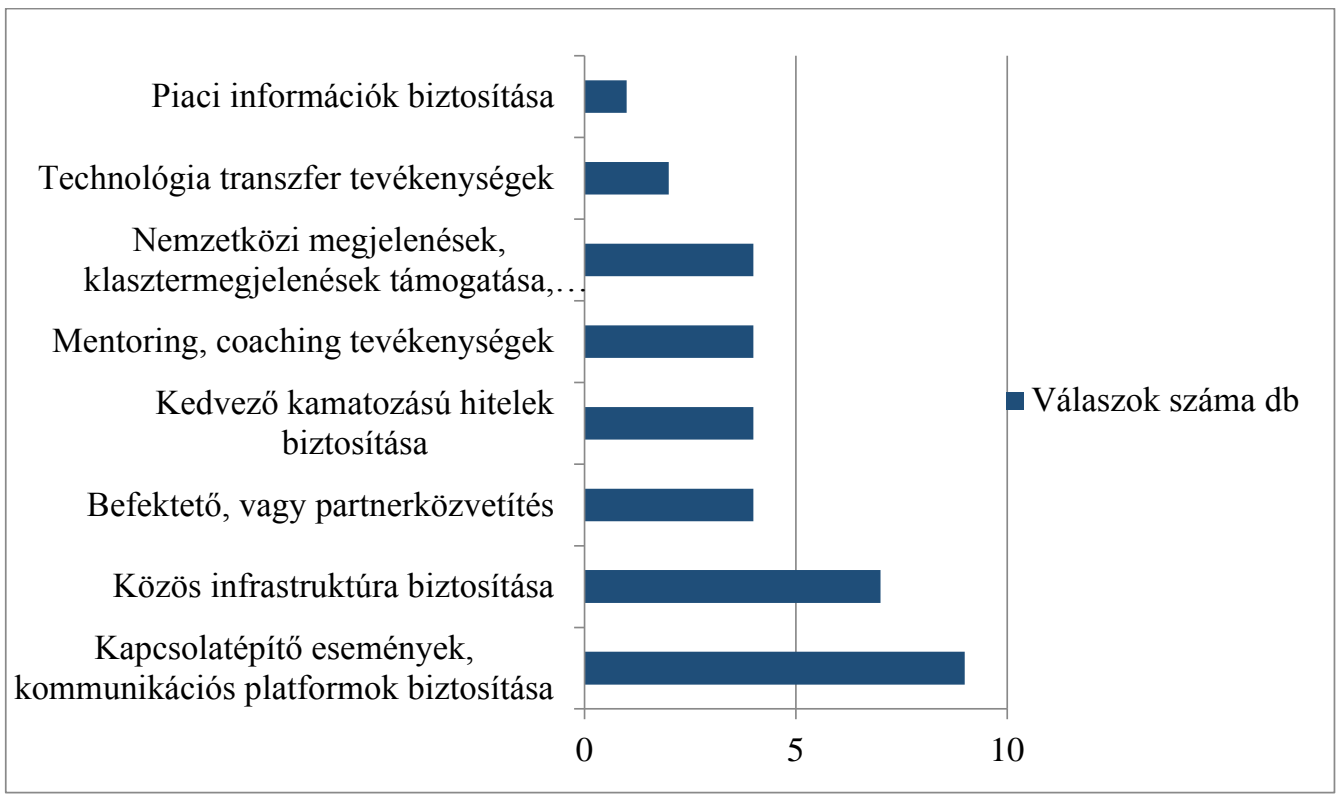

Forrás: Saját szerkesztés

A nem pénzügyi támogatásoknak több szempontból is fontos szerepe lehet. Egyrészről sokkal ellenőrizhetőbbek és célzottabban segítik a klaszter fejlődési folyamatait, hiszen csak megadott területeken érhetőek el, másrészről ez a típusú támogatási forma nem jelent motivációt azon szereplök számára, akik a klaszterre csak a pályázati források lehívásának eszközeként tekintenek. Az egyik interjúpartner ezt kifejezetten kritikusan fogalmazta meg: „Nagyon megosztottak a klaszterek, 50\%-uk jól müködö, célokkal rendelkezö, a másik fele csak a források lehívására jött létre. Ezért lehet nagy jelentösége a nem pénzügyi támogatásoknak, amelyek kiszürik a forrásvadászokat." (16)

Mivel nem elvitatható a klaszterek létrejöttében a pályázati források ösztönző szerepe, a klasztervezetők nagy részének véleménye alapján továbbiakban is szükség lenne a külső pénzügyi és nem pénzügyi jellegű támogatásokra az eredményes müködéshez és a fejlődéshez.

A jól müködő, versenyképes klaszterek esetében is fontos, hogy nyomon kövessék a legújabb iparági, szakmai és klaszteres irányokat, trendeket és ezekhez illeszkedve a stratégiájukat, céljaikat és tevékenységüket rendszeresen meg tudják újítani. A nemzetközi klaszteres elemzések és új irányvonalak alapján a klaszterek jövőbeni fejlődése és továbblépése leginkább az ágazatközi és nemzetközi együttmüködésekben rejlik, azonban ezeket a lehetőségeket még kevéssé használják ki a régió klaszterei (MEIER ZU KÖCKER, G. - MÜLLER, L. 2015). Az elemzésbe bevont klaszterek közül a többségnél egyáltalán nincs szektorokon átívelő tevékenység és csak hat esetben volt már ilyen irányú kezdeményezés, de az sem működik aktívan. A klaszterek nemzetközi kapcsolatait illetően, a vizsgált együttműködések több mint fele, jellemzően az akkreditált klaszterek, az elmúlt években komoly erőfeszítéseket tett a nemzetközi, föként európai (német, francia, olasz) példák megismerésére, illetve, hogy előmozdítsa a klaszter ismertségét és a megfelelö kapcsolatrendszer kialakítását nemzetközi szinten. 6 klaszter kizárólag a klasztertagok révén rendelkezik külföldi kapcsolatokkal és azok kevésbé érvényesülnek klaszterszinten, míg két esetben egyáltalán nincs semmilyen nemzetközi szintű kapcsolat.

A klasztermenedzsment tevékenységének fejlesztési irányai közül a tapasztalatcsere előremozdítását, a különböző képzési tevékenységeket, képzési központ létrehozását, a szolgáltató klaszterré válást, továbbá klasztermenedzsment sales jellegü tevékenységeinek erősítését jelölték meg célként az interjúalanyok. 
Arra kérdésre, hogy mennyire tudtak szintet lépni a klaszteren belüli együttmüködések során és mi volt a legfontosabb lépcsőfok a fejlődésükben, elég hasonló válaszokat kaptam.

Azok a klaszterek, akik rendelkeznek akkreditációval kivétel nélkül egy fontos fejlődési fázisként élték meg ezen minősítés megszerzését. Talán azért is, mert az akkreditációs pályázatban a klasztereknek részletesen be kell mutatniuk az eddigi $\mathrm{K}+\mathrm{F}$ tevékenységeiket és az ezzel kapcsolatos közös céljaikat, valamint az akkreditációval rendelkező együttműködések jelentős $\mathrm{K}+\mathrm{F}$ forrásokat tudtak elnyerni a 2007-2013-as támogatási időszakban. A megkérdezett klaszterek közül hárman rendelkeznek továbbá az Európai Kiválósági Program minősítésével (egy bronz, egy ezüst és egy arany címkével) és ezt jelentős előrelépésként élték meg a klaszter életében. A fokozat amellett, hogy a klasztermenedzsment munkáját értékeli, nemzetközi szinten is jelentős ismertséget ad a klaszternek.

Azon klaszterek, melyek még nem rendelkeznek akkreditációval, azok is fontos lépésnek tartják a klaszterek életében és jövőbeni céljaik között szerepel az akkreditációra való felkészülés, mely szisztematikus, célzott közös munkát igényel a részükröl.

A klaszter fejlödése szempontjából több interjúalany is kiemelte a sikeres közös kutatási projekteket, mint a klaszter életének fontos mérföldköveit. Az egyikük a következőképpen fogalmazott. ,... 2008-ban néhány tag lazább együttmüködéseként indult majd a 2008-as nagyobb bövülés után 2008 és 2012 között nagy közös projektek valósultak meg, melyek eredményei már termékként a piacon vannak”. (8.)

A klaszterszervezetek fejlődését, átalakulását tekintve a klaszterek világos, jól megfogalmazott jövöképpel rendelkeznek, közös kutatás-fejlesztési és innovációs projekteket terveznek, nemzetközi szinten láthatóvá kívánnak válni a nemzetközi projektet megvalósítása és a nemzetközi piacokra való kilépés érdekében. Több klaszter megfogalmazta célként az interszektoriális és klaszterközi együttmüködések javítását is a versenyképességük javítása érdekében.

Hipotézis 4. A Dél-alföldi Régióban létrejött klaszterek egy részének sikerült stabil pénzügyi és szakmai növekedési pályára lépniük, így a jövőben önfenntartóvá válhat a tevékenységük.

A régiós klaszterek körében folytatott elemzés alapján megállapíthatjuk, hogy a régióban müködő klaszterek, még viszonylag nagy arányban finanszírozzák a müködésüket a külső támogatások, pályázati források segítségével és jelenleg még nem találták meg azokat a piaci bevételi lehetőségeket, amelyekből a közös tevékenységeket hosszútávon fedezni tudják. Az elmúlt néhány évben a klasztervezetök egy része már felismerte, hogy hosszú távon csak akkor lesznek sikeresek, ha piaci alapokon és önállóan is képesek müködni, és ha a tagok számára az együttmüködésből származó előnyök már jóval meghaladják a ráfordítások mértékét. Az eredményesség nagyban múlhat továbbá azon, hogy sikerül-e megteremteni azokat a bevételi forrásokat, amiböl finanszírozni tudják a közös tevékenységek koordinációját. A klasztermenedzsmentnek ennek érdekében sokkal nagyobb hangsúlyt kell fektetnie a pályázati támogatások kiváltására, a piaci alapon szervezett szolgáltatásokból származó bevételekkel. Ez a folyamat azonban még a 2014-2020-as programozási időszak végezetével is csak részben valósult meg és az elkövetkező években fog eldőlni, hogy valóban sikerül-e ezeket a feltételeket megteremteni.

Az országosan és a régióban kialakult klaszterek szakmai fenntarthatóságát is az teremtheti meg, ha képesek lesznek növekedni és a szereplők számára kölcsönös előnyökkel járó magas hozzáadott értékü, akár ágazatközi és nemzetközi szintü együttmüködéseket generálni.

A nemzeti klaszterfejlesztési politikának is ezekre a területekre szükséges fókuszálnia a jövőben is, tehát segíteni a klasztereket, hogy pénzügyileg is önálló lábakra álljanak és az úgynevezett nem pénzügyi ösztönzők révén megtanítani öket erre az üzleti szemléletre a 
célzott támogatás helyett, továbbá támogatni őket a nemzetközi piacokon való érvényesülésben és az ágazatközi együttmüködések megszervezésében.

Ezek alapján a 4. hipotézist nem sikerült alátámasztani, mivel a Dél-alföldi Régióban létrejött nagyszámú klaszterek csak egy nagyon kis százalékának sikerült olyan stabil pénzügyi és szakmai növekedési pályára lépnie, hogy a jövőben önfenntartóvá váljon a tevékenysége. A létrejött klaszterek nagy része a külső támogatások és források nélkül valószínüleg megszünik, vagy csak nagyon korlátozottan tud müködni. 


\section{A SZOFTVERIPARI INNOVÁCIÓS PÓLUS KLASZTER SIKERESSÉGÉNEK ELEMZÉSE}

Az alábbi fejezetben esettanulmány jelleggel a dolgozatom elején megfogalmazott hipotézisek teljesülését vizsgáltam egy konkrét dél-alföldi klaszter példáján keresztül, annak érdekében, hogy mélyebben be tudjam mutatni a klaszterek sikeressége mögött rejlö, összefüggéseket, motivációkat, problémákat és egyfajta ,jó gyakorlatként” kerüljön bemutatásra más klaszterek vagy a klaszterekkel foglalkozó személyek, szervezetek számára.

Egy előzetesen felállított szempontrendszer alapján a Szoftveripari Innovációs Pólus Klasztert választottam ki, melynek müködése, több, mint 10 éves múltra tekint vissza, erős kötődése van a régióhoz és a Szegedi Tudományegyetemhez, valamint számos az iparág szempontjából meghatározó kis- és középvállalkozást foglal magában. Tevékenysége kellően innovatív és a vezetése újító szemlélettel igyekszik a legújabb nemzetközi irányoknak megfelelően segíteni a klaszter müködését. Ezek alapján jó példának ítéltem meg ahhoz, hogy a hipotézisek mentén részletesebben megvizsgáljam a klaszter tevékenyégét és jövőbeni lehetőségeit.

A Szoftveripari Innovációs Pólus Klaszter (továbbiakban klaszter) a legfontosabb szoftveripari szereplök, vállalatok kutatóközpontok és technológiai transzfer szervezetek összefogásával, 2007-ben jött létre a korábbi e-Szeged konzorcium működésére és a Szegedi Tudományegyetem ipari partneri együttmüködéseire építve. A klaszter a szoftveriparban müködő kis- és középvállalkozások kompetenciáinak és az egyetem képzési és kutatási hátterének egyesítése és hatékony felhasználása révén igyekszik nem csak a tagjai versenyképességét növelni, de az iparág erősödéséhez is hozzájárulni a régióban. (PORTA NOVUM NONPROFIT KFT., 2018).

Az esettanulmányt három félig struktúrált interjú és a klaszter legfontosabb fejlesztési dokumentumainak, alapító okiratának, szervezeti és müködési szabályzatának és cselekvési tervének elemzése alapján készítettem el 2018 decemberében.

Az első interjúalanyom Gortva-Kónya Mónika volt, aki a Szoftveripari Innovációs Pólus Klaszter menedzsere, aki 2011 óta vesz részt a klaszter menedzsment tevékenységében, így már kellő tapasztalattal és információval rendelkezik az együttmüködések hátterét illetően.

Mivel a klaszter a Szegedi Tudományegyetem (SZTE) tudásbázisára épülve alakult ki és folytatja tevékenységét, továbbá az innovatív klaszterek müködése során számos esetben kiemelkedő szerepe van a kutatási intézményeknek, egyetemeknek, így az SZTE klaszterekért felelős egységének igazgatóját is megkérdeztem a klaszteres együttmüködés hátteréröl, tapasztalatairól. Pitó Enikő 2014 óta a Szegedi Tudományegyetem Kutatás Fejlesztési és Innovációs Igazgatóságának vezetője. Az Igazgatóság feladatai közé tartozik többek között az SZTE részvételével és tudásbázisára épülő klaszterekkel való együttmüködések kezelése és az egyetem ipari kapcsolatainak menedzsmentje. Az egyetem összességében 23 klaszter müködésében vállalt szerepet, melyböl 21 dél-alföldi székhelyü kezdeményezés.

Harmadik interjúalanyként a nemzeti klaszterfejlesztési programok és támogatások egyik kiemelkedő szereplöjével, Keller Péterrel a Pénzügyminisztérium főosztályvezetőhelyettesével készítettem interjút, aki már több éve részt vesz a klasztertámogatási rendszerek és források koordinációjában és értékelésében. Ennek megfelelően ő szabályozói és támogatói oldalról osztotta meg a tapasztalatait, a magyarországi és szükebb értelemben a Dél-alföldi Régió klasztereire és konkrétan a Szoftveripari Innovációs Pólus Klaszterre vonatkozóan.

Keller Péter a Pénzügyminisztérium, Gazdaságfejlesztési Programok Irányító Hatóságán (Gazdaságfejlesztési Programok Végrehajtásáért felelős Helyettes Államtitkárság - GFP HÁT) belül müködő Nemzetközi és Klaszter Osztály főosztályvezető-helyettese. Az Iroda a 
Pólus Program Iroda és a MAG Zrt Klaszterfejlesztési Iroda utódjaként, több mint 8 éve vesz részt a hazai klaszterek támogatásában az alábbi tevékenységekkel: ${ }^{23}$

- A hazai klaszterfejlesztési programok és pályázati konstrukciók kialakításában és utólagos értékelésében való részvétel.

- A klaszter akkreditációs eljárások és a kapcsolódó pályázat menedzsmentje

- Elemzések, adatbázisok, tanulmányok készítése többek között a klaszterek pályázati aktivitásáról, gazdasági teljesítményéről.

- Nemzetközi klaszteres projektekben és a nemzetközi klaszteres munkacsoportokban való részvétel és érdekképviselet.

- Kapcsolattartás a hazai és nemzetközi klaszterekkel, klaszterek közötti együttmüködések ösztönzése és a klaszterek tájékoztatása a kormányzati fejlesztéspolitikáról és a támogatási lehetőségekről

\subsection{Az alapvető ,sikerkritériumok” érvényesülése a klaszterben}

A klaszter összetételét és méretét tekintve a szoftveriparban tevékenykedő profitorientált és nonprofit szervezeteket tömöríti magában, jelenleg 35 rendes és 5 pártoló tagja van. A tagok között 32 kis- és középvállalkozás, 1 egyéb vállalkozás és 2 egyetem (a Pécsi Tudományegyetem és a Debreceni Egyetem) található, míg pártoló tagok a Szegedi Tudományegyetem, a Bács-Kiskun Megyei Kereskedelmi és Iparkamara és 3 további vállalkozás. Nagyvállalat már nem tagja a klaszternek, mivel ebben az iparágban nagy szerepe van a kis-és közepes vállalkozásoknak, másrészröl a nagyvállalatok nehezebben kezelhetőek a klaszteren belül, hiszen a döntéshozataluk lassú és hierarchikus és a vállalatok kutatásfejlesztési központja is inkább az anyacégeknél található. A tagok tevékenysége lefedi a teljes szoftveripari innovációs értékláncot: a kutatás-fejlesztéstől, illetve a technológia- és szoftverfejlesztéstől a rendszerbevezetésen és integráción, illetve eszközgyártáson át az értékesítésig, kapcsolódó felsőoktatásig és felnőttképzésig, illetve informatikai és vezetési tanácsadásig.

A klaszter összetételét tekintve megfelelőnek mondható, bár a klasztertagok száma nem haladja meg az átlagot és nem növekedett túl sokat az elmúlt években. Ha a régióban müködő szoftveripari vállalkozásokat számát tekintjük, mely jelenleg közel 1000 céget $^{24}$ jelent, a klaszter 3,5\%-os részesedésével még korántsem érte el az úgynevezett kritikus tömeget. A klasztermenedzser véleménye szerint azonban a jelenlegi taglétszám az a nagyságrend, amely még kezelhető számukra, bővítést inkább csak új fejlesztési irányok mentén tudnak elképzelni, annak érdekében, hogy bevonják a legújabb infokommunikációs technológiai trendek releváns képviselöit. Erre vonatkozóan persze vannak már elképzeléseik.

A bizalom kérdése egy nagyon fontos, de nehezen mérhető faktor a klaszteren belül. A klaszteren belüli bizalmat egymás megismerésén és a klasztertalálkozókon túl leginkább a sikeresen lebonyolított közös projektek tudják erősíteni. A bizalom meglétét, tehát ezen projektek nagy száma (több, mint 80 ) és a klaszteren belül létrehozott 3 projektcég megléte is mutatja. A bizalom magas fokát igazolja, hogy az egyes tagok már nem csak az információkat és a tudásukat osztják meg egymással, de közös kockázatokat és felelősséget is mernek vállalni egy projektcég keretein belül. Egy új kezdeményezés is indult továbbá a klaszteren belül a klasztermenedzsment szervezet koordinálásában, mely az egymás közötti munkaerő megosztást és munkaerő kölcsönzést támogatná, hiszen az informatikai vállalatok sokszor

\footnotetext{
${ }^{23}$ http://www.klaszterfejlesztes.hu/content.php?cid=cont_4ffc4e93a46377.36499107

${ }^{24}$ Opten adatbázis alapján, a 6201, 6202, 6203 és 6209-es TEÁOR számú főtevékenységgel rendelkező vállalkozások száma 2019. szeptemberében.
} 
kapnak olyan időszakos megbízásokat, melyhez hirtelen nagy mennyiségü, tapasztalt munkaerőre, fejlesztőre lenne szükségük. Erre nyújthat megoldást ez a szolgáltatás, mely szintén erős bizalmi viszonyokat feltételez, hiszen a jó munkaerö ebben az iparágban is nagyon nagy értéknek számít. Ezen a területen a klasztermenedzser véleménye szerint azonban még mindig fejlődni kell a klaszternek.

Az SZTE Innovációs Igazgatója szerint a bizalom a kutatások területén kiemelkedően fontos kritérium, hiszen egy közös kutatás-fejlesztési projekt során mindenki a legféltettebb kincsét a tudását osztja meg és a projekt eredményeképpen nagyon fontos szellemi termékek keletkeznek, melyeket védeni, esetleg titokban tartani szükséges. Ráadásul sok esetben nagyon nagy összegü fejlesztésekröl van szó, amelyet nagyon kockázatos lenne olyan partnerrel megvalósítani, akit nem ismerünk teljes mértékben vagy nem bízunk meg maximálisan benne.

A földrajzi koncentráció kevésbé meghatározó a klaszteren belül, ugyan a tagvállalatok nagyobb részének a Dél-alföldi Régióban és azon belül is jellemzően Szegeden van a székhelye, azonban van számos régión kívüli tag is. A klasztermenedzser megítélése szerint ezen a szakterületen talán kisebb a jelentősége a földrajzi koncentrációnak. A tagok között meglévő távolságok az infokommunikációs technológiák segítségével viszonylag könnyen áthidalhatóak fóként Magyarországot tekintve.

A klaszter teljes mértékben épít a lokális előnyökre. A klaszter székhelye Szegeden található és számos klasztertag tevékenyégének központját is ez a város adja. A városba az elmúlt években egyre több informatikai cég települt be, így dinamikusan növekszik mind az IT cégek, mind a munkavállalók száma. Jó az együttmüködés a Szegedi Tudományegyetemmel és a Bács-Kiskun Megyei Kereskedelmi és Iparkamarával, hiszen mindkét szervezet pártoló tagja a klaszternek. Ezen kívül az önkormányzattal is szoros együttmüködésben és kommunikációban dolgozik a klaszter, számos informatikai témájú felmérésben, tanulmányban és projektben épített az önkormányzat a klaszter háttértudására, információira.

A klaszter 2008 óta jól megfogalmazott, rendszeresen felülvizsgált közös célokkal, fejlesztési stratégiával és cselekvési tervvel rendelkezik, melyek a klasztertagok véleménye és tevékenysége alapján folyamatosan frissülnek és kiegészülnek. A klasztermenedzsment igyekszik a legújabb szakmai trendeket, fejlesztési irányokat is figyelemmel kísérni és beépíteni a közös célok és tevékenységek közé.

A klaszter tagjai az elmúlt 10 évben, több mint 80 üzleti együttmüködés és kutatásfejlesztési projektet valósítottak meg, melyek értéke meghaladja a 6,5 milliárd forintot. A közös projektek a klasztertagok technológiai és piaci tudásának átadására és egymás közötti megosztására irányultak, melyek hatással vannak a tudásbázis kölcsönös növekedésére és a szereplők müködésének hatékonyságára.

Az együttmúködések nagyon változatos formákban és területeken valósultak meg, úgy mint például közös projektcégek alapítása, szektor specifikus alkalmazások fejlesztése, rendszertervezés, szoftverfejlesztés, szoftverkövetés, egységes szoftverminőség-biztosítási platform kialakítása és üzleti alkalmazások fejlesztése, IT szolgáltatások nyújtása, szakértői és oktatási tevékenységek... stb.. A klasztertagok együttmüködéséből 3 féle közös termék, illetve szolgáltatás is létrejött, köztük a Refactoring keretrendszer és a szektor specifikus SCM (Supply Chain Management) alkalmazások létrehozása, továbbá a szoftverminőségbiztosítási platform kialakítása.

Egy a közelmúltban megvalósult nemzetközi kiállításon való megjelenés megszervezését és kialakítását is az együttmüködés jó példájaként említette a klasztermenedzser, mivel a 
kiállításon egy mezőgazdasági gépekkel foglalkozó cég megjelenését sikerült a legújabb VR (virtuális valóság) technológiák alkalmazásával és a kapcsolódó professzionális kiadvánnyal nemzetközi szinten is kiemelkedővé és érdekessé tenni, úgy hogy minden cég azzal járult hozzá a megjelenéshez, amihez igazán értett, a klasztermenedzsment pedig összehangolta azt. Ennél a projektnél már kifejezetten érvényesült az ágazatok közötti kooperációk pozitív hatása.

A klaszter menedzsment feladatait 2017.12.31-ig a DEAK Zrt., majd a DEAK Zrt-ben történt változások miatt, 2018. január 1-től a Porta Novum Nonprofit Kft. végzi. A menedzsment személyi hátterében ez azonban nem okozott változást, így jelenleg is a klasztert jól ismerő, komoly partnerség építési és üzletfejlesztési tapasztalattal rendelkező munkatársak végzik a klasztermenedzsment tevékenységeket. A Porta Novum Nonprofit Kft. nem klasztertag és a klasztertagoktól teljesen független szervezet. A Nonprofit Kft. ügyvezetője mellett, 2 projektmenedzser látják el az operatív teendőket és végzik az egyes projektek előkészítését és koordinálását.

A menedzsment szervezet széles körü kompetenciákkal és többéves szakmai háttérrel rendelkezik a nagy volumenü hazai és Európai Uniós finanszírozású projektek megvalósításában, infokommunikációs területeken és egyéb iparágak közötti, egyetemi, önkormányzati és vállalati együttmüködések erösítésében, képzések szervezésében és lebonyolításában. A szervezet céljai között szerepel a széleskörü hazai és nemzetközi IT együttmüködések kialakítása a fejlesztések, a képzés, valamint a HR területén.

A hatékony klaszteren belüli és klaszteren kívüli együttmüködések kialakítását a szervezet az alábbi tevékenységekkel is igyekezett elömozdítani az elmúlt években:

- benchmarking klub sorozat

- üzleti meetup rendezvény sorozat

- projektgenerálásra irányuló tematikus programok

- nemzetközi matchmaking rendezvények

- Tech Trend Show Szeged

- hírleveles és e-mailes tájékoztatás

- elégedettség mérés a klasztertagok körében (mélyinterjúkkal, kérdőívvel)

A klasztermenedzsment szervezet elnyerte a European Secreteriat for Cluster Analysis (ESCA) nemzetközi szervezet „Cluster Management Excellence” ezüst fokozatú minősítését, mely egy komoly nemzetközi elismerés és hírnév nem csak a menedzsment szervezet, de a teljes klaszter számára.

Keller Péter véleménye szerint a kritikus tömeg, mint sikertényező szerepe nagyon fontos a hazai klaszterek esetében. Az ő megítélése szerint a 80 feletti az a taglétszámú klaszter, ami eléri a kritikus tömeget. Legalább ekkora klaszterekre lenne szükség. Ekkora taglétszámnak a kezelése részben klaszter menedzsment kérdés is, hiszen 1-2 fövel 30-40 tag menedzselhetö, de 3-4 fővel már a 80-100 tagú klaszter is kezelhető. Ennél nagyobb már valóban nehezen irányítható. Fontosak a helyi térségi előnyökre épülő kisebb méretü klaszterek, de egyre inkább az országos nagyságrendủ klaszterek támogatása az irány. A földrajzi koncentráció fontos ugyan a siker szempontjából, de Magyarország területe nem olyan nagy, hogy ez hazai szinten releváns lenne. Az akkreditált klasztereket tekintve 7 informatikai klaszter van jelenleg, mely 250 tagot tömörít magába. Ebböl nagyjából 150 az elkötelezett tag, így ez alapján 2 jól müködö klaszter is elegendő lenne. Jelenleg a 7 klaszter nagyjából a 7 regionális központban található. Ezen szempontok alapján sajnos nem túl sok olyan klaszter van, aki megfelel a felsorolt sikerkritériumoknak, nagyjából 10 alatti ezen klaszterek száma. Az utolsó 2 tényező, ami leginkább gyenge a klaszterek esetében. Az összetételük megfelelő a legfontosabb szereplők a piacilag fontos és erős cégek, kutatóhelyek, támogató 
önkormányzatok megvannak a klaszterekben, de nem hatékony az együttmüködés vagy hiányzik a profi klasztermenedzsment. Ezért nem is tudtak eddig sikeresek lenni a magyarországi klaszterek nemzetközi szinten, mert nem feleltek meg ezeknek a sikertényezőknek. Elmondása szerint a Szoftveripari Innovációs Pólus Klaszter abba a néhány klaszterbe tartozik bele, amelyet sikeresnek tekinthetünk, és amelynek a fenti feltételek alapján megvan az esélye a hosszú távú sikeres müködésre.

\subsection{A Szoftveripari Innovációs Pólus Klaszter hozzáadott értéke a klasztertagok számára}

A klaszter legnagyobb hozzáadott értéke maga a szolgáltatási portfólió, amely segítségével minden olyan ponton segíteni tud a klaszter a tagok számára, ahol szűk keresztmetszeteik vannak. A klaszter célja egyfajta „szolgáltató klaszterré” válni, melyet az alábbi szolgáltatásokkal kívánnak elérni:

- $\mathrm{Az}$ alapdokumentumok (stratégiák, cselekvési terv) elkészítése, ügyviteli és koordinációs feladatok ellátása

- Felmérések, adatbázisok készítése

- Marketing és kommunikációs tevékenységek

- Különböző klaszteres és szakmai rendezvények szervezése

- Szakmai érdekvédelmi szervezetekkel való együttmüködések kialakítása

- A klasztertagok igényein alapuló képzések kialakítása

- Tagok közötti együttműködések elösegítése, projektgenerálás, közös projektek előkészítése

- Hazai és nemzetközi partnerkeresés, kooperációs lehetőségek felkutatása

- Nemzetközi kapcsolatépítési tevékenység, nemzetközi hálózatokban való részvétel erösítése

- Hazai és nemzetközi pályázati és lobbi tevékenység

A klasztermenedzsment igyekszik olyan szolgáltatásokat kínálni a tagok számára, amelyek valódi piaci értéket képeznek a számukra. Mint újfajta szolgáltatás elindult egyfajta toborzási, képzési tevékenység is, hiszen a menedzsment felismerte, hogy ebben az iparágban most az egyik legnagyobb problémát a munkaerőhiány jelenti a szereplők számára. A cégek sokszor nem találnak megfelelő informatikai szakembert a pozíciójukra, a belső képzések pedig viszonylag költségesek és időigényesek. Ezek alapján a klaszter menedzsment piaci igényekre alapuló szektor specifikus moduláris felnőttképzéseket indít, gyakornoki programot szervez továbbá IT szakemberek toborzásában, projektalapú teamek szervezésében, munkaerő kölcsönzésben és kiajánlásában müködik közre.

A képzéseken kívül igyekeznek a nemzetközi együttmüködések kialakítására is nagyobb hangsúly fektetetni. A jelenleg futó GINOP pályázati projekt is a minőségi klasztermenedzsment szolgáltatások kialakítására és a nemzetközi piacra jutás előmozdítására irányul. A projekt keretében 4 nemzetközi klaszteres konferencia (pl. Tech Trend show) kerül megrendezésre, ahol a legújabb szakmai trendekkel, irányokkal ismerkedhetnek meg a klasztertagok, ezzel is ösztönözve őket az újításra, innovációra. Ezen kívül különböző nemzetközi szakmai konferenciákra, kiállításokra viszik ki a klasztertagokat a nemzetközi kapcsolatteremtés érdekében, mivel úgy érzik a klasztertagok és a klaszter nemzetközi „láthatóságának” növelése a klasztermenedzsment egyik fontos feladata. 
Az egyetem számára a klaszter az ipari kapcsolatok tekintetében nagyon fontos, hiszen a klaszterek segítségével nagyszámú, a tevékenységük szempontjából fontos vállalkozást tudnak elérni és megismerni az igényeiket, megtalálni az együttmüködési lehetőségeket. Az ezzel kapcsolatos szolgáltatások képviselik az SZTE számára a legnagyobb hozzáadott értéket, tehát a klasztertagok fejlesztési igényeinek feltárása és közvetítése, valamint a kapcsolódó projektgenerálás. Az egyetem a képzési, oktatási tevékenységén túl a kutatásfejlesztési hátterével, kutatói szakembergárdájával, kutatási infrastruktúrájával tudja a klasztert erősíteni. Egyfajta inkubációs környezetet biztosít a klasztertagok részéről felmerült ötletek megvalósításához. Az Igazgatóság ezen felül a közösen létrehozott szellemi termékek védelmében és üzleti hasznosításában tud még közremúködni az egyetem részéröl. $\mathrm{A} \mathrm{K}+\mathrm{F}$ eredmények piaci hasznosítása pedig nagyon fontos terület mind az egyetem, mind a vállalkozások számára.

Támogatói oldalról (Keller Péter véleménye szerint) a legtöbb menedzsment szervezet, azért nem tekinthető professzionálisnak, mert kizárólag az állami, vagy az egyéb külső támogatásokat várják és nem lépnek fel önállóan, nem fejlesztenek ki olyan szolgáltatásokat, amelyeket a piacon lehetne értékesíteni. A klasztertámogatási rendszerben volt 3-4 év szünet, egyfajta forrásínség, mivel az utolsó támogatások 2014-ig lezárultak és csak 2017-2018-ban kerültek újabb pályázatok kiírásra. Arra vonatkozóan, hogy hogyan vészelték át ezt az időszakot a klaszterek, többféle példa alakult ki. Voltak, akik elhaltak, voltak, akik valamely erős nagyvállalat, támogató szerv, kamara vagy egyetem támogatásaiból éltek meg, és csak nagyon kevesen voltak olyanok, akik piacképes szolgáltatásokat fejlesztettek a tagok felé vagy nemzetközi színtéren elkezdték megmérettetni magukat. Hiányzik, hogy legyen olyan profi menedzsment szerv, aki nem csak a munkaidején túl, hanem fóállásban dolgozik a menedzsmentben, beszél angolul és ezáltal képes nemzetközi pályázatokban részt venni, továbbá fel tudja mérni, hogy mire van szüksége a tagoknak.

Az informatikai klasztereket tekintve az Észak-Magyarországi Informatikai Klaszter és a Szoftveripari Innovációs Pólus Klaszter is jó példa, hiszen felmérték, hogy a legnagyobb probléma a szakemberhiány és elkezdtek ilyen irányú képzéseket szervezni. Vannak olyan szolgáltatások, ahol van lehetősége a menedzsmentnek is, ilyenek például az. inkubációs szolgáltatások, munkaerő képzés, nemzetközi kapcsolatok, nemzetközi pályázatok.

Arra vonatkozóan, hogy mivel tudja a Pénzügyminisztérium ezt segíteni, a jelenlegi GINOP pályázatokban 2 irány van. Egyrészről az önfenntartó klasztermenedzsment támogatása, hogy legyen 1-2 fóállású dedikált szakember, aki csak ezzel foglalkozik. Másik témakör pedig a nemzetközi piacra lépés. A költségek minimum 40\%-át arra kell fordítaniuk a nyertes klasztermenedzsment szervezeteknek, hogy részt vegyenek különböző B2B konferenciákon, találkozókon, releváns nemzetközi piackutatásokat rendeljenek meg. Az üzlet a tagvállalatok között alakul ki így fontos, hogy ök is menjenek, ne csak a menedzserek és nyissanak a lehetséges külföldi partnerek felé. A nemzetközi partnerek azonban sajnos általában nem nagyon tudnak mit kezdeni a 30-40 föt tartalmazó klaszterekkel, persze erre vonatkozóan is van kivétel például a bolgár bútoripari klaszter sikere.

\section{3. $\quad K+F+I$ tevékenységek, tudásátadás a klaszteren belül}

A klaszter stratégiájának egyik fontos eleme a Szegedi Tudományegyetem által biztosított kutatási, fejlesztési eredmények átadása a klaszter piaci szereplői számára. Számos olyan $\mathrm{K}+\mathrm{F}$ projekt került megvalósításra, amelyben az egyetem kutatói, spin-off vállalkozásai és a klasztercégek szakértői közösen dolgoztak, így a technológiai transzfer és a cégek tudásbázisának növekedése a lehető leghatékonyabban a gyakorlatban valósulhatott meg. A tudásátadás másik eleme az egyetem oktatási bázisára, kompetenciájára épül, hiszen az 
egyetem számos olyan képzéssel rendelkezik, amely hozzájárul a klasztertagok elméleti tudásának bővítéséhez, és amelyet a fejlesztési tevékenységük során is tudnak alkalmazni.

Mivel a tagvállalatok különböző információtechnológiai területeken dolgoznak, ezért a klaszter-együttmüködés keretében nagyon fontos szerepe van a klasztertagok közötti tudás átadásnak is. Ennek legfontosabb megvalósulása a közös projektekben történő részvétel. A közös projektekben a tagok egymás piaci kapcsolatait is kölcsönösen ki tudják használni, ezzel is elősegítve az európai piacon történő megjelenést.

A klaszter kulcsterületeinek kiválasztása során fontos szempont volt, hogy olyan területeket célozzanak meg, amelyek a jelenlegi informatikai és szoftveres trendek leginnovatívabb területei és amelyek jelentős nemzetközi piaci potenciállal rendelkeznek. Az üzleti lehetőségeket, az innovációt, valamint a klaszteren belüli kompetenciákat figyelembe véve a klaszter fö $\mathrm{K}+\mathrm{F}$ kompetenciái az alábbi 26. ábrán bemutatott témakörök mentén csoportosíthatóak:

\section{6. ábra A Szoftveripari Innovációs Pólus Klaszter fó fejlesztési területei}

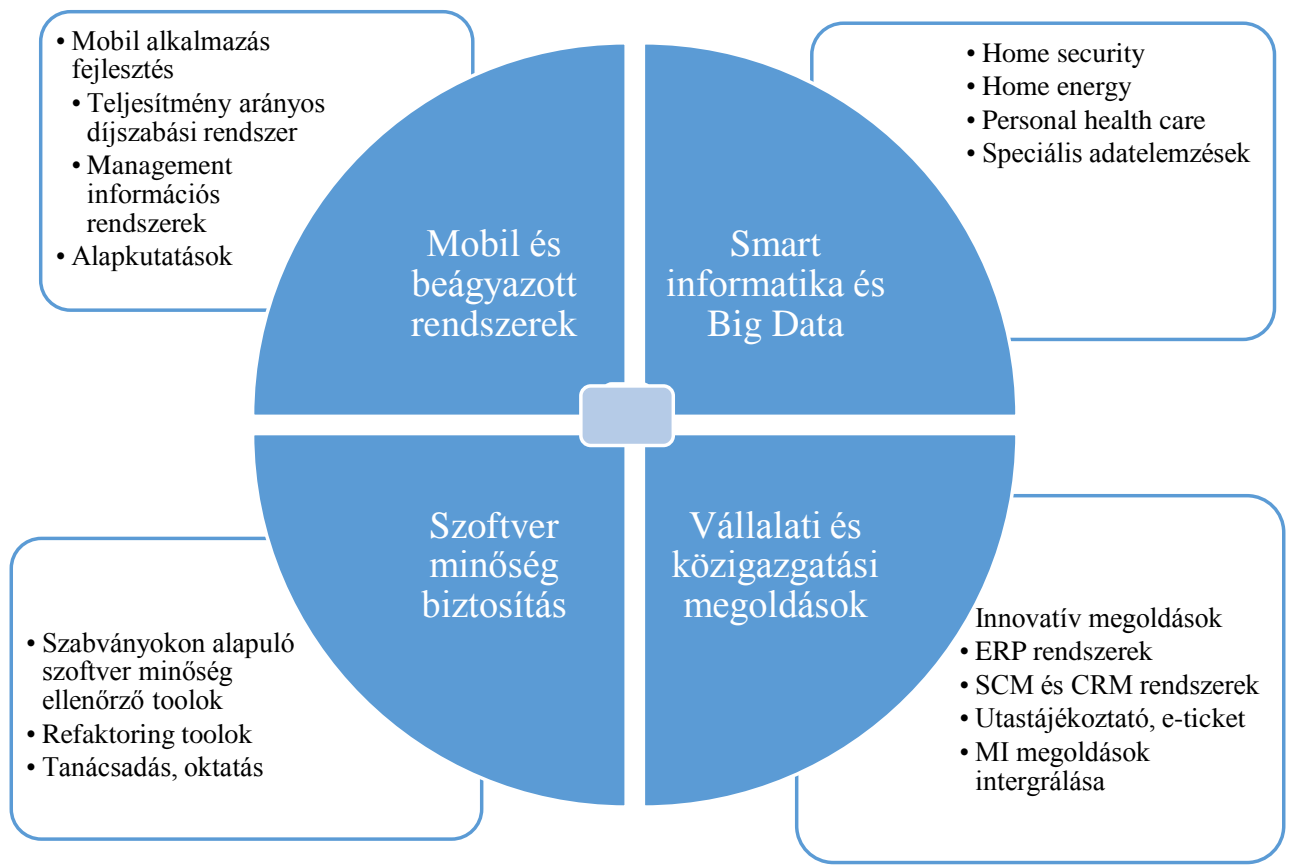

Forrás: A Szoftveripari Innovációs Pólus Klaszter Cselekvési Terve alapján saját szerkesztés

A klaszter és a klasztertagok innovativitását mutatja az a tény is, hogy a klaszter 2008 óta rendelkezik a leginnovatívabb klasztereknek járó Akkreditált klaszter címmel, melyet rendszeresen sikeresen meg is újít.

A klasztertagok számos találmánnyal rendelkeznek, melyek közül 15 szabadalom és védjegy közvetlenül kötődik a klaszter szempontjából releváns szakterületekhez.

A klasztermenedzser véleménye szerint az innováció fontos terület a klasztertagok nagy részénél, nem csak a cégek, de a munkavállalók szempontjából is, hogy meglegyen a fejlődési lehetőségük és ne váltsanak túl gyorsan munkahelyet. A cégeknek gazdaságilag és szakmailag is meg kell érniük az innovációra és a nemzetközi piacra lépésre egyaránt.

Az SZTE és a klasztertagok között az Informatikai Tanszékcsoport, ezen belül a Szoftverfejlesztési Tanszék és néhány egyéb tanszék révén számos közös kutatás-fejlesztési projekt folyik. A klaszterekkel való tudásmegosztás és közös $\mathrm{K}+\mathrm{F}$ területén azonban még van mit fejleszteni, de ehhez még inkább meg kell ismernie az egyetemnek a tagvállalatok kutatási területeit és problémáit, illetve nekik is tudniuk kell, hogy milyen $\mathrm{K}+\mathrm{F}$ kérdésekkel hova forduljanak az egyetemen belül. Az Innovációs Igazgatóság egyfajta ipari kapcsolati „egy 
ablakként" igyekszik megtalálni a legmegfelelöbb belső egyetemi partnert vagy kutatói csapatot egy konkrét kutatás-fejlesztési megkeresés vagy probléma esetében. Az ilyen jellegü igények közvetítésében lehet nagy szerepe a klasztermenedzsment szervezetnek.

Keller Péter is úgy véli, a klaszter nem működhet oktatási és kutatási szervezetek nélkül és fontos, hogy benne legyenek az egyetemek, melyek egyik legfontosabb szerepe, hogy infrastruktúrát és erőforrásokat biztosítsanak az innovatív kezdő start-up cégeknek, egyfajta inkubációs, innovációs központként lépjenek fel. A képzésben is óriási a felelősségük, mivel a korábbiakhoz képest rugalmasabban kell reagálniuk a megváltozott igényekre, valamint az egyetemek úgynevezett harmadik missziós tevékenységei is fontosak a klaszterek gazdaságfejlesztési és üzletfejlesztési eredményeinek szempontjából. A K+F tevékenységeket tekintve a klaszterek fontos szereplők, mivel a 2007-2013-as időszak pályázataira vonatkozó felmérésböl is megmutatkozott, hogy a $\mathrm{K}+\mathrm{F}$ projektekben a klasztertagok sokkal megbízhatóbbak voltak, hiszen az együttmüködésnek már megvan a stabil háttere. Azt persze nehéz megállapítani, hogy a cégek azért innovatívak, mert klasztertagok, vagy a klaszterek a legerősebb, leginnovatívabb cégeket vonják be, hiszen most nagyon erős minőségi szürőt alkalmaznak a tagokra vonatkozóan.

\subsection{A klaszter pénzügyi és szakmai fenntarthatósága, jövőbeni célok, nemzetközi trendek}

A Klaszter tevékenysége során folyamatosan felülvizsgálja stratégiai céljait a piaci szereplők pozícióinak és a technológiai trendeknek megfelelően. A szoftverminőség biztosítás területén további szolgáltatásokkal kívánják bővíteni a portfóliót annak érdekében, hogy lefedjék a teljes szoftver-életciklus folyamatát. A Smart informatika és Big data terület legjelentősebb célja az, hogy a már meglévő informatikai rendszerek magas szinten tudják alkalmazni ennek a fókuszterületnek az előnyeit. A mobil és beágyazott rendszerek és cloud computing fókuszterület jövőbeni célja pedig az SZTE kutatási, tudományos hátterére alapozva egyedi, hatékony megoldások kifejlesztése és olyan speciális „niche” piaci szegmensek megcélzása, mint például a személyre szabott telemedicina.

A klasztermenedzsment szervezet is igyekszik folyamatosan megújulni és alkalmazkodni azokhoz a szakmai és pénzügyi kihívásokhoz, amelyekkel a klaszterek szembesülnek. A tevékenységüket folyamatosan bővítik annak érdekében, hogy minél inkább a piaci igényeknek megfelelő szolgáltatási portfólióval rendelkezzenek. A szolgáltatásival a szervezet már nem kizárólag a klasztertagokat célozza meg, hanem részt kíván venni egy úgynevezett „InfoPólus klaszter community” kialakításában, melynek eredményeként számos ponton be tud kapcsolódni a közösség tagjainak életébe. A közösség magában foglalja az informatikai cégek mellett az újonnan alakult start-upokat, az ezen a területen tevékenykedő befektetőket, szakértőket és mentorokat, továbbá a jövő munkavállalóit és vállalkozóit képező diákokat. Minden szegmenst különböző szolgáltatásokkal céloznak meg, mint például a start-upoknak nyújtott mentoring, coaching, akcelerátor és kockázati tőke közvetítési tevékenység vagy a szakembereknek nyújtott kapcsolatépítési, továbbképzési és karrierlehetőségek, valamint a befektetők számára kínált piaci technológiai és üzleti értékelési szolgáltatások.

Az egyik jelenleg futó határmenti együttmüködési projekt keretében pedig egy olyan online platform és kompetencia adatbázis kerül kiépítésre, ahol a szereplők fel tudják tüntetni, hogy milyen típusú szolgáltatásokat tudnak kínálni és milyen típusú szakemberre van szükségük, ezáltal is ösztönözve a partnerkeresést.

A menedzsment szervezet piaci alapokra helyezett szolgáltatási portfóliója tehát az alábbi elemeket tartalmazza:

- Képzés szervezés

- Nemzetközi együttmüködések kialakítása 
- Érdekképviselet

- Team kiajánlás

- Konferencia, kiállítás szervezés

- Közösség építés

A pénzügyi fenntarthatóságot vizsgálva a klasztermenedzsment bevételei jelenleg a pályázati támogatásokból, klasztertagdíjakból és a szolgáltatási bevételekből tevődnek össze, azonban a fenti három bevételi forrás közül még mindig a külső támogatások teszik ki a legnagyobb hányadot. A tagdíj jelenleg havi nettó $20.000 \mathrm{Ft}$ tagonként, mely egy fó klasztermenedzser bérét és az adminisztrációs költségeket fedezi. A szolgáltatási bevételek jelenleg még nagyon alacsonyak, de a klasztermenedzsment egyre inkább azon dolgozik, hogy ezek a bevételek néhány éven belül már a költségek nagy részét fedezzék. Ehhez felmérték a piaci igényeket és olyan piacképes szolgáltatási portfóliót igyekeznek kialakítani, amelyért nem csak a klasztertagok, de más informatikai területen müködő vállalkozások és egyéb szereplők is hajlandóak fizetni. Ennek megfelelően tevékenységüket is kiterjesztik és a klasztertagokon túl egy tágabb IT közösséget céloznak meg. A klasztermenedzser véleménye alapján ez az irány lehet az, amelynek köszönhetően pár év múlva már a klaszter müködése nem függ ilyen mértékben a támogatási forrásoktól, hanem képesek lesznek önfenntartó módon sikeresen müködni.

Keller Péter szerint nagyon kevés az a klaszter, aki folyamatosan figyeli a trendeket és annak megfelelően módosítja a stratégiát. A stratégia gondolkodásban még sokat kell fejlődniük, hogy elöre gondolkodjanak. A Szoftveripari Innovációs Pólus Klaszter ebben a tekintetben is jó példának tekinthető, hiszen igyekszik figyelemmel kísérni a legújabb technológiai kihívásokat. Véleménye szerint a pénzügyi fenntarthatóságot tekintve teljesen külső támogatás nélkül valószínüleg nem tudnak müködni a klaszterek, valamilyen állami támogatás szükséges a menedzsment szervezet fenntartásához. A külföldi példák is ezt mutatják. Az viszont fontos, hogy legalább a költségvetésük valamekkora részét gazdálkodják ki a szolgáltatásokkal. Sokkal nagyobb hangsúlyt kell fektetni arra, hogy azok az eredmények, amelyeket a tagok fejlesztenek ki a piacra kerüljenek és profitot generáljanak. Ez persze nem mindig jelenik meg a menedzsment szervezetnél, hiszen a cégeknél csapódik le és kérdés, hogy hogyan tud ez a menedzsment szervezetnek bevételt termelni. A 2007-2013-as K+F támogatásokból kevés volt az, ami piacorientált fejlesztés volt, és amiből később profit is származott, így ezen lenne jó változtatni a klaszterek esetében.

A nemzetközi irányokat, ágazatközi, klaszterközi együttmüködéseket tekintve az akkreditált infokommunikációs klaszterek között ugyan elindult egy fórumszerü együttműködés, de ez mára inkább csak eseti jellegü. A klaszter jó kapcsolatot ápol a többi informatikai klaszterrel, köztük kiemelten az Innoskart IKT Klaszterrel és az Északmagyarországi Informatikai Klaszterrel. Ezek az együttmüködések azonban jelenleg még kevésbé szervezettek. Az ágazatközi együttmüködésekre is egyre nagyobb hangsúlyt fektetnek a klasztervezetők, jelenleg elindult egy egyezetési folyamat a kecskeméti székhelyü autóiparhoz kapcsolódó AI3PA Smart klaszterrel és a Hírös Beszállítói Klaszterrel az együttmüködési lehetőségekről.

A klaszter kiemelten kezeli a nemzetközi kapcsolatok kezelését és a nemzetközi láthatóság növelését ennek érdekében több nemzetközi hálózathoz és platformhoz csatlakozott, mint például a CyberForum Clusterize Business Roaming Agreement nemzetközi hálózat és a European Cluster Collaboration Platform. A klasztermenedzser bevallása szerint a klaszter nemzetközi elismertségéhez és megismeréséhez nagyban hozzájárult a „Cluster Management Excellence” minősítési rendszer ezüst fokozatának megszerzése. A klaszter menedzsment igyekszik a lehető legtöbb nemzetközi klaszterrendezvényen és találkozón képviselni a klasztert és megismerni a legújabb sikeres 
gyakorlatokat, módszereket, továbbá az informatikai szakterületen is megismerni a legújabb nemzetközi irányokat, trendeket. A nemzetközi együttmüködések tekintetében a visegrádi négyek országaival való együttmüködések emelhetőek ki. A klaszter nemzetközi együttmüködési megegyezést írt alá a Visegrádi Alapnak és a Nemzetközi Klaszterhálózatnak köszönhetően a Silesian Aviation Cluster-al és a Polish Cluster Employer's Association-el. A klaszter határmenti együttmüködései is igen aktívak és sikeresek. A Magyar-Román Határon Átnyúló Együttmüködési Programnak köszönhetően 2014-ben a Szoftveripari Innovációs Pólus Klaszter és a Banat IT Association között létrejött egy együttműködés, melynek célja, hogy a program területén elősegítése az ICT vállalkozások együttmüködéseit, kereskedelmi kapcsolatait, ösztönözze a C2C, B2C, B2B nemzetközi kapcsolatokat, valamint a kutatásfejlesztés és innováció területén támogassa a kutatási programokban történő részvételt. A Magyar-Szerb Határon Átnyúló Együttmüködési Program az újvidéki Vojvodina ICT Clusterel és a Subotica ICT Cluster-el történő több területre kiterjedő együttmüködést segítette.

A nem pénzügyi ösztönzők közül a klasztermenedzser a nemzetközi megjelenésekhez nyújtott támogatásokat és a különböző matchmaking rendezvényeket tartja a leghasznosabbnak, melyeket az Európai Klaszter Együttmüködési Platformon (European Cluster Collaboration Platform) keresztül igénybe is vesz a szervezet. A platform tájékoztatást nyújt a legfrissebb klaszteres hírekről és pályázati forrásokról, segítséget nyújt a klaszterek nemzetközi megjelenéséhez, továbbá klasztertalálkozókat, képzéseket webinarokat szervez a különbözö klaszteres témákban mint például cluster branding vagy klaszteres jó gyakorlatok.

Keller Péter megítélése szerint a hazai rendszerben még nem nagyon vannak jelen a nem pénzügyi jellegü ösztönzők, inkább uniós szinten jellemzőek. A Bizottság magyar javaslatra támogatni fog egy klaszter menedzser Erasmus programot, annak érdekében, hogy a klaszteres jó gyakorlatokat ne csak iskolapadszerü képzésben ismerjék meg, hanem a közvetlen tanulás érvényesüljön. Ezeket a készségeket legjobban másoktól tudják megtanulni a klasztervezetők és mivel közös uniós költségvetésből kerül finanszírozásra, így minden uniós ország klaszterei részt tudnak venni. A pénzügyi támogatások mellett, tehát az utóbbi időben egyre fontosabbá válnak a soft jellegü támogatások.

Az elmúlt évek klaszterizációs folyamatainak eredményeit tekintve, voltak olyan hiányosságok, amelyeket utólag ismertek fel, mint például, hogy a régiók közötti koordináció hiánya miatt párhuzamosan jöttek létre klaszterek. Viszont összességében a nagyszámú támogatott induló klaszterből 5-8 top magyar klaszter és további 20 szintén jól müködö együttmüködés jött létre. A jók azért müködhetnek most, mert 2007-től elindult ez a támogatási rendszer. Végig kellett menni ezen a folyamaton. Ugyan az induló klaszterek nagy rész eltünt, de a most jól müködő klaszterek is akkor jöttek létre. A Pénzügyminisztérium részéről elegendőnek értékeli a most müködő sikeres klaszterek számát, mivel elég, ha húzó iparáganként van egy-két nagyon erős klaszter, amely akár 70-80 tagot magába tömörít az adott iparágból és persze néhány kisebb, mint egyfajta utánpótlás. Az informatikai klaszterek területén már volt egy két összeolvadás, bár ez most a kötelezettségek miatt nem túl egyszerü, de az informatikai klaszterek között elindult egy jövőbemutató fórumszerü kooperációs és rendszeres kommunikációs tevékenység.

\subsection{Esettanulmány eredményei, legfontosabb megállapítások}

Összefoglalóan megállapítható, hogy a Szoftveripari Innovációs Pólus Klaszter megfelelő alapokkal rendelkezik, a működési múlt, a tagság és az iparág tekintetében. Más klaszterekkel intenzív együttmüködéseket folytat és tervez a jövőben, a szolgáltatások fejlesztésére is nagy energiákat fordít, továbbá az évek során kiépített nemzetközi kapcsolatait próbálja meg minél inkább erősíteni. A közel 10 éves fennállása során számos nehézséggel kellett megküzdeni, 
rendszeres átalakuláson és megújuláson ment és megy jelenleg is keresztül, de összességében a négy területet vizsgálva eredményesnek mondható és jó eséllyel még akár 10 év múlva is stabilan müködő klaszter lehet. A sikerességet korlátozó tényezőként talán a klaszter nagysága és a méretgazdaságossági szempontok merülnek fel, de ezt a problémát a szolgáltatások és az együttmüködési ökoszisztéma szélesebb körre vonatkozó kiterjesztésével próbálja meg áthidalni a vezetés. Az esettanulmányból kidolgozásával az alábbi 27 . ábrán megfogalmazott tanulságok vonhatóak le:

\section{7. ábra Az esettanulmány legfőbb megállapításai}

\section{Méret}

-Méretgazdaságosság. Nagyobb 70-80 taggal rendelkező klaszterek ösztönzése, mely létrejöhet összeolvadásokkal vagy megoldás lehet a klasztermenedzsment szolgáltatásait kiterjeszteni egy szélesebb körre

\section{Együttmüködések}

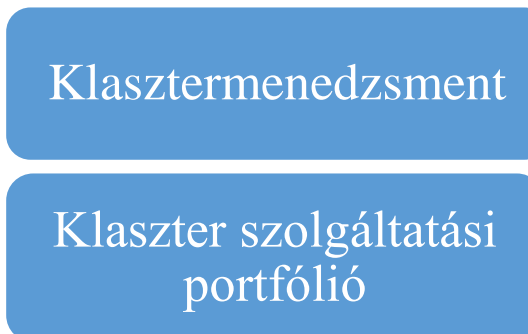

Stratégiai célok

\section{$\mathrm{K}+\mathrm{F}+\mathrm{I}$}

• Egyre komplexebb együttmúködések a klaszteren belül, akár ágazatközi szinten. Együttmüködések más klaszterekkel.
-A klasztermenedzsereknek folyamatosan fejleszteniük a kompetenciáikat és nagyon jól kell ismerniük a klaszter szakterületét.
-Piacképes menedzsment szolgáltatások kialakítása, a hagyományos menedzsment szemléleten túl. A tagok igényeinek alaposabb megismerésén van a hangsúly.

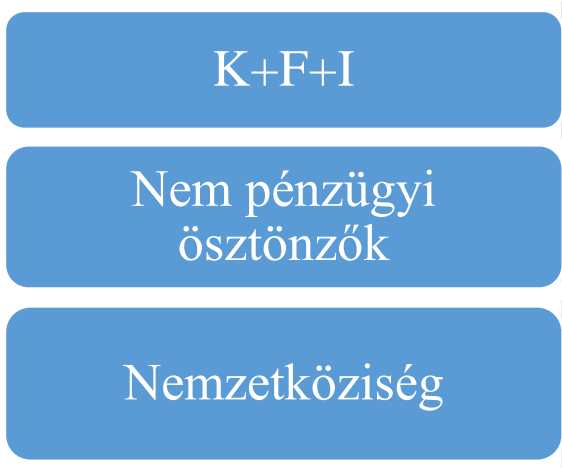

-Meg kell ismerni a szakterület legújabb trendjeit és a beépíteni a klaszter tevékenységei közé.

- Piacképes termékek és szolgáltatások kifejlesztése a cél, melyből a klasztertagok és akár a menedzsment is profitál.

-Egyre nagyobb jelentősége van a klasztermenedzsment képzéseknek, coachingnak, tapasztalatcserének.

-Nemzetközi láthatóság, nemzetközi kapcsolatok építése az egyik legfontosabb terület a klasztermenedzsment és klasztertagok szempontjából 


\section{ÉRTÉKELÉS}

Az értekezés célja az volt, hogy bemutassa az elmúlt, több, mint 10 év célzott klaszterfejlesztési programjainak eredményességét a Dél-alföldi Régió példáján keresztül, megvizsgálja a régióban létrejött klaszterek sikerességét és kiemelje azon területeket, amelyek még további fejlesztésre vagy átalakításra szorulnak. A szakirodalom és a nemzetközi gyakorlatok részletes vizsgálata alapján elvégzett kutatás, több érdekes témakörre világított rá a régióban végbement klaszteresedési folyamatok kapcsán.

A régió klasztereinek nagy része 2007 után, a széles körben rendelkezésre álló pályázati támogatásoknak köszönhetően alakult ki, azonban csak nagyon kis százalékuk jutott el a fejlett érettségi szakaszba és müködik jelenleg is. A létrejött klaszterek szakterületüket tekintve jól illeszkednek a régió stratégiai fejlesztési irányaihoz és lefedik a régió kiemelt iparágait, kutatási területeit úgy, mint például az S3 stratégiában is megfogalmazott egészségipar, jármü- és gépipar, építőipar, energetika, csomagolástechnika, szoftverfejlesztés és lézertechnológiák. A régió klaszterei föként a kis-és középvállalkozások stratégiai szintü, iparági értékláncok mentén szerveződő összefogására épülnek, de a kkv-k mellett részt vesznek bennük a legfontosabb nagy- és multinacionális vállalatok, továbbá döntő többségükben helyet kaptak a legfontosabb kutatási szereplök, egyetemek, kutatóintézetek is. Méretüket tekintve a méretgazdaságossági szempontoknak még nem felelnek meg maradéktalanul, de egyre több klaszter igyekszik különböző módszerekkel, klaszterfúziókkal, tagbővítéssel, vagy szélesebb körü klaszteres együttmüködési ökoszisztéma kiépítésével elérni a hatékony müködéshez szükséges kritikus tömeget. A szereplők közötti együttmüködéseket és a kölcsönös bizalmi viszonyokat jól átgondolt stratégiák mentén szerveződő közös projektekkel, beruházásokkal, kutatás-fejlesztési tevékenységekkel alapozták meg. A közös célok átfogó koordinálására kijelölt profi klasztermenedzsment szervezetek aktív tevékenységgel és célzott szolgáltatásokkal igyekeznek támogatni a klaszter sikerét és elfogadottságát hazai és nemzetközi szinten egyaránt A fentiek alapján a disszertáció első hipotézisét, miszerint az elmúlt évek intenzív klaszterfejlesztési támogatásainak köszönhetően a Dél-alföldi Régió klasztereinek sikerült kialakítaniuk a sikeres müködéshez szükséges alapfeltételeket, sikerült alátámasztani.

A dolgozat második hipotézisét, miszerint a Dél-alföldi Régió klaszterei kihasználják a klaszteres együttműködésből származó előnyöket, jelentős hozzáadott értéket képviselnek a klasztertagjaik számára, mely előnyöket erősítésében a klasztermenedzsment szervezeteknek nagy szerepe van, csak részben sikerült igazolni. A klaszterek az interjúalanyok megítélése alapján ugyan kiemelt hozzáadott értéket képviselnek a tagjaik számára a pályázati források megszerzése és a közös kutatás-fejlesztési projektek ösztönzése terén, azonban a pályázati források könnyebb elérése, mint elöny véleményem szerint a pályázati források csökkenésével és esetleges megszünésével nem tartható fent túl sokáig. A kutatás-fejlesztési projektek generálására vonatkozó hozzáadott érték pedig a klaszterek közös $\mathrm{K}+\mathrm{F}$ tevékenységeinek vizsgálata alapján, még inkább csak potenciális előnyként, mintsem gyakorlati tapasztalatként jelenik meg. A klaszter menedzsment szervezetek egyre bővülő és fejlődő szolgáltatásokkal igyekeznek az együttmüködésből származó előnyöket maximalizálni, azonban a menedzsment szervezetek müködésének és a klasztertagok elégedettségének fenntartása érdekében, sokkal inkább a konkrét igényekre épülő, piaci alapon szerveződő szolgáltatási portfólióra szükséges koncentrálniuk, mintsem az általános együttműködést támogató tevékenységekre.

A disszertáció harmadik hipotézise, mely szerint a Dél-alföldi Régió klaszterei a regionális tudáscentrumok köré épültek, magukban foglalják a kutatás-fejlesztési tevékenységek 
legfontosabb szereplőit, ezért kiemelkedő kutatás-fejlesztési és innovációs tevékenységet folytatnak, csak részben igazolódott.

A régió klaszterei valóban a legfontosabb regionális tudásközpontok és kutatási területek köré szerveződtek, valamint az egyetemek, kutatóintézetek szerepe figyelemre méltó, hiszen szinte alig van olyan klaszter, amelyben ne vennének részt. A klaszterek innovációs tevékenységeket tekintve a klaszterek nagy része bonyolított már le közös $\mathrm{K}+\mathrm{F}+\mathrm{I}$ projektet, mégis ezek eredményei még kevéssé realizálódtak új piaci termék vagy szolgáltatás formájában. Az egyetemeket nem tekintik meghatározó szereplőnek a klaszteren belül és a velük való együttmüködés legnagyobb problémájaként az eltérő müködésből és motivációból adódó nehézségek jelentek meg. A klasztermenedzserek különböző innováció menedzsment szolgáltatásokkal és rendezvényekkel igyekeznek támogatni a klaszteren belül megvalósuló hatékony tudástranszfer tevékenységeket. A klaszterek tisztában vannak az innovációt ösztönző tényezők fontosságával, azonban azok fejlesztésére még saját megítélésük alapján is további lépéseket kell tenniük.

A negyedik hipotézist, mely szerint az elmúlt évek fejlesztései és tapasztalatai révén a Délalföldi Régióban létrejött klasztereknek sikerült stabil pénzügyi és szakmai növekedési pályára lépniük, így a jövőben önfenntartóvá válhatnak, lényegében nem sikerült alátámasztani. A régió klasztereinek finanszírozási szerkezetében még meghatározó a pályázati források jelenléte és nem tudták magukat függetleníteni a külső forrásoktól. Néhány klaszter már felismerte, hogy a menedzsment szervezet fenntartásához és az együttműködésekből származó előnyök fokozásához piaci alapra kell helyezni a szolgáltatásaikat és müködésüket, azonban az ez irányú lépéseket még csak most kezdték el megvalósítani. A szakmai fenntarthatóságot ösztönözni képes nemzetközi és ágazatközi együttmüködések ugyan már szerepelnek a jövőre vonatkozó konkrét céljaik és fejlesztési elképzeléseik között, azok gyakorlati megvalósítására vonatkozóan azonban még csak elvétve láthatunk példát.

$\mathrm{Az}$ interjús elemzés és az esettanulmány eredményeinek vizsgálata alapján szépen kirajzolódik az a néhány terület, ahol még külső és belső fejlesztésre szorulnak a régió klaszterei a hosszú távú eredményesség érdekében. Az eredmények gyakorlati hasznosíthatósága és ezek alapján tett javaslataim a következő pontokban foglalhatóak össze:

\section{A klasztermenedzserek számára javasolt belső fejlesztési irányok:}

- A pályázati támogatások megszerzése helyett sokkal inkább az üzleti haszonnal kecsegtető közös projektekre és fejlesztésekre szükséges koncentrálni.

- A klasztermenedzsmentnek a hagyományos menedzsment szemléleten túl olyan szaktudással is rendelkeznie kell, amely segítségével jobban megérti a szakterület legfontosabb problémáit és a klasztertagok speciális igényeit.

- A klasztertagok számára nyújtott szolgáltatásokat is tovább szükséges fejleszteni, annak érdekében, hogy azok minél inkább a szakmai igényekre reagáljanak, amit akár egy szélesebb vállalkozói kör számára is képesek lehetnek biztosítani.

- A különböző kapcsolódó ágazatokkal vagy más klaszterekkel való együttmüködések ösztönzésére is kiemelt figyelmet javasolt fordítaniuk a klasztereknek.

- Az egyetemi-vállalati együttmüködésekre sokkal inkább szükséges koncentrálni, mivel ez egy részben kihasználatlan terület. Ehhez nagyon aktív kezdeményező szerep és nagyfokú nyitottság szükséges a klasztervezetők és az egyetemi szereplök részéről egyaránt. 
- A klaszter méretének bővítése, vagy a klaszterek közötti együttmüködések szorosabbá tétele is fontos szempont a méretgazdaságossági küszöb elérése és a klaszterek nemzetközi szintü vonzerejének növelése érdekében.

- A klaszterek pénzügyi fenntarthatóságára vonatkozóan konkrét üzleti modell kidolgozása szükséges. A klaszter tevékenységeit, szolgáltatásait üzleti alapokra javasolt helyezni.

- A nemzetközi piacok megismerése, a klaszter nemzetközi láthatóságának növelése és a nemzetközi kapcsolatok elősegítése még számos erőfeszítést igényel a menedzsment részéről. Ehhez igénybe kell tudni venniük a klaszterek fejlődését és a külkapcsolatok kialakítását célzó nemzetközi szervezetek támogatásait.

- A forrásszerzési tevékenységeiket át kell helyezniük nemzetközi szintre.

- A nemzetközi tevékenységekhez szükséges kompetenciák és tudás fejlesztésére (pl. idegen nyelvek ismerete, külpiacok megismerése, közvetlen uniós források elérése) erőforrásokat kell allokálniuk a klasztereknek.

\section{A klaszterpolitikai döntéshozók számára az alábbi javaslatok fogalmazhatóak meg a klaszterek támogatásával kapcsolatban:}

- A klaszterek támogatására a közvetlen pénzügyi források helyett inkább a közvetett, nem pénzügyi jellegü ösztönzők alkalmazása javasolt, hiszen ezek kevésbé vonzzák a forrásvadász együttmüködéseket, mégis erősíthetik a klasztermenedzsment motivációját és tevékenyégének hatékonyságát.

- A nem pénzügyi ösztönzők közül a sikeres nemzetközi gyakorlatok megismertetése kiemelten fontos, akár üzleti modell szintjéig is.

- Klasztermenedzserek tudásának, kompetenciáinak bővítésére irányuló kezdeményezések, köztük a gyakorlatorientált képzések, kurzusok indítása javasolt.

- A klasztermenedzserek munkájának szakmai (ágazatspecifikus) segítése, mentorálása fontos terület.

- Nemzetközi együttmüködések és piacra lépések támogatása (nemzetközi szakmai konferenciákon, üzletember találkozókon való részvétel biztosítása) javasolt.

- Célzott pénzügyi forrásokra kizárólag a kutatás-fejlesztési és innovációs együttműködések fokozásához lehet szükség. Olyan piacorientált közös kutatásfejlesztések támogatására javasolt koncentrálni, melynek a piacon értékesíthető közös termék vagy szolgáltatás az eredménye.

- Az egyetemek és kutatóintézetek aktivizálására, hatékony bevonására irányuló célzott programok, például klaszteres innovációs voucher program bevezetése javasolt. 


\section{ÖSSZEGZÉS}

A dolgozatom fó célja a Magyarországon lezajlott klaszteresedési folyamatok sikerességének és problematikájának vizsgálata volt, melyhez a Dél-alföldi Régiót választottam ki, elemzési mintaterületként.

A Dél-alföldi Régióban az elmúlt évek támogatásainak köszönhetően kellően nagy számban és változatos területeken jöttek létre azon klaszterek, amelyek magukban tömörítik a régió adott iparágainak legfontosabb gazdasági és kutatási szereplöit. A klaszterekkel kapcsolatos kvalitatív kutatásom során tehát azt próbáltam vizsgálni, hogy a Dél-alföldi Régióban létrejött klaszterek mennyiben tekinthetőek sikeresnek és milyen problémák, akadályozó tényezők merültek fel a klaszterek müködése során. A részletes szakirodalmi kutatás alapján kirajzolódtak azok a fö területek, amelyek alapján a klaszterek sikeressége mérhetö, elemezhető. A többféle szempont és módszer közül inkább azokra a tényezőkre voltam kíváncsi, amelyek kvantitatív eszközökkel kevésbé vizsgálhatóak.

A kutatásomban többféle kutatási módszert alkalmaztam annak érdekében, hogy átfogó képet kapjak a Dél-alföldi Régióban lezajlott klaszteresedési folyamatokról, a létrejött klaszterek jellemzőiröl, sikerességéről és azokról a problémákról, nehézségekről, amelyek a fejlődésüket nehezítették. A kutatási módszertan legfontosabb részét a Dél-alföldi Régió klasztereinek körében végzett interjús elemzés adta. Félig strukturált interjúkat készítettem az elözetesen kiválasztott klaszterek vezetőivel és menedzsereivel, annak érdekében, hogy mélyebb és részletesebb információhoz jussak a klaszterek sikerességével kapcsolatos tényezőkre vonatkozóan, továbbá, hogy megismerjem a klasztervezetők ezekkel kapcsolatos tapasztalatait és egyéni nézőpontjait. Ezt egészítettem ki a klaszterekről elérhető gazdasági adatok statisztikai elemzésével, továbbá egy konkrét klaszter fejlődését és sikerességét részletező esettanulmánnyal.

Ezek alapján a dolgozatomban a klaszterek sikerességét négy szempont szerint közelítettem meg:

Elsőként a sikeres működéshez szükséges alapfeltételek rendelkezésre állását elemeztem a vizsgált klasztereknél, tehát, hogy olyan stabil háttérrel rendelkező klaszterek jöttek-e létre a régióban, amelyekre a későbbi fejlesztési folyamatokat építeni lehet. A szakirodalmi áttekintés alapján ugyanis beigazolódott, hogy a sikeres müködés mögött azonosított kulcstényezők között is van néhány olyan alapvető fontosságú, amelyek megléte szinte minden klaszter esetében szükséges. Ilyen alapfeltételek a földrajzi koncentráció és specializáció, a megfelelö klaszterméret és összetétel, a tagok közötti együttmüködési dinamika és kölcsönös bizalom, a közös szakmai háttér és célok, valamint a professzionális menedzsment szervezet.

Az alapfeltételek megléte után a klaszterek által nyújtott előnyöket és hozzáadott értéket vizsgáltam, hiszen a klasztereknek olyan értéket és szolgáltatásokat kell közvetíteniük a tagjaik számára, amelyek hosszú távon biztosítják a szereplők elégedettségét és a klaszteres együttmüködési forma müködöképességét. Mivel a klaszterek által nyújtott elönyöket a klasztermenedzsment szervezetek számos tevékenyéggel és célzott szolgáltatásokkal igyekeznek erősíteni, a klaszterek hozzáadott értékének vizsgálatakor a klasztermenedzsment szervetek szolgáltatásait is részletes elemzés alá vettem.

A klaszteren belüli innovációs tevékenységek minősége, meghatározhatja a klaszter egészének sikerességét, továbbá a klaszterek egy adott térség innovációs teljesítményének szempontjából is kiemelkedő szerepet tölthetnek be, ezért a létrejött klaszterek $\mathrm{K}+\mathrm{F}+\mathrm{I}$ kapcsolatait és tevékenységét is bevontam a kutatásomba. Megvizsgáltam továbbá, hogy a különböző innovációt ösztönző tényezők mennyiben érvényesülnek a régió klasztereinél. 
A klaszterek sikeressége szempontjából negyedik tényezőként a klaszterek hosszú távú pénzügyi és szakmai fenntarthatóságát vizsgáltam, hiszen hiába alakultak ki a megfelelö együttmüködési formák, ha azokat hosszú távon nem sikerül fenntartani. A hosszú távú stabil müködéshez azonban pénzügyi önállóságra, folyamatos szakmai megújulásra van szükség a klaszterek részéről.

A hipotéziseimet is a fenti négy szempont mentén állítottam fel és leginkább arra voltam kíváncsi, hogy mely területeken teljesítettek jól a régió klaszterei és melyek azok a kritikus pontok, ahol nehézségekbe ütköztek, vagy további fejlesztésekre szorulnak. A kutatási eredmények alapján igyekeztem pontosan meghatározni azokat a területeket, amelyeken további külső vagy belső beavatkozásra van szükségük a dolgozatomban definiált sikeresség eléréséhez.

Végezetül a hipotézisek vizsgálata és az empirikus kutatásom révén az alábbi következtetésekre jutottam a Dél-alföldi Régió klasztereinek sikerességét illetően:

Tézis 1: A Dél-alföldi Régió klaszterei rendelkeznek a sikeres müködéshez szükséges alapfeltételekkel.

Tézis 2: A Dél-alföldi Régió klaszterei jelenleg még leginkább csak a kutatás-fejlesztési tevékenységek és a pályázati források megszerzése tekintetében nyújtanak kiemelkedő hozzáadott értéket a tagjaik számára, a menedzsment szervezetek szolgáltatásainak pedig inkább az egyes hosszú távú kitörési pontokra (pl. nemzetközi piacok elérésére, nemzetközi kapcsolatok erősítésére) lenne érdemes koncentrálni.

Tézis 3: A Dél-alföldi Régió klaszterei valóban jelentős tudásbázisra és a legjelentősebb tudáscentrumok köré épültek, azok kutatás-fejlesztési és innovációs tevékenysége azonban még elmarad a várakozásoktól és számos ponton fejlesztésre szorul.

Tézis 4: A Dél-alföldi Régió klaszterei még erősen függnek a külső támogatásoktól, pályázati forrásoktól és kevésbé tudták megteremteni a pénzügyi fenntarthatósághoz szükséges bevételi forrásokat. A szakmai fenntarthatóságot tekintve, pedig a nemzetközi és ágazatközi együttmüködések kialakítása és erösítése szükséges.

A fenti eredmények alapján összességében megállapítható, hogy a Dél-alföldi Régió klaszterei ugyan kialakították a sikeres müködéshez szükséges alapokat, a klaszterelőnyök, az innováció és a pénzügyi és szakmai fenntarthatóság terén azonban még számos ponton külső és belső fejlesztések szükségesek.

Mivel kutatásom kifejezetten a Dél-alföldi Régió klasztereit vizsgáltam, ennek megfelelően az eredmények is nyilvánvalóan erre a területre vonatkoznak, azonban mivel a hazai klaszterek az egységes fejlesztési háttérnek köszönhetően sok hasonlóságokat mutatnak a kialakulás, müködési háttér, finanszírozás terén így az eredmények részben alkalmazhatóak a hazai klaszterekre vonatkozóan is.

A dolgozat eredményei többféleképpen is hasznosulhatnak a gyakorlatban. A kutatásom eredményei részletesebb információkkal szolgálhatnak a gazdaságfejlesztési programok döntéshozói számára, ezáltal hozzájárulhatnak a további klaszterfejlesztési programok és intézkedések legfőbb irányainak kidolgozásához, hiszen rávilágítanak a klaszteres együttműködések gyengeségeire, hiányosságaira és azonosítják azokat a területeket, amelyek támogatásával jelentős hatás érhető el a jövőben. A kutatás eredményei másrészről a klaszterek vezetői és résztvevői számára is hasznosak lehetnek, hiszen összehasonlítási alapot és keretrendszert nyújthatnak a saját eredményességük kiértékeléséhez és a fejlesztési fókuszterületeik kijelöléséhez. Harmadrészt a kutatás bizonyos eredményei a vállalkozások és a lakosság szélesebb körében is alkalmazhatóak, tájékoztatási és szemléletformálási jelleggel, 
a klaszterekkel kapcsolatban kialakult negatív megítélés enyhítésére. Az eredmények ugyanis rávilágítanak, hogy csak a klaszterek egy része volt kizárólag forrásvadász kezdeményezés és azok hatékony müködtetéséhez és hosszú távú fenntartásához céltudatos, kitartó munkára van szükség a klasztermenedzserek részéről, továbbá, hogy a magyarországi klasztereknek van egy olyan szűk rétege, amely valós együttmüködéseken nyugszik és jelentős piaci eredményeket tud felmutatni.

A dolgozat eredményei számos további kérdést is felvetnek, melyek alapján a kutatás továbbvitele többféle irányban és módszerrel is elképzelhető. Az eredményeket javasolt lenne tovább finomítani és pontosítani a klaszterben résztvevők véleményének, tapasztalatának és motivációjának beépítésével, melyet elsősorban a klasztertagok körében lefolytatott kérdőíves vizsgálattal lehetne alátámasztani, azonban a klasztertag vállalatok válaszadási hajlandósága igen alacsony. A kutatás időbeni összehasonlítása érdekében történő későbbi megismétlése is érdekes eredményekkel szolgálhat, hiszen fény derülhet arra, hogy a részben sikeresnek ítélt klaszterek mennyiben állják meg a helyüket hosszabb távon és milyen irányokban fejlődnek tovább. A kutatást nemzetközi vonatkozásban is javasolt lenne lefolytatni, a magyarországi helyzethez hasonló körülményekkel és háttérrel rendelkező országok (pl. V4 országok) klasztereinek körében, ugyanis érdekes lenne azt megvizsgálni, hogy más országok milyen nehézségekkel szembesültek a klaszteresedés kapcsán és milyen megoldási javaslatok alakultak ki azok fenntartása kapcsán. Utoljára, de nem utolsó sorban talán a legérdekesebb kutatási irány a klaszterben müködő szervezetek gazdasági, foglalkoztatási és kutatás-fejlesztési adatainak időbeni változásának részletes elemzése révén számszerüsíthető adatokkal és mutatókkal alátámasztani azok hatékonyságát és eredményességét. 


\section{EVALUATION AND SUMMARY}

The objective of the dissertation was to investigate the effects of the cluster development programs from the past 10 years and to examine the success of the clusters in the Southern Great Plain region in detail, highlighting those fields, which need further development or reorganization. Based on detailed investigation on literature and international practices the research highlighted many interesting issues regarding clustering development taking place this region.

Thanks to the expansively available financial resource most clusters in this region was established after 2007, although very little percentage reached the stage of development and operate nowadays. Regarding the professional field of the existing clusters, they fit well in the directions for regional strategic development and cover the top business sectors, research areas of the region for example machinery, automotive industry, healthcare industry, building industry, energetics, software development and laser technology. Regional clusters are mainly built on the collaboration of small and medium sized enterprises organized along industrial value chains at strategic level, but beside them the most important large and multinational companies, universities and research centres also receive an important place. Concerning their size, they do not fully correspond with the aspects of economies of scale, although more and more clusters aim to reach the critical mass for efficient operation by different methods like cluster fusion, member extension or by developing a broader cluster cooperation ecosystem. The collaborations between members and the mutual relationships of trust are based on wellconceived strategies, organized along shared projects, investments, research and development activity. The comprehensive coordination of common goals is conducted by assigned cluster management organizations, whose aim is to support the success, the domestic and international acceptance of clusters by active work and targeted services. On the basis of the above, the first hypothesis of the dissertation, namely that, thanks to the intense financial support of cluster development in the last years, the clusters of the Southern Great Plain region succeeded in developing the background and basic conditions for successful operation, could be confirmed.

The second hypothesis according to which the clusters of the Southern Great Plain effectively use benefits gained from cooperation between clusters, and represents a significant added value to the cluster members, could be partially proved. According to the interviewees, clusters represent a significant added value in gaining funding to its members and incentivizing the common research and development programs, though in my opinion, the better availability of funding as an advantage cannot be sustained much longer because of the decrease and probable termination of them. Based on the examination of their common $R \& D$ activity the added value of the generation of common research and development programs appear only as a potential advantage even more than based practical experience. Cluster management organizations strive to maximize the cooperation derived advantages with expanding and developing services, although for sustainability of the organizations' operation and cluster members' satisfaction they rather need to concentrate on the concrete needs and demands and a market based service portfolio rather than the support of general activity.

According to the third hypothesis of the dissertation that could be confirmed partially, the clusters of Southern Great Plain are built around significant knowledge bases and centres, including the most important research and development actors, that is why they conduct a significant $R \& D$ and innovation activity. Actually, regional clusters are organized around the most important regional knowledge centres and they cover the most significant research areas of the region. The role of universities, research centres are remarkable because there are a few clusters in which they do not participate in. Concerning the innovation activities of clusters, 
most of them have conducted R\&D\&I projects, although their results slightly show in clusters. Universities are not considered to be significant within clusters and the biggest problem with the joint work is derived from the differences in operation and motivation. Cluster managers seek to support the efficient knowledge transfer activities within clusters with different innovation management activities and events. Clusters are aware of the importance of innovation incentives, however - according to them - they need to take further steps for their own development.

The forth hypothesis could not be substantiated, namely that, as a result of the developments and experiences in the last few years, clusters of the Southern Great Plain succeeded to take the path to a stable financial and professional growth and, thus they might become self-sustaining in the future.

In the financial frame of regional clusters, the presence of tenders is determining and yet, they could not make themselves independent from external financial resources. Some clusters acknowledged that their services and operation should be more market-based to sustain the management organization and to elevate the cooperation-gained advantages, although some unidirectional steps just started to be implemented. Though, international and inter-sectoral cooperations are among their future goals and development ideas for the encouragement of professional sustainability, however in the matter of their implementations can be rarely seen as an example.

Based on the in-depth interviews and examinations of case study results, those fields outline clearly, where regional clusters need internal and external development for long-distance efficiency. The practicality of results and my proposals on this basis can be summarized in the following points:

\section{For cluster managers, the proposed internal development directions:}

- Instead of gaining financial resource of tenders they should concentrate on those common projects and developments which provide business benefits.

- Beyond traditional management approach, cluster managers will need professional knowledge to understand the most important problems of the professional field and the special needs of the members.

- Provided services need to be further developed to respond professional demands as much as possible, which could assure a wider range of entrepreneurial sphere.

- Special attention needs to be paid to incite cooperations with other relevant sectors or clusters.

- It is necessary to concentrate on university-company cooperations as much as possible because it is a partly unexploited possibility. For this, equally active initiative role and a high level of openness is needed from cluster leaders and university actors.

- Size expansion or strengthening inter-cluster cooperations is a very important factor for reaching the economies of scale threshold and for increasing international attractiveness of clusters.

- A concrete business model needs to be elaborated for financial sustainability of clusters. Cluster activities and services should be commercialized.

- From management it requires effort to understand international markets, to increase international visibility of clusters and to promote international relationships. For this, they need to resort to the development of clusters and the support of external relations aiming international organizations.

- The clusters finance raising activities should be transferred to international level. 
- Clusters need to allocate resources to the development of competence and knowledge for international activities (i.e.: foreign language knowledge, external market knowledge, capture of direct European Union resources).

\section{Regarding cluster support the following proposals can be conceived for cluster decision- making bodies and authorities:}

- Instead of the use of direct financial resources, indirect, not-financial type of incentives should be applied for cluster support because these draw less resourcehunting cooperations but could contribute to the strengthening of the cluster management's motivation and activity efficiency.

- Among non-financial type of incentives, familiarization of international practices has major importance, even to the level of business model.

- There might be a need for initiatives for broadening the cluster managers' competence and knowledge like practice-oriented training and courses.

- It is proposed to support international cooperation and market access (international professional conferences, participation in stakeholders' meetings).

- The sector specific professional support or mentoring of the cluster managers' work is an important area.

- The need for direct financial resources is only required in the enhancement of cooperations of research, development and innovation. It is suggested to support market-oriented common research and development activities which result marketable products or services.

- It is recommended to activate universities and research centres with the introduction of targeted programs for example cluster innovation voucher programs.

Finally, through the examination of the hypotheses and as a result of my empirical research, I came to the following conclusions regarding the success of the clusters of the Southern Great Plain Region:

Thesis 1: The clusters of the Southern Great Plain Region have the necessary prerequisites for successful operation.

Thesis 2: At present, clusters in the Southern Great Plain Region provide the greatest added value to their members only in terms of research and development activities and access to grant resources, the services of the management organizations should be focused on the different long-term breakthrough points (eg. access of international markets, strengthening of international relations).

Thesis 3: The clusters of the Southern Great Plain Region are built on a significant knowledge base and around the most important knowledge centres, but their R\&D and innovation activities are still below expectations and in many points they need to be improved.

Thesis 4: The clusters of the Southern Great Plain Region are still heavily dependent on external support, funding sources and they have not really been able to generate the sources of income needed for financial sustainability. However, in terms of professional sustainability, international and intersectoral cooperation needs to be developed and strengthened. 
On the basis of the results above, it can be concluded that the clusters of the Southern Great Plain Region have established the necessary bases for successful operation, but there are still many external and internal developments deeded in the areas of cluster advantages, innovation and financial and professional sustainability.

\section{Applicability of the research results}

The results of this dissertation can be of different use in practice. The achievements of the cluster survey can provide detailed information for decision-making bodies of economic development programs, thus they contribute to the further development of cluster programs and major direction of actions, since they reveal the weakness and deficiency of cluster cooperations and identify those fields by whose support significant effects can be achieved. On the other hand, the results can be of use for cluster leaders and members too, since they can provide the basis of comparison and framework to evaluate their own efficiency and to appoint their development focus areas. Thirdly, certain results of this dissertation can be applied to a wider circle of entrepreneurs and resident population on informational and awareness-raising basis to reduce the negative judgement of clusters. Namely, the results reveal that only in one part of clusters had resource hunting initiative, and for efficient operation and long-distance maintenance goal-oriented, persistent work is needed from cluster managers, and further, there is a tight layer of Hungarian clusters which are based on real cooperation and are able to show significant market outcomes.

\section{Further directions of the research}

The outcomes of this dissertation raise numerous further questions on the basis of which the research is possible to be continued with a wide variety of directions and different methods. The results are recommended to be further refined and specified with the inclusion of cluster members' opinions, experiments and motivations, which can be supported by questionnaire survey conducted among them, although their willingness to answer is very low. For time comparison, the later repeat of research might serve interesting results, since it might come to light that clusters deemed partly successful will have pulled through long term and in which direction they will have developed. The research would worth to continue in international comparison with other clusters in countries which has similar situation and background to Hungary (i.e.: V4 countries), since it would be interesting to examine, that with what difficulties other countries face regarding clustering and what kind of proposing solutions have evolved in sustaining them. Last but not least, maybe the most interesting research direction is the detailed time-variant data analysis of economic, employment and researchdevelopment of in-cluster organizations which results quantified data and indicators to support clusters' efficiency and effectiveness. 


\section{IRODALOMJEGYZÉK}

ÁBrAhÁM, Zs. - SimONovits, G. - Szigel, F. 2010: Bárhol megoldás lehet egy klaszter? Klaszterek és nemzeti kultúra - TDK dolgozat, BCE, HR és szervezetfejlesztés szekció.

Amighini, A. - RabellotTI, R. 2006: The Effects of Globalization on Italian Industrial Districts: Evidence from the Footwear Sector, European Planning Studies, 14 (4): 485502.

Andersson, T. - SchwaAg-Serger, S. - SörVik, J. - Wise, E. 2004: The Cluster Policies Whitebook, International Organisation for Knowledge Economy and Enterprise Development, Stockholm

AsHEIM, B.T. 2000: Industrial districts: the contribution of Marshall and beyond. In Clark, G.L. - Feldman, M.P. - Gertler, M.S. (eds): The Oxford handbook of economic geography, Oxford University Press, Oxford, 413-431.

BeCATtini, G. 1989: Il distretto industriale marshalliano come concetto socio-economico, Stato e Mercato, 25: 111-128.

Becattini, G. 1990: 'The Marshallian industrial district as a socio- economic notion', in F. Pyke, G. Becattini, W. Sengenberger (eds), Industrial Districts and Inter- Firm Cooperation in Italy, Genova, International Institute for Labour Studies, 37-51.

BogGs, J. S. - RANTISI, N. M. 2003: The 'regional turn' in economic geography. Journal of Economic Geography, 3.: 109-116.

Boschma, R. 2005: Proximity and Innovation: A Critical Assesment. Regional Studies, 39 (1): 61-74.

Boschma, R.- TeR WaL, A. L. J. 2007: Knowledge networks and innovative performance in an industrial district: the case of a footwear district in the South of Italy. Industry and Innovation, 14 (2):177-199.

BRESCHI, S. - MALERBA, F. 2005: Sectoral innovation systems: technological regimes, schumpeterian dynamics, and spatial boundaries. In Edquist, C. (ed): Systems of innovation. Technologies, institutions and organizations. Routledge, London - New York, 131-156.

Broekel, T., - Boschma, R. 2016: The cognitive and geographical structure of knowledge links and how they influence firms'innovation performance, Regional Statistics, 6 (2): 3-26.

BRusCO, S. 1992: The idea of the Industrial District: Its Genesis, in Pyke F., Becattini G., Sengenberger W. (eds.), Industrial Districts and Inter-firm Cooperation in Italy, International Institute for Labour Studies, Geneva, 10-19.

Buhl, C. M. - KöcKeR, G. M. 2009: Cluster Management Excellence. Volume1: Network services http://www. kompetenznetze.de/service/bestellservice/medien/ en_clustermanagementi_online.pdf1; (Letöltve: 2011.11.10.)

BuZÁS N. - PRÓNAY Sz. 2013: A potenciál elemzés és a partnerség szerepe a korai fázisú kutatási eredmények hasznosításában In: Inzelt A. - Bajmócy Z.: Innovációs rendszerek -szereplők, kapcsolatok és intézmények, JATE Press, Szeged, 21-39.

BUZÁs, N. 2000: Klaszterek: kialakulásuk, szerveződésük es lehetséges megjelenésük a DélAlföldön, Tér és Társadalom, 14 (4): 109-123.

BUZÁs, N. 2005: The need for capacity building at universities in CEE countries for successful technology transfer, Science and Innovation, 1. (2005): 42-49

CASTELlS, M. 1996: The rise of the network societym Blackwell, Oxford

Christensen, T. A.-LÄMMER-GAMP, T.-MEIER ZU KÖCKER, G. 2012: Let's make a perfect cluster policy and cluster programme Smart recommendation for policy makers, VDI/VDE Innovation Technik GmbH, Berlin/Copenhagen, https://www.clusteranalysis.org/downloads/Clusters_web_singlepage_06092012.pdf

(Letöltve: 2014.09.16.) 
COLOSSEUM BUDAPEST KFT. 2015: A hazai klaszterakkreditációs rendszer felülvizsgálata és a megújítására vonatkozó javaslatok elkészítése, a hazai helyzetkép és a nemzetközi példák alapján, valamint javaslattétel a 2014-2020-as időszakra vonatkozó klaszterfejlesztési koncepció tartalmára http://www.klaszterfejlesztes.hu/content/ cont_5007fe14d8ba95.44814012/klasztertanulmany_2015.pdf (Letöltve: 2018.06.18.)

CoOKE, P. 2001: Clusters as Key Determinants of Economic Growth: The Example of Biotechnology. Cluster Policies - Cluster Development? Edited by Åge Mariussen, Stockholm 2001. (Nordregio Report 2001:2)

Cruz, S. -TexiERA, A. 2009: The Evolution of the Cluster Literature: Shedding Light on the Regional Studies - Regional Science Debate, Regional Studies, 44 (9): 1263-1288.

Delgado, M., - Porter, M. E., - Stern, S. 2014: Clusters, Convergence, and Economic Performance, Research Policy, 43 (10): 1785-1799.

Dicken, P. - Malmberg, A. 2001: Firms in Territories: A Relational Perspective, Economic Geography, Vol. 77, No. 4 (Oct., 2001), 345-363.

DiCKEN, P. 2011: Global Shift: reshaping the global economic map in the 21st century, 6th edition. London

DiNYA, L. 2008: Szervezetek sikere és válsága. Budapest, Akadémiai Kiadó.

Dobronyi, T. - Halmos, L. - Somosi, É. 2011: Klasztermenedzsment Magyarország, Complex Kiadó Jogi és Üzleti Tartalomszolgáltató Kft. 2011

Doney, P. M. - CANNON J. P. - Mullen M.R. 1998: Understanding the Influence of National Culture on the Development of Trust Academy of Management Review Vol. 23, No. 3.: 601-620.

DöRY, T. 2000: Doktori értekezés A Regionális Innovációs Stratégiák szerepe a területfejlesztésben - a regionális innovációs stratégiák kidolgozásának modellje a Közép-Dunántúli Régió mintáján, Győr-Pécs 2000.

DusEK, T. 1999 A területfejlesztés megújítási iránya, az ipari körzetek. Tér és Társadalom, 13 (1-2): 89-108.

ENRIGHT, M. J. 1996: Regional Clusters and economic development: A research agenda. In U. Straber et al (eds) Business Networks: Prospect for Regional Development, Berlin

ENRIGHT, M. J. 2003: Regional clusters: what we know and what we should know. In: Innovation Clusters and Interregional Competition. SpringerVerlag, Berlin, 99-129.

ETZKOWITZ, H.- LEYDESDORFF, L. 2000: The dynamics of innovation: from National Systems and "Mode 2" to a TripleHelix of university-industry-government relations, Research Policy, 29.:109-123.

EURÓPAi KÖZÖSSÉGEK BizOTTSÁGA 2006: A Bizottság közleménye a Tanácsnak, az Európai Parlamentnek, az Európai Gazdasági és Szociális Bizottságnak és a Régiók Bizottságának, Ismeretek átültetése a gyakorlatba: széles körü innovációs stratégia az Európai Unió számára, $\operatorname{COM}(2006) 502$, http://www.europarl.europa.eu/meetdocs/2004_2009/documents/com/c om_com\%282006\%290502_/com_com\%282006\%290502_hu.pdf

(Letöltve: 2010.01.10.)

EuRÓPAi KÖZÖSSÉGEK BIZOTTSÁGA 2008/A: A Bizottság közleménye a Tanácsnak, az Európai Parlamentnek, az Európai Gazdasági és Szociális Bizottságnak és a Régiók Bizottságának Úton a világszínvonalú klaszterek felé az Európai Unióban: A széles körü innovációs stratégia végrehajtása \{SEK(2008) 2637\} http://eurlex.europa.eu/legal-content/HU/TXT/?uri=CELEX\%3A52008DC0652R\%2801\%29 (Letöltve: 2018.02.26.)

EURÓPAI KÖZÖSSÉGEK BIZOTTSÁGA 2008/B: A BIZOTTSÁG az európai klaszterpolitikai csoport felállításáról (2008/824/EK) 2008.10.30. Az Európai Unió Hivatalos Lapja L 288/7, http://eur-lex.europa.eu/legalcontent/HU/TXT/PDF/?uri=CELEX:32008D0824\&from=EN (Letöltve: 2018.02.26.) 
EUROPEAN COMISSION 2007: Innovative strategies and actions - Results from 15 Years of Regional Experimentation- European Commission Directorate - General Regional Policy,http://ec.europa.eu/regional_policy/archive/funds/2007/innovation/guide_innova tion_en.pdf_(Letöltve 2012.08.11.)

EUROPEAN COMISSION 2017/A: Investing in a smart, innovative and sustainable Industry - A renewed EU Industrial Policy Strategy, http://ec.europa.eu/growth/content/state-union2017-\%E2\%80\%93-industrial-policy-strategy-investing-smart-innovative-andsustainable_en (Letöltve: 2018.02.26.)

EUROPEAN COMISSION 2017/B: White paper on the future of Europe, Reflections and scenarios for the EU27 by $\operatorname{COM}(2017) 2025$ of 1 March 2017, https://ec.europa.eu/commission/sites/beta-

political/files/white_paper_on_the_future_of_europe_en.pdf (Letöltve: 2018.02.26.)

EUROPEAN COMMISSION 2002: Regional Clusters in Europe, Observatory of European SMEs No 3. Enterprise Directorate-General, European Commission, Luxembourg, https://ec.europa.eu/regional_policy/archive/innovation/pdf/library/regional_clusters.pdf , (Letöltve: 2013.08.05.)

EUROPEAN COMMISSION 2003: Final Report of the Expert Group on Enterprise Clusters and Networks. Luxemburg: Enterprise Directorate General, EC, http://ec.europa.eu/growth/content/final-report-expert-group-enterprise-clusters-andnetworks-0_en, (Letöltve: 2013.08.05.)

EUROPEAN COMMISSION 2008: Cluster policy in Europe. A brief summary of cluster policies in 31 European countries. Oxford Research, 2008, Europe Innova Cluster Mapping Project,

http://www.clusterobservatory.eu/system/modules/com.gridnine.opencms.modules.eco/ providers/getpdf.jsp?uid=100146, (Letöltve: 2013.08 .05 .)

EUROPEAN COMMISSION 2010: COMMUNICATION FROM THE COMMISSION, EUROPE 2020 A strategy for smart, sustainable and inclusive growth, $\operatorname{COM}(2010) 2020$, Brussels, 3.3.2010, https://eurlex.europa.eu/LexUriServ/LexUriServ.do?uri=COM:2010:2020:FIN:EN:PDF, (Letöltve: 2019.08.05.)

EUROPEAN COMMISSION 2013: The role of clusters in smart specialisation strategies, https://ec.europa.eu/research/evaluations/pdf/archive/other_reports_studies_and_docum ents/clusters_smart_spec2013.pdf, (Letöltve: 2019.08.05.)

Feser, E. J.,- Bergman, E. M.. 1999: Industrial and Regional Clusters: Concepts and Comparative Applications, Regional Research Institute, West Virginia University, The Web Book of Regional Science. http://www.rri.wvu.edu/WebBook/BergmanFeser/contents.htm

Fujita, M. - Krugman, P. - Venables, A. 2000: The Spatial Economy: Cities, Regions and International Trade. MIT Press, Cambridge, MA.

GambetTA, D. 1988: Can we trust trust? in: Gambetta, D. (Ed.) Trust: Making and breaking cooperative relations. Oxford: Blackwell, 213-238.

GRANOVETTER, M. 2005 The Impact of Social Structure on Economic Outcomes, The Journal of Economic Perspectives, Vol. 19, No. 1 (Winter, 2005), 33-50.

GROsZ, A. - RECHNITZER, J. 2005: Régiók és nagyvárosok innovációs potenciálja Magyarországon. MTA Regionális Kutatások Központja, Pécs-Győr

GRosz, A. 2004: A klaszterorientált fejlesztési politika tapasztalatai Magyarországon. in: Beszteri B. (szerk) Magyarország és a 21. század kihívásai az Európai Unióban; Tanulmánykötet I-II. kötet. 2004, Veszprém: MTA Veszprémi Területi Bizottság, 273288.

GRosz, A. 2005: Klaszteresedés és klaszterorientált politika Magyarországon - potenciális autóipari klaszter az észak-dunántúli térségben. Doktori $(\mathrm{PhD})$ értekezés. Györ-Pécs 
Grosz, A. 2006: Klaszterek és támogatásuk az Európai Unióban és Magyarországon. In: Kihivások és válaszok. A magyar épitőipari vállalkozások lehetőségei az Európai Uniós csatlakozás utáni idöszakban. Szerk.: Lengyel I. - Rechnitzer J. Győr: Novadat Kiadó, 159-187.

High Level Advisory Group on Clusters 2007: The European Cluster Memorandum, Promoting European Innovation Through Clusters, http://www.corallia.org/images/stories/documents/AboutCorallia/AboutCorallia-doc005.pdf, (Letöltve: 2016.06.15.)

Horváth, M. - KeReKes, I. - PATIK, R. 2013: Elemzés a magyar klaszterfejlesztés elmúlt 4 évéröl (tények és tanulságok)

INZELT, A. 1998: Nemzeti innovációs rendszerek. In Inzelt A. (szerk.): Bevezetés az innováció-menedzsmentbe. Müszaki Könyvkiadó, Budapest

IsAKSEN, A. - Hauge, E. 2002: Regional Clusters in Europe. European Commission, Observatory of European SMEs 2002. 3., European Commission Directorate General Enterprise, Luxembourg

IzSAK, K. - Ketels, C. - MeIER ZU KÖCKER, G. - LÄMMER-GAMP, T. 2016: The Smart Guide to Cluster Policy, https://ec.europa.eu/growth/content/smart-guide-cluster-policypublished-0_en (Letöltve: 2017.10.07.)

JuHÁsZ, S. - LENGYEL, B. 2017: Creation and persistence of ties in cluster knowledge networks, Journal of Economic Geography 18 (6): 1203-1226.

KeEBle, D. - Wilkinson, F. 1999: 'Collective learning and knowledge development in the evolution of regional clusters of high technology SMEs in Europe', Regional Studies, 33 (4):295-303.

Keeble, D. - WiLKInSON, F. 2000: High technology SMEs Regional clustering and Collective Learning -in David Keeble and Frank Wilkinson 2000 High Technology Clusters Networking and Collective Learning in Europe, ESRC Centre for Business Research, University of Cambridge, 2000, 1-21.

Kergel, H.- MeIer ZU KöcKeR, G.- Nerger, M. 2014: New Approaches to Improve the Performance of Cluster Management Organisations in Europe, European Secretariat for Cluster Analysis (ESCA) Berlin, https://www.clusteranalysis.org/downloads/Newapproachestoimprove.pdf, (Letöltve: 2017.06.23.)

Ketels, C. - LindQVist, G. - Sölvell, Ö. 2012: EU Cluster Mapping and Strengthening Clusters and Competitiveness in Europe, The Role of Cluster Organisations, The Cluster Observatory, Europa Innova Paper 12, http://publications.europa.eu/resource/cellar/6f14c45f-7d6a-49c7-9bbf785b313657d4.0001.02/DOC_1, (Letöltve: 2017.06.22.)

Ketels, C. - LindQvist, G. - SöLVELl, Ö. 2013: The Cluster Initiative Greenbook 2.0, https://www.clusterportal-

bw.de/downloads/publikation/Publikationen/download/dokument/the-cluster-initiativegreenbook-20/, (Letöltve: 2017.06.20.)

Ketels, C. - SergiY, P. 2014: European Cluster Panorama 2014, European Cluster Observatory http://ec.europa.eu/DocsRoom/documents/7242/attachments/1/translations/en/renditions /pdf, (Letöltve: 2017.06.23.)

Ketels, C. - SergiY, P. 2016: European Cluster Panorama 2016, European Cluster Observatory Report, https://ec.europa.eu/growth/content/european-cluster-panorama2016-published-0_en, (Letöltve: 2017.06.23.)

Ketels, C. 2004: European Clusters, Structural Change in Europe 3 - Innovative City and Business Regions, Hagbarth Publications 2004, https://abclusters.org/wpcontent/uploads/2013/12/Ketels_European_Clusters_20041.pdf, (Letöltve: 2017.06.23.)

KeTELS, C. 2017 Cluster Mapping as a Tool for Development, Institute for Strategy and Competitiveness Harvard Business School 
KLINE S.J. - RosenBERG, N. 1986: An Overview of Innovation, in: Landau-Rosenberg: The Positive Sum Strategy. Harnessing Technology for Economic Growth, National Academy Press, Washington

Kocsis, A. 2012: A multinacionális vállalatok szerepe a hazai klaszterekbe, Vezetéstudomány, XLIII. ÉVF. 2012. KÜLÖNSZÁM

KÖZPONTI STATISZTIKAI HIVATAL - KSH 2013: KUTATÁS-FEJLESZTÉS, 2013

KÖZPONTI STATISZTIKAI HIVATAL - KSH 2017: Kutatás-fejlesztés, 2017

KRUGMAN, P. 1991: Geography and Trade. Cambridge, MA: MIT Press

Krugman, P. 2000: A földrajz szerepe a fejlödésben (The Role of Geography in Development) Tér és Társadalom, 14. évfolyam, 2000/4: 1-21.

Kumar, N. (1996): The Power of Trust in Manufacturer-Retailer Relationships, Harvard Business Review, 74, (6), pp 92-106.

LAGENDIJK, A. 1999: Good practices in SME Cluster initiatives. Lessons from the 'Core' regions and beyond, Centre for Urban and Regional Development Studies, Adapt report

LÄMmER-GAMP, T. - MEIER ZU KÖCKER, G. - NerGER, M. 2014: European Cluster Observatory Report 2014 Cluster Collaboration and Business Support Tools to Facilitate Entrepreneurship, Cross-sectoral Cooperation and Growth, report of the European Cluster Observatory, European Commission, http://ec.europa.eu/DocsRoom/documents/9972/attachments/1/translations/en/renditions /native. (Letöltve: 2017.06.07.)

LÄMMER-GAMP, T.-MEIER ZU KÖCKER, G.-CHRISTENSEN, T. 2011: Clusters are individuals, Creating economic growth through cluster policies for cluster management excellence The Danish Agency for Science, Technology and Innovation, VDI/VDE Innovation + Technik GmbH, Berlin/Copenhagen, https://ec.europa.eu/growth/toolsdatabases/regional-innovation-monitor/news/publication-clusters-are-individual-

$\% \mathrm{E} 2 \% 80 \% 93$-creating-economic-growth-through-cluster-policies-cluster, (Letöltve: 2015.01.22.)

LANE, C. 1998: Introduction: Theories and Issues in the Study of Trust. In: Lan, C. Bachman, R. (eds.) (1998): Trust within and between Organizations, Conceptual Issues and Empirical Applications. Oxford: Oxford University Press, 1-30.

LENGYEL, B. 2005: Triple Helix kapcsolatok a tudásmenedzsment szemszögéből, Buzás N. (szerk.) 2005: Tudásmenedzsment és tudásalapú gazdaságfejlesztés. SZTE Gazdaságtudományi Kar Közleményei 2005. JATEPress, Szeged, 293-311.

LENGYEL, I. - DEÁK, SZ. 2002: Klaszter: a helyi gazdaságfejlesztés egyik sikeres eszköze. Buzás N. - Lengyel I. (szerk.): Ipari parkok fejlödési lehetöségei: regionális gazdaságfejlesztés, innovációs folyamatok és klaszter. SZTE GTK. JATEPress. Szeged. 125-153.

LENGYEL, I. - RECHNITZER, J. 2004: Regionális gazdaságtan. Dialóg Campus, Budapest-Pécs

LENGYEL, I. 2002: A klaszterek fejlesztésének általános tapasztalatai. In Lengyel I. Rechnitzer J. (szerk.) 2002: A hazai épitöipar versenyképességének javitása: klaszterek szerepe a gazdaságfejlesztésben, RégióArt, Györ, 169-190.

LENGYEL, I. 2010: Regionális gazdaságfejlesztés Versenyképesség, klaszterek és alulról szerveződő stratégiák, Akadémia Kiadó, Budapest

LIPPERT, R. 2015: Vezetői szerepek és szervezeti kultúra hatása a klaszterek müködésére, Doktori értekezés, Pannon Egyetem, Veszprém (2015)

Longhi, C. - KeEBLE, D. 2000: High-Technology Clusters and Evolutionary Trends in the 1990s, High-Technology Clusters, David Keeble -Frank Wilkinson, Networking and Collective Learning in Europe, ESRC Centre for Business Research, University of Cambridge, 2000, 21-56.

LONGHI, C. - KeEBle, D. 2000: High-Technology Clusters and Evolutionary Trends in the 1990s, in David Keeble -Frank Wilkinson, High-Technology Clusters, 
Networking and Collective Learning in Europe, ESRC Centre for Business Research, University of Cambridge, 2000, 21-56.

LUKÁCS, A. 2013. A klaszterizációs folyamatok vizsgálata a földrajzi koncentráció, a kritikus tömeg és a finanszírozás összefüggéseiben Magyarországon, Doktori (PhD) értekezés, Nyugat-Magyarországi Egyetem, Sopron

LuKOVICS, M. 2005: Innovációs képesség: a regionális gazdaságfejlesztés alapja. In Buzás N. (szerk.) 2005: Tudásmenedzsment és tudásalapú gazdaságfejlesztés. SZTE Gazdaságtudományi Kar Közleményei. JATEPress, Szeged, 74-86.

Lundvall, B. A - Johnson, B. 1994: The Learning Economy. Journal of Industry Studies, 1: 23-42.

Lundvall, B. A. 1992: National System of Innovation: Towards a Theory of Innovation and Interactive Learning. Printer, London

Marshall, A. 1920: Principles of Economics. Macmillan and Co., Ltd., London.

MARShall, A. 1920: Principles of Economics. Macmillan and Co., Ltd., London.

Martin, R. - Sunley, P. 2001: "Deconstructing Clusters: Chaotic Concept or Policy Panacea?", Revised Version of a Paper Presented at the Regional Studies Association Conference on Regionalising the Knowledge Economy, London, 21 November.

MCCANN, P. 2008: Agglomeration economics. In: Karlsson, C. (ed.) Handbook of research on cluster theory. Edward Elgar, Cheltenham, 23-38.

MeIER ZU KÖCKER, G. - MÜLLER, L. 2015: European Cluster Observatory Report, Cluster Programmes in Europe European Comission, Brussels. https://ec.europa.eu/docsroom/documents/12925/attachments/1/translations/en/rendition s/pdf_(Letöltve: 2017.06.18.)

MenZEL, M.P. - ForNAHL, D. 2007: Working Paper Cluster life cycles: dimensions and rationales of cluster development, Jena Economic Research Papers, 2007 -076: 1-47.

MÉSzÁRos R. 2010. Az információ, az oktatás, a kutatás és fejlesztés, In: Mészáros R. - Boros L., - Nagy, E. - Nagy, G.- Pál, V. A globális gazdaság földrajzi dimenziói, Akadémiai Kiadó, Budapest, 321-331.

MÉSZÁROS, R. 2008. A kibertér, és ami körülötte van, Társadalomföldrajzi megközelítés, JATEpress, Szeged

Miller, P. - Botham, R. - Martin, R. - Moore, B. 2001: Business clusters in the UK: A first assessment. volume 1: Main Report

MÜLlER, L.- LÄMMER-GAMP, T.-MEIER ZU KÖCKER, G.-CHRISTENSEN, T. 2012: Clusters are Individuals, New Findings from the Cluster management and Cluster programme Benchmarking The Danish Ministry of Science Innovation and Higher Education, VDI/VDE-IT GmbH, Berlin/Coppenhagen, https://www.clusteranalysis.org/downloads/ClustersareIndividualsVolumeIIAnnex.pdf, (Letöltve: 2015.01.22.)

NAGY, E. 2009. Európai várospolitikák. Kézirat, MTA RKK, Békéscsaba

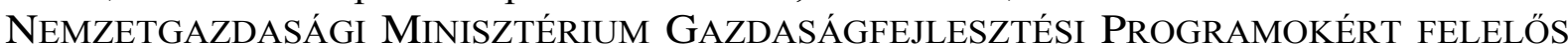
HelyetTES ÁllamtitKÁRSÁG, GFP KSZ NEMZETKÖZI ÉS KLASZTER OSZTÁly 2014: Klaszterfejlesztés 2007-2013 eredmények, http://klaszterfejlesztes.hu/content/cont_5007fe14d8ba95.44814012/eredmenyek.pdf, (Letöltve: 2015.03.10.)

Nerger, M. - LÄMmer-GAMP, T. - MeIER ZU KÖCKER, G. 2014: Cluster Collaboration and Business Support Tools to Facilitate Entrepreneurship, Crosssectoral Collaboration and Growth, European Cluster Observatory Report, https://www.clustercollaboration.eu/euinitiatives/reports/cluster-collaboration-and-business-support-tools,

(Letöltve: 2017.10.06.)

OECD 1999: Managing national innovations systems. Organisation for Economic Cooperation and Development, OECD Publications Service, Paris 
OECD 2005: Oslo Manual. Guidelines for Collecting and Interpreting Innovation Data (3rd edition) OECD, Paris

OECD 2013: Innovation-driven Growth in Regions: The Role of Smart Specialisation

OleKalns, M. - Smith, P. L. 2005: Moments in Time: Metacognition, Trust, and Outcomes in Dyadic Negotiations. Personality and Social Psychology Bulletin, 31, 1696-1707.

PÁL, V.- Boros L. 2010. A globális gazdaság ágazati és területi jellemzői In: Mészáros R. Boros L., - Nagy, E. - Nagy, G.- Pál, V. A globális gazdaság földrajzi dimenziói, Akadémiai Kiadó, Budapest, 123-171.

PATIK, R. - DEÁK, Sz. 2005: Regionális klaszterek feltérképezése a gyakorlatban. Tér és Társadalom, 3 (4): 139-170.

PATIK, R. 2007: A klaszteresedés lehetőségei és vizsgálata a kevésbé fejlett régiókban: példák a Dél-Alföldröl. Doktori (PhD) értekezés. Szegedi Tudományegyetem, Szeged

PINTÉR, R. 2007: Úton az információs társadalom megismerése felé, In. Pintér, R. (szerk.) $A z$ információs társadalom. Gondolat - Új Mandátum, Budapest

PONDS, R.-VAN OORT, F.-FRENKEN, K. 2007: The geographical and institutional proximity of research collaboration, Papers in Regional Science 86 (3): 423-443.

PorTa Novum NonProfit KFT., 2018: Szoftveripari Innovációs Pólus Klaszter Cselekvési és Ütemterve 2018-2020

Porter, M. E. - SÖLVELl, Ö. 1998: The Role of Geography in the Process of Innovation and the Sustainable Competitive Advantage of Firms. In Chandler, A.D - Hagström, P. Sölvell, Ö. (eds.): The Dynamic Firm. Oxford University Press, Oxford, 440-457.

PorTER, M.E. 1990: The Competitive Advantage of Nations. Basic Books, New York

PORTER, M.E. 1998: Clusters and the new economics of competition, Harvard Business Review, 6 (76): 77-90.

PorTER, M.E. 2000: Location, Clusters, and Company Strategy. In Clark, G. L.- Feldman, M. P.-Gertler, M. S. (eds) The Oxford Handbook of Economic Geography. Oxford University Press, 253-274.

Rosenfeld, S. A. 1995: Industrial-Strength Strategies: Regional Business Clusters and Public Policy. The Aspen Institute, Washington DC

SASS, M. - SZANYI, M. 2009: Klaszterek és a multinacionális vállalatok helyi beszállítói hálózatának fejlődése, Európai Tükör, 14 (9): 21-45.

Scarlato, M. - Monni, S. - D'Agostino, G. 2010: Rapporto sui Distretti Technologici (DT): Caratteristiche, confronti internazionali e focus sulle potenzialitá dei DT nell'area di Roma, Università Roma Tre, 2010

SCHUMPETER, J.A. 1912: A gazdasági fejlődés elmélete. Vizsgálódás a vállalkozói profitról, a tőkéről, a hitelről, a kamatról és a konjunktúraciklusról, Közgazdasági és Jogi Könyvkiadó, Budapest

ScOTT, A. J. 1988: New Industrial Spaces. Flexible Production Organization and Regional Development in North America and Western Europe, London: Pion Limited

ScotT, A.J. 1988: New Industrial Spaces. Pion, London.

Sin, L.Y.M., Tse, A.C.B., YAU, O.H.M., ChOW, R.P.M., LEE, J.S.Y., LAU, L.B.Y. (2005): Relationship marketing orientation: scale development and cross-cultural validation, Journal of Business Research 58, 185- 194.

SiNGH, J. 2005: Collaborative networks as determinants of knowledge diffusion patterns. Management Science 51 (5): 756-770.

STORPER, M. 1997: The regional world. Territorial development in a global economy, The Guilford Press, New York, London.

SZABÓ, K. - HÁMORI, B. 2006: Információgazdaság, Akadémia Kiadó, Budapest

SZANYI, M. - CsiZMADIA, P. - IllÉSSY, M. - IWASAKI, I. 2009: A gazdasági tevékenység sürüsödési pontjainak (klaszterek) vizsgálata. Statisztikai Szemle. 87 (9): 1-17.

SZANYI, M. 2008: A versenyképesség javítása együttműködéssel. Regionális klaszterek. Napvilág Kiadó. Budapest, 
Ter Wal, A. L. J.-Boschma, R. 2009: Applying social network analysis in economic geography: framing some key analytic issues. The Annals of Regional Science, 43 (3): 739-756.

Torre, A. - RAllet, A. 2005: Proximity and localization. Regional Studies, 1: 47-60.

TORRE, A. 2008: On the Role Played by Temporary Geographical Proximity in Knowledge Transmission. Regional Studies, 6: 869-889.

TÖDTLING, F. - LEHNER, P. - TRIPPL, M. 2006: Innovation in Knowledge Intensive Industries: The Nature and Geograpy of Knowledge Links. European Planning Studies, 8, 10351058 .

TÖDTLING, F. - TRIPPL, M. 2005: One size fits all? Towards a differentiated policy approach with respect to regional innovation systems, Research Policy, 2005, 34(8): 1203-1219.

TRIPPL, M. - TöDtling, F. 2008: Cluster Renewal in Old Industrial Regions: Continuity or Radical Change? In Karlsson, C. (ed): Handbook of Research on Cluster Theory. Edward Elgar, Cheltenham - Northampton, 203-218.

VAS, Zs. B. 2009: Közelség és regionális klaszterek: A szoftveripar Szegeden, Tér és Társadalom, 23(3): 127-145.

VAS, Zs. B. 2014: Tudásintenzív szektorális innovációs rendszerek a Dél-Alföld régióban Doktori értekezés, Szegedi Tudományegyetem, Szeged, 2014

VILMÁNYI, M. 2011: The relationship performance in the field of university-industrial R\&D cooperation. in Hetesi, E - Kürtösi Zs (ed.): The diversity of research at the Szeged Institute of Business Studies, JATEPress, Szeged, 75-95.

Wise, E. - JOHANSSON, C. 2012: Where the cluster winds are blowing in Europe: Better cluster policies and tools for implementation, TACTICS, VINNOVA. PRO INNO Europe Initiative 2012, https://abclusters.org/wp-content/uploads/2013/12/Where-thecluster-winds-are-blowing-in-Europe.pdf (Letöltve: 2013.02.01.)

WIXTED, B. 2009: Innovation system frontiers (eletronic resource): cluster networks and global value. Springer-Verlag, Berlin Heidelberg

\section{FEJLESZTÉSI DOKUMENTUMOK:}

CSONGRÁD Megye TerÜletFeJlesztési KoncePCIÓJA 2013, http://www.terport.hu/teruletfejlesztes/megyek/fejlesztesi-

dokumentumok/koncepciok/csongrad-megye/csongrad-megye-teruletfe, (Letöltve: 2019. 08.08.)

BÁCS-KISKUN MEgYe TERÜLETFEJLESZTÉSI KONCEPCIÓJA 2013, http://www.terport.hu/teruletfejlesztes/megyek/fejlesztesi-

dokumentumok/koncepciok/bacs-kiskun-megye/bacs\%E2\%80\%93kiskun-megye-ter (Letöltve: 2019.08.08.)

BÉKÉS MEgYe TERÜletFeJleszTÉSI KONCEPCIÓJA 2013, http://www.terport.hu/teruletfejlesztes/megyek/fejlesztesi-

dokumentumok/koncepciok/bekes-megye/bekes-megye-teruletfejleszt, (Letöltve: 2019.08.08.)

NEMZETI FEJLESZTÉSI TERV 2004-2006,

http://www.terport.hu/teruletfejlesztes/orszagos-szint/fejlesztesi-dokumentumok/inemzeti-fejlesztesi-terv-2004-2006, (Letöltve: 2010.08.09.)

NEMZETI INTELLIGENS SZAKOSODÁSI STRATÉGIA 2014, https://nkfih.gov.hu/szakpolitikastrategia/nemzeti-strategiak/nemzeti-intelligens\#, (Letöltve: 2019.07.29.)

PÓLUS KLASZTER KÉZIKÖNYV https://www.palyazat.gov.hu/download.php?objectId=10624_(Letöltve, 2013.03.01.)

SZÉCHENYI TERV 2000

Új MAGYARORSZÁG FeJLESZTÉSI TERV 2007-2013, https://www.palyazat.gov.hu/uj_magyarorszag_fejlesztesi_terv (Letöltve: 2015.02.26.) 


\section{INTERNETES HIVATKOZÁSOK:}

http://www.clusterexcellence.org/background/\#blockyui_3_17_2_60_1488397578257_4432 (Letöltve: 2018.07.15.)

http://www.clusterpolisees3.eu/ClusterpoliSEEPortal/resources/cms/documents/2012.05.22_T he_quality_label_and_indicators_for_cluster_organisations_assessment.pdf (Letöltve: 2018.07.15.)

https://www.palyazat.gov.hu/doc/2916 (Letöltve: 2018.08.08.)

https://www.palyazat.gov.hu/doc/2693 (Letöltve: 2018.08.08.)

https://www.palyazat.gov.hu/ginop-121-16-mikro-kis-s-kzpvllalkozsok-termelsikapacitsainak-bvtse-1 (Letöltve: 2018.08.08.)

https://www.palyazat.gov.hu/ginop-122-16-mikro-kis-s-kzpvllalkozsok-kapacitsbvtberuhzsainak-tmogatsa-1 (Letöltve: 2018.08.08.)

https://www.palyazat.gov.hu/ginop-126-834-16-lelmiszeripari-kzpvllalatok-komplexberuhzsainak-tmogatsa-kombinlt-hiteltermkkel (Letöltve: 2018.08.08.)

https://www.palyazat.gov.hu/doc/4463 (Letöltve: 2018.08.08.)

https://www.palyazat.gov.hu/ginop-133-16-beszllt-mikro-kis-s-kzpvllalkozsok-s-beszlltiintegrtorok-tmogatsa (Letöltve: 2018.08.08.)

https://www.palyazat.gov.hu/ginop-214-15-innovcis-voucher (Letöltve: 2018.08.08.)

https://www.palyazat.gov.hu/doc/4516 (Letöltve: 2018.08.08.)

http://www.klaszterfejlesztes.hu/content.php?cid=cont_4ffc4e93a46377.36499107 (Letöltve: 2018.08.08.) 


\section{KÖSZÖNETNYILVÁNÍTÁS}

Mindenekelőtt szeretném megköszönni a témavezetőmnek Dr. Mészáros Rezső Professzor Úrnak, hogy szakmai tanácsaival és javaslataival segítette a doktori dolgozatom megírását. Töretlen pozitív szemléletével gyakran erőt adott a munkám folytatásához. Köszönetet szeretnék továbbá mondani a Szegedi Tudományegyetem Gazdaság- és Társadalomföldrajz Tanszék vezetőjének, Dr. Kovács Zoltán Professzor Úrnak, hogy lehetőséget biztosított a doktori kutatásom elkészítéséhez és a Tanszék további munkatársainak a doktori tanulmányaim során nyújtott segítségükért.

Szeretném megköszönni Dr. Vas Zsófiának és Dr. Pál Viktornak hasznos észrevételeiket és javaslataikat, amelyekkel elláttak a munkahelyi vita során.

Köszönetemet szeretném kifejezni az interjúalanyaimnak, hogy időt és energiát szántak a kérdéseim megválaszolására és őszinte véleményükkel gazdagították a dolgozatomat.

Köszönöm Keller Péternek a Pénzügyminisztérium, Gazdaságfejlesztési Programok Irányító Hatóságán belül müködő Nemzetközi és Klaszter Osztály főosztályvezető-helyettesének és munkatársainak, hogy adatokat és információkat biztosítottak a doktori dolgozatomhoz és hogy véleményükkel hozzájárultak az elemzésem sikeréhez.

Szeretném megköszönni Dr. Kapás Ferencnek, hogy elindított és támogatott a doktori tanulmányaim során.

Végül, de nem utolsó sorban mérhetetlenül hálás vagyok a családomnak, férjemnek, szüleimnek, testvéremnek és anyósomnak, hogy a nehéz időszakokban is bíztattak és mindig türelemmel voltak hozzám. Támogatásuk és segítségük nélkül ez a disszertáció nem születhetett volna meg. Külön köszönöm kislányomnak, hogy az elmúlt két évben a puszta létével és vidámságával adott erőt a dolgozat befejezéséhez. 
MELLÉKLETEK 


\section{SZ MELLÉKLET}

\section{A DÉL-ALFÖLDI RÉGIÓ KLASZTEREINEK LISTÁJA}

\begin{tabular}{|c|c|c|c|}
\hline Sorszám & Klaszter megnevezése & Székhely & Iparág/szakterület \\
\hline 1 & Kiskun Környezet - Technológiai Klaszter & Kecskemét & $\begin{array}{l}\text { Agrárinnováció, agrár } \\
\text { környezetvédelem }\end{array}$ \\
\hline 2 & Havaria Környezet és Egészségtechnikai Klaszter & Szeged & $\begin{array}{l}\text { Agrárium, } \\
\text { élelmiszeripar, megújuló } \\
\text { energiák }\end{array}$ \\
\hline 3 & Biotechnológiai és Pharmakológiai Innovációs Klaszter & Szeged & Biotechnológia \\
\hline 4 & Dél-Alföldi Biotechnológiai Innovációs Klaszter & Szeged & Biotechnológia \\
\hline 5 & Goodwill Biotechnológiai Klaszter & Szeged & $\begin{array}{l}\text { Biotechnológia, } \\
\text { gyógyszeripar }\end{array}$ \\
\hline 6 & Első Magyar Polgári Biztonságvédelmi Klaszter & Szeged & \begin{tabular}{|l|} 
Biztonság, személy- és \\
vagyonvédelem
\end{tabular} \\
\hline 7 & MADEKO Cipőipari Klaszter & Kiskunmajsa & Cipőipar \\
\hline 8 & 3P Klaszter & Kecskemét & $\begin{array}{l}\text { Csomagolástechnika, } \\
\text { nyomdaipar, } \\
\text { műanyagipar }\end{array}$ \\
\hline 9 & Szent Gellért Egészségügyi Klaszter & Szeged & Egészségipar \\
\hline 10 & $\begin{array}{l}\text { Mosoly-Dél-Alföldi Fogászati-, és Egészségturisztikai } \\
\text { Innovációs Klaszter }\end{array}$ & Kiskunhalas & $\begin{array}{l}\text { Egészségipar, } \\
\text { egészségturizmus }\end{array}$ \\
\hline 11 & Magyar Klinikai Vizsgálati Klaszter & Szeged & $\begin{array}{l}\text { Egészségipar, } \\
\text { gyógyszeripar }\end{array}$ \\
\hline 12 & Békés Megyei Egészségturisztikai Klaszter & Békéscsaba & Egészségipar, turizmus \\
\hline 13 & Hungaromed Klaszter & Szeged & Egészségturizmus \\
\hline 14 & Dél-alföldi Termálklaszter & Gyula & \begin{tabular}{|l|} 
Egészségturizmus, \\
Gyógyturizmus \\
\end{tabular} \\
\hline 15 & Dél-alföldi Helyi Termék és Gazdaságfejlesztő Klaszter & Csorvás & Élelmiszeripar \\
\hline 16 & Hungarikum Élelmiszer és Italgyártó Klaszter & Békéscsaba & Élelmiszeripar \\
\hline 17 & Pharmacofood Klaszter & Szeged & $\begin{array}{l}\text { Élelmiszeripar, } \\
\text { egészségipar }\end{array}$ \\
\hline 18 & Dél-Alföldi Regionális Élelmiszer-lánc biztonsági klaszter & Gyula & $\begin{array}{l}\text { Élelmiszeripar, } \\
\text { mezögazdasági }\end{array}$ \\
\hline 19 & Dél-alföldi Biomassza Hasznosítási klaszter & Szeged & Energetika \\
\hline 20 & Innoenergo-Tec Klaszter & Tótkomlós & Energetika \\
\hline 21 & Dél-alföldi Termálenergetikai Klaszter & Szeged & $\begin{array}{l}\begin{array}{l}\text { Energetika, } \\
\text { termálenergia }\end{array} \\
\end{array}$ \\
\hline 22 & $\begin{array}{l}\text { Építőipari Kockázatmenedzsment és Projekt Controlling } \\
\text { Innovációs Klaszter }\end{array}$ & Szeged & Építőipar \\
\hline 23 & $\begin{array}{l}\text { Építőipari Kutatási, Innovációs és Technológiai-Transzfer } \\
\text { Klaszter (Építő-KITT) }\end{array}$ & Szeged & Építőipar \\
\hline 24 & Könnyüszerkezetes Építőipari Klaszter & Hódmezővásárhely & Építőipar \\
\hline 25 & MIENK Magyar Innovatív Építőipari Nyílt Klaszter & Kecskemét & Építőipar \\
\hline 26 & Ecostep Dél-alföldi Építőipari Klaszter a Fenntartható jövőért & Hódmezővásárhely & Építőipar \\
\hline 27 & Dél-alföldi Regionális Építőipari és Innovációs Klaszter & Kecskemét & Építőipar \\
\hline 28 & $\begin{array}{l}\text { PannonForrás Első Kárpát-medencei Fejlesztési és } \\
\text { Tudásklaszter }\end{array}$ & Békéscsaba & Felnőttképzés \\
\hline 29 & Építőipari technológia-fejlesztési klaszter & Kiskőrös & Gépipar \\
\hline 30 & Gépipari Beszállítói Innovációs Klaszter & Orosháza & Gépipar \\
\hline 31 & Hód Iparos Klaszter & Hódmezővásárhely & Gépipar \\
\hline 32 & Sárrét Metál Klaszter & Szeghalom & gépipar \\
\hline
\end{tabular}




\begin{tabular}{|c|c|c|c|}
\hline Sorszám & Klaszter megnevezése & Székhely & Iparág/szakterület \\
\hline 33 & Dél-alföldi Zöld Gépipari Technológia-fejlesztési Klaszter & Szeged & Gépipar, jármüipar \\
\hline 34 & Gyógyszeriparhoz kapcsolódó logisztikai szolgáltató klaszter & Csongrád & $\begin{array}{l}\text { Gyógyszeripar, } \\
\text { egészségipar }\end{array}$ \\
\hline 35 & Dél-Alföldi Hírközlési és Informatikai Klaszter & Orosháza & $\begin{array}{l}\text { IKT, hírközlés, } \\
\text { informatika }\end{array}$ \\
\hline 36 & Szoftveripari Innovációs Pólus Klaszter & Szeged & Informatika, szoftveripar \\
\hline 37 & Alföldi Regionális Iparfejlesztési Klaszter (AIPA) & Kecskemét & Jármüipar \\
\hline 38 & Hirös Beszállítói Klaszter & Kecskemét & Járműipar, gépipar \\
\hline 39 & Gépjármüroncs-hasznosító klaszter & Kecskemét & Környezetipar \\
\hline 40 & Körösvölgyi Környezettechnológiai Klaszter & Békéscsaba & $\begin{array}{l}\text { Környezetvédelem, } \\
\text { környezettechnológia }\end{array}$ \\
\hline 41 & STEPP Magyar Lézer Klaszter & Szeged & Lézerfizika, fotonika \\
\hline 42 & Dél-alföldi Regionális Logisztikai Klaszter & Csongrád & Logisztika \\
\hline 43 & Dél-alföldi Közlekedésfejlesztési Klaszter & Szeged & $\begin{array}{l}\text { Logisztika, } \\
\text { személyszállítás }\end{array}$ \\
\hline 44 & ArchEnerg Klaszter & Szeged & $\begin{array}{l}\text { Megújuló energia, } \\
\text { építőipar }\end{array}$ \\
\hline 45 & 3D Kreatív Innovációs Klaszter & Mindszent & Szoftverfejlesztés \\
\hline 46 & Zsótér Szolgáltató Klaszter & Szeged & Szolgáltatás \\
\hline 47 & DITAK - Dél-alföldi Innovációs Tanácsadói Klaszter & Szeged & $\begin{array}{l}\text { Tanácsadás, innováció } \\
\text { menedzsment }\end{array}$ \\
\hline 48 & Dél-alföldi Regionális Textilipari Klaszter & Hódmezővásárhely & Textilipar \\
\hline 49 & Rózsa - Dél-alföldi Hungarikum Klaszter & Szeged & $\begin{array}{l}\text { Turizmus, minőségi } \\
\text { magyar termékek }\end{array}$ \\
\hline 50 & Békéscsabai Regionális Turisztikai Klaszter & Békéscsaba & Turizmus \\
\hline 51 & $\begin{array}{l}\text { Kulturális, Tudományos és Üzleti Tartalmak Ökoszisztémája } \\
\text { Innovációs Klaszter }\end{array}$ & Szeged & Oktatás, IKT \\
\hline
\end{tabular}

Forrás: Dél-alföldi Regionális Fejlesztési Ügynökség adatbázisa alapján saját szerkesztés

Kék szín a 2008-ban támogatásban részesített klaszterek Zöld szín a 2011-ben támogatásban részesített klaszterek Piros szín a mindkét évben támogatásban részesített klaszterek 


\section{SZ. MELLÉKLET}

\section{KLASZTERES INTERJÚ VÁZLAT}

\section{Alapadatok}

1.1. klaszter neve:

1.2. a mélyinterjú során megkérdezett személy neve, beosztása:

1.3. a klaszter ágazati irányultsága:

\section{A klaszter összetétele}

2.1. Hol található jelenleg a klaszter székhelye?

2.2. Jelenleg hány tagja van a klaszternek? (esetleg lista a klasztertagokról)

2.3. Hány tag csatlakozott a megalakulás óta? Milyen ütemben? (Volt-e valamilyen nagyobb csatlakozási hullám? pl. akkreditáció előtt vagy után, milyen feltételeknek kell megfelelni a csatlakozóknak?)

Hány tag lépett ki a klaszterből és milyen indokból?

2.4. A klaszter taglétszámhoz viszonyítva mekkora arányú a kis- és középvállalkozások részvétele? Esetleg van-e statisztika a pontos összetételre vonatkozóan?

2.5. A klaszternek tagja-e egyetem, akadémiai kutatóhely, illetve egyéb kutatási intézmény?

2.6. A klaszterben részt vesz-e nagyvállalat, illetve multinacionális vállalat?

2.7. Milyen szerepe van a fenti szervezeteknek? (Domináns, passzív tag, bizonyos területeken befolyásoló tag..stb)

2.8. Van-e/vannak-e úgynevezett vezető cégek a klaszterben? Ha igen, hogyan jelenik meg a vezető szerepük?

2.9. A multinacionális vállalatok, vagy egyetemek jelenléte milyen elönyöket jelent, illetve nehezíti-e a klaszter müködését? (Például döntések elfogadása esetén, klasztervállalások teljesítése...stb.?)

2.10. Mi jellemzi a klasztertagok tevékenységét? Inkább egymást kiegészítő vagy egymással versengő tagok alkotják a klasztert? Amennyiben kiegészítő tevékenységet folytatnak, milyen típusú értékláncot tud kínálni a klaszter?

2.11. Vannak-e szektoron átívelő együttmüködések a klaszterben?

\section{A klaszter földrajzi beágyazottsága, jellemzői}

3.1. A klasztertagok körülbelül hány százaléka müködik a Dél-alföldi Régióban? A Dél-alföldi Régión kívüli tagokkal rendelkezik-e a klaszter? Ha igen, ezek a tagok milyen arányban szerepelnek a klaszterben?

3.2. Mi a jellemző a klaszter tevékenységére földrajzi szempontból? (lokális, regionális, nacionális, transznacionális). 
3.3. Mennyire jellemző a klaszterre a regionális működés? Mennyire épít helyi keresletre a klaszter tevékenysége? Milyen előnyöket jelent a lokalitás? Például helyi képzett humánerőforrás igénybevétele, egyéb erőforrások, kiszolgáló iparágak jelenléte....stb

3.4. Mennyire intenzívek a kapcsolatok a helyi intézményekkel? Egyetem, önkormányzat, egyéb, ha milyen jellegüek ezek a kapcsolatok?

3.5. Rendelkezik-e nemzetközi kapcsolatokkal a klaszter? Ha igen, milyen szervezettel, milyen típusú kapcsolatban áll a klaszter? (kapcsolat más klaszterekkel, kutatási kapcsolat külföldi egyetemekkel, egyéb vállalati kapcsolatok). Ha nem mi lehet az oka (finanszírozás, nyelvtudás, kapcsolatrendszer hiánya...stb.)

3.6. Véleménye szerint földrajzilag kötöttnek vagy területileg rugalmasnak kell lennie egy klaszternek?

\section{Klaszter felépítése, döntéshozatal, kapcsolatok}

4.1. Hogyan épül fel a klaszter szervezetileg (klaszter elnök, klaszter bizottság, klaszter tanács, munkacsoportok, klaszter menedzser)?

4.2. Hány személy dolgozik a klasztermenedzsmentben, napi hány órában, illetve ezen személyek milyen kompetenciákkal bírnak? Inkább klasztermenedzseri tudással vagy szakmai tudással rendelkeznek?

4.3. A klaszter müködtetése inkább informális kapcsolatokon alapul, vagy formalizáltnak tekinthető?

4.4. Milyen gyakran tart a klaszterülést, illetve milyen rendszerességgel találkoznak szervezett formában a tagok?

4.5. A klaszterben milyen az alapító és új tagok közötti viszony? (Az új tagok aktívan be tudnak-e kapcsolódni a munkába?)

4.6. A klasztertagok hány \%-át teszik ki a kevésbé aktív, vagy formális tagok?

4.7. Mekkora szerepe van a klaszterben a személyes kapcsolatoknak és a bizalmi tőkének a működés és az úgynevezett tacit (rejtett) tudás átadása során? Hogyan próbálják meg ezt erősíteni?

4.8. Mennyire alakult ki a klasztertudat a tagokban (1-5-ös skálán értékelve) ezt hogyan próbálják meg klaszterszinten erősíteni?

\section{Klaszter (menedzsment) szolgáltatások}

5.1. A következőkben felsorolunk különböző szolgáltatás-típusokat. A kérdésünk arra irányul, hogy ezen szolgáltatásokat melyikét nyújtja a klasztermenedzsment szervezet a klaszter a tagok részére? Van-e olyan szolgáltatás, amelyet nem a klaszter tagok által befizetett tagdíj ellenében nyújt a klasztermenedzsment szervezet, hanem külön díjazásért?

- $\quad$ rendszeres belső hírlevél

- $\quad$ közös honlap üzemeltetése

- $\quad$ kiállítások, konferenciák szervezése

- tematikus szemináriumok, workshopok a releváns gazdasági és/vagy technikai kérdésekről 
- $\quad$ szakmai klubok, benchmarking klub

- technológiai innovációs menedzsment

- beszállítói kapcsolatok felkutatása, fejlesztése (gyártási kapacitások és üzleti ajánlatok közvetítése)

- $\quad$ adatbázisok összegyüjtése és müködtetése pl: szakágazati $\mathrm{K}+\mathrm{F}$ és egyéb fejlesztési adatbázis, kapcsolódó termelési szolgáltatók adatbázisa, képzési intézmények és képzési programok adatbázisa...stb.)

- $\quad$ szakmai minősítő és továbbképző programok, vállalatközi képzések

- $\quad$ üzletember találkozók szervezése

- projektgenerálás

- piackutatás

- $\quad$ pályázati tanácsadás, pályázatkészítés

- források felkutatása

- $\quad$ lobbi tevékenység

- $\quad$ külföldi kapcsolatépítés

- Egyéb:

5.2. A felsoroltakon kívül nyújt-e egyéb szolgáltatást a tagok részére? Ha, igen mi ez? Tervezi-e a klaszter tevékenységének, szolgáltatás portfóliójának módosítását a jövőben?

5.3. Mi az erössége a klasztermenedzsment szervezetnek, miben kell még fejlődnie?

5.4. Van-e valamilyen értékelési rendszer a klasztermenedzsment tevékenységére vonatkozóan? (Cluster Excellence) Részt vettek-e valamilyen képzésben?

5.5. Mennyire ismeri a klaszter menedzsment a külföldi gyakorlatokat, benchmarkokat?

\section{Klaszter céljai, közös projektek, közös tevékenységek, innováció}

6.1. Mi a klaszter célja, hozzáadott értéke az egyes szereplők számára? Milyen előnyöket tud nyújtani a klasztertagság? (A klasztertagok versenyképességének növelése, $\mathrm{K}+\mathrm{F}$ projektek generálása, Tudástranszfer tevékenységek, nemzetközi együttmüködések elöremozdítása, pályázati források megszerzése)

6.2. Milyen módon tudja a klasztermenedzsment a tagok közötti együttmüködést serkenteni?

6.3. Milyen közös tevékenységek valósultak meg az alábbi területeken, milyen tapasztalatokkal rendelkeznek-e téren?

- Kompetencia- és igényfelmérés a tagok között

- Közös marketing tevékenység

- Közös projektek, fejlesztések megvalósítása

- Közös beruházás, közös eszközbeszerzése

- Közös piaci megjelenés, közös értékesítés

- Nemzetközi projektek

6.4. Kérem, fejtse ki a közös tevékenységek legfőbb jellemzőit, tapasztalatait. 
A közös projektek jellemzően pályázatból vagy akár saját forrásból valósultak meg? Tudna ezekre példát említeni?

6.5. Jellemző-e a gazdasági szereplők és egyetemek, illetve $K+F$ intézetek közötti együttmüködés a klaszterben, melyek a legfontosabb tapasztalatok ezen a területen?

6.6. Innovációt generáló tényezők? Melyek azok az eszközök a klaszteren belül, amelyek segítik az innovációt?

6.7. A klasztertagoknak körülbelül hány \%-a folytat innovációs tevékenységet? ( $\mathrm{K}+\mathrm{F}$ projektek termék, vagy szervezeti innováció, iparjogvédelmi oltalom, szabadalmak, PhD hallgatók foglalkoztatása) Kik az innovációt generáló szervezetek tipikusan?

6.8. A klaszteren belül folyik-e valamilyen innováció, közös $\mathrm{K}+\mathrm{F}$ projekt, ha igen milyen jellegü?

6.9. Start-up cégek szerepe, lehetőségei a klaszterben? Jelen vannak-e induló innovatív start-up cégek a klaszterben? Mennyiben tudja segíteni a klaszter az ő fejlődésüket. El tudja-e képzelni a klaszterben a helyüket és a start-up cégek fejlesztését?

6.10. Az utolsó lapon szereplő innovációt ösztönző tényezők megítélése az innováció szempontjából és a klaszteren belül. Táblázat szerint

\section{A klaszteren belüli kommunikáció}

7.1. A klaszter kommunikációs csatornái közül melyik a domináns: internet, telefon, hagyományos levelezés vagy személyes találkozások?

7.2. Ön elégedett-e a klaszteren belüli kommunikációval, vagy úgy látja, hogy szükséges javítani rajta? (1-5-ig skálán)

7.3. Milyen kommunikáció-fejlesztési lehetőségeket azonosítottak eddig?

7.4. Mennyire jellemző a klaszteren belül az információcsere? (1-5-ig skálán)

7.5. Mennyire tudnak egymástól tanulni az egyes szereplők, mennyire jellemző a kollektív tanulás? A tudásmegosztásnak milyen formái alakultak ki?

\section{A klaszter finanszírozása, támogatása}

8.1. Milyen forrásból finanszírozza a működését a klaszter (tagdíj, pályázati források, hitel, egyéb támogatás...stb)? Ezeknek aránya hogyan alakul?

8.2. Amennyiben az elkövetkező években a klaszter müködtetése uniós forrásokból nem lenne támogatott, miképpen tudja biztosítani a fennmaradását? Hogyan biztosított a hosszú távú pénzügyi fenntarthatóság?

8.3. A nem pénzügyi jellegű támogatások közül melyeket tartaná hasznosnak? (Coaching, közös infrastruktúra biztosítása, kapcsolatépítő események, kommunikációs platformok biztosítása, alacsony kamatozású kölcsönök biztosítása, technológia transzfer, befektető, vagy partnerközvetítés) 


\section{A klaszter teljesítménye}

9.1. Megítélése szerint hogyan alakult a tagok árbevétele, foglalkoztatotti létszáma a megalakulás óta? (Mekkora árbevétel és foglalkoztatotti létszámot fed le a klaszter?)

9.2. Melyek azok a legfontosabb előnyök, szolgáltatások, amelyek elöremozdítják a klasztertagokat a saját fejlődésükben, illetve az együttmüködésben?

9.3. Mi a klaszter erőssége? (erős $\mathrm{kkv}$ bázis, erős $\mathrm{K}+\mathrm{F}$ és innovációs tevékenységek, erős piacvezető cégek, nemzetközi kapcsolatok...stb.)

9.4. Mekkora nagyságrendü támogatást nyertek el a klasztertagok különbözö pályázatokon? A klaszter, illetve a klaszter tagok hány „klaszteres” pályázaton indultak és ebből hány alkalommal nyertek?

9.5. A klaszter a képviselt ágazaton belül milyen pozíciót tölt be, specializálódik-e bizonyos részterületekre, illetve miben rendelkezik versenyelőnnyel, és minek köszönhetően?

9.6. Tudott-e a klaszter szintet lépni a fejlődésében, mikor és mi volt az? Milyen közép és hosszú távú tervekkel rendelkezik a klaszter?

\section{A klaszter célja, jövőképe}

10.1. Az elkövetkező években milyen irányok mentén tud fejlödni a klaszter, melyek a legfontosabb célok?

10.2. Milyen jelentősebb projekteket kíván a klaszter megvalósítani? Milyen finanszírozásból?

10.3. Milyennek látja a klaszterek gazdasági, jogi, pénzügyi környezetét Magyarországon, milyen változtatásokat javasolna? 


\begin{tabular}{|c|c|c|c|c|c|c|c|c|c|c|}
\hline \multirow[t]{2}{*}{ Innovációt ösztönző tényezők } & \multicolumn{5}{|c|}{$\begin{array}{l}\text { A tényező súlya az innováció szempontjából } \\
\text { (véleménye szerint mennyire fontos) } \\
\text { 1: Egyáltalán nem fontos, } 5: \text { Teljes mértékben } \\
\text { fontos }\end{array}$} & \multicolumn{5}{|c|}{$\begin{array}{l}\text { A tényező súlya a klaszteren belül } \\
\text { (mennyire erös a klaszteren belül) } \\
\text { 1: Egyáltalán nem érvényesül, 5: Teljes } \\
\text { mértékben érvényesül }\end{array}$} \\
\hline & 1 & 2 & 3 & 4 & 5 & 1 & 2 & 3 & 4 & 5 \\
\hline \multicolumn{11}{|l|}{ K+F erőforrások és bázis } \\
\hline \multicolumn{11}{|c|}{ Erős egyetemi $\mathrm{K}+\mathrm{F}$ erőforrások és háttér } \\
\hline \multicolumn{11}{|l|}{ Erős vállalati $\mathrm{K}+\mathrm{F}$ háttér } \\
\hline \multicolumn{11}{|c|}{ Erős specializáció valamely területen } \\
\hline \multicolumn{11}{|c|}{ A teljes innovációs értéklánc megjelenése a klaszteren belül } \\
\hline \multicolumn{11}{|l|}{ K+F szolgáltatások } \\
\hline \multicolumn{11}{|c|}{ Innováció menedzsment tevékenység a klaszteren belül } \\
\hline \multicolumn{11}{|c|}{ Külső szolgáltatások könnyebb igénybevétele (pl.technológia transzfer) } \\
\hline \multicolumn{11}{|c|}{ Innovációs források (pályázat, hitel, befektetői tőke) könnyebb elérése } \\
\hline \multicolumn{11}{|c|}{$\begin{array}{l}\text { K+F+I-hez szükséges infrastrukturális vagy humán erőforrások könnyebb } \\
\text { igénybevétele }\end{array}$} \\
\hline \multicolumn{11}{|l|}{ Tudásátadás és kollektív tanulás } \\
\hline \multicolumn{11}{|c|}{ Tudástranszfer tevékenység a tagok között } \\
\hline \multicolumn{11}{|c|}{ A tacit tudás könnyebb átadása a személyes kapcsolat révén } \\
\hline \multicolumn{11}{|c|}{ Kollektív tanulás a klaszteren belül } \\
\hline \multicolumn{11}{|l|}{ Verseny és piacok elérése } \\
\hline \multicolumn{11}{|l|}{ Nemzetközi piacok közös elérése } \\
\hline \multicolumn{11}{|c|}{ Gyorsabb piacra jutás a klaszter segítségével } \\
\hline \multicolumn{11}{|c|}{ A tagok közötti verseny élénkítő hatása } \\
\hline \multicolumn{11}{|c|}{ Együttműködés és kockázatcsökkentés } \\
\hline \multicolumn{11}{|c|}{ A rendelkezésre álló $\mathrm{K}+\mathrm{F}+\mathrm{I}$ erőforrások megosztása } \\
\hline \multicolumn{11}{|c|}{ Egyéni kapcsolatrendszer megosztása } \\
\hline \multicolumn{11}{|c|}{ Interszektoriális együttmüködések a klaszteren belül } \\
\hline \multicolumn{11}{|c|}{ Közös kockázatvállalás a közös projektek révén } \\
\hline Egyéb: & & & & & & & & & & \\
\hline
\end{tabular}




\section{SZ MELLÉKLET}

\section{AZ ELEMZÉSBE BEVONT INTERJÚPARTNEREK LISTÁJA}

\begin{tabular}{|c|c|c|c|c|}
\hline Sorszám & Klaszter neve & $\begin{array}{l}\text { Interjúalany/ok } \\
\text { neve }\end{array}$ & Iparág/szakterület & Alapítás éve \\
\hline 1. & $\begin{array}{l}\text { AIPA (Alföldi Regionális } \\
\text { Iparfejlesztési) Klaszter }\end{array}$ & $\begin{array}{l}\text { Papp Anikó, } \\
\text { Kovács Milán }\end{array}$ & Jármüipar & 2010 \\
\hline 2. & $\begin{array}{l}\text { Archenerg Regionális Megújuló } \\
\text { Energetikai és Építőipari Klaszter }\end{array}$ & Gonda András & $\begin{array}{c}\text { Energetika, megújuló } \\
\text { energiák, építőipar }\end{array}$ & 2007 \\
\hline 3. & $\begin{array}{l}\text { Biotechnológiai és Pharmakológiai } \\
\text { Innovációs Klaszter }\end{array}$ & Ördögh Antal & Biotechnológia & 2011 \\
\hline 4. & $\begin{array}{c}\text { Dél-Alföldi Regionális } \\
\text { Élelmiszerlánc-biztonsági Klaszter }\end{array}$ & Dr. Ábrahám Csaba & $\begin{array}{l}\text { Egészségturizmus, } \\
\text { Gyógyturizmus }\end{array}$ & 2005 \\
\hline 5. & Dél-Alföldi Termál Klaszter & Dr. Alber Andor & Élelmiszeripar & 2008 \\
\hline 6. & $\begin{array}{l}\text { Építöipari Kutatási Innovációs és } \\
\text { Technológia Transzfer Klaszter }\end{array}$ & Volford László & Építőipar & 2011 \\
\hline 7. & Goodwill Biotechnológia Klaszter & Kérdő Balázs & $\begin{array}{l}\text { Biotechnológia, } \\
\text { gyógyszeripar }\end{array}$ & 2007 \\
\hline 8. & $\begin{array}{l}\text { Havaria Környezet- és } \\
\text { Egészségtechnológiai Klaszter }\end{array}$ & Kiss-Mihály Zoltán & $\begin{array}{c}\text { Agrárium, } \\
\text { élelmiszeripar, } \\
\text { megújuló energiák }\end{array}$ & 2006 \\
\hline 9. & Hírös Beszállító Klaszter & Szemerey Szabolcs & Gépipar, autóipar & 2008 \\
\hline 10. & Hód Iparos Klaszter & Gábor Tímea & Gépipar & 2007 \\
\hline 11. & $\begin{array}{l}\text { Körösvölgyi Környezettechnológiai } \\
\text { Klaszter }\end{array}$ & Erdész Béla Sándor & $\begin{array}{c}\text { Környezetipar, } \\
\text { környezettechnológia }\end{array}$ & 2012 \\
\hline 12. & Magyar Klinikai Vizsgálati Klaszter & $\begin{array}{l}\text { Bíró János, } \\
\text { Hársfalvi Péter }\end{array}$ & $\begin{array}{l}\text { Egészségipar, } \\
\text { gyógyszeripar }\end{array}$ & 2010 \\
\hline 13. & $\begin{array}{c}\text { Magyar Innovatív Építőipari Nyílt } \\
\text { Klaszter }\end{array}$ & Steiner Gabriella & Építőipar & 2012 \\
\hline 14. & $\begin{array}{c}\text { Rózsa Dél-alföldi Hungarikum } \\
\text { Klaszter } \\
\end{array}$ & Dr. Kapás Ferenc & $\begin{array}{c}\text { Turizmus, } \\
\text { élelmiszeripar }\end{array}$ & 2005 \\
\hline 15. & Sárrét Metál Klaszter & Fenyvesi László & Gépipar & 2008 \\
\hline 16. & STEPP Klaszter & Maróti Péter & Lézerfizika, fotonika & 2014 \\
\hline 17. & $\begin{array}{l}\text { Szoftveripari Innovációs Pólus } \\
\text { Klaszter }\end{array}$ & $\begin{array}{l}\text { Nagymihály } \\
\text { Krisztina, Csizsár } \\
\text { József, Kónya } \\
\text { Mónika }\end{array}$ & $\begin{array}{l}\text { Informatika, } \\
\text { szoftveripar }\end{array}$ & 2007 \\
\hline 18. & Zsótér Szolgáltató Klaszter & Sándor Edit & $\begin{array}{l}\text { Szolgáltatás, } \\
\text { tanácsadás }\end{array}$ & 2011 \\
\hline 19. & 3D Kreatív Innovációs Klaszter & Dr. Kozma Gergely & Szoftverfejlesztés & 2011 \\
\hline 20. & $\begin{array}{c}\text { 3P Müanyagipari, } \\
\text { Csomagolástechnikai Nyomdaipari } \\
\text { Klaszter }\end{array}$ & $\begin{array}{l}\text { Papp Anikó, } \\
\text { Kovács Milán }\end{array}$ & \begin{tabular}{|c|} 
Múanyagipar, \\
csomagolástechnika, \\
nyomdaipar
\end{tabular} & 2006 \\
\hline
\end{tabular}




\section{SZ. MELLÉKLET}

\section{INTERJÚVÁZLATOK- ESETTANULMÁNY}

\section{Gortva Kónya Mónika klasztermenedzser - Szoftveripari Pólus Innovációs Klaszter}

1. Az alábbi „sikerkritériumok” mennyire érvényesülnek a klaszterben? Néhány szóban kifejtve

- megfelelö összetétel (milyen az összetétel, min lehetne még javitani)

- bizalom

- földrajzi koncentráció

- közös célok valódi együttmüködés, stratégiai gondolkodás

- a profi klasztermenedzsment szervezet

Van-e egyéb tényezö, amelyet fontosnak tart a klaszter szempontjából?

2. A klaszter mekkora hozzáadott értéket képvisel a klasztertagok számára, milyen szolgáltatásokkal és hogyan kívánják ezt erősíteni?

Mit tekint a klaszter a legnagyobb hozzáadott értékének? A tagok felöl mi a visszajelzés? Mik a legfontosabb szolgáltatások? A szolgáltató klaszter koncepció mit takar pontosan?

Mennyire épít a klaszter a lokális elönyökre (önkormányzattal, egyetemmel milyen a kapcsolat)?

A tagok egy értéklánc mentén fejtik ki tevékenységüket vagy inkább versenytársak?

3. A klaszter $\mathrm{K}+\mathrm{F}+\mathrm{I}$ tevékenysége

- Oktatási intézmények, kutatóhelyek részvétele és szerepe a klaszterekben

- Kutatás-fejlesztés és innováció a klasztereken belül (pályázati kimutatás?)

- Tudásmegosztás, tudásátadás a klaszteren belül (föként a közös projektekben)

Mennyire innovativak a tagok, ebben mennyire lehet öket támogatni pl. techshow? A klaszterben a Szoftverfejlesztési Tanszék által sajátságos helyzetben van az egyetem? Milyen az SZTE és a klaszter kapcsolata?

4. Finanszírozás, jövőbeni fenntarthatóság és jövőbeni célok

Hogyan tudja magát fenntartani a klaszter, a támogatási források nélkül mennyire lesz önfenntartó? Milyen bevételekböl fedezi a költségeket? Milyen jövöbeni stratégiai célokkal rendelkezik a klaszter?

5. Nemzetközi trendeknek való megfelelés

Ágazatközi együttmüködések, klaszterközi együttmüködések, nemzetközi kapcsolatok? Nem pénzügyi ösztönzök szerepe? Igénybe vettek-e ilyet, hasznos lenne-e? 


\section{Keller Péter-főosztályvezető-helyettes}

Pénzügyminisztérium Európai Uniós Források Felhasználásáért Felelős Államtitkárság Gazdaságfejlesztési Programok Végrehajtásáért Felelős Helyettes Államtitkárság

GFP Operatív Irányítási Főosztály - Nemzetközi és Klaszter Osztály

1. Az első hipotézisemben azt vizsgálom, hogy az alábbi „sikerkritériumok” mennyire érvényesülnek a Dél-alföldi Régió klasztereiben?

- megfelelö összetétel

- bizalom

- földrajzi koncentráció

- közös célok valódi együttmüködés, stratégiai gondolkodás

- profi klasztermenedzsment szervezet

A fenti szempontok alapján sikeresnek itéli-e meg a klasztereket, kiemelve a Délalföldi Régió klasztereit, esetleg magát az Infopólus klasztert?

Kiemelne néhány szempontot, hogy miért?

Van-e más sikerességi tényezö véleménye szerint? Ha igen mely és miért?

2. A régió klaszterei mekkora hozzáadott értéket képviselnek a klasztertagok számára, milyen szolgáltatásokkal és hogyan kívánják ezt erősíteni?

Mit tekint a klaszterek a legnagyobb hozzáadott értékének?

A klaszterek szolgáltatásai közül mit emelne ki, mi az, ami jól müködik, és mit kell még fejleszteni a nemzetközi példák alapján?

Mely szolgáltatások válhatnak annyira piacképessé, hogy biztositsák a klaszterek fenntarthatóságát? Mivel próbálja a klaszteriroda segiteni ezt a folyamatot (legutóbbi GINOP pályázatok stb.)?

\section{A klaszterek $\mathrm{K}+\mathrm{F}+\mathrm{I}$ tevékenysége}

- Oktatási intézmények, kutatóhelyek részvétele és szerepe a klaszterekben

- Kutatás-fejlesztés és innováció a klasztereken belül

- Tudásmegosztás a klaszteren belül

Mennyire innovatívak a klaszterek, általánosan és a Dél-alföldi Régióban? Ebben mennyire lehet öket támogatni és mivel?

4. Finanszírozás, jövőbeni fenntarthatóság és jövőbeni célok

Hogyan tudják magukat fenntartani a klaszterek a támogatási források nélkül? Mennyire sikerült önfenntartóvá válniuk? Megfelelö célokkal és stratégiával rendelkeznek-e?

5. Nemzetközi trendeknek való megfelelés

Ágazatközi együttmüködések, klaszterközi együttmüködések, nemzetközi kapcsolatok mennyire jellemzöek a hazai és a Dél-alföldi Régió klasztereinél?

Nem pénzügyi ösztönzöknek milyen szerepe van? Ezek mennyire müködnek Magyarországon, mint ,támogatási formák” a klaszterek számára? 


\section{Pitó Enikő - Igazgató - SZTE- Kutatás-fejlesztési és Innovációs Igazgatóság}

1. Az alábbi klaszteres „sikerkritériumok” tekintetében mit tart az egyetem oldaláról fontosnak? Általánosságban és az InfoPólus Klaszter esetében.

- megfelelö összetétel

- bizalom

- földrajzi koncentráció

- közös célok valódi együttmüködés, stratégiai gondolkodás

- a profi klasztermenedzsment szervezet

2. A klaszter hozzáadott értéke, klasztermenedzsment szolgáltatások

Mint klasztertag az egyetem milyen szolgáltatásokat tudna igénybe venni, mi (vagy lenne) az egyetem számára a legnagyobb hozzáadott érték?

Mi az SZTE hozzáadott értéke a klaszterekben, kiemelt tekintettel az Infopólus klaszterre.

3. A klaszter $\mathrm{K}+\mathrm{F}+\mathrm{I}$ tevékenysége

Milyen a $K+F$ együttmüködés az InfoPólus klaszterrel? Más klaszterekkel ezen a területen mennyire aktiv az SZTE?

4. Nemzetközi trendeknek való megfelelés

A nemzetközi klaszteres trendekröl mi a véleménye, mennyiben tud a klaszter megfelelni? A nem pénzügyi ösztönzök szerepéröl mi a véleménye, melyek az igazán fontosak az SZTE szempontjából? 